\author{
UNIVERSIDADE DE SÃO PAULO \\ ESCOLA DE COMUNICAÇÕES E ARTES \\ PROGRAMA DE PÓS-GRADUAÇÃO EM CIÊNCIA DA INFORMAÇÃO
}

LILIAN VIANA

\title{
BIBLIOTECA UNIVERSITÁRIA E FORMAÇÃO CIENTÍFICO-ACADÊMICA MEDIAÇÃO CULTURAL COMO MODELO EPISTÊMICO
}




\section{BIBLIOTECA UNIVERSITÁRIA E FORMAÇÃO CIENTÍFICO-ACADÊMICA MEDIAÇÃO CULTURAL COMO MODELO EPISTÊMICO}

Tese apresentada ao Programa de Pós-graduação em Ciência da Informação da Escola de Comunicações e Artes da Universidade de São Paulo, como requisito para a obtenção do título de Doutora em Ciência da Informação.

Área de concentração: Cultura e informação

Orientadora: Profa. Dra. Ivete Pieruccini

Versão Corrigida

(versão original disponível na Biblioteca da ECA/USP)

São Paulo 
Autorizo a reprodução e divulgação total ou parcial deste trabalho, por qualquer meio convencional ou eletrônico, para fins de estudo e pesquisa, desde que citada a fonte.

Catalogação na Publicação

Serviço de Biblioteca e Documentação

Escola de Comunicações e Artes da Universidade de São Paulo

Dados inseridos pelo(a) autor(a)

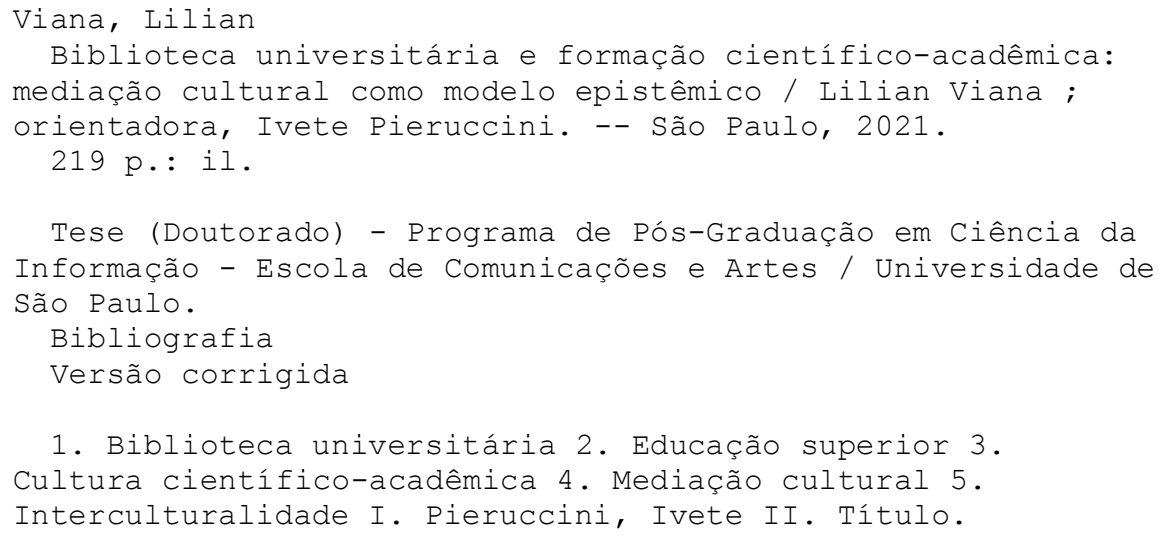

CDD 21.ed. - 020 
VIANA, Lilian

Biblioteca universitária e formação científico-acadêmica: mediação cultural como modelo epistêmico

Tese apresentada à Escola de Comunicações e Artes da Universidade de São Paulo para obtenção do título de Doutora em Ciência da Informação.

Aprovado em:

Banca Examinadora

$\operatorname{Prof}(\mathrm{a}) . \operatorname{Dr}(\mathrm{a})$ : Instituição:

Julgamento: Assinatura:

Prof(a). Dr(a).: Instituição:

Julgamento: Assinatura:

Prof(a). Dr(a).: Instituição:

Julgamento: Assinatura:

Prof(a). $\operatorname{Dr}(a)$ : Instituição: Julgamento: Assinatura:

$\operatorname{Prof(a).~} \operatorname{Dr}(\mathrm{a})$ : Instituição:

Julgamento: Assinatura: 


\section{AGRADECIMENTOS}

À profa. Ivete Pieruccini, mestra que com suas atitudes ensina o rigor, a criticidade, a criatividade, a autonomia intelectual, a gentileza e a acreditar na educação e na ciência como caminhos para construção de um país mais justo.

Ao prof. Edmir Perrotti, por esse encontro intergeracional marcado pela partilha de conhecimento e sabedoria, e por ensinar a importância de que eu me autorize a dizer.

À profa. Lúcia Maciel Barbosa de Oliveira, presença marcante em minha trajetória acadêmica, sempre disposta a contribuir para a ampliação do meu olhar sobre o tema de pesquisa.

À profa. Vânia Mara Alves Lima pelas contribuições no exame de qualificação.

Aos estudantes da disciplina Fundamentos em Biblioteconomia, Documentação e Ciência da Informação que partilharam sua experiência comigo, contribuindo com essa pesquisa.

Aos parceiros do GPEC Amanda, Andreína, Carmem, Fernanda, Léia, Marcos, Pedro, Regina, Silvana, Simone e Solange por constituírem esse espaço de aprendizado e construção de conhecimentos.

Aos parceiros de trabalho na Biblioteca da ECA, especialmente à Marina Macambyra, chefe sempre aberta ao diálogo para que eu pudesse me dedicar à pesquisa e por ser exemplo de bibliotecária para mim.

À Ana Paula Teixeira dos Santos, por me ajudar a construir os sentidos da minha existência e a encarar a pesquisa com curiosidade e interesse nos diversos momentos em que o cansaço se fez presente.

Ao Marcelo Silva Souza, revisor que foi o primeiro leitor desta tese e contribuiu com visadas críticas sobre o texto.

À Stela Madruga, amiga que prontamente me socorreu no momento dos ajustes finais do arquivo da tese.

Ao amigo e professor de português Ricardo Bruno de Oliveira pela disposição em esclarecer minhas inúmeras dúvidas gramaticais e por me apresentar ao conto $\mathrm{O}$ homem da cabeça de papelão.

Aos queridos que fazem da minha vida mais leve, alegre e com aprendizados, sobretudo nesses últimos 4 anos: Carol, Carol Lima, Flora, Guerra, Ligia (minha irmã), Lisandra e Guilherme.

Ao meu pai, Benedito, e minha mãe, Helena por ensinarem a educação como caminho à transformação e por me darem o melhor de si. 
Se o mundo ficar pesado Eu vou pedir emprestado A palavra poesia

Se o mundo emburrecer Eu vou rezar pra chover Palavra sabedoria

Se o mundo andar pra trás

Vou escrever num cartaz A palavra rebeldia

Se a gente desanimar Eu vou colher no pomar A palavra teimosia

Se acontecer afinal De entrar em nosso quintal A palavra tirania

Pegue o tambor e o ganzá Vamos pra rua gritar A palavra utopia.

Samba da Utopia, de Jonathan Silva (2018). 


\section{RESUMO}

VIANA, Lilian. Biblioteca universitária e formação científico-acadêmica: mediação cultural como modelo epistêmico. 2021. Tese (Doutorado em Ciência da Informação) Escola de Comunicações e Artes, Universidade de São Paulo, São Paulo, 2021.

A presente tese trata das relações entre biblioteca universitária brasileira e a problemática da apropriação da cultura científico-acadêmica pelo estudante. Com base em abordagem educativa da biblioteca universitária, a pesquisa propõe a substituição do modelo epistêmico de difusão cultural pelo modelo da mediação cultural, compreendida como categoria articuladora dos sistemas culturais inscritos nos contextos sóciohistóricos do estudante, na ordem cultural científico-acadêmica e em seu patrimônio infodocumental. A opção metodológica incluiu a) análise de discurso (AD) de representações de concepções de biblioteca universitária localizadas na literatura especializada (Biblioteconomia e Ciência da Informação); e b) pesquisa participante com estudantes ingressantes em curso de graduação. Constatou-se que, em grande medida, a biblioteca universitária é atualmente caracterizada a partir de um modelo comunicacional linear de envio de informações a um receptor, um dispositivo técnico e homogeneizante. Considera-se que a representação da biblioteca universitária enquanto lugar de conhecimento, e não para o conhecimento, a coloca como parte essencial dos processos de formação e de significação da cultura científico-acadêmica. Por fim, reivindica-se que a biblioteca universitária configure esferas de intersecção cultural, e seja constituída com vistas à (re)elaboração da experiência do estudante enquanto sujeito do conhecimento, contribuindo para a garantia do direito inato à ciência e cultura.

Palavras-chave: Biblioteca universitária. Educação Superior. Cultura científicoacadêmica. Mediação cultural. Interculturalidade. 


\begin{abstract}
VIANA, Lilian. Biblioteca universitária e formação científico-acadêmica: mediação cultural como modelo epistêmico. 2021. Tese (Doutorado em Ciência da Informação) Escola de Comunicações e Artes, Universidade de São Paulo, São Paulo, 2021.

It deals with the relations between academic library and the problem of the affirmative relation with the scientific-academic culture by the student, in Brazil. Based on the educational approach of the academic library, the research proposes the redefinition of the epistemic model of cultural diffusion that guides conceptions of this device, with a view to that of cultural mediation, understood as an articulating category between different cultural systems - inscribed in the student's socio-historical contexts and in the scientific-academic culture with its infodocumental heritage, respectively. The study applies Discourse Analysis of representations of academic library concepts in Brazilian specialized literature (Information Science and Librarianship) and also participatory research with undergraduate students. As a result, to a large extent, it was found that the academic library is characterized from a linear communicational framework of sending information to a receiver, as a technical and homogenizing device. Besides, the representation of the university library as a place of knowledge - distinct from the idea of a place for knowledge - sets it as a category of the processes of formation and meaning of scientific-academic culture. It is claimed that the academic library constitutes spheres of cultural intersection, developed in order to (re)elaborating the student's experience as a person of knowledge, contributing to the guarantee of his innate right to science and culture.
\end{abstract}

Keywords: Academic library. Higher education. Scientific-academic culture. Cultural mediation. Interculturality. 


\section{LISTA DE SIGLAS}

AD Análise de Discurso

ABNT Associação Brasileira de Normas Técnicas

ALA American Library Association

BDTD Biblioteca Digital de Teses e Dissertações

EaD Ensino a Distância

ECA Escola de Comunicações e Artes

ENANCIB Encontro Nacional de Pesquisa em Ciência da Informação

ENEM Exame Nacional do Ensino Médio

FEBAB Federação Brasileira de Associações de Bibliotecários, Cientistas de Informação e Instituições

IBICT Instituto Brasileiro de Informação em Ciência e Tecnologia

IES Instituições de Ensino Superior

IFLA International Federation of Library Associations and Institutions

PAE Programa de Aperfeiçoamento de Ensino

PISA Programa Internacional de Avaliação de Estudantes

PNBU Programa Nacional de Bibliotecas Universitárias

SciELO Scientific Electronic Library Online

SNBU Seminário Nacional de Bibliotecas Universitárias

TIC Tecnologias de Informação e Comunicação

UNESCO Organização das Nações Unidas para a Educação, a Ciência e a Cultura

USP Universidade de São Paulo 


\section{SUMÁRIO}

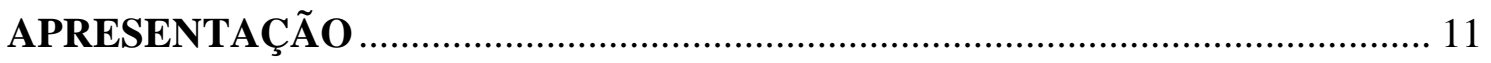

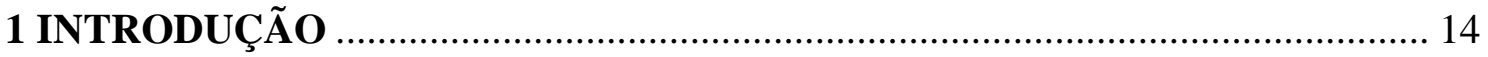

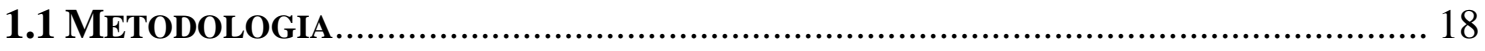

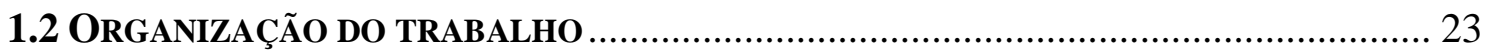

2 NÓS, CONTEMPORÂNEOS? RELAÇÕES COM INFORMAÇÃO E

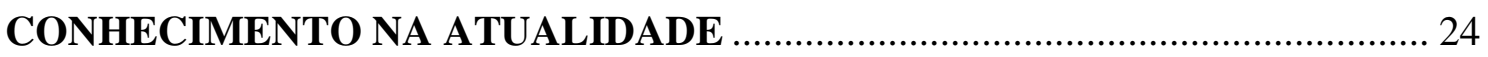

2.1 DINÂMICAS SOCIAIS DA INFORMAÇÃO: CONSUMO E ASSIMILAÇÃO........................ 25

2.2 A ORDEM SIMBÓLICA: INFORMAÇÃO, CONHECIMENTO E ATOS DE SIGNIFICAÇÃO. 29

3 ORDEM SOCIAL DO CONHECIMENTO: BIBLIOTECA UNIVERSITÁRIA E

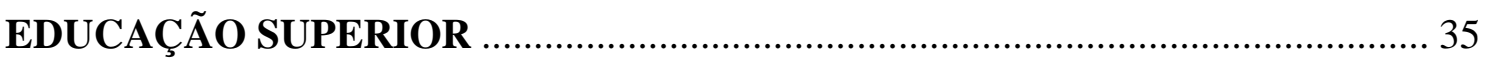

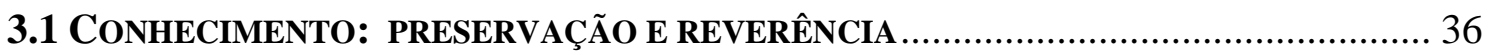

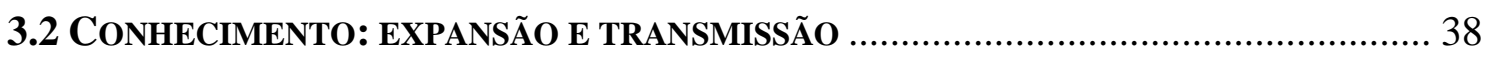

3.2.1 Educação superior no Brasil: o conhecimento útil ........................................ 40

3.2.1.1 A constituição da biblioteca universitária no Brasil ........................................ 48

3.3 CONHECIMENTO: REUNIR, CONTEXTUALIZAR, GLOBALIZAR INFORMAÇÕES E

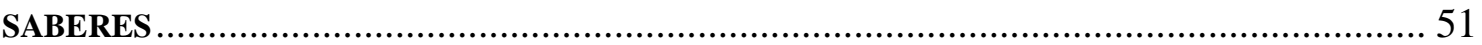

3.3.1 Mediação cultural: uma abordagem para além da prática ............................ 57

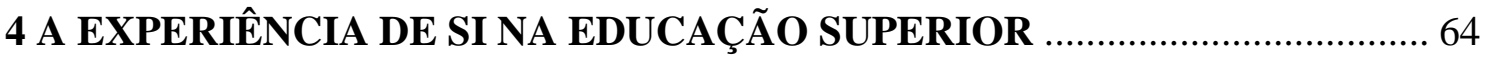

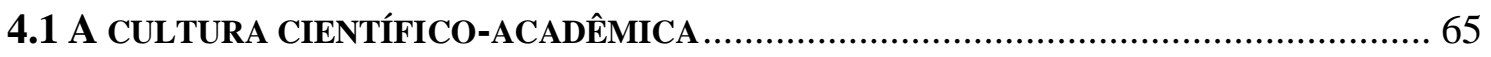

4.2 (RE)ELABORAR A EXPERIÊNCIA DE SI NA CULTURA CIENTÍFICO-ACADÊMICA........ 68

4.2.1 (Re)elaborar-se como forma de pertencimento …......................................... 72

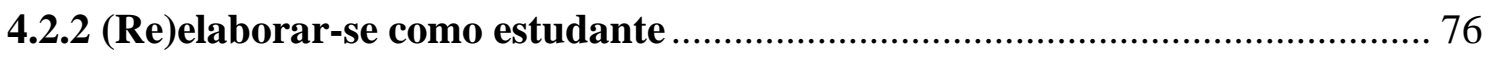

4.2.3 (Re)elaborar-se como alguém dotado de curiosidade epistemológica ............ 81

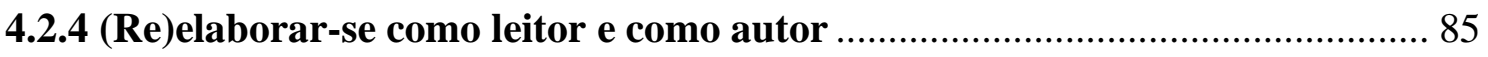

4.3 (RE)ELABORAR ESTRUTURAS DE ACOLHIMENTO E SOCIALIZAÇÃO: O LUGAR DA BIBLIOTECA UNIVERSITÁRIA NA EDUCAÇÃO SUPERIOR ............................................... 94

5 OS SENTIDOS DA BIBLIOTECA UNIVERSITÁRIA ….................................... 100

5.1 (RE)PENSAR A BIBLIOTECA UNIVERSITÁRIA: INDÍCIOS DA EXPERIÊNCIA ............. 100

5.2 DISCURSOS SOBRE BIBLIOTECA UNIVERSITÁRIA: ANÁLISE DE SENTIDOS PRODUZIDOS NO BRASIL A PARTIR DE TEXTOS DO ENANCIB E DO SNBU ..................... 120

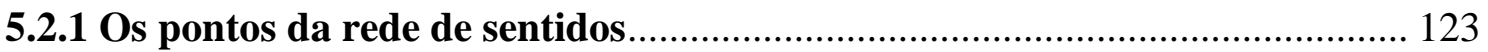

5.2.1.1 Biblioteca universitária sob perspectiva economicista .................................... 123

5.2.1.2 Biblioteca universitária sob o imperativo da sociedade da informação ........... 126

5.2.1.3 Biblioteca universitária sob a perspectiva das funções técnico-especializadas. 127

5.2.1.4 Biblioteca universitária sob perspectiva das TIC ........................................ 130 
5.2.1.5 Biblioteca universitária na perspectiva da comunicação midiática (as mídias sociais digitais)

5.2.1.6 Biblioteca universitária, informação e significação ......................................... 135

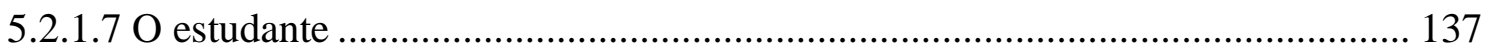

5.2.1.8 Biblioteca universitária e interculturalidade ................................................ 140

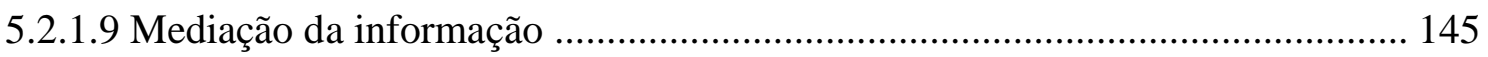

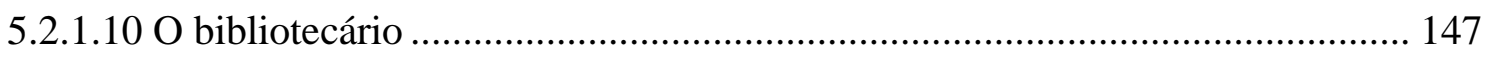

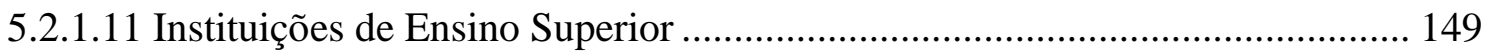

5.2.1.12 O lugar da biblioteca universitária na educação à distância ........................... 151

5.2.1.13 O espaço físico da biblioteca universitária .................................................. 153

5.2.2 Tramando os pontos da rede de sentidos: síntese das representações de

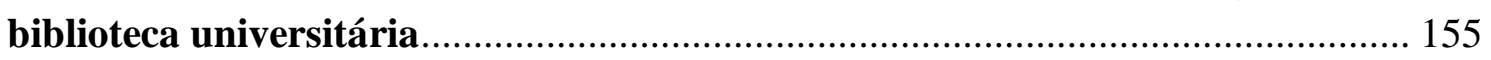

6 BIBLIOTECA UNIVERSITÁRIA NO BRASIL: PELA (RE)ELABORAÇÃO DE MODELOS EPISTÊMICOS NO CONTEXTO DO SÉCULO XXI............... 164

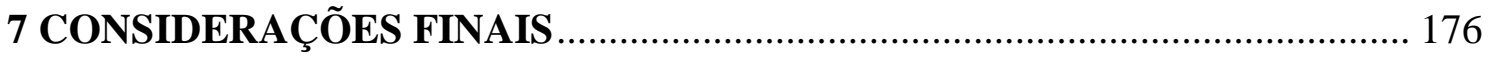

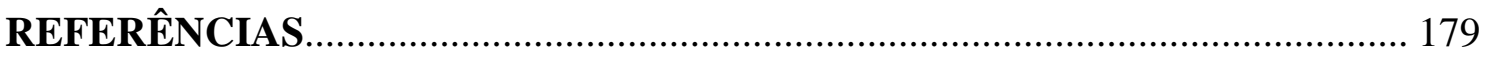

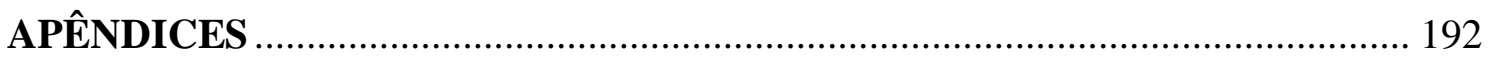

APÊNCIDE A - ROTEIRO DA PESQUISA EMPÍRICA …................................. 192

APÊNDICE B - DELIMITAÇÃO DO PERFIL DOS PARTICIPANTES DA

PESQUISA EMPÍRICA............................................................................ 201

APÊNDICE C - REFERÊNCIAS DE ARTIGOS DO ENANCIB E DO SNBU, DE 2015 A 2019, QUE COMPUSERAM O CORPUS ANALÍTICO ................... 214 


\section{APRESENTAÇÃO}

"Você muda o meio muda você"

Ingressei no curso de graduação em Biblioteconomia na Escola de Comunicações e Artes (ECA) da Universidade de São Paulo (USP) em 2005, ano em que o tema - devidamente estampado em camisetas - da "Semana dos bixos" da ECA foi "Você muda o meio muda você", frase acompanhada da imagem de um lagarto bicolor. A expressão ecoou em mim, sintetizando em uma imagem e poucas palavras o início de uma nova fase em minha vida: a condição de estudante universitária. Ingressar na USP foi adentrar em um novo mundo até então apenas imaginado, que eu conhecia por ouvir falar e por desejar integrá-lo.

Esse novo meio foi sendo descoberto cotidianamente em minha vivência estudantil: pessoas totalmente novas, de origens socioeconômicas diversas; estrutura de aulas distinta daquela que eu conhecia; disciplinas cujos nomes, por si só, me causavam estranhamento e curiosidade; uma relação totalmente nova com o tempo deslocamentos para ir e vir da USP, duração das aulas; a elaboração de trabalhos acadêmicos em estruturas cuja complexidade, em grande medida, eu ignorava fichamentos, sínteses, monografias, etc.; ser convidada a ter voz durante a aula; a quase que ausência de provas e a demanda por trabalhos e textos - ser autora, concatenar ideias; a inquietação com o meu futuro profissional que nessa fase esboçava novos contornos; festas estudantis; clube de esportes; museus; cinemas e bibliotecas. Tais elementos compunham uma nova cultura, com a qual passei a conviver e também a integrar, e da qual, dentro de minhas possibilidades e disponibilidades, busquei apropriar-me.

O término da graduação, com a conquista do diploma de bacharel em Biblioteconomia, configurou um momento de saída da USP. Todavia, o que era esperado dessa intensa experiência de fato ocorreu, a universidade não saiu de mim. A formação recebida incutira-me elementos que me fizeram desejar retornar quando, atuando profissionalmente, deparei-me com novas questões. A complexidade das situações instou-me a buscar compreensões e avanços, dessa vez, por meio do mestrado em Ciência da informação. Um tempo de novos diálogos com o campo científico e de transformações, que foi seguido pelo meu ingresso no quadro funcional dessa 
universidade, na condição de bibliotecária do serviço de referência da Biblioteca da ECA, essa escola que me formou de tantas formas, que afinal me transformou.

$\mathrm{Na}$ nova fase, atuando como bibliotecária em uma das mais prestigiadas universidades brasileiras, comecei a me interrogar sobre minha relação profissional com esse meio e, também, sobre o papel da biblioteca nesse universo. Os questionamentos foram desencadeados pelo meu contato cotidiano com os estudantes, o que evidenciou problemáticas de diferentes ordens, a partir da constatação de que esses jovens, embora tenham acesso a variados dispositivos tecnológicos de informação, em muitos casos mostram-se desprovidos de saberes para se relacionar de forma autônoma e crítica com o universo simbólico de que dispõem. Assim, em minha prática profissional, observei muitos estudantes limitados ao consumo da bibliografia básica para suprir o atendimento às demandas das disciplinas, sem conseguirem realizar incursões mais livres e criativas pelo universo cultural que a universidade disponibiliza, como se eles não tivessem curiosidade sobre o próprio universo que escolheram como seu campo de conhecimento. Ao conversar com estudantes, foi comum constatar que uma grande parcela não teve vivências de biblioteca em sua formação anterior e, não raro, encontrei aqueles que somente entraram em contato com a biblioteca no último ano da graduação, afirmando que a ida à biblioteca se deu em decorrência da obrigatoriedade de realizar a monografia de conclusão de curso. Mas também deparei-me com estudantes que após terem tido esse primeiro contato com a biblioteca, exclamavam, incrédulos, frases como: "Por que eu não vim à biblioteca antes?". Revelando um certo lamento pela ausência de vínculos com esse dispositivo ao longo da formação superior.

Essas observações, decorrentes de minha experiência profissional, fizeram com que eu revisitasse minha trajetória na graduação, tirando daí algumas conclusões que iriam além da esfera pessoal. O primeiro ponto é que a relação com a nova cultura - a científico-acadêmica - demandou de mim novas atitudes, das quais eu era desprovida, embora fossem essenciais para apropriação do novo circuito. O outro ponto é que percebi que as atitudes não estão desvinculadas das questões impostas pelo quadro informacional contemporâneo, marcado por superabundância de signos, em meio aos quais o próprio pensamento pode tornar-se empobrecido, diante da falta de referenciais culturais consistentes, que com o tempo compreendi serem fundamentais ao balizamento das ideias e à construção da capacidade analítica.

Nesse sentido, passei a indagar sobre o papel da educação superior na relação do estudante com a cultura científico-acadêmica e, mais especificamente, qual poderia - ou 
mesmo deveria - ser o papel da biblioteca universitária no processo de criação de condições que permitissem aos estudantes construírem relações com o patrimônio cultural do qual se ocupam. Essa questão foi propulsora da presente pesquisa e o ingresso no doutorado trouxe novos elementos que indicavam a pertinência de um estudo rigoroso sobre essa temática.

Já no doutorado, participar do Programa de Aperfeiçoamento de Ensino (PAE), junto à disciplina Fundamentos em Biblioteconomia, Documentação e Ciência da Informação, possibilitou o contato com estudantes ingressantes no curso de graduação em Biblioteconomia. O acompanhamento das aulas foi um terreno fértil para avançar na confirmação da existência de um quadro problemático, pois observei jovens que ingressam num curso universitário sem terem noções daquilo que desejam ou esperam da área de conhecimento em que estão inseridos. Isto é, para além do desejo de ter uma profissão de nível superior que possa facilitar a ascensão social por meio da obtenção de um melhor emprego e remuneração no futuro.

Esses elementos constitutivos de minha experiência - enquanto estudante de graduação, profissional, "estudante-pesquisadora" - compõem o processo de (trans)formação pelo qual venho passando em minha trajetória. Cada vez mais eles têm me levado a refletir sobre o papel da biblioteca universitária em nossa sociedade e a relevância de ampliação de sua esfera de atuação: para que além da guarda e disponibilização da memória cultural, ela seja caracterizada como um dispositivo de relações críticas e afirmativas entre sujeitos e patrimônio cultural. Tal abordagem contribuiria tanto para melhoria do equilíbrio dos ingressantes e participantes desse universo, quanto para novas abordagens institucionais, já que a inclusão da diversidade cultural que povoa as instituições de educação superior poderia enriquecê-las, efetivamente.

Se por meio da pesquisa científica busco avanços nesse domínio, é por considerar, de um lado, que a (re)elaboração do meio compreende a (re)elaboração do pensamento, e aqui inclui-se minha busca junto à universidade (na graduação e pósgraduação) de condições para me reelaborar. De outro, é porque reconheço que para tanto é preciso interrogar e (re)elaborar instituições que participam da formação do pensamento, dentre as quais estão as universidades e suas bibliotecas. 


\section{INTRODUÇÃO}

O conhecimento é uma construção que compreende processos sociais, políticos e culturais. Fruto da relação de sujeitos com o mundo e seus fenômenos, possibilita ou recusa condições de intervenção no real, manifestando-se no patrimônio simbólico da humanidade (SANTOS, 2009). A produção de conhecimento implica dependência dos sujeitos face ao patrimônio cultural constituído, ou seja, as relações que estabelecem com essa esfera são definidoras do ato de conhecer, bem como do desenvolvimento de sua autonomia intelectual, essencial ao conhecimento enquanto processo crítico e criativo.

Se o conhecimento e o desenvolvimento da autonomia intelectual anunciam uma relação de dependência da esfera simbólica, isso não se resume ao simples encontro com os símbolos. Se para um ser humano saudável basta o contato com o oxigênio para que respire, não se pode dizer que basta o contato com o universo dos signos para que ocorra a apropriação simbólica. Ao desenvolvimento de saberes e atitudes para uma relação crítica e afirmativa nesse circuito, são demandadas múltiplas articulações tanto no âmbito do patrimônio simbólico como no de processos de aprendizagem.

Atualmente as relações entre sujeitos e informações se dão predominantemente num quadro sociocultural marcado por profundas transformações decorrentes das Tecnologias de Informação e Comunicação (TIC) presentes na Internet. Fluxos informacionais hiperacelerados vêm sendo consolidados em meio a modelos comunicacionais delineados sob a perspectiva do consumo simbólico, ditado pelas lógicas do capitalismo global. O quadro implica diretamente os processos de construção de sentidos e, embora nunca antes tenha havido tanta informação, esse volume não corresponde ao aumento do conhecimento, tampouco à socialização de seus processos, sobretudo considerando-se o conhecimento acadêmico ${ }^{1}$, cujos princípios constitutivos

\footnotetext{
1 Utilizamos o termo "conhecimento acadêmico" a partir de Burke (2003), que o emprega para caracterizar as formas dominantes, ou mesmo acadêmicas do conhecimento. O termo é utilizado para caracterizar tanto o conhecimento das Ciências Humanas como das Exatas e Biológicas, e optamos por seu emprego em detrimento do termo "conhecimento científico", pois não encontramos na literatura elementos que sustentassem seu uso em referência ao conhecimento dos diferentes campos apontados. Constatamos que o termo "conhecimento científico" é empregado para definir o conhecimento produzido no âmbito das Ciências Exatas e Biológicas, excluindo-se as Humanidades. As obras seguintes baseiam a nossa opção: Snow (1995) estabelece uma divisão entre o conhecimento científico e aquele das ciências humanas ao afirmar que os estudiosos das humanidades precisavam de contato com o conhecimento científico, do mesmo modo que os cientistas também deveriam ter contato com o conhecimento das
} 
implicam saberes distintos das lógicas que presidem a produção e apropriação de conhecimento do senso comum ${ }^{2}$. Em decorrência, somente o acesso a informações não equivale a condições de produção de conhecimento em contextos acadêmico-científicos.

Aceleração e fragmentação, características implícitas à ordem informacional geral na atualidade, são aspectos igualmente replicados em diferentes circuitos e instâncias produtoras de conhecimento especializado, em suas variadas modalidades. Assim, as Instituições de Ensino Superior (IES) e seus membros não estão imunes a essas dinâmicas.

Num país como o Brasil - marcado por profundas desigualdades socioeconômicas que refletem no precário sistema de educação básica -, assumir que os públicos do ensino superior já estão prontos para relações críticas e afirmativas com a memória cultural que aí circula e é produzida equivale a desconsiderar a fratura existente entre sociedade brasileira e conhecimento acadêmico. Seria recusar condições de possibilidade ao enfrentamento de um problema concreto, que implica a apropriação

Ciências Humanas. Já Albieri (2016, p. 13) afirmou que "em regra, a ideia de conhecimento científico aparece associada fortemente às matemáticas e às ciências naturais". Bachelard (1972, não paginado) delimitou o conhecimento científico como aquele que "quer de início circunscrever seu objeto. Ele vai contra a corrente das vagas generalizações", assim não recorre ao empirismo, pois "o empirismo é a filosofia que convém ao conhecimento comum. O empirismo encontra aí sua raiz, suas provas, seu desenvolvimento. Ao contrário, o conhecimento científico é solidário com o racionalismo e, quer se queira ou não, o racionalismo está ligado à ciência, o racionalismo reclama fins científicos". A definição de Bachelard é acompanhada de exemplos do que seria o conhecimento científico, não contemplando exemplos do conhecimento das Ciências Humanas. De outro lado, Ginzburg (1989) ao discorrer sobre um modelo epistemológico indiciário nas Humanidades nos leva a observar o empirismo como um fazer, por vezes, inscrito nas Humanidades. Com isso, ao articularmos a obra de Ginzburg com a definição de Bachelard, o conhecimento das Ciências Humanas seria excluído do âmbito do "conhecimento científico" A partir disso, optamos pelo emprego do termo "conhecimento acadêmico", portanto, mais amplo que "conhecimento científico", para nos referirmos a esse conhecimento que não é o do senso comum, que foge às vagas generalizações e que, conforme o campo do conhecimento, possui métodos distintos, seja nas Ciências Humanas, Exatas ou Biológicas.

${ }^{2}$ De acordo com Dourado (2016, p. 38) "o senso comum constitui em grande medida uma forma de conhecimento compartilhado socialmente. Permite que o cidadão possa entender e, assim, explicar o mundo que o cerca de forma suficiente para que seja possível viver em sociedade. As opiniões compartilhadas no cotidiano sobre diversos temas sejam eles políticos, sociais e econômicos, não constituem 'opiniões pessoais'. Em grande medida vemos o senso comum como resultado de opiniões compartilhadas, que são aprendidas e reproduzidas no cotidiano de formas diferentes [...]. O senso comum constitui uma forma de conhecimento que carrega algum tipo de lógica. Esta lógica dificilmente permite um entendimento profundo sobre as causas e efeitos das questões que discute. $\mathrm{O}$ princípio do pensamento compartilhado carrega sempre uma lógica explicativa simples e de fácil entendimento que, quando professada a outrem, seja facilmente memorizada e assim compartilhada novamente.[...] De alguma forma, o senso comum constitui um forte empecilho para a construção de conhecimentos e entendimentos mais complexos sobre o real [...]. É importante aqui não confundir senso comum com cultura popular, saber popular e tradições culturais. Nestes casos, independentemente de serem científicas ou não, são saberes que carregam tradições e temperam a diversidade cultural. Desta forma, o senso comum não engloba a situação espontânea de aprendizagem [...] que constitui um conhecimento que acontece espontaneamente, sem uma instrução prévia, mas de forma extremamente rica, extensa e não existe conhecimento acadêmico e escola correspondente a ser proposto". 
do patrimônio infodocumental ${ }^{3}$ da cultura científico-acadêmica pelos estudantes, considerando diferenças e desigualdades constitutivas de suas experiências. Somente uma visão idealizada poderia pressupor que os estudantes chegariam "prontos", ou seja, já formados para se relacionar autônoma e criticamente com essa nova cultura. Essas dimensões não configuram ato natural, advindo do simples encontro do sujeito com o meio, não podendo ser esperadas como inerentes aos que ingressam na educação superior.

Nesses termos, é essencial investigar os dispositivos da cultura científicoacadêmica, mais especificamente a biblioteca na instituição de ensino superior, instância privilegiada de relações do estudante com o patrimônio infodocumental que orienta a educação universitária. Portanto, há que se interrogar em que medida a biblioteca universitária acolhe e socializa os sujeitos nessa cultura. Quais abordagens das interrelações entre os próprios sujeitos e com o patrimônio infodocumental pautam as representações da biblioteca universitária brasileira no século XXI?

Consideramos que, atualmente, no Brasil a biblioteca universitária exerce a função de guarda e oferta de recursos informacionais a serem disponibilizados, privilegiadamente, à comunidade acadêmica, operando como repositório da produção científica local e geral. Na medida em que sua caracterização se dá, majoritária ou exclusivamente, a partir da função informacional, a biblioteca é traduzida como um "centro de comunicação no processo de transferência da informação" (APOSTLE; RAYMOND, 1987, tradução nossa). Assim, seu lugar no ensino superior é de ponto de

${ }^{3} \mathrm{O}$ termo é empregado em referência ao patrimônio cultural organizado e disponibilizado pelas bibliotecas universitárias. A palavra patrimônio é empregada para representar "o que foi sendo legado por todo um tempo e que permanece como uma propriedade" (RIBEIRO, 2007, p. 19). De outro lado, a opção por caracterizar esse patrimônio cultural a partir do termo "infodocumental" se dá em diálogo com Malingre e Serres (2011) - que abordam sua dimensão "info-documentaire" -, por considerarmos que o termo contribui para destacar a especificidade do patrimônio representado nos acervos das bibliotecas, seja em formato físico ou digital. O patrimônio infodocumental é composto por informações produzidas em contextos científicos, artísticos, literários e filosóficos que pressuponham rigor metódico. São informações representativas do conhecimento acadêmico, científico e não daquele do senso comum, sendo que seus contornos constitutivos podem variar conforme os distintos campos do conhecimento. $\mathrm{O}$ patrimônio infodocumental engloba aspectos como a natureza das informações específicas de cada campo do conhecimento, as distintas fontes, os atores, os produtos documentais e as ferramentas de pesquisa. Nesse sentido, inclui as meta-informações. Portanto, com o termo destacamos que a ordem social do conhecimento acadêmico - representada nos acervos das bibliotecas universitárias - possui contornos específicos (que podem variar conforme os campos), diversos daqueles do conhecimento e informação do senso comum. A opção terminológica pela palavra "infodocumental", se deu a partir da junção dos adjetivos informacional e documental, que possibilitou uma classificação mais restrita em detrimento da opção "infodocumentário", já que a palavra documentário, que também é substantivo, poderia remeter o leitor a outro significado. 
acesso ao patrimônio cultural que sistematiza. Sem jamais desconsiderar a importância dessa função, indicamos, contudo, que ela é insuficiente para dar suporte à construção de relações efetivas entre estudantes, informações e conhecimento. Aspecto este que não se resolve somente com oferta tampouco com processos de instrumentalização para o uso competente de informações.

Se a organização e oferta de recursos informacionais, como apoio ao ensino disciplinar ou à pesquisa, são aspectos que fundaram e caracterizam saberes e fazeres essenciais da biblioteca universitária, na contemporaneidade revelam-se outras questões de ordem sócio-histórica que indicam a necessidade de problematizar este modelo, suas lógicas, objetivos e quadros, face aos novos desafios na formação de sujeitos de conhecimento $^{4}$, com autonomia de pensamento e intelectualmente emancipados.

Nesse sentido, mostra-se importante observar o atual modelo de biblioteca universitária em nosso país, indagando-se sobre seus objetivos e metodologias de formação de sujeitos capazes de participar da cultura científico-acadêmica. Ações que objetivem a apropriação da memória cultural, ancoradas em objetivos sociais, educativos e culturais, tendo como princípio norteador a formação de cidadãos e profissionais críticos, são essenciais à ampliação e (re)elaboração do conhecimento acadêmico e, consequentemente, ao desenvolvimento dos domínios sociais, econômicos e culturais de um país.

O debate em causa considera, dentre outros aspectos, a proposição de que a biblioteca universitária, até aqui orientada por modelos epistêmicos que a representam como dispositivo de guarda e acesso a informações especializadas, seja revista a partir de paradigma que privilegie a perspectiva da articulação entre sujeitos e memória cultural, sob o enfoque especial da ordem científica, indispensável ao diálogo com a complexidade do mundo contemporâneo. Trata-se de inserir outra ótica e ética,

\footnotetext{
${ }^{4}$ Referência ao indivíduo que possui estrutura mental, comum aos seres humanos, que lhe permite aprender por meio do estabelecimento de relações. Portanto, as estruturas mentais de estabelecimento de relações culminam no aprendizado. Podendo ser desenvolvidas do começo ao fim da vida do sujeito, elas ocorrem a partir de sua interação com o meio, com os demais e com os saberes. Essas relações possibilitam a construção de níveis cada vez mais complexos de saber e, por sua vez, permitem considerar que, como seres humanos que partilham da mesma estrutura mental, temos as mesmas capacidades, desenvolvidas a partir das relações e interações com aquilo que é externo (FERNANDES, 2010; VASCONCELLOS, 2007). Portanto, à formação do sujeito do conhecimento são ressaltadas as relações que estabelece com o universo simbólico e, consequentemente, consigo mesmo, em perspectiva de produção de sentidos. Ou seja, o sujeito do conhecimento relaciona-se com o universo simbólico em termos da produção de sentidos e não da exclusiva aquisição de conteúdos. Com isso, está em causa alguém que, em sua condição de ser sujeito no mundo, pensa e age sobre a realidade em que vive. (BARROS, 2017).
} 
considerando a perspectiva da mediação cultural como questão que diz respeito à relação entre culturas; a saber, a cultura dos estudantes (e da comunidade acadêmica, de modo geral), o patrimônio infodocumental e os organismos educacionais universitários, categorias mutuamente implicadas nos processos de participação e produção do conhecimento acadêmico.

Em face desse problema, o presente estudo tem como hipótese a ideia de que a biblioteca universitária, ao assentar-se sobre referenciais difusionistas, consolida concepções e configurações que colocam a assimilação de conhecimento e cultura como objeto central da ação; o que enfraquece o conceito de educação como processo de ressignificação do patrimônio infodocumental.

A redefiniçãa do conceito de biblioteca universitária - voltada a processos de formação e socialização na cultura científico-acadêmica -, implica inscrevê-la como dispositivo de apropriação do patrimônio infodocumental.

Desta forma, objetivando o alargamento dos limites conceituais que delimitam as representações da biblioteca universitária, o presente estudo se propõe a contribuir para o desenvolvimento de modelos epistêmicos para a biblioteca universitária brasileira.

A problemática complexa das relações entre estudantes, patrimônio infodocumental e formação universitária será abordada a partir dos seguintes objetivos específicos:

- Analisar representações de biblioteca universitária na literatura brasileira especializada;

- Compreender elementos das dinâmicas socioculturais e educacionais implicados na construção das relações entre estudantes, biblioteca universitária e conhecimento acadêmico.

\subsection{Metodologia}

A pesquisa é constituída a partir dos seguintes eixos interdependentes: 


\section{Pesquisa bibliográfica}

Para abordar as relações entre biblioteca universitária e conhecimento foi realizado levantamento na literatura de distintas áreas do conhecimento a partir dos seguintes conceitos: biblioteca universitária, cultura acadêmica, conhecimento, educação superior, mediação cultural. Muitos são os textos e autores que constituem a trama discursiva desta tese, no entanto, alguns configuram bases a partir das quais consolidamos as estruturas conceituais de pensamento e abordagem do tema de pesquisa. Assim, a problemática da cultura científico-acadêmica foi discutida com base em Caune (2000) e Larrosa (1994); o conceito de conhecimento foi tratado a partir de Burke (2003), Santos (2009) e Charlot (2008). À discussão da educação superior Ribeiro (2014) e Larrosa (1994) constituíram elementos-chave, enquanto a mediação cultural teve por base Caune (2000, 2006), Davallon (2007) Perrotti e Pieruccini (2014).

O levantamento foi realizado a partir dos catálogos e bases de dados disponibilizados pela Universidade de São Paulo (USP), Google e Google acadêmico.

Para depreender representações de biblioteca universitária no Brasil realizamos a análise do discurso de textos publicados nos anais do Encontro Nacional de Pesquisa em Ciência da Informação (ENANCIB) e do Seminário Nacional de Bibliotecas Universitárias (SNBU), no período de 2015 a 2019. A obra de Orlandi (2012) forneceu os referenciais que subsidiaram a aplicação da metodologia da análise dos discursos. As especificações do processo em si estão detalhadas na seção 5.2, na medida em que a análise do discurso se constitui desde a delimitação do recorte de textos à análise dos seus conteúdos. Por esta razão, a opção de reunir as especificações na referida seção, buscou garantir inteligibilidade e rigor às análises.

\section{Pesquisa participante: abordagem do terreno}

Com o objetivo de ampliar nossas compreensões sobre a relação do estudante com o processo de construção de conhecimento foi realizada uma pesquisa empírica, que configurou janela para observações efetivas da questão. Com ela, buscamos depreender elementos que evidenciassem a complexidade que envolve o tema, ampliando nossas perspectivas conceituais acerca da relação entre biblioteca universitária e formação científica do estudante, sem, entretanto, querer indicar que a abordagem do público significasse metodologia de atuação no terreno. Assim, as ações 
desenvolvidas não se caracterizam como ponto de convergência para nossas discussões, mas como elementos propulsores de sensibilização para incursões na literatura. Não estava em causa, por fim, estabelecer categorias teóricas a partir do empírico, mas, tomá-lo como experiência concreta para a observação de questões implicadas na relação do estudante com o patrimônio infodocumental na educação superior.

A opção metodológica da pesquisa participante reuniu a ação da pesquisadora em situações de colaboração concreta com os estudantes, dado que suas manifestações e escolhas foram sendo incorporadas às atividades desenvolvidas. Em outros termos, em se tratando do objetivo de conhecer questões por vezes não explicitadas pelos estudantes, seguir suas demandas mostrou-se um caminho privilegiado para observação de aspectos que envolvem a ordem cultural universitária.

Foi realizado um conjunto de seis ações diversificadas envolvendo pesquisadora e estudantes, entre os meses de abril e junho de 2019. Cada ação incluiu práticas visando ao conhecimento e significação do patrimônio infodocumental e da biblioteca universitária no processo de formação de estudantes de graduação, tendo como foco a sua apropriação. A seguir, trazemos uma descrição em termos gerais das realizações, sendo que o roteiro detalhado das atividades pode ser consultado no Apêndice A.

Fio condutor: As atividades foram desenvolvidas em parceria com a docente da disciplina "Fundamentos em Biblioteconomia, Documentação e Ciência da Informação", ministrada no primeiro semestre letivo do curso de graduação em Biblioteconomia da ECA-USP5 ${ }^{5}$ A demanda de que os estudantes realizassem uma monografia individual como trabalho final da disciplina, o que envolveria desde a escolha de um tema de pesquisa até a redação do trabalho, configurou uma excelente possibilidade para propormos e investigarmos as relações entre estudantes e patrimônio infodocumental. Cabe indicar que a escolha do tema de pesquisa era livre, dentro do escopo da disciplina.

Público: O público constituiu-se do total de 12 estudantes ingressantes no curso de Biblioteconomia no período matutino, em 2019 (o Apêndice B traz a delimitação do

\footnotetext{
${ }^{5}$ A docente é também orientadora desta tese.
} 
perfil dos participantes ${ }^{6}$ ). Após a pesquisadora comparecer a uma aula do curso - que tinha 22 pessoas matriculadas - e apresentar a proposta, estes estudantes demonstraram interesse em participar das atividades, sendo que a taxa de participação ao longo dos encontros sofreu oscilações para baixo ${ }^{7}$. A opção pelos estudantes do matutino ocorreu a partir de observação da professora responsável pela disciplina de que os estudantes desse período, em geral, dispõem de mais tempo livre. A escolha metodológica dos estudantes de Biblioteconomia, de um lado, se deu pela possibilidade de articular o desenvolvimento das ações a uma disciplina obrigatória do curso, o que constituiu fator favorável ao possibilitar interações entre biblioteca e sala de aula. De outro lado, assumimos que seria uma oportunidade de contemplar certos aspectos problemáticos identificados no âmbito das relações entre o estudante universitário, e o par informação/conhecimento. A partir de estudo de Adachi (2017), constatamos que a pontuação para ingresso nesse curso é baixa, sendo prevalente o ingresso de estudantes provenientes de escolas públicas, cuja renda familiar mensal está abaixo da média observada dentre os cursos de Humanas. Esses elementos sinalizaram indicativos de um possível quadro de frágeis relações com o patrimônio cultural, na medida em que exames de avaliação da educação básica brasileira (ver seção 3.2.1) indicam que fraturas na relação com a ordem simbólica se fazem mais presentes entre estudantes da rede pública de ensino.

Local de realização: Biblioteca da ECA-USP, especificamente na Sala de áudio ou Sala de vídeo. A opção metodológica orientou-se pela possibilidade de acolhimento de proposta de experimentação nesta direção, pois a pesquisadora atua como bibliotecária na instituição, sendo que no momento da atividade empírica atuava especificamente no Setor de referência.

\footnotetext{
${ }^{6}$ Os dados que compõem a delimitação do perfil dos participantes são trazidos para que o leitor possa, em alguma medida, ter acesso ao contexto dos estudantes que participaram da pesquisa. Contudo, em nossa tese, os participantes não foram abordados de modo individualizado, considerando questões socioeconômicas e culturais de cada um. Assim, esses dados não foram incorporados às nossas discussões.

${ }^{7}$ A proposta foi apresentada aos estudantes que estavam na sala de aula, contudo, em aula posterior a professora que ministra a disciplina abordou a questão novamente, possibilitando que aqueles que não estavam presentes no encontro anterior soubessem da pesquisa empírica e participassem, em caso de interesse.
} 
Dinâmica das interações: Em decisão conjunta optou-se pela realização de encontros quinzenais no período da tarde. Os seis encontros, com cerca de 2 horas de duração cada, foram delineados a partir dos tópicos: apresentação da proposta e diálogo sobre interesses; o processo de pesquisa: o desejo de conhecer; pesquisar é investigar: a busca significativa; leitura e registro de informações; sínteses de aulas, informação oral, função das referências e citações, referências de recursos audiovisuais; ordenação do pensamento e escrita para se comunicar. Além disso, foi realizado um último encontro para avaliação conjunta do processo, sendo que àqueles que não compareceram foi enviado um questionário online solicitando que preenchessem (para detalhes ver Apêndice A). Nos encontros, as cadeiras da sala eram organizadas em círculo, de modo a proporcionar o contato visual entre os participantes. A pesquisadora atuou como mediadora das interações, buscou o diálogo sobre saberes e fazeres na relação com informação e o conhecimento, instigando os estudantes a falar, debater e refletir sobre sua experiência enquanto estudante e, mais especificamente, sobre a atual experiência de estudante universitário. Havia uma preocupação em dar espaço aos participantes para que se sentissem acolhidos, com suas questões sendo efetivamente escutadas e consideradas. A pesquisadora mostrou-se disponível para conversar com eles em outros momentos, presencialmente - durante o trabalho de bibliotecária no Serviço de referência - ou por meio de e-mail.

Tratamento dos dados: As ações realizadas com os estudantes contaram com gravação em áudio, posteriormente transcrito. Os dados coletados foram trabalhados a partir do registro escrito das falas.

Os resultados: Os elementos desse processo estão tramados especificamente nas seções 4 e 5.1 e, conforme já dito, o foco não foi elaborar uma análise desse processo com os estudantes. Assim, no capítulo 4, em que discutimos a experiência do estudante na educação superior, os achados da pesquisa empírica configuraram uma espécie de chave de abertura, fornecendo elementos que estruturaram nosso pensamento em torno da questão. Nesse capítulo, a pesquisa empírica se revela ao leitor a partir de algumas das falas dos estudantes, indicativas da experiência na educação superior, especificamente no âmbito das relações com informação e conhecimento. Nesse ponto, optamos por apresentar as falas preservando a identidade dos participantes, vinculando-as ao sujeito identificado pelo termo genérico Estudante, singularizado por uma letra (Estudante A, 
Estudante B, etc.). Já na seção 5.1, refletimos sobre o que mobilizou a escolha dos distintos elementos do percurso metodológico, como busca por aprofundamento teórico sobre a relação entre biblioteca universitária e processo do conhecimento.

\subsection{ORgANizAÇÃo DO TRABALHO}

O primeiro capítulo apresenta a atual relação informação/conhecimento no contexto da Internet, a partir da articulação entre a lógica capitalista de produção e consumo material e a esfera da produção simbólica da humanidade.

O segundo capítulo discute a ordem social do conhecimento, abordando especificamente bibliotecas universitárias e IES, evidenciando que seu desenvolvimento ocorre alinhado às representações de conhecimento, transformadas ao longo dos tempos por condições históricas determinadas.

No terceiro capítulo, o objeto é a experiência do estudante universitário, discutida a partir das distâncias simbólicas, via de regra existentes, entre a cultura científico-acadêmica que orienta a educação superior e a cultura dos estudantes, sobretudo no quadro de massificação do ensino superior no país.

O quarto capítulo discute a biblioteca universitária considerando-se indícios da pesquisa participante no que tange à relação do estudante com o patrimônio infodocumental que a constitui. Além disso, elaboramos análise de discurso de textos nacionais, tendo em vista depreender elementos implicados na caracterização da biblioteca universitária no Brasil.

O quinto capítulo discute a biblioteca universitária a partir dos elementos abordados ao longo da tese, evidenciando que suas representações na atualidade se dão, prioritariamente, em viés instrumental, sem incluir criticamente a realidade social, educacional e cultural do país.

As considerações finais condensam sínteses com base na tessitura dos distintos pontos do estudo. 


\title{
2 NÓS, CONTEMPORÂNEOS? RELAÇÕES COM INFORMAÇÃO E CONHECIMENTO NA ATUALIDADE
}

\author{
De certo modo, tudo está no instante, e trata-se de \\ captar sua densidade. (GARCÍA CANCLINI, 2009, p. \\ 219).
}

Contemporâneo é aquele que, para além daquilo que as luzes de seu tempo iluminam, percebe o escuro e suas formas, lançando luzes sobre elas (AGAMBEN, 2010). Dito de outra forma, a partir de Musil (apud LARROSA, 2004, p. 33), para o sujeito contemporâneo "o presente nada mais é do que uma hipótese ainda não superada" e, ao iluminar suas sombras, é capaz de perscrutar novas possibilidades de relação com seu tempo e transformá-lo, colocando-o em relação com outros tempos, lendo a história sob outras lentes. A contemporaneidade não é relação exclusiva com o "aqui" e "agora", mas, também, com as figuras do passado, encarnadas no repertório simbólico elaborado e partilhado pela humanidade.

Vale dizer que é inerente ao sujeito contemporâneo a relação crítica e afirmativa com a ordem simbólica, entendendo-se por relação as vinculações que se dão entre as pessoas, o mundo e seus fenômenos, e que impactam na experiência de vida de cada um.

Em face disso, o questionamento sobre nossa contemporaneidade busca focalizar as relações que estabelecemos com essa ordem, ou seja, construção social delineada e sustentada por diferentes dispositivos, dentre os quais as bibliotecas.

Com base nessa perspectiva, este capítulo argumentará que na atualidade a lógica capitalista de produção e consumo de bens materiais estende-se à esfera da produção simbólica da humanidade. A relação dos sujeitos - daqueles que estão conectados à rede mundial de computadores - com os volumes informacionais, em grande medida se dá num circuito hiperacelerado. Esse sujeito que consome os símbolos do presente, estabelece relação frágil com o patrimônio cultural da humanidade. Nesses termos, se de um lado indicamos uma problemática no âmbito das relações dos sujeitos com a informação, por outro afirmamos ser preciso interrogar as bases teóricas que configuram instituições que participam do processo do conhecimento, dentre as quais a biblioteca universitária. 


\subsection{DINÂMICAS SOCIAIS DA INFORMAÇÃO: CONSUMO E ASSIMILAÇÃO}

Existem três diferentes tipos de informação que impactam nossa espécie: a informação genética do nosso DNA; a informação perceptual, que detectamos com nossos sentidos; e a informação conceitual, que processamos com a nossa mente. Assim, nossa existência é influenciada por duas esferas nas quais tanto a transmissão como a propagação e organização da informação são fundamentais: a bioesfera e a simbolosfera (LOGAN, 2012).

Enquanto seres de significados (BETTELHEIM, 2010), relacionamo-nos com o mundo e seus fenômenos, com os outros e conosco a partir dessa ordem simbólica que nos é externa. Portanto, o ato de significação (BRUNER, 1990) delineia formas de ser, estar e se vincular com o mundo.

Distintos dispositivos participam do processo de sistematização, transmissão e ampliação da simbolosfera, dentre os quais a biblioteca universitária, categoria institucional orientada pela ação de ordenação social do conhecimento acadêmico (BURKE, 2012).

Se, de um lado, essa ordem é socialmente construída com a participação de dispositivos inscritos em contextos históricos determinados, por outro, os processos de relação dos sujeitos com essa ordem também são historicamente delineados. A constatação leva a problematizar as atuais dinâmicas relacionais com o universo simbólico, delineadas pelas TIC, que vêm transformando profundamente a dimensão espaço-temporal da existência humana, sobretudo com a ampliação e intensificação dos usos da internet num contexto de capitalismo global. Segundo Santos (2009), mais que um modo de produção e de trocas comerciais, o modelo capitalista é também regime cultural e civilizacional, estendendo-se para diferentes domínios da vida cotidiana, dentre os quais os modos de relação com o patrimônio simbólico.

Nessa perspectiva, o termo sociedade da informação tem sido empregado para caracterizar a atualidade, evidenciando que o universo sígnico adquire valor de troca no cenário do neocapitalismo sem fronteiras. Muitas vezes, a expressão é intercambiada com "sociedade do conhecimento", como se o conhecimento se desse exclusivamente a partir do acesso às informações (LARROSA, 2015).

Contudo, o termo não está a salvo de críticas já que tanto a ciência como a indústria cultural abarcam um universo limitado da diversidade cultural, sendo deficitárias a participação e a representatividade das diferentes culturas. O amplo 
acesso às informações, por meio das TIC, também não é uma realidade em nosso mundo, marcado por profundas desigualdades sociais. De outro lado, embora os volumes e a qualidade das informações que o sujeito dispõe sejam essenciais para que participe afirmativamente do mundo, por si só, são insuficientes, na medida em que é a partir das suas possibilidades de se relacionar com os repertórios sígnicos de modo crítico, criativo e autônomo que essa condição é alcançada. É possível constatar que, embora a quantidade de indivíduos implicados na produção do conhecimento acadêmico - cientistas, pesquisadores, docentes - seja atualmente muito maior do que em qualquer outro momento da nossa história, esses ainda constituem uma minoria da população, sobretudo, em países com menores índices de desenvolvimento socioeconômico (GARCÍA CANCLINI, 2009).

Portanto, considerar a oferta de signos como algo intrinsecamente bom e suficiente é improcedente para levar a transformações sociais e culturais efetivas. Do mesmo modo, embora aprendizagens informacionais próprias de nosso tempo sejam imprescindíveis, por si só são insuficientes para tal intento. Uma criança, adolescente ou adulto com acesso ilimitado a um computador conectado à internet não irá, necessariamente, explorar diferentes países desse mundo virtual. Na grande maioria dos casos ficará confinado a algumas de suas cidades, sem explorar os diversos caminhos possíveis ou construir novas formas de relação com esse circuito. Para García Canclini (2009), essas não são características exclusivas de pessoas com baixa escolaridade ou desprovidas de quadros conceituais e informações suficientes para selecionar, ordenar e fazer uso dos elementos desse contexto. É inclusive plausível para o autor a hipótese de que a opulência informativa possa justamente potencializar o confinamento cultural (PERROTTI, 1990) em jovens de classes médias e altas. Nesses termos, embora nunca antes tenham sido geradas e postas em circulação tantas informações no mundo, esses volumes não correspondem necessariamente ao aumento da significação, que implica um sujeito capaz de interpretar e elaborar significados.

De outro lado, embora as TIC possibilitem alguma conexão entre nós e certos fenômenos - possibilitando inclusive que as pessoas observem, praticamente em tempo real, situações e fatos que ocorrem a milhares de quilômetros de distância -, são aparatos que configuram um quadro de significação comprometida por parte dos receptores das mensagens. Cabe, então, interrogar até que ponto estabelecemos efetivamente uma relação com a informação recebida que possibilite adentrar em dinâmicas de compreensão e produção de sentidos. Pensemos, por exemplo, na 
quantidade de pessoas que, do conforto de suas casas, assistia às imagens do ataque ao World Trade Center, em Nova Iorque, no dia 11 de setembro de 2001. Ou então, quando sentados no sofá recebemos informações sobre o rompimento da barragem de rejeitos de mineração em Mariana (MG), em 2015, responsável por danos profundos ao meio ambiente brasileiro e ao ecossistema do planeta. Ou ainda, em quantos de nós acompanhamos, a partir de smartphones, as notícias sobre o início, na China, em fins de 2019, daquilo que seria a pandemia causada pelo novo coronavírus. Em que medida o modelo comunicacional em que essas informações se inscrevem cria condições para que os sujeitos adentrem em dinâmicas de produção de sentido e compreensão de fenômenos como o terrorismo, os surtos epidêmicos que se alastram pelo planeta, os crimes ambientais e os impactos destes eventos no mundo em que vivemos?

Para Gumbrecht (2010, p.172), vivemos uma espécie de conectividade deslocada do ato de pensar sobre o mundo, na qual "as imagens flutuantes nas telas que são o nosso mundo transformam-se em barreiras que nos separam para sempre das coisas do mundo". Nessa perspectiva, se assumirmos que assistir virtualmente ao rompimento de uma barragem de rejeitos de mineração consegue, de algum modo, reprimir o nosso pensamento sobre o sentido desse fenômeno, cabe-nos problematizar as instituições que participam do processo do conhecimento, não somente em termos da quantidade de símbolos que disponibilizam, mas dos modos pelos quais atuam a favor dos processos de significação.

De acordo com Han (2017a, 2018), mais comunicação e informação não esclarecem o mundo; os excessos informacionais podem fazer o pensamento definhar em meio à perda da faculdade analítica e de referenciais consistentes que balizem análises. Isto é, a partir de certo ponto a informação já não informa, ao contrário, deforma o próprio pensar, pois os sujeitos têm dificuldades em selecionar, ordenar e fazer uso desses repertórios.

O excesso de estímulos, de informações velozes, também atua sobre a atenção dos sujeitos; vive-se numa hiperaceleração que leva à dispersão. Essa hiperaceleração dos fluxos informacionais tem estabelecido dinâmicas que suprimem o tempo necessário à reflexão pelos sujeitos, num mundo cada vez mais pobre de interrupções. Sem o cultivo do tempo para as interrupções, valoriza-se o sujeito multitarefa, desconsiderando-se, entretanto, tratar-se de alguém de atenção rasa, que não dispõe de tempo e espaço para que algo lhe aconteça ou lhe toque efetivamente na medida em que isto 
[...] requer parar para pensar, parar para olhar, parar para escutar, pensar mais devagar, olhar mais devagar, e escutar mais devagar; parar para sentir, sentir mais devagar, demorar-se nos detalhes, suspender a opinião, suspender o juízo, suspender a vontade, suspender o automatismo da ação, cultivar a atenção e a delicadeza, abrir os olhos e os ouvidos, falar sobre o que nos acontece, aprender a lentidão, escutar aos outros, cultivar a arte do encontro, calar muito, ter paciência e dar-se tempo e espaço (LARROSA, 2002, p. 24).

Essas dinâmicas de interação com o universo simbólico se fazem presentes em diferentes circuitos, incluindo a educação superior. As relações dos estudantes com a informação nos cursos de graduação guardam traços dessa lógica, inadequada para que o estudante universitário experimente a si mesmo como produtor de conhecimento.

O contexto das TIC, sobretudo no domínio das redes sociais digitais delineadas a partir das lógicas do capitalismo global, instiga o sujeito a ser um produtor de signos, mas, não necessariamente de conhecimento. Nas mídias sociais as interações se dão por meio da produção de informações sobre nós mesmos, pela exposição de opiniões sobre as coisas. O tempo livre destinado ao ócio, ao lazer, a comer, a viajar, a permanecer em silêncio, etc., agora é tempo para o trabalho, pois capturados pela estrutura das redes geramos conteúdos - fotos para postar no Instagram, opiniões emitidas no Twitter ou Facebook, um show que assistimos e gravamos para enviar a um grupo no Whatsapp. Nossas vidas são transformadas em produtos e expostas da forma que escolhemos editálas para inseri-las nas redes. Essas grandes empresas de comunicação não precisam gerar conteúdos, nós fazemos isso por elas, somos, simultaneamente, receptores e produtores ativos. Essa natureza de produção, entretanto, não corresponde à ampliação da nossa presença no mundo como sujeitos afirmativos, que criam e se inserem em dinâmicas de transformação. As relações desenvolvidas via TIC, em sua maioria, não implicam a criação do novo, uma vez que a lógica que as anima visa a captura dos sujeitos num movimento de reprodução e aceleração do já existente.

Assim, questões como - O que faço com isso? O que essa informação significa para mim e para o mundo? Como a articulo com meus repertórios para ampliar meu conhecimento? -, embora essenciais à construção do significado das informações, não chegam a constituir a experiência de muitos indivíduos com a ordem simbólica. Essa questão se pronuncia de forma ampla nas sociedades, impactando em diferentes contextos, incluindo o da educação superior e suas bibliotecas, dado que cada vez mais 
as gerações fazem parte dessa cultura tecnológica, que se estabeleceu mais fortemente na entrada dos anos 2000 .

Assim, há que se assumir a existência de um problema quanto ao ato de conhecer, essa prática que, conforme Santos (2009), possibilita ou impede a intervenção no real, e da qual muitos estão à margem. Uma vez que o processo do conhecimento implica relações com o patrimônio simbólico, é essencial que essa dimensão seja rigorosamente considerada no escopo das discussões teóricas em torno da biblioteca universitária, assim como é fundamental problematizar os contornos dessa ordem simbólica socialmente delineada.

A questão é essencial tanto à formação de sujeitos críticos e criadores quanto à própria ampliação do patrimônio cultural da espécie, e traz à tona duas faces interdependentes. De um lado, a imaginação de cada ser, ou como disse Manguel (2015), a "biblioteca imaginária individual", composta por imagens e palavras. De outro, uma "biblioteca imaginária universal", a memória compartilhada por meio da cultura, das gerações, dos povos. Esta é construção coletiva em que o sujeito, a partir de sua capacidade de combinar ideias e símbolos, partilha sua produção, rompendo com o tempo e o espaço (MANGUEL, 2015). A biblioteca imaginária universal alimenta-nos em termos simbólicos, ela nos vincula ao mundo e a outros tempos históricos, mas é também por nós alimentada. Como parte de uma cadeia de elos simbólicos, trata-se de enriquecê-la e ampliá-la em suas fronteiras imateriais pela ação dos sujeitos, a partir de processos de significação. Cabe, então, interrogar em que medida os diferentes dispositivos culturais e educacionais contribuem para que os sujeitos além de fazerem uso desse patrimônio cultural também o enriqueçam. O questionamento, porém, não pode perder de vista diferenças e desigualdades que marcam nosso mundo, já que essa biblioteca é interditada para muitos, assim como certas lógicas estabelecem aquilo que será validado como passível de constituir esse acervo "universal" no qual muitos não se veem representados.

\subsection{A ORDEM SIMBÓLICA: INFORMAÇÃO, CONHECIMENTO E ATOS DE SIGNIFICAÇÃO}

O universo simbólico - a simbolosfera - é inerente a todos os seres humanos, vinculando-nos ao meio e a nós mesmos. Como seres sociais, produzimos e somos produzidos por informações, evidência da necessidade e do desejo humano de 
preservação e continuidade da espécie. Os signos, elementos imateriais que dão base à significação, alimentam a memória, em suas diferentes tipologias (conforme classificado pelas ciências), constituindo urdiduras por meio dos processos de preservação-socialização do pensamento.

A ordem simbólica na contemporaneidade é atravessada, todavia, por novas expressões do pensamento que valem ser distinguidas, face ao objeto de estudo. Nesse sentido, um ponto importante refere-se à distinção entre informação e dados, evidenciando-se a não equivalência entre eles, pois estes "são os fatos puros e simples, sem qualquer estrutura ou organização; os átomos básicos da informação", enquanto a informação "é feita da estruturação de dados, o que adiciona significado aos dados e lhes dá contexto e significância" (LOGAN, 2012, p. 53-54). Ou seja, a informação carrega sentidos e também é aberta à produção de sentidos. Assim, ela compreende um processo que envolve o ser humano, sendo delineada a partir dos contextos nos quais é produzida e utilizada, bem como dos repertórios daqueles que a produzem ou recebem. Portanto, mais que uma coisa, um substantivo, a informação revela-se como um processo diretamente atrelado ao contexto comunicacional no qual se dá e aos atores que nele estão envolvidos. Sob essa abordagem, trata-se de uma construção social, pois são as condições de seu surgimento e os repertórios dos sujeitos envolvidos - seja na criação, transmissão ou recepção -, que constituem a informação. A produção, comunicação e recepção da informação, portanto, não podem ser objeto de simplificações e de reduções que limitem o conceito ao envio de um sinal de um ponto ao outro, como se passássemos batatas por uma esteira, pois conforme Logan (2012, p. 53) "um sinal sem significado não é verdadeiramente informação".

A informação corresponde ao fio de uma trama, o qual revela que entre as informações e os fenômenos há um imbricado universo de formações, conformações e lógicas, elaboradas pelos diferentes atores implicados nesse processo, evidenciando a informação como dispositivo capaz de construir contornos a partir dos quais o real se apresenta. Conforme Hacking (2009) expôs, as informações e seus ordenamentos refazem o mundo real e inventam pessoas, são como trilhas que direcionam e definem nossas relações com o meio e conosco.

O significado da informação se dá, também, a partir da relação que estabelece dentro de uma rede. Uma placa com o nome de uma rua, por exemplo, traz inscrição que dialoga com a cartografia de um bairro, inserido numa cidade, num país. Ao empregar signos, foi possível ao ser humano criar os mapas, o que possibilitou, mesmo 
àqueles que nunca saíram de sua cidade natal, carregar o planeta em suas mãos e conhecê-lo de algum modo, pois, por mais diferentes que sejam os lugares do mundo, nos mapas é estabelecida uma coerência ótica, por meio de uma ordenação (LATOUR, 2008). Desse modo, conhecer o contexto em que se insere a informação é essencial para compreendê-la. O nome de uma rua não diz apenas sobre aquela rua, mas insere-se numa trama maior e explicita que, saber realmente "onde estou?", implica conhecer muito mais do que um único ponto do mapa.

Diante disso, a relação com informações, desconsiderando seu caráter processual, limita as dinâmicas relacionais dos sujeitos na simbolosfera. Ao tomar a informação como um dado - algo neutro, não estruturado - sua complexidade é reduzida, havendo margens para erros e ilusões em meio ao ofuscamento de seu caráter político-ideológico.

Por sua vez, as informações circulam em redes práticas e instituições que ligam o ser humano às situações e aos fenômenos. Um museu, por exemplo, não é uma coleção neutra de conhecimentos. A seleção do que será disposto e os modos de organização, juntando certos objetos, separando outros e colocando alguns em destaque, evidencia que o próprio espaço "fala", ou como afirma Burke (2012, p. 123) "algumas pessoas enviam mensagens a outras por meio da disposição dos objetos", o que se dá a partir de decisões que implicam estratégias discursivas. Assim, as coleções organizadas, seja de bibliotecas, arquivos ou museus não configuram meros meios; os signos e sua própria existência inserem-se nestas instituições, que configuram dispositivos privilegiados no processo de comunicação informacional. Ao sistematizar e disponibilizar o patrimônio infodocumental, a biblioteca universitária participa do processo da informação. Contudo, num país sem cultura de biblioteca como o Brasil, é dispositivo estranho a muitos, seja em termos de suas lógicas informacionais, da sua espacialidade, seja em termos do próprio patrimônio que organiza e disponibiliza, e que é marcado por relações de poder.

Nessa perspectiva, temos que a biblioteca universitária está implicada no conhecimento a partir de duas dimensões: a sistematização da ordem simbólica externa aos sujeitos e, também, os processos de produção de sentidos, a partir das relações dos sujeitos com essa ordem. Assim, a partir de Bruner (1990), a biblioteca compreende um processo mediado que envolve dinâmicas sociais, educacionais e culturais nas quais o sujeito se inscreve como produtor de sentidos. 
O conhecimento, enquanto ação de sujeitos, é uma intervenção contextualizada em termos sociais, políticos e culturais. Para diferenciar conhecimento de informação, podemos ampliar o conceito de conhecimento para que comporte a capacidade de utilizar informações para sair de um estado de dúvida e atingir determinados objetivos, assim, o conhecimento não corresponde a um conteúdo intelectual (JACOB, 2009; LOGAN, 2012; SANTOS, 2009).

O sujeito se lança na ação de conhecer na medida em que acredita que a realidade é composta por elementos passíveis de serem acessados e apreendidos por operações intelectuais. Logo, o conhecimento é pautado pela nossa crença na capacidade do intelecto humano, crença que constitui nossa identidade e subjetividade. O conhecimento é ação de busca por verdades tomadas como ato de criação. Compreende uma certeza cognitiva a qual o sujeito chega - e a partir da qual também avança - na medida em que é elaborada numa relação de abertura com a dúvida, elemento essencial até mesmo para que a prática de conhecer continue a existir. Ou seja, o conhecimento busca verdades, tomadas como criações da espécie humana, as quais comportam o elemento da dúvida, e desse modo, não se confunde com as crenças (um exemplo de crença: Deus existe) (ORTEGA Y GASSET, 2005).

Enquanto processo, o conhecimento pode ser compreendido a partir dos seguintes passos:

- um estágio inicial de certeza no qual o sujeito está;

- um estado posterior de incerteza;

- o desejar um novo estado de coisas, a ser constituído por certeza distinta da certeza inicial (àquela anterior à dúvida);

- o alcançar essa nova certeza que, nascida da dúvida, carrega a dúvida dentro de si (ORTEGA Y GASSET, 2005).

Portanto, surge num cenário de incertezas e desejos de transformar um dado estado de coisas que mobiliza o sujeito para a ação do conhecimento, compreendendo, assim, a transformação de sua relação com o mundo e consigo mesmo.

Na medida em que o conhecimento é produzido e não simplesmente recebido, há que se considerar a cultura como base da sua produção, pois, conforme Geertz (1989, p. 103), ela é “[...] um padrão de significados transmitidos historicamente, incorporado em 
símbolos, um sistema de concepções herdadas, expressas em formas simbólicas" a partir das quais os seres humanos se comunicam, transmitem e desenvolvem seus conhecimentos e atitudes face à vida, configurando, portanto, padrões para o comportamento.

Sendo a cultura "instância simbólica da produção e reprodução da sociedade" (GARCÍA CANCLINI, 2009, p. 45), essencial ao desenvolvimento do conhecimento e aos processos de significação, temos que o conhecimento pressupõe experiência. Ou seja, não há criação sem experiência. Assim, é fundamental engajar criticamente a experiência dos sujeitos no processo de construção do conhecimento, como caminho para a ampliação e reelaboração da experiência consigo e com o mundo, enquanto sujeitos do conhecimento (DELEUZE; GUATTARI, 2000; GIROUX, 1999). Tal abordagem é essencial para que o patrimônio cultural da humanidade seja tomado como alvo de análise, de experimentação e de reelaboração, e não apenas com reverência.

Nessa perspectiva, dispositivos que se configurem como instâncias de relações críticas e criativas com o mundo dos signos, de diálogo entre sujeitos, adquirem importância crescente em nossa época. Pois representam alternativas à sensação contemporânea de esgotamento de tempo e espaço na produção de sentidos; o que tem impactado o desenvolvimento sociocultural das sociedades.

Dinâmicas de relações com a informação que negligenciem os atos de significação e os sentidos atribuídos ao patrimônio simbólico pelos sujeitos desconsideram a importância de sua mobilização para que se vinculem com a memória cultural, para que produzam conhecimento. Descuidar dessa dimensão é incorrer não apenas no risco de empobrecimento da "biblioteca imaginária individual", mas também de empobrecimento da "biblioteca imaginária universal".

Se fecharmos os olhos e nos pusermos a vislumbrar mentalmente uma casa com seus muros, mobília e moradores, e em seguida visualizarmos o momento em que eles abrem as portas e saem de lá em direção a novos cenários, podemos sentir, ao lembrarmos de nossas experiências, como esse deslocamento é rico para esses sujeitos. Isso em razão da relação vital entre o lugar e o ser, que é ampliado em sua presença no mundo ${ }^{8}$ à medida que por ele se desloca e o experimenta. Ao transpor essa imagem para os dispositivos de informação e cultura, como as bibliotecas, talvez possamos imaginar

\footnotetext{
${ }^{8}$ Apropriamo-nos de expressão de Montesquieu (2009). No texto escrito no século XVIII, ao discorrer sobre o gosto Montesquieu expôs a ampliação da esfera de presença da alma (ou do espírito). Em tradução para o português, anunciando a opção, José Teixeira Coelho empregou "ampliar a esfera de presença do ser", expressão aqui adotada.
} 
que neles o sujeito também está habitando uma casa, uma morada simbólica. Pensemos, então, que ele possua as chaves cognitivas, aí entendendo-se também as sensíveis, para abrir as portas e deslocar-se, buscar outros caminhos, outras formas de relação com esse lugar. Talvez ao deixá-lo, depois de longas trajetórias que ampliaram sua presença no mundo, o sujeito sinta-se entediado com seu movimento e busque novas possibilidades de ser e estar nesses caminhos. Quem sabe, então, tenha se apropriado de seu pensamento e se sinta encorajado a criar um movimento próprio, afinado com seu desejo e identidade pondo-se, por exemplo, a dançar. Desenvolver chaves cognitivas que abram as portas simbólicas - que impactem e transformem a sociedade da qual fazemos parte, implica, dentre outros aspectos, interrogar as bases dos processos do conhecimento e suas instituições, o que inclui a biblioteca universitária, uma das possíveis chaves a contribuir para que sejamos contemporâneos de nosso tempo, de nossa história. 


\title{
3 ORDEM SOCIAL DO CONHECIMENTO: BIBLIOTECA UNIVERSITÁRIA E EDUCAÇÃO SUPERIOR
}

\begin{abstract}
O universo (que outros chamam a Biblioteca) compõese de um número indefinido, e talvez infinito, de galerias hexagonais, com vastos poços de ventilação no centro, cercados por balaustradas baixíssimas. De qualquer hexágono, veem-se os andares inferiores $e$ superiores: interminavelmente (BORGES, "A biblioteca de Babel", não paginado, s.d.).
\end{abstract}

O conhecimento acadêmico é construção social que, a partir da imagem de um tripé (BURKE, 2003), tem como suas bases as bibliotecas universitárias, as IES e as disciplinas $^{9}$. As bibliotecas universitárias são caracterizadas, portanto, como instâncias interdependentes das IES, mas, não submissas, todas participando da produção do conhecimento.

Essa perspectiva coloca a biblioteca universitária como categoria estruturante da ordem social do conhecimento, tendo sido delineada em diálogo com as respectivas representações de conhecimento desenvolvidas ao longo da história e que, no âmbito de sua especificidade, ocupa-se da memória cultural caracterizada como científica.

E nesse contexto a dinâmica das representações é significativa, sendo que inicialmente seu desenvolvimento teve por base a ideia de conhecimento como bem simbólico a ser preservado e reverenciado, e posteriormente a ideia de conhecimento como bem a ser expandido e transmitido, tendo em vista o desenvolvimento das sociedades.

Assim, a partir da representação do conhecimento como processo de intervenção ou não no real, que pressupõe reunião, contextualização e globalização de informações e saberes (MORIN, 2010; SANTOS, 2009), interrogamos as atuais representações de biblioteca universitária apontando a necessidade do debate teórico. Com isso, se faz

\footnotetext{
${ }^{9}$ No Brasil esse circuito é marcado por influências europeias e estadunidense. Assim, nossas discussões colocam em causa um conhecimento ocidentalizado que erigiu fronteiras, deixando à margem outros modos de conhecer, delimitando a partir de lógicas específicas aquilo que poderia ou não ser considerado conhecimento. Não deixamos de considerar esse jogo de luz e sombra, entretanto, problematizar as instituições de educação superior no Brasil e suas bibliotecas significou observar essa esfera institucionalizada de relação com o conhecimento que, ao preservar e produzir certos conhecimentos, também apaga e suprime tantos outros.
} 
necessário o desenvolvimento de modelo epistêmico para a biblioteca universitária alinhada a tal concepção, o que implica, portanto, considerar o estudante como sujeito de significados do processo do conhecimento.

\subsection{CONHECIMENTO: PRESERVAÇÃo E REVERÊNCIA}

O ser humano elabora significados a partir da interação com o que o circunda, forjando uma interpretação tanto do mundo como de sua interação com ele, sendo que a maior parte de suas convicções e ideias não são por ele construídas, mas herdadas de seu meio histórico (ORTEGA Y GASSET, 1946).

Desta forma, nossa relação com o patrimônio simbólico é uma relação social. O sujeito aprende a ser humano, pertencente à sua espécie a partir de inter-relações simbólicas; apenas a materialidade da esfera biológica - do que a natureza física lhe oferece - não permitiria ao ser humano alcançar sua condição humana, de ser simbólico.

Para a compreensão desse quadro teórico são importantes alguns aspectos fundantes da história social do conhecimento ocidental e ocidentalizado, que afetam o desenvolvimento das IES e das bibliotecas universitárias no Brasil.

$\mathrm{Na}$ Idade Média o conhecimento era fortemente atrelado à Igreja Católica, responsável por universidades constituídas, em sua maioria, por membros do clero tanto no corpo docente como discente. Embora relativamente nova, a universidade compunha uma instituição bastante antiga, a Igreja, detentora do domínio hegemônico sobre a vida cultural e educacional das pessoas, numa Europa medieval em que os próprios governantes dependiam do chefe religioso local ou então do Papa (BURKE, 2003; SANTOS FILHO, 2007).

A partir do século XII, fins da Idade Média, dá-se o surgimento de cidades e universidades de maneira simultânea, num momento em que a noção de cidade carregava consigo a necessidade de formar pessoas conforme determinada cultura. Nesse contexto, as universidades separam-se das Igrejas e passam ao domínio do Estado, em meio a um processo de desvinculação do poder entre Coroa e a Cruz (BURKE, 2003).

Nesse período (1200 a 1450) a função da universidade era transmitir o conhecimento constituído: aos docentes cabia replicá-lo e aos discentes, assimilá-lo, não cabendo, a ambos, interpretações ou reflexões acerca de um conhecimento tido como 
consagrado, que fora estabelecido por grandes pensadores e filósofos (BURKE, 2003). Uma noção de autoridade vinculava-se ao conhecimento, tomado como verdade irrefutável fechada em si mesma e que não deixava margens para o diálogo. Trata-se de período em que as universidades não estavam voltadas a ensinar a pensar, a formar pessoas para produzir conhecimentos novos ou destoantes. Sua missão era transmitir significados, preservando uma cultura estabelecida e nela inserindo os sujeitos enquanto seus reprodutores.

As disciplinas então estudadas na universidade, ao menos oficialmente, eram fixas e compunham as chamadas sete artes liberais - gramática, retórica, dialética, aritmética, geometria, astronomia e música -, e os três cursos de Direito, Teologia e Medicina (BURKE, 2003; SANTOS FILHO, 2007). As disciplinas que agrupavam os conhecimentos transmitidos explicitam a forma pela qual a sociedade da época construía e ordenava representações do mundo e seus fenômenos, estabelecendo, assim o próprio pensamento e delineando as relações das pessoas com o mundo, com os outros e consigo mesmas.

As bibliotecas universitárias inscrevem-se nesse circuito como dispositivos ${ }^{10} \mathrm{de}$ preservação do patrimônio cultural, são templos do conhecimento (PERROTTI; PIERUCCINI, 2014) destinados à pequena parcela da população, os iniciados na cultura letrada. Desenvolvem-se sob um paradigma de conservação cultural, ou seja, voltadas à organização e preservação da ordem do conhecimento. Num contexto em que o conhecimento é objeto de reverência, a biblioteca universitária tem como função a custódia, podendo ser caracterizada a partir da noção de "biblioteca templum" (PERROTTI, 2016). Nesse circuito, a relação dos discentes - essa ínfima parcela da população - com o conhecimento é de culto a uma verdade consagrada e estabelecida

\footnotetext{
${ }^{10}$ A partir de Pieruccini (2004, não paginado): "Entende-se o conceito de dispositivo de informação enquanto todo e qualquer mecanismo (técnico e simbólico) capaz de promover a relação, organizar a realidade e fornecer um instrumento para o pensamento (um texto, uma mensagem fotográfica, cinematográfica, um ambiente, uma prática); é possível caracterizá-lo como um quadro semiótico que produz significados, no interior do qual o sujeito opera. O dispositivo é, portanto, signo, mecanismo de intervenção sobre o real, que atua por meio de formas de organização estruturada, utilizando-se de recursos materiais, tecnológicos, simbólicos e relacionais, que atingem os comportamentos e condutas afetivas, cognitivas e comunicativas dos indivíduos. [...]Dispositivos de transmissão e comunicação, tais como as bibliotecas, que se utilizam de meios técnicos, linguagens e formas de interação intencionais, ao visarem à relação entre sujeitos e realidade, não são meros suportes de informação isentos. Ao contrário, sua configuração física, seus recursos, formas e práticas transformam seu discurso, sua estrutura e os modos de interação entre os sujeitos que lá atuam em ordem. Os dispositivos, enfim, não apenas expressam como também definem, por meio dos discursos implícitos em sua configuração, modos de relação entre os sujeitos e o universo simbólico (documentos, registros, informações, conhecimento) que guardam".
} 
por outrem. Portanto, não representam a si mesmos como produtores de conhecimento, na medida em que o próprio conhecimento não é encarado nessa perspectiva.

\subsection{CONHECIMENTO: EXPANSÃO E TRANSMISSÃO}

Nos primórdios da Europa moderna, o chamado conhecimento liberal era prestigiado, enquanto o dito conhecimento útil, como o do comércio e processos produtivos, possuía status inferior, assim como seus detentores - artesãos e mercadores -, na hierarquia social. Esta suposta superioridade do conhecimento liberal em relação ao útil é uma das consequências intelectuais de um modelo de sociedade em que as classes dominantes desvalorizavam o exercício do trabalho manual. Contudo, tal relação será desfeita numa Europa que vivencia expressivo aumento de conhecimentos em decorrência dos grandes descobrimentos, da invenção da imprensa e da revolução científica, que acabam delineando novas formas de relação dos sujeitos com o mundo e seus fenômenos. Ou seja, a própria noção de conhecimento adquire novos contornos num cenário em que as explorações marítimas, a expansão das trocas comerciais e o crescimento do aparato estatal demandavam novas ações dos sujeitos, tendo em vista lidar com esse mundo em construção, bem como ordená-lo. Assim, em fins do século XVIII o conhecimento útil se torna respeitável e acaba mesmo por ocorrer uma inversão na relação de importância entre este e o conhecimento liberal (BURKE, 2003).

A expansão do conhecimento foi acompanhada por seu aprofundamento, explicitado na fragmentação dos campos do conhecimento acadêmico, nos cursos e currículos da educação superior. O campo da Filosofia natural, por exemplo, foi cindido em temas virtualmente independentes que passaram a constituir novos campos, a História Natural, a Física, a Botânica e a Química. A História, por sua vez, tornou-se uma disciplina, situação facilitada por sua vinculação com o Direito e com a carreira política, enquanto a Geografia também ganhou espaço na academia (BURKE, 2003).

Em grande medida, essa expansão foi possibilitada pela imprensa, cuja importância não se limitou à difusão mais ampla do conhecimento. Ela facilitou a interação entre conhecimentos diversos ao padronizá-los, possibilitando que pessoas em diferentes lugares tivessem acesso aos mesmos conteúdos, fossem textos ou imagens. Do mesmo modo, possibilitou que as pessoas comparassem diferentes "verdades" sobre 
um mesmo fenômeno, o que, em alguma medida, contribuía para revelar o caráter de construção do conhecimento (BURKE, 2003).

O conhecimento se expande na Europa moderna em meio ao surgimento de Sociedades e Academias, instituições que agregavam intelectuais voltados ao debate e reflexão, conferindo identidade coletiva aos participantes. Esses lugares constituíam terreno de incentivo às discussões, pois eram abertos ao diálogo entre sujeitos, independentemente de serem academicamente respeitáveis. Os debates intelectuais eram possibilitados pelas formas de sociabilidade, ou seja, implicavam os contextos nos quais tinham lugar, desde a sala de seminários até as mesas de cafés (BURKE, 2003). Ao configurarem espaços para a livre circulação de ideias, as Sociedades e Academias evidenciam momento em que a sociabilidade se integra à noção de conhecimento, ou seja, as inter-relações entre sujeitos passam a constituir uma dimensão do conhecimento.

O processo de busca pela construção de um mundo "moderno" implicou a ampla valorização da linguagem escrita. Nesse âmbito, as bibliotecas desenvolvem-se, também graças ao surgimento da imprensa, aumentando de importância e tamanho nas universidades, começando até mesmo a rivalizar com a sala de conferências em algumas instituições (BURKE, 2003).

Face à expansão e especialização nos campos do conhecimento, e ao aumento do volume de obras impressas, as bibliotecas universitárias deparam-se então com a necessidade de elaboração de novas formas de organização dos acervos, viabilizando seu acesso e uso de-forma ágil. As diferentes categorizações propostas, assim como as bibliografias, mantinham relação direta com os campos do conhecimento. Ou seja, espelhavam um sistema de conhecimento ordenado, do mesmo modo que as disciplinas e os currículos faziam em seu escopo de atuação. A ordem dos livros era, assim, uma reprodução da ordem do currículo da universidade, e a biblioteca era responsável por sustentar esse sistema de classificação do conhecimento, ao torná-lo material, espacial e físico, como ainda o faz na atualidade (BURKE, 2003).

Nesse período as universidades permanecem voltadas à função de ensinar, o que exclui a ideia de pesquisa. Como ocorrera em período histórico anterior, o conhecimento é representado como bem passível de transmissão e o estudante como aquele que irá aprender - assimilar - conteúdos intelectuais. Para Burke (2003), em termos gerais, as universidades não configuravam lugares para o desenvolvimento de 
novas ideias, sofrendo de certa inércia institucional em meio à manutenção de suas tradições corporativas e isolamento de novas tendências no conhecimento.

Como se observa, nas universidades do período moderno o conhecimento foi sendo organizado e transmitido ao longo dos tempos, mas de modo geral sua produção e a formação de produtores de conhecimento não foi, de imediato, uma atribuição da educação superior. As universidades, com seus currículos e bibliotecas, constituíram instância de construção e manutenção de uma ordem social do conhecimento, transmitida aos seus participantes. Nesses termos, a história da biblioteca universitária é reflexo do desenvolvimento da noção de conhecimento implicada diretamente na educação superior, e seu papel e relevância evoluíram junto ao ensino superior, paulatinamente transformado em face de novas demandas, forjadas num contexto social mais amplo.

Em linhas gerais constatamos que, num momento em que o conhecimento é vinculado ao desenvolvimento das sociedades, as bibliotecas universitárias adquirem maior proeminência na função de promover o acesso ao patrimônio infodocumental, função que tem como corolário a transmissão de informações. Na medida em que o ensino superior se ampliava - num quadro ainda muito restrito -, o mesmo ocorria com as bibliotecas universitárias. Essa expansão reflete a ampliação do sentido de participação na ordem simbólica, bastante facilitada pelo surgimento da imprensa.

Em face disso, a biblioteca universitária da modernidade foi regida sob o paradigma da difusão cultural, podendo ser representada a partir do modelo de "biblioteca emporium" (PERROTTI, 2016), definido como dispositivo voltado à difusão de informações às parcelas da população que tinham acesso à educação superior. Nessa perspectiva, tanto na IES como na biblioteca universitária a representação de estudante não incluía a ideia de produtor de conhecimento, podendo-se concluir tratar-se de lógica inscrita em modelo comunicacional linear de emissãorecepção de bens simbólicos.

\subsubsection{Educação superior no Brasil: o conhecimento útil}

No Brasil, o início da educação superior tem como inspiração o modelo napoleônico, voltado à profissionalização num contexto em que é função da universidade contribuir para manter e ampliar o poder do Estado. Constitui-se, assim, 
com base na utilidade da formação das pessoas, não constando de suas atribuições o desenvolvimento de uma ciência independente (GOERGEN, 2000).

Foi nas décadas iniciais do século XX que o país começou a contar com universidades voltadas à formação de nível superior, criadas com a aglutinação de faculdades e institutos anteriormente isolados. Nesses termos, e com um modelo que propunha o ensino e a pesquisa, surge em 1920 a Universidade do Rio de Janeiro; em 1934, a Universidade de São Paulo; em 1946, a Universidade da Bahia. Junto às instituições de educação superior desenvolvem-se suas bibliotecas, com a função de atendimento à comunidade acadêmica (CUNHA, 2016; NUNES; CARVALHO, 2016). Tais ações ocorrem num quadro de transformações em que o Estado considera a educação superior importante ao desenvolvimento do país, especialmente a partir de 1931, quando foi instituído o regime universitário no Brasil (Decreto federal n ${ }^{\circ} 19.851$ de 11 de abril de 1931).

Em 1968, foi instituída a Lei da reforma universitária (Lei federal $n^{\circ} 5.540$, de 1968) que, ao invés de substituir o modelo de inspiração francesa por um projeto efetivamente brasileiro, instaurou no ensino superior um modelo de influência predominantemente estadunidense. A reestruturação do ensino superior teve como princípios condutores a eficácia e a eficiência num cenário de busca pelo desenvolvimento técnico-científico do país, conforme o entendimento dos grupos que detinham o poder político. Ocorreu também a ampliação do número de vagas para suprir a grande demanda estudantil, implantando-se o modelo do ciclo básico de estudos que possibilitava, a um custo reduzido, o atendimento a maior número de estudantes e que, na prática, consistia num período preparatório para o ciclo profissional (PEREIRA, 2007).

O sistema de educação superior brasileiro diferenciou-se entre público e privado a partir de política implementada nos anos 1970 que, paralelamente à referida ampliação do acesso, culminou na gradativa desobrigação do Estado como provedor da educação superior como direito a ser assegurado a todos, ao possibilitar a participação da iniciativa privada nesse circuito. Para Neves (1992), tal desobrigação caracterizou-se pela ausência de garantia de recursos financeiros contínuos, desarticulação entre a política para o ensino superior e as políticas de desenvolvimento científico e tecnológico, falta de reconhecimento da universidade como instituição de relevância cultural, social, política e econômica. 
Em consequência, houve aumento do número de IES privadas. Entretanto, nossa história recente é também marcada por políticas de ampliação do acesso ao ensino superior, ocorridas nas últimas duas décadas, objetivadas pela expansão da rede pública de estabelecimentos e do financiamento estudantil. Em face disso, atualmente, a educação superior pública e privada no Brasil pode ser quantitativamente expressa pelos números apresentados a seguir:

Tabela 1 - Número de instituições de educação superior, por categoria administrativa Brasil - 2017

\begin{tabular}{c|c|c|c|c}
\hline \multirow{2}{*}{ TOTAL } & \multicolumn{3}{|c}{ CATEGORIA ADMINISTRATIVA } \\
\cline { 2 - 4 } & \multicolumn{3}{|c|}{ PÚBLICA } & PRIVADA \\
\cline { 2 - 4 } & Federal & Estadual & Municipal & \\
\hline 2.448 & 109 & 124 & 63 & 2.152 \\
\hline
\end{tabular}

Fonte: INEP/MEC (2019a).

Tabela 2 - Número de ingressantes de graduação por categoria administrativa, segundo a organização acadêmica - Brasil -2017

\begin{tabular}{ccccccc}
\hline ORGANIZAÇÃO & TOTAL & \multicolumn{5}{c}{ CATEGORIA ADMINISTRATIVA } \\
ACADÊMICA & & \multicolumn{5}{c}{$\begin{array}{c}\text { PÚBLICA } \\
\text { PRIVADA }\end{array}$} \\
& & Total & Federal & Estadual & Municipal \\
\hline Total & 3.226 .249 & 589.586 & 380.536 & 181.665 & 27.385 & 2.636 .663 \\
Universidade & 1.721 .563 & 470.436 & 310.235 & 149.486 & 10.715 & 1.251 .127 \\
Centro Universitário & 668.955 & 4.993 & - & 258 & 4.735 & 663.962 \\
Faculdade & 766.523 & 44.949 & 1.093 & 31.921 & 11.935 & 721.574 \\
IF e Cefet & 69.208 & 69.208 & 69.208 & n.a. & n.a. & n.a. \\
\hline
\end{tabular}

Fonte: INEP/MEC (2019a). 
Tabela 3 - Número de ingressantes por vagas novas nos cursos de graduação presencial, por categoria administrativa, segundo a região geográfica - Brasil - 2017

\begin{tabular}{|c|c|c|c|}
\hline \multirow{3}{*}{$\begin{array}{l}\text { BRASIL/REGIÃO } \\
\text { GEOGRÁFICA }\end{array}$} & \multirow{3}{*}{$\begin{array}{l}\text { TOTAL DE } \\
\text { INGRESSANTES }\end{array}$} & \multicolumn{2}{|c|}{ CATEGORIA } \\
\hline & & \multicolumn{2}{|c|}{ ADMINISTRATIVA } \\
\hline & & PÚBLICA & PRIVADA \\
\hline Brasil & 2.152 .752 & 502.621 & 1.650 .131 \\
\hline Centro-Oeste & 210.724 & 56.005 & 154.719 \\
\hline Nordeste & 444.062 & 138.448 & 305.614 \\
\hline Norte & 144.085 & 44.419 & 99.666 \\
\hline Sudeste & 1.035 .883 & 177.498 & 858.385 \\
\hline Sul & 317.998 & 86.251 & 231.747 \\
\hline
\end{tabular}

Fonte: INEP/MEC (2019a).

Os números revelam aumento significativo da população que passou a ter acesso à educação superior, o que também correspondeu a uma maior diversificação de seus públicos. Conforme Vaz Filho (2019), nas últimas décadas aumentou significativamente a quantidade de estudantes indígenas e quilombolas em universidades brasileiras. Contudo, esse aumento não corresponde a novas formas das IES atuarem tendo em vista a integração efetiva desses públicos. Para o autor, as universidades parecem persistir inscritas em modelos que visam à reeducação de sujeitos pertencentes a grupos tidos como diferentes. Nesse sentido, embora a composição social das universidades venha sendo alterada, estas não se incluem, necessariamente, como lugares de interculturalidade ${ }^{11}$, perspectiva que ultrapassa a dimensão sociocultural.

Conforme indicado na Tabela 2, o ingresso em IES privadas é muito superior àquele realizado em instituições públicas, sendo que o fenômeno, conforme a Tabela 3 , ocorre independentemente da região geográfica. Observar a demanda suprida pela iniciativa privada é constatar que a educação superior se tornou negócio economicamente interessante, que concorre com o investimento do Estado, por vezes deficitário, por conta sobretudo da especificidade da universidade pública em

\footnotetext{
${ }^{11}$ De acordo com Oliveira (2011, p. 6), o prefixo "inter" "pressupõe reciprocidade." Nessa direção, "a interculturalidade remete à confrontação, ao entrelaçamento, ao que sucede quando pessoas e grupos entram em relação, o que implica negociação, conflito e trocas recíprocas (passar da aceitação da diferença, da tolerância, para a inter-relação, a efetiva trama)". A interculturalidade permite "participar da mobilização de recursos interculturais para construir alternativas".
} 
comparação às demais, haja vista também estar voltada à pesquisa e contemplar atividades de extensão.

Além da formação profissional, espera-se que a universidade pública produza conhecimentos em diálogo com perspectivas para o desenvolvimento social, cultural e econômico do país. Todavia, a universidade é expressão da sociedade que integra, assim como o conhecimento que produz, em alguma medida, é delineado pelo seu meio. Daí, a questão central do problema, na medida em que na atualidade o mercado se tornou o referencial de desempenho que valida socialmente a universidade (CHAUI, 2000; GOERGEN, 2000).

A universidade crítica e inovadora em suas funções, que compreendem o desenvolvimento e transmissão da ciência e cultura, a formação de profissionais que sejam, sobretudo, cidadãos de seu tempo e de sua história, afirmativos em suas relações com o mundo, é sacrificada face à busca pelo atendimento a demandas pautadas no mercado de trabalho. A conjuntura leva a maioria dos sujeitos à modalidade de educação superior voltada a exclusiva atuação num campo profissional, cuja eficácia e eficiência deixam à margem questões que impliquem o patrimônio cultural mais amplo. Desse modo, embora a educação seja meio de inserção e participação dos sujeitos na cultura de sua sociedade, a universidade - assim como as demais IES - parece considerar que a formação voltada a uma cultura científico-acadêmica específica e especializada, que diz respeito unicamente a um campo de atuação profissional, seja o caminho à constituição de quadros capazes de dar respostas às diferentes complexidades do país.

Não está em causa, obviamente, colocar em questão a relevância de uma preparação profissional, mas interrogar sobre a função redutora da educação superior voltada unicamente à formação de profissionais para o atendimento de demandas do mercado de trabalho, o que envolve diretamente o papel de instâncias que integram a universidade, especialmente suas bibliotecas.

Privilegiar a profissionalização, equiparando o sujeito com uma profissão é perder de vista que este, em sua relação com o mundo, vai muito além do exercício de um "ofício" (ORDINE, 2016). Levar a especialização ao extremo, desconsiderando sua articulação com o patrimônio cultural é incorrer no risco da formação de "bárbaros especializados", conforme argumentou Ortega y Gasset (1946); profissionais com total domínio sobre um campo, em termos operacionais, mas deslassados de seu próprio mundo, de sua própria história. 
Esse modelo de ensino que se consolida vai sendo reforçado por meio de representações utilitaristas do conhecimento, nas quais a produção simbólica é tomada a partir de critérios que delimitam "produção" ao estrito sentido econômico. Assim, conforme Almeida (2019), certos modos de conhecer são privilegiados, dada sua maior utilidade prática face às atividades profissionais vigentes em determinada sociedade.

Num país como o nosso, sobretudo, marcado por educação básica precária, a questão é agudizada. A partir dos resultados obtidos pelo Brasil no Programa Internacional de Avaliação de Estudantes (PISA) ${ }^{12}$ - exame que permite aferir conhecimentos e habilidades dos estudantes entre 15 anos e 3 meses e 16 anos e 2 meses de idade em leitura, matemática e ciências -, realizado em 2018, vemos que há uma fratura, um grande hiato que separa população escolar e conhecimento. Pela avaliação do PISA os estudantes brasileiros possuem baixa proficiência em leitura, ciências e matemática em comparação com os outros 78 países que integram a avaliação. O PISA revela que 50\% dos estudantes avaliados não possuem nível básico em leitura, necessário ao pleno exercício da cidadania. Em ciências são 55\%, enquanto em matemática esse número chega a $68,1 \%$. Em leitura, somente $0,2 \%$ dos estudantes brasileiros atingiram o nível máximo de proficiência. Esses números evidenciam os obstáculos que esses jovens terão para avançar nos estudos, ter oportunidades de trabalho satisfatórias e participar plenamente da sociedade enquanto sujeitos afirmativos. Para fins de comparação pontual, na Finlândia, no Canadá e na Coreia do Sul, o índice de estudantes que não atingiu o mínimo em proficiência em leitura é de 15\% (INEP/MEC, 2019b). Os resultados, por seu turno, não revelam o desempenho de pessoas tomadas individualmente, mas - e o que é ainda mais preocupante - do sistema de ensino de um país com profundas desigualdades socioeconômicas, cujas condições mínimas de sobrevivência e dignidade não são asseguradas a todos os seus cidadãos.

Evidenciar a deficiência do sistema de ensino básico é apontar para a problemática do ingresso na educação superior de muitos jovens que possuem uma formação prévia marcadamente deficitária. É inegável que diferenças, desigualdades e desconexões são também geradas pela desigual distribuição dos bens materiais e simbólicos, que tem reflexos nos entraves ao aprendizado, à apropriação simbólica.

\footnotetext{
12 "Realizado a cada três anos, o PISA tem o objetivo de mensurar até que ponto os jovens de 15 anos adquiriram conhecimentos e habilidades essenciais para a vida social e econômica. Em 2018, 79 países e 600 mil estudantes participaram do teste, que ocorre desde os anos 2000." (INEP/MEC, 2019b).
} 
Assim, embora o intuito da democratização do acesso ao ensino superior seja um importante passo, ele demanda novas ações de formação dos estudantes, sem as quais o desenvolvimento de relações críticas e afirmativas destes com o patrimônio infodocumental corre sério risco de não se concretizar.

Daí a importância da crítica ao contexto no qual a formação superior é colocada como uma espécie de especialização que, conforme Arendt (2016, não paginado), "não visa mais a introduzir o jovem no mundo como um todo, mas sim em um segmento limitado e particular dele”. Num país em que, em termos gerais, a educação superior é tida como oportunidade de mobilidade social para aqueles que desejam inserir-se em outros extratos sociais, há que se considerar que tais representações delineiam os contornos da relação do estudante com a educação superior e a IES (PEREIRA, 2007).

De acordo com Ribeiro (2014, p. 127), em grande medida a educação superior tem seus contornos estabelecidos a partir do mercado de trabalho, assim, "para uma profissão já existente, ou que se deseja criar, concebe-se uma graduação, que vai conferir o título que autorize exercê-la". Contudo, o mercado de trabalho nunca foi tão imprevisível quanto na atualidade e, se quisermos extrair daí um aprendizado para a educação superior, seria justamente o de não levar em conta o mercado de trabalho como um horizonte para a formação, dada sua própria impermanência e fluidez, cada vez mais acentuada. Caracterizar o mercado de trabalho como um ente definido a determinar as opções das pessoas, é desconsiderar que esse mercado se insere num mundo em que não existem parâmetros permanentes, não existem certezas. Por isso, conforme Ribeiro (2014), é mais pertinente que, ao longo de sua formação superior, o sujeito lide com aquilo que terá permanência e lhe dará bases sólidas a sua atuação no mundo, ao invés de se ocupar - e ser ocupado - com detalhes em constante mudança.

Nessa direção, a ideia de áreas de formação fechadas em si mesmas não condiz com a atualidade, pois a compartimentalização dos campos do conhecimento fragmenta e limita o próprio pensamento, assim como a atuação dos sujeitos no mundo. A religação dos saberes é condição à capacidade de aprender. À formação de sujeitos afirmativos, críticos em suas relações com o mundo e com os signos, é essencial considerar que a cultura, a ciência e o saber não são unidades totalizantes, congeladas, mas formas incompletas à espera do diálogo e de novas significações, o que indica a importância de um ensino em que se aprenda a religar para problematizar (LUZ; PERIM, 2007; RIBEIRO, 2014). Portanto, para a formação de profissionais e cidadãos críticos e criativos no mundo e em seu campo de atuação profissional, há que se 
interrogar sobre condições de possibilidade ao desenvolvimento de uma educação superior que incorpore o patrimônio cultural como elemento dinâmico e articulador das diferentes áreas de conhecimento.

As relações dos estudantes com o patrimônio cultural (simbólico) na educação superior incluem diferentes elementos, em especial os objetos simbólicos que se assentam sobre uma ordem socialmente construída que estabelece, pelo poder que exerce sobre os estudantes, o lugar que cada um ocupa na esfera do conhecimento. Além disso, estabelece os modos pelos quais os sujeitos se apropriam desses objetos e com que finalidades. Há aí, portanto, questões mutuamente implicadas que envolvem a biblioteca universitária, a sala de aula, as concepções que pautam os processos de construção de conhecimento e as aprendizagens. Esse conjunto articula a noção de conhecimento com a qual se defronta o estudante e que pode favorecer ou desconstruir princípios e representações utilitaristas de relação com o universo simbólico, forjadas em esferas mais amplas. Evidentemente, interpõe-se o desenvolvimento de chaves cognitivas às relações com a ordem simbólica as quais, de modo geral, não foram suficientemente desenvolvidas na educação anterior.

A finalidade do conhecimento sob o viés utilitarista, se é explicitada, não é, porém, interrogada em suas bases, apesar de intervir na relação dos sujeitos com a educação superior e seus dispositivos, assim como na construção de sentidos que afetam as representações que esses dispositivos constituem de seus públicos. Parece-nos que, a partir da noção de um conhecimento útil e eficaz, os não iniciados na ordem social do conhecimento acadêmico são desconsiderados do processo. A definição de estudante como produtor de sentidos diz respeito mais diretamente aos estudantes que tiveram melhores oportunidades de ensino bem como àqueles educados sob os moldes de uma dita cultura erudita, uma vez que têm o domínio das ferramentas cognitivas e culturais que permitem ler, interpretar, saber selecionar, situar as informações, fortalecidos em suas convicções e discursos. Nesses termos, a condição de produzir conhecimento seria destinada a uns poucos iniciados nesse sistema, enquanto parcela considerável dos estudantes estaria destinada, exclusivamente, a assimilação de conteúdos e a aprendizagem de fazeres para atuação num mundo-mercado? Pergunta retórica talvez, mas que objetiva questões de caráter epistêmico amplo, tendo em vista problematizar representações de biblioteca universitária existentes e reconstruir o conceito face aos novos contextos do século XXI. 


\subsubsection{A constituição da biblioteca universitária no Brasil}

A história da biblioteca universitária brasileira é reflexo da educação superior no país, e o surgimento e evolução da Biblioteconomia delinearam os rumos desse dispositivo, ao estabelecer procedimentos para a atuação profissional nesse universo bibliotecário. De forma geral, os Estados Unidos e países da Europa Ocidental são aqueles que forneceram referenciais tanto para o desenvolvimento de universidades como de suas bibliotecas, em escala mundial, o que compreende, portanto, o exercício de seus agentes. Em países da América Latina tal influência se fez presente e somou-se às especificidades de nosso contexto, com suas dinâmicas sociais, econômicas e culturais.

Na década de 1960, a biblioteca universitária brasileira é marcada pela influência de princípios que advogam pela centralização dos seus serviços, tendo em vista maior economia, com destaque para políticas de catalogação cooperativa, padronização de acervos, possibilidades de melhoria nas instalações físicas, dentre outros elementos. Eficácia e eficiência são palavras a abarcar tais iniciativas que resultam na busca pela criação de bibliotecas centrais, uma tônica desse período que se dá sob a influência de referenciais difundidos no $1^{\circ}$ Seminário Interamericano sobre Bibliotecas Universitárias, realizado na Universidade de Illinois, Estados Unidos, em 1961, pelo Council of Higher Education in American Republics. Essas ações em torno das bibliotecas universitárias vão ao encontro da reforma universitária que ocorreu em 1968 em nosso país, cujo rumo foi pautado no modelo estadunidense de ensino superior, e tendo como pressuposto que as bibliotecas deveriam ter atividades planejadas de acordo com as necessidades da própria universidade (CUNHA, 2016; NUNES; CARVALHO, 2016).

Em 1986, a criação do Programa Nacional de Bibliotecas Universitárias (PNBU), primeira iniciativa oficial de nível federal, trouxe diretrizes e ações para as bibliotecas universitárias, visando a garantia de condições para a definição de padrões de organização e desenvolvimento de sistemas e serviços bibliográficos nas universidades. As bibliotecas universitárias vivenciaram momento em que redes e sistemas compartilhados de informação foram constituídos por meio de projetos cooperativos, ações possíveis num quadro de mobilização de profissionais que atuavam no contexto e encabeçavam discussões em torno de questões inerentes a esse domínio. 
Entretanto, na década de 1990, as políticas do governo Collor alteraram as diretrizes de diferentes iniciativas governamentais, dentre as quais a desativação do PNBU e sua substituição pelo Serviço de Desenvolvimento de Bibliotecas das Instituições Federais de Ensino Superior. Marcada pela limitação de recursos financeiros, a mudança demonstrava alterações em relação à importância da questão dentro da agenda política do país naquele momento, ou seja, a intenção inicial contemplada pelo PNBU foi esvaziada, perdendo força dentro da esfera governamental (CUNHA, 2016).

Em fins da década de 1990 e início dos anos 2000, no contexto de expansão da internet e ferramentas online, diferentes iniciativas com vistas à organização e difusão da informação científica foram empreendidas, tais como a Scientific Electronic Library Online (SciELO), biblioteca eletrônica de acesso online gratuito a periódicos científicos; a disponibilização de plataforma aberta para editoração de revistas científicas e da Biblioteca Digital de Teses e Dissertações (BDTD), todas pelo Instituto Brasileiro de Informação em Ciência e Tecnologia (IBICT) (CUNHA, 2016). Esse cenário é marcado pelo crescimento do universo de informações científicas, produzidas em maior número em meio à ampliação do ensino superior no país e da pós-graduação, com sua importância para o desenvolvimento socioeconômico cada vez mais reconhecida. De um lado, essa expansão culmina no aumento significativo dos repositórios de informações científicas e, por outro, na maior necessidade de sua disponibilidade, por se tratar de matéria-prima para a atividade-fim desse circuito, cabendo às bibliotecas universitárias sua organização e disponibilização.

Como suas congêneres europeia e estadunidense, e sob suas influências, a biblioteca universitária desenvolve-se no Brasil tendo em vista dar suporte à educação superior. A princípio, sua função constitui-se a partir do foco na organização e disponibilização de um patrimônio infodocumental que reflete o sistema de conhecimento em causa nessa educação. Contudo, já nos fins dos anos 1980 e 1990, os referenciais da information literacy, termo cunhado pelo norte-americano Paul Zurkowsky (1974), adentram o país por meio de organismos internacionais como a American Library Association (ALA), a International Federation of Library Associations and Institutions (IFLA) e a Organização das Nações Unidas para a Educação, a Ciência e a Cultura (UNESCO). Tais referenciais influenciaram abordagens instrumentais da informação, focadas no uso competente das TIC em termos de habilidades para reconhecer quando a informação é necessária, localizá-la, avaliá-la e usá-la efetivamente (PERROTTI; PIERUCCINI; SÈRRES, 2018). Nessa abordagem 
considera-se a existência de um sujeito caracterizado como um receptor/usuário da informação, que precisa ser instrumentalizado para o uso eficaz da informação. Ser capaz de acessar, avaliar e fazer uso de informações caracteriza-se como formas de adaptação dos sujeitos a esse sistema do conhecimento, no qual a tônica da eficiência e eficácia se faz presente, numa perspectiva em que a biblioteca universitária é identificada com o paradigma da difusão cultural.

Atualmente, a biblioteca universitária é obrigatória à própria existência das IES, entretanto, tal obrigatoriedade é definida sob a perspectiva exclusiva do acesso, concepção que encontra abrigo na vigente legislação brasileira. Conforme o decreto federal $n^{\circ} 9.235$, de 15 de dezembro de 2017 - que dispõe sobre o exercício das funções de regulação, supervisão e avaliação das instituições de educação superior e dos cursos superiores de graduação e de pós-graduação no sistema federal de ensino -, a biblioteca universitária é caracterizada como infraestrutura física com a função de prover o acesso a recursos informacionais analógicos e digitais, confirmando seu papel como dispositivo circunscrito à oferta informacional. Sem desconsiderar a importância dessa dimensão, a perspectiva é insuficiente para subsidiar abordagens que tomem os estudantes como sujeitos produtores de conhecimento, o que implicaria compreender que produção do conhecimento e apropriação cultural da ordem simbólica são elementos de um mesmo binômio. Por esta razão, a biblioteca em contextos universitários, se compreendida como dispositivo inerentemente educativo, não se basta em sua função de oferta de produtos infodocumentais. Dada a problemática da educação superior entre nós, a biblioteca universitária é elemento chave da constituição de novos sentidos na relação dos estudantes com o conhecimento.

Podemos ilustrar a função da biblioteca universitária na educação superior a partir da metáfora de um supermercado e de uma cozinha. Nos moldes atuais a biblioteca parece configurar-se mais como um supermercado. Os estudantes vão até ela para adquirir determinados "produtos" - conteúdos intelectuais - disponibilizados a partir de serviços específicos. Enquanto supermercado, limitada à dimensão da oferta, seu objetivo é que os sujeitos consigam adquirir informações. Contudo, se o conhecimento, conforme ilustrou Lévi-Strauss (apud BURKE, 2012), pode ser considerado como aquilo que foi cozido, enquanto a informação seria o cru, propor a biblioteca como lugar de conhecimento seria tomá-la a partir de sentidos mais próximos aos da cozinha, lugar em que o sujeito aprende a fazer uso de diferentes utensílios geladeira, fogão, panelas, etc. - para o preparo de alimentos, misturados e 
transformados em algo novo, que tanto pode alimentá-lo como ser compartilhado com outros.

Um lugar de relações culturais/humanas com o patrimônio infodocumental, de experiências de produção de sentido e de (re)elaboração da imagem de si como sujeito do conhecimento. Se conforme afirmou Morin (2003), renovar a relação entre passado, presente e futuro deveria ser uma das finalidades da educação, parece-nos pertinente problematizar a biblioteca universitária, contribuindo com referenciais que abram caminhos nessa direção.

\subsection{CONHECIMENTO: REUNIR, CONTEXTUALIZAR, GLOBALIZAR INFORMAÇÕES E SABERES}

O conhecimento acadêmico, tomado como processo que compreende interrelações culturais entre sujeitos, a ordem simbólica e o mundo, demanda novas abordagens epistêmicas sobre a biblioteca universitária, ultrapassando tanto o paradigma da conservação como o da difusão. Enquanto o paradigma da conservação cultural delineou modelos de preservação da ordem simbólica, o da difusão cultural enfatizou a disseminação da memória cultural, constituída pelos circuitos socialmente hegemônicos, ao universo dos sujeitos encarados como receptores. A ampliação do acesso se deu em consonância à hierarquização de saberes, aspecto que não somente se refere ao reconhecimento da existência de diferentes naturezas de conhecimento, mas ao caráter valorativo e de distinção social atribuída aos portadores de determinados tipos de conhecimento. De fato, o questionamento sobre a ordem simbólica e os dispositivos que lhe dão sustentação é central na contemporaneidade.

Nessa perspectiva, trata-se de incluir no debate a redefinição da relação do estudante com a ordem simbólica enquanto processo de produção de sentidos, aspecto que extrapola noções de processamento de informações, conforme abordagens anteriormente referidas. Conforme Bruner (1990), o processamento de informações compreende significados previamente atribuídos às mensagens, considerando-se o sujeito como desprovido de sua condição de produtor de significados, alguém que recebe sentidos já acabados.

$\mathrm{O}$ ato de conhecer não corresponde à análise de problemas, enquanto manifestações isoladas que buscam soluções particulares e deixam à margem uma visão global do mundo e seus fenômenos. Promover a relação do estudante com o 
conhecimento sob tal viés seria atitude redutora face à complexidade do real. Segundo Martins (2007), é importante que o ato de conhecer não corresponda à busca por respostas simplificadoras ou à construção de visões redutoras do mundo e da humanidade, mesmo que isso tenda a ser buscado pelas pessoas, sobretudo diante das incertezas e em tempo de crises. A elaboração do conhecimento pertinente, implica "reunir, contextualizar, globalizar nossas informações e nossos saberes" (MORIN, 2010, p. 566). O ato de conhecer compreende a noção de autonomia intelectual, que se inscreve numa relação de dependência: assim como a autonomia do ser em relação à biosfera se dá em termos da dependência de matéria e de energia, o mesmo ocorre com a simbolosfera (MORIN, 2007). À maior autonomia do sujeito em termos intelectuais, corresponde uma dependência do patrimônio simbólico que é múltipla, na medida em que são os sujeitos que o preservam e ampliam. Para Queau (2010, p. 460-461), estamos vivendo a necessidade de "referenciais filosóficos e éticos capazes de ajudar-nos a pensar" sobre os rumos de nossa espécie e do planeta. Assim, desconsiderar a importância da relação crítica e afirmativa do estudante com a memória cultural é inscrevê-lo num caminho de descolamento de sua própria espécie e do mundo. Uma outra perspectiva impõe evidenciar o lugar do patrimônio infodocumental na formação superior, seja em termos da ordem de relações promovidas como de sua constituição. De outro modo, trata-se de manancial que, se diz respeito à formação especializada para a complexidade que afeta o mercado de trabalho, refere-se, sobretudo, à formação social e cultural mais ampla.

Há que se considerar que o patrimônio infodocumental implicado na educação superior comporta categoria específica de conhecimento e informação. Ao invés de um conhecimento de senso comum, no ensino superior os sujeitos travam relações com o conhecimento acadêmico, constituído a partir de parâmetros específicos, com ordenamentos e princípios que lhe conferem validação, os quais variam conforme os campos do conhecimento. Esse conhecimento gera informações científicas, que também se inscrevem em circuito particular de comunicação. Determinados ordenamentos configuram esse universo simbólico, bastante diverso do circuito de informações e conhecimentos com os quais muitos estudantes anteriormente lidavam, mesmo no âmbito da educação formal.

O conhecimento acadêmico é contrário às vagas generalizações e, por meio de métodos específicos, busca circunscrever dado objeto ou fenômeno, tendo em vista sua compreensão pelos sujeitos. Sua veracidade é estabelecida pelo emprego de método que 
comporta observação, formulação de hipóteses, verificação das proposições que as hipóteses levantam, assim como pela elaboração de parâmetros e critérios específicos, sendo expresso por linguagem própria manifesta em seus termos. Compreende a formulação de explicações a partir do escopo de uma teoria que, enquanto conjunto geral de enunciados, trata-se de construção, portanto, aberta a questionamentos, o que em outros termos significa dizer que as teorias estão sujeitas a revisões e reformulações a partir de novas investigações. Do mesmo modo, os conhecimentos não são fechados sobre si mesmos, não constituem crenças ou verdades universais, isto porque os fatos observáveis nunca provam a teoria que valida o conhecimento, apenas a confirmam em algum grau (ALBIERI, 2016; BACHELARD, 1990; LOGAN, 2012).

O conhecimento acadêmico é desenvolvido, assim, a partir de princípios que variam conforme os campos do conhecimento, portanto, sua disciplinarização é acompanhada por variações de método, os quais não correspondem ao conhecimento. Apesar das variações, tanto nas ciências exatas, biológicas ou humanas, a questão primeira do conhecimento acadêmico é o conhecer mais do que "como conhecer". Essa consideração é importante na medida em que reduzir a compreensão do conhecimento acadêmico ao nível do método científico pode levar a supervalorização de um modo de produzir conhecimento em detrimento de outros, ou seja, hierarquizações, ocasionando equívocos acerca do processo de conhecer (ALMEIDA, 2019). A afirmação pode ser ilustrada a partir de exemplo fornecido por Lansing e Kremer $\left(1993^{13}\right.$ apud SANTOS, 2009) sobre sistemas milenares de irrigação de plantações de arroz em Bali, na Indonésia, os quais eram baseados em conhecimentos agrícolas, hidrológicos e religiosos ancestrais, e administrados por sacerdotes de um templo hindu-budista. Segundo os autores, tais sistemas foram substituídos por serem considerados produto da superstição, porém, a troca resultou em redução expressiva das colheitas, resultado que se repetiu em colheitas seguintes, levando ao abandono desse sistema e retorno ao anterior. Nesse caso, um conhecimento validado como científico e tomado como superior sobrepôs-se a um conhecimento milenar, na medida em que este não compartilhava dos mesmos métodos de validação de suas premissas. O exemplo evidencia, de acordo com Santos (2009, p. 43), que "a compreensão do mundo excede largamente a compreensão ocidental do mundo".

\footnotetext{
${ }^{13}$ LANSING, J. Stephen; KREMER, James N. Emergent properties of balinese water temples: coadaptation on a rugged fitness landscape. American Anthropologist, v. 95, n. 1, p. 97-114, 1993.
} 
Nessa perspectiva, o conhecimento acadêmico não é autônomo nem universal, é construção contextualizada tanto em termos de diferenças culturais como políticas. Assim, não existem epistemologias ${ }^{14}$ neutras, como também não há conhecimento sem sujeitos e práticas sociais. E, se tanto os sujeitos como as práticas existem em relações sociais, estas distintas relações sociais podem originar epistemologias diversas. Embora práticas de conhecimento possam ocorrer em meio ao reconhecimento da diversidade cultural do mundo, isso não corresponde diretamente ao reconhecimento de uma diversidade epistemológica, já que relações de poder definem a significação do mundo, de seus objetos e fenômenos. Diferenças culturais, sociais e políticas compõem as tramas do conhecimento, delimitando aquilo que será validado, imprimindo um caráter unifocal ao conhecimento. Em face disso, tomar a diversidade epistemológica do mundo como premissa, ou seja, reconhecendo a presença de uma pluralidade de formas de conhecimento, implica a renúncia a qualquer "epistemologia geral", assumindo-se que a diversidade cultural do mundo pode contribuir no desenvolvimento das sociedades, ao possibilitar que sejam concebidas de forma multifocal (SANTOS, 2009).

A diversidade cultural também implica a noção de mobilização, o desejo de conhecer dos sujeitos, diretamente atrelado a suas experiências. Portanto, é essencial que instâncias privilegiadas ligadas ao conceito de produção do conhecimento incorporem a diversidade cultural como caminho à ampliação das próprias fronteiras do conhecimento acadêmico.

De outro lado, o conhecimento acadêmico é gerador de uma categoria específica de informação, a informação científica, que tem como características:

- ser obtida durante um processo de conhecimento acadêmico e destinada, de alguma forma, a intervir no real;

- ser processada e generalizada pelo pensamento lógico abstrato, o que a diferencia de dados obtidos aleatoriamente pelos seres humanos em processos de percepção sensorial;

- ser empregada em práticas sociais e históricas, evitando que informações do senso comum, ficção ou de conhecimentos pseudocientíficos sejam consideradas informação científica (MIKHAILOV, 1967; MIKHAILOV; CHERNYI;

\footnotetext{
${ }^{14}$ Conforme Santos (2009, p. 9): "Epistemologia é toda a noção ou ideia, refletida ou não, sobre as condições do que conta como conhecimento válido. É por via do conhecimento válido que uma dada experiência social se torna intencional e inteligível".
} 
GILYAREVSKYI, 1969, $1973^{15}$ apud SANTOS JUNIOR; PINHEIRO, 2010, p. $33)$.

Essa natureza da informação não se limita a conteúdo específico, mas também compreende o processo de sua elaboração e comunicação. No cenário atual, com os fluxos informacionais marcados pelas TIC, tanto a geração como a comunicação das informações científicas vêm sendo transformadas. Os dados de pesquisa, por exemplo, estão cada vez mais presentes no universo da produção e partilha do conhecimento, passando a ser abarcados pela noção de informação científica (SCHOPFEL, 2017). Portanto, a relação efetiva do estudante com a informação científica implicará o domínio de seus aparatos de comunicação e disponibilização que configuram molduras a partir das quais esse universo é visto e que, em decorrência, delimitam nossas relações com ele.

As informações científicas também reproduzem a disciplinarização dos campos do conhecimento que as geraram. Nesse sentido, informações legais, químicas, matemáticas, financeiras, sociais, etc., irão corresponder a definições, critérios, padrões, metodologias e especificidades de seus campos epistêmicos de origem, incorporando características que irão variar conforme cada um. Essa multiplicidade também se faz presente em alguns conceitos-chave para a compreensão da informação científica, assim, o conceito de documento, por exemplo, pode ter significado diverso para um historiador, um advogado ou um biólogo (MALINGRE; SERRES, 2011).

Tanto o acesso como a apropriação dessas informações são definidoras de possibilidades à ampliação da esfera de presença do ser no mundo. Mais que ser habitante do planeta, ser sujeito no mundo significa presença crítica, criativa e geradora implicando relações afirmativas com o patrimônio cultural que constitui abrangência ao nosso pensamento. Nesses termos, a uma reforma do pensamento é demandada a reforma de instituições como IES e bibliotecas, pois, conforme Teixeira (1954), o pensamento não é atividade unicamente individual e subjetiva, mas, resultado de uma

${ }^{15}$ MIKHAILOV, A. I. Informatics: a scientific discipline. Documentação e Informação Científica, Lisboa, v. 10, n. 53, p. 239-242,1967.

CHERNYI, A. I.; GILYAREVSKY, R.S. Informatics: its scope and methods. In: MIKHAILOV, A. I. On theoretical problems of informatics. Mouciu: FID/Comitê de Estudo sobre Pesquisa de Base Teórica da informação. Moscou: Viniti, 1969.

MIKHAILOV, A. I. Fundamentos de la informatica. Habana: IDICT/Academia de Ciências de Cuba. Havana IDICT, 1973. 2 v. 
ação complexa envolvendo sujeitos e dispositivos de relação com a ordem simbólica. Dispositivos que, além de possibilitarem relações com essa ordem, delimitam seus contornos os quais, por sua vez, demandam revisões teóricas para que a diversidade epistemológica do mundo seja representada no patrimônio que sistematizam e disponibilizam.

A uma representação de conhecimento que compreenda reunião, contextualização e globalização de informações e saberes estão em causa condições de possibilidade de diálogo com o patrimônio cultural, o que inclui, sobretudo, a experiência do estudante compreendido como sujeito de sentidos. Vale insistir, alguém que em sua relação com a ordem simbólica reúne informações e saberes, os contextualiza face à ordem humana e em diálogo com sua experiência, como condição de ampliação de sua esfera de presença no mundo. Essa representação de conhecimento implica a diversidade cultural como critério ao desenvolvimento de uma diversidade epistemológica, essencial ao princípio de sustentabilidade terrena, em todas as dimensões.

A abrangência da proposição envolve outras representações de biblioteca universitária que compreendam discussões teóricas sobre a ordem simbólica e sobre as relações que promove entre sujeitos e patrimônio infodocumental. Com isso, afirmamos a importância do desenvolvimento de modelo epistêmico que oriente a biblioteca universitária contemporânea do século XXI.

Em face disso, o conceito de mediação cultural emerge como categoria operatória às nossas incursões teóricas, pois, conforme Nunes e Cavalcante (2017) possibilita compor bases teóricas para abordar a informação como construção social, representada como produção simbólica que compreende sociedades e culturas, não se restringindo a condições materiais e técnicas. Sob esse ângulo, a categoria da memória cultural constitui objeto destacado da biblioteca universitária, com reconhecimento de sua especificidade científico-acadêmica.

Considerando o diálogo com a memória cultural como atos de significação, a mediação cultural é conceito que remete à importância de se considerar dissonâncias entre o quadro fragmentário de relações entre estudante e patrimônio infodocumental. A constatação abre espaço para descontruir valores que enfatizaram modelos comunicacionais lineares nos quais o estudante é caracterizado tão somente enquanto receptor e processador de informações. 


\subsubsection{Mediação cultural: uma abordagem para além da prática}

Abordamos a comunicação como um processo social implicando diferentes atores ligados entre si e a um ou mais sistemas mediadores, sejam instituições sociais, sistemas culturais de signos ou, ainda, representações coletivas (BOLLE DE BAL, $2003^{16}$ apud ARASZKIEWIEZ; COULBAUT-LAZZARINI; COUSTON, 2019). Assim, a ideia da comunicação como processo técnico de transferência de informação entre emissor e receptor é extrapolada, passando-se a considerar as vinculações entre sujeitos e sistemas simbólicos, bem como as relações que estabelecem a partir de sistemas de mediação cultural e seus dispositivos.

Ao tratarmos a biblioteca universitária em tal perspectiva comunicacional, de um lado ultrapassa-se a dimensão técnica da conservação e da transferência de informações entre um emissor (a biblioteca) e seus públicos (a comunidade acadêmica); de outro supera-se a dimensão interacionista na qual a comunicação é interação entre sujeitos sociais, incluindo-se então a dimensão mediática. (DAVALLON, 2007).

Assim, a comunicação cultural $^{17}$ é adotada como abordagem teórica do desenvolvimento da biblioteca universitária sob o modelo epistêmico da mediação cultural, tomada como ato de produção de sentidos; com isso, os papéis dos sujeitos no processo comunicacional são redefinidos. Tal abordagem permite ainda romper com quadros epistemológicos que validaram concepções de informação e comunicação que reduzem a mediação a uma dimensão instrumental, ora consistindo em fazer aceder um público a conteúdos intelectuais ou saberes, ora em construir interfaces entre universos estranhos entre si (DAVALLON, 2007).

Nessa perspectiva, a biblioteca universitária é vista como um dispositivo inscrito num processo comunicacional triangular, baseado na mobilidade dos envolvidos produtor, receptor, distribuidor -, não havendo posições fixas a ser ocupadas, quem recebe também produz e distribui (BATISTA, 2014). A linearidade do modelo da transmissão e recepção, no qual as relações entre sujeitos e informações são representadas de forma fixa, mostra-se ultrapassada para o entendimento de processos

\footnotetext{
${ }^{16}$ BOLLE DE BAL, Michel. Reliance, déliance, lianc: émergence de trois notions sociologiques. Sociétés, v. 2, n. 80, p. 99-131, 2003.

17 A comunicação cultural foi apresentada como paradigma político-cultural às bibliotecas pelos professores Edmir Perrotti e Ivete Pierrucini, em agosto de 2020, na disciplina Mediação Cultural: teoria e prática ministrada no Programa de Pós-Graduação em Ciência da Informação da ECA-USP.
} 
simbólicos como atos de significação/criação. Na abordagem triangular não está em causa caracterizar os sujeitos como potenciais produtores e distribuidores, que assim se constituem à medida que recebem informações e aprendem dadas formas de relação com o universo simbólico. Isto equivaleria a adotar tal abordagem como finalidade do processo comunicacional e não como ponto de partida, o que, por si só, inviabilizaria a própria reelaboração da abordagem dos dispositivos de informação e cultura.

$\mathrm{Na}$ abordagem da comunicação cultural a própria origem da ação, ou seja, da comunicação, é considerada a partir da mediação, o que possibilita a apreensão conjunta das dimensões técnica e social da comunicação, tornando possíveis as trocas sociais já que os universos de produção e recepção são, a princípio, disjuntos por natureza. Com isso, é destacada a articulação entre distintos elementos (sujeitos, interações, universo simbólico, etc.) num dispositivo específico (a biblioteca, por exemplo) o que, por sua vez, revela a dimensão criadora da mediação que, mais que viabilizar sentidos, os produz. Ou seja, a mediação é ato de significação (DAVALLON, 2007; PERROTTI; PIERUCCINI, 2014).

Por outro lado, não há um consenso sobre a noção de mediação e seus derivados como mediação cultural e mediação da informação (DUFRÊNE; GELLEREAU, 2004). Conforme Santos Neto (2019), os conceitos abrangem tanto uma extensão como uma compreensão. Embora alguns autores possam chegar a uma compreensão bastante próxima do conceito, poderão divergir quanto aos contextos em que se enquadra. Logo, a extensão do conceito pode ser diversa e gerar derivações como mediação da informação, mediação cultural, mediação pedagógica, mediação da leitura, etc.

Almeida Júnior (2009) indica que no âmbito da Ciência da Informação o termo mediação é empregado sem uma conceituação específica que o defina. Para o autor, a noção integra o discurso da área sem, entretanto, fornecer parâmetros ao embasamento de práticas em instituições de informação e cultura. Apesar disso, Nunes e Cavalcante (2017) evidenciam que o senso comum, que define mediação como "ponte" - aquilo que possibilita interação entre dois pontos fixos -, não reflete as recentes pesquisas sobre a temática na área, que têm concebido a mediação de modo processual, vinculando-a à apropriação. Diante disso, apesar da indicação de avanços conceituais em torno da noção de mediação, a Ciência da Informação demanda reflexões teóricas que forneçam parâmetros às suas práticas as quais, de modo geral, acabam sendo caracterizadas como transmissão qualificada de informação. A seguir, discutiremos o conceito com vistas a contribuir nessa direção. 
Afastando-nos de possíveis confusões com a mediação inscrita em outros domínios - como o político, jurídico, social, religioso, etc. - somamos o adjetivo cultural ao termo mediação para qualificá-lo e restringi-lo ao domínio das práticas comunicacionais em dispositivos de informação e cultura, como as bibliotecas. Conforme Perrotti e Pieruccini (2014), a noção de mediação cultural (CAUNE, 2000; DARRAS, 2003; PERROTTI; PIERUCCINI, 2014) foi difundida especialmente no período posterior à Segunda Guerra Mundial, contexto em que a informação passa a adquirir centralidade na vida cotidiana.

A mediação cultural é conceito operatório para descrever e analisar variados processos em contextos específicos. É possível abordar a mediação cultural em teatros, museus, bibliotecas, etc. Nas bibliotecas a mediação cultural pode envolver processos que vão desde o desenvolvimento dos acervos até sua disponibilização ao público. (DAVALLON, 2007).

Recorrendo à etimologia do termo, a partir de Lalande (1993), constatamos que mediação procede do adjetivo inglês mediate - apesar de também admitir vinculação com o francês mediat e médiation -, que dá origens ao substantivo médiation e derivados como intermediation (SIGNATES, 1998). Jeanneret (2005) indica que o termo tem origem nos campos religioso (Jesus intercedeu na relação Deus e humanidade, os santos intervêm junto a Deus a partir das preces dos mortais) e jurídico (a mediação é tentativa de conciliação em um processo), aludindo à necessidade de intermediações no domínio das inter-relações sociais. Nessa perspectiva, de acordo com Araszkiewiez, Coulbaut-Lazzarini e Couston (2019), mediação remete a um meiotermo, lugar imparcial em que um debate pode se dar e, também, a uma pessoa que possibilita a resolução de uma dificuldade, o que sem ela seria inviável.

De outro lado, a mediação não é neutra, ela orienta e delineia a comunicação, a distribuição da palavra, a síntese das informações. Para Martín-Barbero (1987), a mediação realiza-se tanto pelo emprego de técnicas como de saberes específicos, constituindo-se como esfera de significação. Assim, o termo compreende diferentes elementos que envolvem o ser humano em sua trajetória como ser vivente, desde sua natureza, sua história e o meio em que se encontra. O próprio significado do ser humano como indivíduo se dá “após um desenvolvimento milenário de mediações e o seu pressuposto real é o de ser sempre membro de uma comunidade" (RAMBALDI, 1989, p. 145). 
A mediação compreende um contexto de relações, forjadas na simbolosfera, em que o sujeito adquire e (re)elabora significados sociais e culturais, seus e de sua sociedade. Para Vygotsky (1989), a mediação está implicada no desenvolvimento intelectual das pessoas, já que este ocorre em meio a um processo interacionista que compreende sujeito, saber-objeto de aprendizagem, demais sujeitos e um contexto específico. Assim, conforme Santos e Gomes (2015), é processo interacionista e também dialógico.

Caune (2000), evidencia a mediação como um conceito, instrumento para contribuir com as discussões teóricas sobre questões simbólicas concernentes à comunicação da espécie humana. Assim, aborda a mediação como fenômeno que auxilia a compreender a difusão - no espaço e no tempo -, de formas da linguagem e de formas simbólicas que produzem significação partilhada em dada sociedade. Ou seja, embora compreenda um processo individual, a mediação inscreve-se na esfera da partilha simbólica. Portanto, conforme Santos e Gomes (2015), é ação compartilhada e colaborativa, produtora de sentidos, que entra em relação com os sentidos dos objetos, dos sujeitos e dos respectivos contextos. Logo, não se trata da produção de consensos, é ato de criação, sendo possível caracterizá-la como "conjunto de práticas sociais desenvolvidas em distintos domínios institucionais e que objetivam construir um espaço determinado e legítimo para as relações que neles se manifestam" (CAUNE, 2000, p. 2, tradução nossa). Em face disso, para o desenvolvimento de representações de biblioteca universitária, tendo a mediação cultural como modelo epistêmico, é preciso empreender discussões teóricas em função das relações que ela promove e autoriza - entre sujeitos e o patrimônio infodocumental.

Por sua vez, enquanto conjunto de práticas sociais em domínios distintos, a mediação revela-se situacional, ou seja, transforma-se com as dinâmicas sociais e culturais. Com isso, tende a se transformar face às novas tecnologias de informação e comunicação, que ampliam as possibilidades de acesso, circulação e produção de informações. Contudo, embora o sistema de mediações simbólicas guarde relações com o circuito de mediações técnicas, é essencial compreender que a mediação cultural compreende a esfera das significações, a interação entre sujeitos mediatizada pelo simbólico (ARASZKIEWIEZ; COULBAUT-LAZZARINI; COUSTON, 2019). Essa consideração é fundamental para que mediação cultural não seja confundida com inovação em termos tecnológicos, melhoria de formas de transmissão da informação. Portanto, na abordagem da comunicação cultural, o funcionamento simbólico da 
sociedade é o que está implicado no conceito de mediação, e não as técnicas de transmissão.

A partir da literatura abordada, estabelecemos o seguinte quadro de elementos inerentes à mediação cultural:

- Uma ordem simbólica determinada. Constitui a exterioridade e intervém no processo de comunicação. São as diferentes culturas das sociedades, ordens compostas por princípios e valores a partir dos quais as manifestações adquirem sentido e produzem sentidos que vinculam a coletividade. Os sujeitos não têm controle sobre ela.

- Um caráter indeterminado. Não dispõe de fórmulas para chegar a um fim estabelecido e homogêneo. $\mathrm{O}$ indeterminado manifesta-se na medida em que a mediação intervém na produção de signos e é marcada pelo político, intersubjetividade e linguagem. Assim, o caráter contingente da ordem simbólica determinada e exterior aos sujeitos é revelado. Com isso, temos possibilidades de (re)elaboração dessa ordem a partir de processo interacionista e dialógico de sujeitos de palavra entre si e com o patrimônio simbólico. Essa dimensão revela, de outro lado, a importância de se considerar as necessidades - explícitas e latentes - de informação e cultura, assim como os desejos, como forças propulsoras que mobilizam os sujeitos em dinâmicas de relações com a ordem simbólica.

- É situacional. As ações desenvolvem-se na articulação de dispositivos de informação e cultura de natureza técnica, semiológica e pragmática, inscritos na ordem simbólica. Implica atores, modos de fazer e lugares, assim como um sentido social e cultural, revelando que a mediação se delineia em relação a contextos específicos, incluindo, portanto, uma dimensão histórica e sociocultural.

- É formativa. Essencial ao processo de desenvolvimento intelectual do sujeito. Compreende um sujeito de palavra, alguém que se relaciona com o mundo por meio da linguagem, ampliando não apenas repertórios simbólicos, mas as próprias fronteiras do pensamento. Essa dimensão revela o caráter mediador dos signos e a mediação como portadora de sentidos. 
Diante do exposto, a mediação cultural emerge como conceito operatório para discussões teóricas em torno da biblioteca universitária, possibilitando que o processo comunicacional do qual participa seja compreendido como ato de significação. Tal perspectiva rompe com práticas bibliotecárias centradas no modelo comunicacional linear, que tomam o estudante como destinatário final da comunicação e como alguém que, se bem treinado, irá conseguir produzir significados. Em face disso, parece-nos fundamental observar o caráter determinado e indeterminado da mediação cultural, pois podem configurar caminho para o desenvolvimento de representações de biblioteca que, além da exterioridade - o patrimônio cultural -, compreendam as inter-relações entre os sujeitos, a ordem simbólica e seus dispositivos. Nesses termos, é abordagem teórica que rompe com lógicas que tomam a informação como valor acima da produção de sentido e, também, considera a especificidade científica da memória cultural organizada e disponibilizada pela biblioteca universitária. Assume-se então que nesse circuito são demandados saberes específicos à apropriação cultural. Com isso, o patrimônio infodocumental sistematizado pelas bibliotecas universitárias tem sua especificidade científico-acadêmica considerada e passa a ser caracterizado como manifestação aberta aos atos de significação, o que por sua vez alça estes dispositivos à condição de instância de negociação simbólica por sujeitos tomados como produtores de sentido.

Desta forma, eleger a mediação cultural como modelo epistêmico (conceito teórico) de abordagem da biblioteca universitária, corresponde à busca por referenciais que se distanciam da ideia de mediação cultural como prática, visando processos eficientes de transmissão da informação. Como modelo epistêmico, mediação cultural refere-se à relação entre sistemas culturais distintos e diferentes, porém igualmente relevantes, tendo em vista o diálogo intercultural. O que está em questão, portanto, são culturas que espontaneamente não se articulam, por fazerem parte de universos nascidos de lógicas específicas e por vezes dissociadas, como no caso a cultura científicoacadêmica e a cultura dos estudantes. Representar a biblioteca universitária como dispositivo de mediação cultural significa considerar, assim, a produção de sentido, os atos de palavra, as práticas sensíveis e inteligíveis como questão central a ser atingida por processos interculturais que permitam ao estudante se elaborar em relação ao outro (ao mundo, a sua espécie, à simbolosfera); forma privilegiada de vivência desse sujeito de palavra.

Em face disso, podemos afirmar que a mediação não é fruto ou caminho para a comunicação. Ela já constitui o processo comunicativo, uma vez que este envolve o 
acionamento de mediações simbólicas num lugar "comum" - a simbolosfera - em que os sujeitos se elaboram em relação aos símbolos de sua espécie. De acordo com Caune (2000; 2006), a mediação cultural é a experiência da relação entre um sujeito de palavra (sujet de parole), uma manifestação - um fato perceptível -, e um mundo de referências, ou seja, uma cultura a partir da qual as manifestações adquirem sentido. Portanto, ao mesmo tempo em que existe uma ordem simbólica - o determinado - há o indeterminado, aquilo que advém das maneiras de fazer e que revela os limites da mediação (CRESPI,1983, p. $22^{18}$ apud DAVALLON, 2007; CERTEAU, 2003). Sendo assim, a mediação não remete à ideia de formar o outro a partir de um molde preestabelecido, pois compreende interações entre culturas e seres de significações.

${ }^{18}$ CRESPI, Franco. Médiation symbolique et société. Paris: Librairie des Méridiens, 1983. (Coleção Bibliothèque de l'imaginaire). 


\section{A EXPERIÊNCIA DE SI NA EDUCAÇÃO SUPERIOR}

"Quem é você??" perguntou a Lagarta. [...] Alice respondeu, meio encabulada: "Eu... eu mal sei, Sir, neste exato momento...pelo menos sei quem eu era quando me levantei esta manhã, mas acho que já passei por várias mudanças desde então." "Que quer dizer com isso?" esbravejou a Lagarta. "Explique-se!"

"Receio não poder me explicar" respondeu Alice, "porque não sou eu mesma, entende?" (CARROLL, 2010, não paginado)

Este capítulo discute a experiência de si (LARROSA, 1994) do estudante universitário, considerando que o ingresso na educação superior configura sua inserção numa nova cultura, a cultura científico-acadêmica que, dentre outros elementos, compreende um patrimônio cultural específico, constituído por informações científicas e pelo conhecimento acadêmico. Ingressar na educação superior é adentrar num circuito que coloca o sujeito face a novas demandas de relações com o meio e, consequentemente, consigo mesmo, configurando momento marcado por transformações de diferentes ordens. A entrada num novo território simbólico configura um deslocamento identitário e, para muitos, o ingresso na educação superior é momento de encontro com uma ordem simbólica que lhes é estranha.

Se "Je suis l'espace où je suis"19 - conforme poeticamente afirmou Arnaud (apud TEIXEIRA COELHO, 2001, p. 78) indicando a relação vital entre o lugar e o ser -, a apropriação do meio pelos sujeitos revela-se essencial para sua transformação e, também, à transformação do meio. Contudo, constatamos um quadro problemático no âmbito das relações dos estudantes com a cultura científico-acadêmica, envolvendo diretamente processos e procedimentos que permitam relações significativas com a informação e o conhecimento. Há aqueles estudantes que elaboram a imagem de si como alguém não pertencente ao meio, alguém que não é apto a negociações com esse universo. Para estes, o conhecimento é compreendido como algo a ser (ansiosamente) assimilado, não enxergando-se como sujeitos do processo. Questão problemática, porque impacta relações com a ordem simbólica, e ressalta a importância de contextos

\footnotetext{
${ }^{19}$ A citação foi mantida em francês, conforme Teixeira Coelho (2001, p. 78), pois na língua portuguesa os verbos ser e estar têm sentidos distintos, diferentemente do francês, que funde esses dois sentidos em être. A tradução seria "Eu sou (ou estou) o espaço onde eu estou (ou sou)".
} 
específicos que compreendam o estudante como sujeito de palavras que interage com essa ordem em dinâmicas de produção de sentido. Para além de fenômeno pontual que afeta sujeitos em condições específicas, o problema remete à ordem do conhecimento, que estabelece direitos de fala e de escuta, consagrando a alguns o lugar de produtores e aos demais o da recepção e consumo sígnico, implicando assim desdobramentos que atingem as esferas da criação e reprodução de saberes. Tal questão nos levou a interrogações acerca da importância de ultrapassar modelos que definem tais posições, considerando-se, sobretudo, que o paradigma difusionista - que preside a lógica da biblioteca universitária - não consegue integrar a significação como categoria do processo comunicacional que caracteriza o dispositivo cultural.

Ainda mais se considerarmos as mudanças ocorridas nas últimas décadas, com a ampliação do acesso ao ensino superior em meio a um quadro de precariedades do ensino básico. Nesse contexto, essa discussão se mostra essencial à própria manutenção, ampliação e renovação dos campos do conhecimento, bem como das profissões, já que os estudantes são seus membros e configuram seu futuro. Tanto na educação superior como no processo do conhecimento não estão em causa apenas relações sociais, mas também relações culturais, relações semióticas entre sujeitos e a simbolosfera, constituída por sua vez pelos diferentes universos simbólicos e culturais. Assim, acreditamos que a inclusão da diferença como categoria geradora de conhecimento e cultura é uma perspectiva essencial às bibliotecas universitárias.

\subsection{A CULTURA CIENTÍFICO-ACADÊMICA}

Como já afirmamos, o ingresso no ensino superior configura um deslocamento do sujeito para um novo território marcado por características específicas. Mais que um novo espaço, está em causa a relação com uma nova cultura: a cultura científicoacadêmica, que constitui um conjunto de esquemas de mediação da experiência do estudante e, conforme Larrosa (2017), delimita e atribui perfis às pessoas a partir das inter-relações aí estabelecidas.

A cultura científico-acadêmica é fundamentalmente formada por valores e atitudes $^{20}$ partilhados pelos sujeitos que a compõem - professores, estudantes,

\footnotetext{
${ }^{20}$ A partir de Sarabia (2000, p. 122, 124-125), atitudes envolvem um componente afetivo e a tendência à ação. Seriam, então, "tendências ou disposições adquiridas e relativamente duradouras a avaliar de um modo determinado um objeto, pessoa, acontecimento ou situação e a atuar de acordo com essa avaliação",
} 
pesquisadores - e que nela ocupam posições diversas. Implica um circuito - o ensino superior - desenvolvido em dinâmicas de reprodução, construção coletiva, aprendizagem e validação, no qual as atitudes de seus membros são forjadas, em certa medida, em função dos valores que constituem essa cultura (JACOB, 2007).

Embora saibamos que a cultura científico-acadêmica é formada por distintos elementos - seus ritos, códigos e valores, suas práticas marcadas por uma cultura patrimonial, nacional, sua história educativa em nível nacional ou regional, assim como seus critérios de seleção, ritos de passagem e seus comportamentos codificados (BOURDIEU, 1982; POUZARGUE, $1998^{21}$ apud GOHARD-RADENKOVIC, 2002) -, o que torna possível abordá-la a partir da natureza desses fenômenos, neste estudo adotamos a abordagem de Caune (2000), que propõe compreender a cultura a partir das interações que nela se realizam. Assim, nosso enfoque recai sobre os atos de palavra do sujeito, sua experiência e construção em meio às inter-relações que estabelece na cultura; ao invés de privilegiarmos enfocar a posse ou acesso a um determinado bem ou domínio. Nessa perspectiva, as maneiras de fazer das pessoas (CERTEAU, 2003), suas interações com os outros e com o meio são catalizadoras de transformações da própria cultura. Parte-se do princípio de que os estudantes são seres de significados com potencial para (re)significarem a própria cultura.

A abordagem parece-nos essencial ao desenvolvimento de dispositivos comprometidos com a democracia cultural na educação superior, rompendo com perspectivas do modelo cultural difusionista que, nos campos do conhecimento, estabelecem critérios de valor para que o "diferente" seja tomado como inferior. Esse modelo tem como reflexo a busca de muitos pela adaptação, além disso a hierarquização a partir das diferenças é geradora de frustrações, na medida em que o estudante pode elaborar a imagem de si como alguém inferior, já que não é iniciado nessa cultura, pois

[...] além de construir e transmitir uma experiência "objetiva" do mundo exterior, [a cultura constrói e transmite] também a experiência que as pessoas têm de si mesmas e dos outros como "sujeitos". Ou, em outras palavras, tanto o que é ser pessoa em geral como o que para cada uma é ser ela mesma em particular (Larrosa,1994, p. 9-10).

sendo que tanto a formação como a transformação de atitudes operam a partir de elemento cognitivo, afetivo e de conduta. Atitudes são transmitidas e previsíveis em relação à conduta social, todavia, "não são os únicos fatores que intervêm na decisão tomada por uma pessoa, a agir de uma maneira determinada".

${ }^{21}$ BOURDIEU, P. Ce que parler veut dire. Paris: Fayard, 1982.

POUZARGUE, F. L'arbre à palabres. Paris: William Blake and Co Art \& Arts, 1998. 
Portanto, embora democratizar o acesso ao ensino superior seja essencial, para a participação mais ampla das pessoas nos processos do conhecimento é necessário ultrapassar essa perspectiva. Assim, colocamos em causa a diferença como critério constitutivo da cultura científico-acadêmica, tomando as inter-relações entre sujeitos e a ordem simbólica como definidoras dessa cultura. Desta forma a diferença passa a ser uma categoria geradora da própria cultura científico-acadêmica, propulsora de transformações da ordem simbólica, na medida em que a interculturalidade (GARCÍA CANCLINI, 2009) seja considerada constitutiva não apenas das relações sociais, mas também das relações culturais. Pautar as relações produtoras de sentido na diversidade e diferença demanda um olhar atento e rigoroso à reelaboração dos próprios dispositivos da educação superior, dentre os quais a biblioteca universitária.

Essa perspectiva leva a interrogar as relações com o saber ${ }^{22}$ e o saber-fazer ${ }^{23}$ implicadas na cultura científico-acadêmica. Se caracterizarmos essa cultura a partir da interculturalidade, da busca por ideias bem fundamentadas acerca do mundo, pela imparcialidade e pelo diálogo crítico (BARNETT, 2014), é essencial que desenvolvamos dispositivos para a formação dos estudantes nessa direção. Se a cultura científico-acadêmica efetivamente compreende o conhecimento como construção, há que se interrogar quais experiências promove no âmbito das inter-relações dos estudantes com o patrimônio infodocumental: se objetivam a produção de sentido ou a assimilação de conteúdos intelectuais tomados como verdades transmitidas.

Busca-se, portanto, romper com abordagens da cultura científico-acadêmica que a veem como um circuito prioritário para os iniciados numa cultura dominante.

A questão tem sua relevância acentuada na medida em que se inscreve no quadro de um país que não desenvolve a contento processos de socialização da ciência em termos mais amplos. Contudo, se ciência e tecnologia delimitam cada vez mais nosso cotidiano, dispor de meios para compreender seus processos é essencial à participação afirmativa dos sujeitos no mundo (VOGT, 2003). Assim, a educação

\footnotetext{
${ }^{22}$ Conforme Charlot (2008, p. 81), "a relação com o saber é o conjunto das relações que um sujeito mantém com um objeto, um 'conteúdo de pensamento', uma atividade, uma relação interpessoal, um lugar, uma pessoa, uma situação, uma ocasião, uma obrigação, etc., ligados de uma certa maneira com o aprender e o saber; e, por isso mesmo, é também relação com a linguagem, relação com o tempo, relação com a ação no mundo e sobre o mundo, relação com os outros e relação consigo mesmo enquanto mais ou menos capaz de aprender tal coisa, em tal situação."

${ }^{23} \mathrm{O}$ saber-fazer (savoir-faire) é o conhecimento prático sobre como executar alguma tarefa ou solucionar um problema prático. Isto é, a capacidade de empregar conhecimento para realizar uma tarefa com êxito (SABER-FAZER, s.d.).
} 
superior (e sua cultura) é um elemento central à formação de uma cultura científica ${ }^{24}$ no país, essencial para que os cidadãos participem afirmativamente dos dinâmicos processos culturais nos quais estão presentes a ciência e tecnologia, pois o processo que envolve o desenvolvimento científico é:

um processo cultural, quer seja ele considerado do ponto de vista de sua produção, de sua difusão entre pares ou na dinâmica social do ensino e da educação, ou ainda do ponto de vista de sua divulgação na sociedade, como um todo, para o estabelecimento das relações críticas necessárias entre o cidadão e os valores culturais, de seu tempo e de sua história (VOGT, 2003).

Desta maneira, a proposta em causa representa possibilidades de (re)elaboração da ordem simbólica que circula em meio à cultura científico-acadêmica e exerce um papel fundamental sobre a vida cultural, política e econômica das sociedades. Para tanto, compreende a necessidade de problematização e reelaboração dos dispositivos da educação superior, dentre os quais a biblioteca universitária, circuito privilegiado das relações com o patrimônio infodocumental.

\section{2 (RE)ELABORAR A EXPERIÊNCIA DE SI NA CULTURA CIENTÍFICO-ACADÊMICA}

O sujeito caracteriza-se por certas formas de relação consigo mesmo; formas essas histórica e culturalmente definidas, que delimitam a experiência de si. Quando o sujeito se observa, decifra, julga, narra, interpreta, domina, enfim, quando faz algo consigo mesmo está se produzindo no interior de práticas que, por sua vez, guardam relação direta com aquilo que lhe é exterior. Com isso, a experiência de si é algo que se transmite e aprende, sendo justamente na articulação de discursos e práticas (pedagógicas, culturais, terapêuticas, etc.) que o sujeito se (re)elabora naquilo que é (LARROSA, 1994). Ou seja, as relações que se têm com o meio são definidoras da experiência de si, assim como toda cultura transmite "um certo repertório de modos de

\footnotetext{
${ }^{24}$ Vogt (2003) argumenta que a cultura científica engloba o fazer científico e o artístico, pois "embora haja distinções teóricas e metodológicas fundamentais entre arte e ciência", ambas têm como finalidade em comum "a criação e a geração de conhecimento, através da formulação de conceitos abstratos e ao mesmo tempo, por paradoxal que pareça, tangíveis e concretos. No caso da ciência essa tangibilidade e concretude se dá pela demonstração lógica e pela experiência; no caso da arte, pela sensibilização do conceito em metáfora e pela vivência".
} 
experiência de si, e todo novo membro de uma cultura deve aprender a ser pessoa em alguma das modalidades incluídas nesse repertório" (LARROSA, 1994, p.9-10).

Portanto, aquilo que a cultura científico-acadêmica oferece, enquanto possibilidades de elaboração da experiência de si, compõe contornos da imagem que o estudante constrói dele mesmo nesse circuito. Essa elaboração se dá em meio a lógicas que se entrecruzam e conferem um sentido subjetivo a esse processo ao serem interiorizadas pelo sujeito em dinâmicas que compreendem sua singularidade (DUBET, 2008). Assim, uma vez que é do encontro entre sujeito e cultura que se constitui a experiência de si, os deslocamentos para novos territórios culturais provocam transformações na percepção que o sujeito tem de si.

Dada a centralidade do binômio informação e conhecimento na educação superior, cabe discutir a experiência do estudante de graduação no domínio das relações com a ordem simbólica que aí circula. Posto que somos seres de palavras - ampliados em nossa presença no mundo a partir das relações que estabelecemos com essa ordem simbólica, produzindo sentidos - , o ingresso no mundo universitário implica possibilidades de que o estudante se relacione com informação científica e conhecimento acadêmico, (re)elaborando uma relação reflexiva consigo mesmo como sujeito de conhecimento. A experiência que o estudante estabelece com os dispositivos da cultura científico-acadêmica é experiência com a própria ordem simbólica, definidora de suas interações com o mundo. Portanto, a problemática da reelaboração da experiência de si na cultura científico-acadêmica, implica considerar a biblioteca universitária como um dos dispositivos centrais das relações com essa ordem, dado que nesse circuito a matéria simbólica é questão central.

No contexto atual, em que as relações com o universo simbólico vão sendo fortemente delineadas a partir de perspectivas de consumo de informações - como vimos na seção 2.1 -, somadas à precariedade da educação básica brasileira, evidenciase os contornos de um cenário a ser enfrentado para que se dê a participação crítica e criadora dos sujeitos no mundo.

O início do curso de graduação, além de delimitar o ingresso em uma nova cultura, corresponde a um momento de transformações na vida do sujeito em sua relação consigo mesmo. Grande parcela dos ingressantes em cursos de nível superior está em transição da adolescência para a vida adulta, fase marcada por novas demandas de aprendizado: as experiências passam a exigir maior grau de autonomia, questões profissionais apresentam-se de maneira mais relevante - independentemente da faixa 
etária -, muitos saem da casa dos pais, dentre tantos outros elementos determinantes de uma nova experiência na vida do sujeito (BELLETATI, 2011).

Somado a isso, há a percepção do próprio estudante da necessidade de novas formas de relação com a informação e o conhecimento, em meio a um quadro de possíveis dificuldades impostas por demandas tais como: saber articular as informações recebidas em sala de aula e nos textos; saber articular os saberes das diferentes disciplinas do curso; saber ler, escrever, pensar crítica e autonomamente; ingressar no mundo das ideias como sujeito (saber pensar); saber elaborar fichamentos, sínteses e resumos; saber fazer seminários; saber fazer anotações dos conteúdos apresentados em sala de aula; saber realizar pesquisas; saber usar a biblioteca; saber normalizar trabalhos acadêmicos, etc.

A compreensão e apropriação do vocabulário e ordenamentos constitutivos da nova cultura também se apresenta como uma questão problemática para muitos (exemplos: matéria versus disciplina, disciplinas optativas e eletivas, créditos, iniciação científica, fichamento, resumo, síntese, ensaio, artigo científico, monografia, universidade, instituto, faculdade, escola, departamento, etc.). Além disso, saber identificar tarefas a realizar, ser autônomo nos estudos, não ter postura passiva aguardando exclusivamente um passo-a-passo do professor sobre o que ler, o que fazer, como elaborar atividades para iniciá-las -, assim como a mobilização para os estudos, ou seja, ter objetivos com os estudos, ter um propósito que dá sentido ao ato de estudar, conferindo sentido - inscrito na vida e expectativas do sujeito - às atividades exercidas enquanto estudante, constituem um rol de elementos que causa estranhamento para muitos que ingressam na educação superior.

O fenômeno é recorrente em diferentes contextos. Em pesquisa qualitativa realizada na França sobre a relação com a cultura científico-acadêmica, Coulon (2008) expôs que, embora continue sendo estudante, o sujeito depara-se com uma nova realidade em que é preciso aprender a organizar o programa de aulas e escolher disciplinas. Conforme o autor, as aulas possuem outra duração, a distribuição de disciplinas é diversa da praticada no ensino básico, os estudos exigem uma nova relação com o tempo. Ao encontro da pesquisa francesa, Belletati (2011), em estudo qualitativo sobre evasão de cursos de graduação na USP, inferiu que a organização do tempo é questão problemática tanto para estudantes trabalhadores quanto não-trabalhadores, pois, mais que ter tempo livre, está em causa a capacidade de organização para os estudos e a exigência de concentração nas atividades. A autora trouxe relatos de 
estudantes que evidenciaram a necessidade de aprender a concentrar-se para uso satisfatório do tempo disponível, assim como de saber organizar as atividades em um cronograma. Há uma liberdade desconhecida até então pelo universitário que, no entanto, tende a buscar referenciais em sua trajetória pretérita, marcadamente distinta.

Além de questões de ordem formal, tais como usar o tempo livre, priorizar escolhas, etc., as relações com determinado tipo de informação e conhecimento constituem grande empecilho para muitos. Segundo Coulon (2008), se o novo meio coloca os estudantes diante da necessidade de estabelecer novas formas de relações com as regras, ele impõe, sobretudo, novos princípios de diálogo com o saber, para os quais os mesmos nem sempre estão preparados.

Adachi (2017), ao realizar pesquisa sobre evasão de universitários de cursos de graduação da USP, entrevistou um estudante que relatou que, em sua trajetória no ensino, o curso de graduação foi o auge da sua decadência, pois, se no ensino fundamental considerava-se um bom aluno, com o tempo foi desinteressando-se pelos estudos a ponto de abandonar o curso superior. Aquilo que para muitos poderia ser considerado uma marca de sucesso na trajetória de ensino - ingressar numa universidade pública -, para esse estudante significou experiência negativa - marcada pelo termo decadência -, na medida em que não lhe foi possível apropriar-se do meio acadêmico de modo geral. Assim, além do aprendizado de conteúdos intelectuais, na educação superior está em causa a necessidade de aprender certas formas de relação com o patrimônio simbólico, como condição à integração crítica e criadora dos sujeitos à cultura científico-acadêmica e aos campos do conhecimento.

Esse aprendizado não se desenvolve a partir da simples inserção num ambiente privilegiado de informação e conhecimento, como é o caso das instituições de ensino superior. Embora essenciais, aprendizagens dessa ordem geralmente estão à margem do processo de ensino, que se volta majoritariamente aos conteúdos intelectuais das diferentes áreas do conhecimento. A apropriação do meio, grosso modo, é tomada como algo natural, nem sempre se caracterizando como questão que envolve, além da tomada de consciência, formas objetivas de ação sobre o problema. Assim, indagações como - "Quem sou eu em relação a esse conjunto? Qual minha função e relação com a instituição? Como eu me integro a essa cultura, marcada por práticas específicas?” não são apenas conjecturas existenciais, pois ensejam perspectivas metodológicas concretas para que os estudantes se sintam autorizados e aptos para esse encontro com a simbolosfera. 
Conforme Dubet (2008), se os sentidos, os princípios, os mecanismos e os modos de apropriação do meio não se apresentam de maneira clara para o estudante, haverá um problema no âmbito da atribuição de significado à sua experiência e ao seu papel na cultura científico-acadêmica. Em face disso, embora o ingresso na educação superior configure meio para (re)elaboração dos limites do próprio ser, são essenciais dispositivos que posicionem e situem o estudante como sujeito afirmativo dessa cultura.

Portanto, para discutir possibilidades de reelaboração das relações dos estudantes com o patrimônio cultural, é importante problematizar as representações de estudante e de conhecimento a partir das quais a biblioteca universitária opera, na medida em que se trata de instância de mediação entre estes e a ordem simbólica.

A ordem simbólica está diretamente atrelada a dinâmicas socioeconômicas e culturais; sobretudo numa sociedade desigual como a nossa, em que o conhecimento “traça múltiplas linhas divisórias entre aqueles que o detêm e aqueles que aspiram a possuí-lo, entre aqueles que o compartilham e aqueles que mantêm seu monopólio, entre aqueles que reconhecem ou negam seu status e validade" (JACOB, 2007, p. 125, tradução nossa), para muitos a educação superior pode configurar experiência marcada por frustrações, caso não sejam desenvolvidas ações efetivas que possibilitem ao sujeito (re)elaborar-se como estudante universitário.

Se, conforme Vigotsky (2001, p.289), "perceber as coisas de modo diferente significa ao mesmo tempo ganhar outras possibilidades de agir em relação a elas", a dimensão ora apresentada é essencial para que a experiência do estudante seja a de alguém que (re)elabora a si mesmo e ao próprio meio, ampliando sua esfera de presença na cultura científico-acadêmica, nos campos do conhecimento e, portanto, no próprio mundo.

\subsection{1 (Re)elaborar-se como forma de pertencimento}

Pertencer é uma noção subjetiva que, de acordo com Jesus (2018), gera sentimento de integração: a percepção de si como sujeito que se transforma em meio a um circuito, mas que também pode transformá-lo. Implica, então, a noção de responsabilidade e uma dimensão identitária essencial a ser considerada, na medida em que "aprender faz sentido por referência à história do sujeito, às suas expectativas, às 
suas referências, à sua concepção da vida, às suas relações com os outros, à imagem que tem de si e à que quer dar de si aos outros" (CHARLOT, 2008, p. 72).

Assim, pertencer à cultura científico-acadêmica implica a (re)elaboração de si como alguém capaz de se apropriar do patrimônio simbólico, em especial o infodocumental, o que por sua vez demanda estruturas para interações nessa direção. $\mathrm{O}$ ingresso na cultura científico-acadêmica coloca o sujeito face à necessidade de dar sentido a si mesmo como estudante universitário, como alguém que pertence ao meio. Para tanto, é essencial que experimente uma relação específica com o meio que o vincule, mas também o posicione, que lhe permita atribuir um lugar para si nessa esfera, mas também no tempo e na memória cultural (JACOB, 2002). Há que se considerar, portanto, que essa relação é de um sujeito desejante, pois o desejo está na base da mobilização das pessoas, é a força propulsora que permite reunir recursos internos para se (re)elaborar (CHARLOT, 2008). Pertencer é condição que implica a diferença como categoria constitutiva da cultura científico-acadêmica, essencial à consideração das singularidades dos sujeitos. Em outros termos, está em causa compreender o estudante como alguém que se relaciona com o meio em trocas mútuas e não como alguém a ser incorporado em perspectiva homogeneizadora.

Portanto, se a noção de Eu é "produto dos ajustamentos que se realizam através do papel desempenhado pelo indivíduo nas relações com os outros" (CAUNE, 2006, p. 68), é válido encarar a educação superior como "Os outros". E, então, interrogar em que medida seus dispositivos propiciam ao sujeito relações com os elementos que integram esse complexo universo - em especial o patrimônio simbólico que o caracteriza -, que mobilizem uma experiência de si como pertencente ao meio. Em nosso estudo, a questão é direcionada especificamente às bibliotecas universitárias, indagando-nos acerca das relações com a informação e o conhecimento que esse "Outro" representado pela biblioteca - proporciona aos estudantes.

Conforme anteriormente sinalizado, a experiência do estudante na educação superior pode ser a de alguém que não atribui a si a identidade de pertencente ao meio, uma vez que esse sentido é construído a partir dos vínculos concretos ou simbólicos estabelecidos com determinado universo. A depender das situações e contextos, para alguns a imagem de si é de um indivíduo não autorizado a integrar afirmativamente esse circuito, questão diretamente atrelada às desigualdades da ordem socioeconômica.

Embora em nosso país existam meios de ingresso do sujeito na universidade vestibular, nota obtida no Exame Nacional do Ensino Médio (ENEM) -, validando para 
a IES sua capacidade, o peso simbólico da autorização subjetiva para pertencimento ao meio nem sempre acompanha o êxito nos exames de seleção, comprometendo as relações com a nova cultura.

É o que demonstrou a Estudante $\mathrm{A}^{25}$, ao dizer que "mesmo eu tendo passado no vestibular, a USP, a biblioteca, os espaços não era uma coisa que eu achava que era lugar para uma pessoa como eu, eu não achava que eu poderia ocupar aqueles espaços".

O constrangimento da estudante em autorizar-se a ocupar tais espaços, de um lado, está atrelado à percepção de dificuldades em se relacionar com informação científica e conhecimento acadêmico, abordada mais adiante; de outro, revela barreira inscrita na ordem socioeconômica, pois, conforme também afirmou "de repente você está sentada tendo aula do lado de alguém que estudou em escola que a mensalidade é 3 mil reais".

O lugar simbólico que o indivíduo ocupa articula-se também ao lugar social concreto, afetando comportamentos, envolvendo tanto aspectos singulares dos sujeitos como aspectos plurais e comuns do mundo (PERROTTI; PIERUCCINI, 2014). Nesses termos, o estudante poderá representar a si mesmo como não pertencente ao meio já que, em grande medida, projeta sua experiência na educação superior a partir do sistema de práticas e disposições de sua educação e grupo social precedentes, nem sempre consciente de que, assim como a experiência de si é contingente, esse sistema de disposições é flexível e dinâmico.

A fala desta estudante vai ao encontro da experiência de outros. Tinto (1993), ao realizar pesquisa no contexto estadunidense, argumenta que os primeiros semestres são bastante difíceis para muitos estudantes, especificamente aqueles oriundos de camadas socioeconômicas desfavorecidas, em razão do aprofundamento do fosso entre a cultura de origem e a cultura científico-acadêmica. O ingresso na educação superior pode, então, configurar para muitos a sensação de deslassamento (HOGGART, 1973). Ou seja, sentimento que acomete àqueles que, pertencentes a meios populares, alcançam a oportunidade de ingressar em circuitos escolares de classes mais abastadas, mas experimentam grande desconforto (físico e emocional), ficando a "meio caminho", perdidos entre duas culturas: distanciam-se de sua cultura de origem, mas também não têm elementos para participar efetivamente da nova cultura científico-acadêmica.

\footnotetext{
${ }^{25}$ Neste capítulo são trazidas falas de estudantes (designados pelo termo estudante seguido por uma letra) que participaram da parte empírica desta pesquisa, detalhada na seção 1.1. Metodologia.
} 
Nessa perspectiva, o ingresso num curso superior, mesmo que seguido por sua conclusão, nem sempre será acompanhado pelo sentimento de pertencimento àquele circuito, apesar do desejo de desenvolvê-lo. Conforme Araújo e Oliveira (2014), esse sentido não será alcançado por muitos sujeitos por não acreditarem que aquele meio é também para eles, justamente porque na experiência pretérita não encontram elementos que justifiquem para si tal vinculação.

A importância da questão é acentuada quando compreendemos que essa percepção de não pertencimento ao meio corresponde à percepção de não fazer parte do processo do conhecimento, esse modo de intervenção no real. Além de ser percepção mais recorrente entre aqueles de camadas socioeconomicamente menos favorecidas, também perpassa muitos indivíduos que integram um quadro sociocultural nãodominante, às margens desse circuito do conhecimento acadêmico.

Em face da problemática, a educação superior integra preocupações que extrapolam aspectos unicamente de ordem cognitiva, em relação ao despreparo do estudante para acompanhar o curso. Criar possibilidades para que o sujeito (re)elabore a si mesmo como pertencente ao meio, a partir de práticas capazes de mobilizar a configuração de uma nova subjetividade entendida como "síntese entre o novo que se experimenta e os conteúdos subjetivos já configurados até então" (TEIXEIRA, 200326, apud ARAÚJO; OLIVEIRA, 2014), mostra-se questão central para sua inserção no universo acadêmico.

Tinto (1993) já expôs a intrínseca relação entre experiências de aprendizagem e o abandono dos cursos de graduação. Enquanto instância de transmissão e (re)produção de um sistema de conhecimento, para muitos estudantes, a educação superior irá demandar a aprendizagem de usos de um mundo simbólico que, conforme Charlot (2008), não parece ter sido organizado em seu favor.

A Estudante B revelou perceber-se em meio a essa problemática, ao expor que “eu não tive muitos aprendizados que são requeridos no ensino superior, eu não sabia o que...exatamente de onde tirar esse aprendizado. E isso é pouco difícil”. A fala da estudante ingressante - um relato sobre aquilo que mobilizou sua participação nas atividades referentes à parte empírica deste estudo - evidencia desejo de que a educação

\footnotetext{
26 Teixeira, L. C. Sentido subjetivo da exploração sexual para uma adolescente prostituída. In: Ozella, S. (Org.). Adolescências construídas: a visão da psicologia sócio-histórica. São Paulo: Cortez, 2003. p. 105-136.
} 
superior disponha de dispositivos que a propulsionem em relações com o patrimônio infodocumental, dada a dificuldade em delinear, por si só e a partir das dinâmicas de sala de aula, novas formas de relação com esse patrimônio.

Diante disso, a elaboração da experiência de si como pertencente à cultura científico-acadêmica implica, ao que nos parece, mediações que tomem o estudante como ser de significados que interage com o patrimônio simbólico em trocas mútuas, construindo dialogicamente referenciais para tanto. Por sua natureza complexa, multi e interdisciplinar, a biblioteca universitária ultrapassa limites disciplinares e está livre de constrangimentos definidos para a progressão formal do estudante. Tal aspecto the confere liberdade para atuar a partir de projeto próprio que considere a produção do sentido do conhecimento em todas as fases do processo de relação do estudante com o patrimônio infodocumental. Ou seja, a produção de sentidos não é objetivo, não está na linha de chegada, ela é ponto de partida a ser considerado em práticas educativas que visam o pertencimento cultural dos estudantes.

\subsection{2 (Re)elaborar-se como estudante}

O ingresso na educação superior coloca o sujeito face à demanda por novas formas de relação com um sistema ordenado de conhecimento. O idioma francês é rico para ilustrar a questão, pois o ofício de estudante, no âmbito da educação formal, distingue-se pelo emprego do termo élève(e) (aluno/a), utilizado para designar crianças e jovens que estudam até o nível médio, e étudiant(e) (estudante) para caracterizar aqueles que ingressam no ensino superior. Conforme a etimologia dos termos, élever significa instruir, desenvolver, dar educação. Já elève(e) seria a pessoa elevada a uma nova posição por meio das lições, instruções recebidas. Por sua vez, étudiant(e) indica a pessoa que estuda, sendo que étudier - estudar - significa pesquisar para adquirir um conhecimento, buscar compreender por meio do exame, da observação atenta (ÉLÈVE, s.d.; ÉTUDIANT, s.d.), envolvendo maior autonomia na relação com o conhecimento. A distinção, operada no âmbito da linguagem, sinaliza para papéis e atitudes diversos, indicando que na educação superior é esperado que a relação com o patrimônio simbólico implique alguém que é sujeito da ação. Assim, são requeridas novas atitudes, bem como saberes e fazeres do estudante em sua relação com a informação e o 
conhecimento que circulam e são produzidos num meio que lhe é novo, formado a partir de regras, mecanismos, lógicas e princípios constitutivos específicos.

Posto que abordamos a cultura científico-acadêmica a partir das interações que nela se realizam, privilegiando a problemática de um sujeito de palavra que se interrelaciona com esse meio e assim se elabora (CAUNE, 2006), cabe-nos interrogar a ordem de relações do estudante com o patrimônio simbólico para assim buscar extrair elementos que levem à problematização do papel da biblioteca universitária. Isto porque, compreender questões implicadas na relação do estudante com a informação científica e o conhecimento acadêmico, é meio privilegiado para repensarmos o modelo comunicacional adotado pela biblioteca universitária.

De acordo com Adachi (2017), em pesquisa já referida sobre evasão de estudantes de cursos superiores, dentre aqueles que desistiram da graduação, havia os que afirmaram "não saber estudar", revelando que não se consideravam integrantes do meio, dada sua percepção do não domínio de formas para relações afirmativas com informação/conhecimento nesse circuito.

Para a Estudante C, que já havia cursado uma primeira graduação na Faculdade de Filosofia, Letras e Ciências Humanas da USP e iniciava a segunda, há

um abismo entre a escola pública e a universidade, muita diferença, o primeiro ano é um choque, principalmente o primeiro semestre, você tem que correr mais atrás das coisas, você não sabe formato de nada, você vai aprendendo aos trancos e barrancos, [...] eu não tive alguém para dizer assim é nesse formato, eu quero ensaio e ensaio tem esse formato, a gente ia se virando, consultando, procurando fazer o que você achava que estava certo.

Assim, o estudante pode finalizar a graduação sem considerar que se (re)elaborou como sujeito que trava relações afirmativas com o par informação/conhecimento. Conforme o Estudante E, que também já havia cursado outra graduação, em Meteorologia na USP, seu interesse em participar das atividades relativas à parte empírica desta tese se deu em razão de "me compreender melhor, mas, compreender esse mundo [a universidade] melhor, a metodologia envolvida".

Na mesma direção, a Estudante D afirmou que "talvez a forma que me foi ensinado o ato de pesquisar, de estudar, sempre foi de forma muito fragmentada [...] então eu gostaria muito de aprender a me aprofundar, a pesquisar e aprender coisas 
novas", evidenciando seu desejo de dispor de saberes para se relacionar com a complexidade dessa ordem simbólica.

A formação na educação básica não corresponderá necessariamente a um sujeito já pronto para relações afirmativas com informação científica e conhecimento acadêmico na educação superior. $O$ ingresso nesse novo universo evidencia demanda por certa autonomia intelectual dos estudantes. O desenvolvimento da autonomia intelectual não corresponde a uma construção solitária de um sujeito que, como disse a Estudante $\mathrm{C}$, buscou ir "se virando [...] procurando fazer o que você achava que estava certo”, sem dispor de mecanismos de mediações que dessem respostas a suas necessidades e desejos de conhecimento. Encarar a construção da autonomia intelectual nessa perspectiva seria incorrer numa espécie de laissez-faire simbólico, isentando os dispositivos da educação superior da responsabilidade de acolher os sujeitos em suas investidas e dinâmicas de relação com o patrimônio cultural.

As falas são indicativas de que abordagens focadas exclusivamente na disponibilidade de um patrimônio simbólico ou que busquem enquadrar o sujeito em um meio com suas regras próprias, desconsiderando a esfera da produção de sentidos, são insuficientes à participação dos estudantes no processo do conhecimento. $\mathrm{O}$ fundamental diálogo dos estudantes com o patrimônio infodocumental, essencial aos processos de construção de conhecimento e significação, coloca a biblioteca universitária em posição privilegiada e estratégica como categoria de mediação cultural e forma indispensável à apropriação da ordem simbólica.

Coulon (2008) evidencia relatos de estudantes que sinalizam para dificuldades com a natureza do trabalho intelectual implicado no ensino superior. Na medida em que os professores não mostram caminhos explícitos para serem seguidos rotineiramente, muitos aguardam orientações para desempenhar alguma atividade, não aproveitando o tempo livre para se lançarem de forma autônoma sobre o patrimônio infodocumental.

Em face disso, estaria em causa na formação do estudante a incorporação de "novas formas de solucionar problemas ao repertório de atividades intelectuais" (LURIA, 1988, p. 44), dentre as quais a autonomia intelectual, esse "processo de decisão e de humanização que vamos construindo historicamente, a partir de várias, inúmeras decisões que vamos tomando ao longo de nossa existência” (MACHADO, 2008, p. 57).

Nessa mesma esfera de questões, em contexto francês, Coulon (2008, p. 259) aponta dificuldades dos estudantes em fazer sínteses dos conhecimentos apresentados 
em curso, sendo que muitos têm dificuldades em reconhecer aquilo que é importante anotar durante uma aula: "não é raro, depois de duas horas de aula, ver escritas algumas linhas de anotações, que nem sempre correspondem aos aspectos mais importantes que foram tratados". Evidência de que a capacidade de extrair os principais elementos das informações recebidas em aula não foi, de modo geral, desenvolvida a contento. $\mathrm{O}$ Estudante F relatou experiência nessa direção ao dizer que "[anotações durante a aula] é uma coisa que eu não fazia no fundamental e no ensino médio não fazia também. Era só o que estava na lousa [que eu anotava] e foi mais no cursinho e aqui que comecei a anotar o que o professor falava”.

Por sua vez, Belletati (2011) apontou que as relações entre professor, estudante e conhecimento também passam a adquirir novos contornos na graduação, pois o conteúdo não é mais "mastigado", conforme relato de estudante entrevistado pela pesquisadora. Além de conteúdos intelectuais distintos, o sistema de conhecimento em causa na graduação coloca o sujeito diante de todo um repertório informacional constituído a partir de lógicas específicas que, muitas vezes, ele não domina, em especial a linguagem dos textos científicos, dos ensaios acadêmicos, para os quais não basta saber ler e escrever.

Mais que o aprendizado de conteúdos intelectuais ou a formação numa dada área do conhecimento, para a (re)elaboração de si como estudante universitário são demandadas práticas que compreendam o desenvolvimento da metacognição, caracterizada como a capacidade de refletir e controlar os próprios processos cognitivos. De acordo com Remond (2011), a metacognição inclui conhecimento sobre por que, como e quando se envolver em variadas atividades cognitivas e possui duas dimensões relacionadas: o conhecimento metacognitivo - que compreende conhecimentos declarativos, processuais e condicionais - e o controle metacognitivo - que inclui planejamento de atividades, autoavaliação e possível revisão da estratégia implementada; dimensões passíveis de serem ensinadas e, portanto, aprendidas ${ }^{27}$. Na

27 Remond (2011, não paginado, tradução nossa) explica a metacognição, conforme segue: "Somos capazes de declarar regras, propriedades, teoremas ou até citar ações a serem executadas para resolver uma tarefa, uma dificuldade. Por exemplo, você pode reler uma parte de um texto para lhe ajudar em dado contexto ou consultar um dicionário quando encontrar uma dificuldade de compreensão relacionada a uma palavra. Nesse caso apelamos aos nossos conhecimentos declarativos, traduzidos como saber "o que fazer". Na próxima fase, procurar a palavra no dicionário, revela-se como o resultado de uma série de procedimentos que permitem selecionar o sentido pertinente da palavra, então, é preciso integrar os sentidos para construir a significação do texto. Esse encadeamento de ações exige conhecimentos processuais. É também importante saber quando e por que usar essa ou aquela estratégia para selecionar a mais adequada, isto é designado sob o termo conhecimentos condicionais. Esses conhecimentos se 
medida em que corresponde a ter conhecimento sobre motivos, modos e momentos de empreender determinada atividade cognitiva, a metacognição é condição à produção de sentidos e participação afirmativa no processo do conhecimento.

A metacognição diz respeito, portanto, ao domínio da relação entre consciência e significação no âmbito da ordem simbólica externa ao sujeito. Segundo Freire (KRONBAUER, 2017, p. 87), enquanto experiência interpretada a consciência caracteriza-se por sua intencionalidade e revela certos "graus de compreensão da realidade", os quais permitem divisar uma consciência intransitiva, uma transitiva ingênua e outra transitiva crítica. Essas considerações indicam que a condição do ser humano imerso em sua realidade e não dispondo da capacidade de objetivá-la é denominada intransitividade da consciência, ou seja, consciência dos seres humanos “cuja 'vida é mera biologia', que ainda não se fez biografia”. Já a consciência transitiva ingênua corresponde à percepção de contradições sociais, mas inscreve-se em circuito conformista, fora das esferas da investigação e compreensão das causas dos fenômenos que marcam os contextos sociais, culturais e econômicos. Esta caracteriza-se por uma interpretação simplificadora dos problemas, por satisfazer-se com explicações redutoras ou fabulosas, por guiar-se pela emoção em meio a dificuldades de desenvolvimento e compreensão da argumentação racional.

Desenvolver a capacidade para o diálogo, para argumentar racionalmente sobre situações e problemas, é o caminho para alcançar a consciência transitiva crítica, caracterizada pela profundidade com que o indivíduo avalia e interpreta diferentes situações, por meio do pensar autônomo e comprometido, o que culmina no seu engajamento enquanto sujeito do mundo. A consciência transitiva crítica considera princípios rigorosos e relações causais para interpretar a realidade. É dialógica, marcada pela disposição de rever posturas e preconceitos que podem formar sua interpretação do mundo e de seus fenômenos sendo, portanto, consciência de sujeitos que se responsabilizam por seus atos. Assim, à (re)elaboração de si como sujeito com

relacionam ao conhecimento do papel e das condições de aplicação das estratégias, de acordo com os objetivos a serem alcançados e o contexto. Assim, quando identificamos analogias entre duas situações, esses conhecimentos permitem se relacionar com uma classe de situações conhecidas e mobilizar, na situação similar, as estratégias já implementadas. Esses três tipos de conhecimento - declarativos, processuais, condicionais - correspondem aos conhecimentos metacognitivos, um dos dois componentes da metacognição. O outro componente, o controle metacognitivo, inclui três etapas: planejamento de atividades, autoavaliação de sua eficácia durante a tarefa e possível revisão da estratégia implementada, levando ao seu ajuste. Esse controle produz informações sobre as atividades cognitivas atuais e ativa estratégias metacognitivas". 
consciência transitiva crítica é demandada uma educação em que a metacognição, tendo em vista a capacidade de decidir, fazer escolhas de ação conscientes - em diálogo com perspectivas de desenvolvimento de um mundo partilhado por todos - , seja desenvolvida.

O risco de que muitos estudantes estacionem na consciência transitiva ingênua é grande, sobretudo considerando os fluxos informacionais contemporâneos - que se apresentam no contexto social mais amplo marcado pelas TIC e redes sociais digitais inscritos, em grande parte, num modelo comunicacional delineado sob a perspectiva do consumo simbólico. Nesse sentido, caberia interrogar qual o modelo comunicacional que norteia os dispositivos da educação superior, já que a (re)elaboração de si como estudante implica considerar as lógicas que regem as mediações promovidas por esses dispositivos.

Face ao problema, no âmbito da biblioteca universitária é preciso problematizar o modelo comunicacional que esta tem adotado, pois o desenvolvimento da consciência crítica demanda modelos que considerem a esfera das significações e as mediações culturais como produtoras de sentido. Considerando que a autonomia intelectual assim como a consciência crítica do sujeito guardam intrínseca relação de dependência com o patrimônio cultural, as mediações promovidas nesse domínio serão definidoras de possibilidades de formação de alguém que, conforme Charlot (2008), argumenta, experimenta, verifica, tem vontade de provar, demonstrar, validar. Portanto, de um sujeito que toma partido da Razão e do saber em suas relações com o mundo e a simbolosfera.

A questão dá margens para redimensionar o foco de atuação da biblioteca universitária, atualmente centrado nas dinâmicas de organização de um universo simbólico já constituído, para as dinâmicas de sua produção, considerando os estudantes como sujeitos desse processo. Trata-se de pensar seu domínio de ação tanto na ordenação e acesso à ordem simbólica, quanto no âmbito das práticas que articulem relações do estudante com o patrimônio infodocumental.

\subsection{3 (Re)elaborar-se como alguém dotado de curiosidade epistemológica}

A curiosidade, essa "necessidade ontológica que caracteriza o processo de criação e recriação da existência humana" (FREITAS, 2017, p. 107), é dimensão 
essencial do ato de conhecer. Contudo, no que tange à produção de conhecimento acadêmico não está em causa a curiosidade "desarmada" com que se olha as ondas do mar ou as nuvens do céu. Conforme Paulo Freire (199328 apud FREITAS, 2017, p. 108), o processo de conhecimento implica um sujeito dotado de curiosidade epistemológica, própria da consciência crítica. A curiosidade epistemológica é metódica e exigente, afasta-se de seu objeto para então se aproximar buscando conhecê-lo, é rigorosa e tem por base a Razão, fundante da autonomia intelectual do ser.

Assim, de um lado, o conhecimento pressupõe um sujeito curioso, dimensão intrinsecamente relacionada aos seus desejos e necessidades, à sua esfera de significações. De outro, requer uma curiosidade dotada de rigor e de método.

O método é aqui compreendido não como conjunto de fórmulas para alcançar um resultado previsto, mas enquanto disciplina do pensamento, algo que ajuda o sujeito a elaborar estratégias cognitivas, "situando e contextualizando suas informações, conhecimentos e decisões, tornando-o apto para enfrentar o desafio onipresente da complexidade". (MORIN, 2003, p. 12-13). Na curiosidade epistemológica está em causa o método como construção dotada de rigor, noção que, ao evidenciar a complexidade da realidade, consiste na utilização dos instrumentos disponíveis para que os sujeitos a compreendam, atuando de forma crítica e criadora (STRECK, 2017).

A curiosidade epistemológica é condição necessária à consciência crítica, na medida em que possibilita ao sujeito lançar-se em inter-relações com o mundo e seus fenômenos de forma criteriosa, pressupondo sua esfera de significados e mobilizações. Portanto, é essencial às negociações culturais (OLIVEIRA, 2014) entre sujeito e patrimônio simbólico.

Embora essenciais, aprendizagens nessa direção não parecem suficientemente desenvolvidas para o contato inicial com o sistema de conhecimento implicado na educação superior. No âmbito da relação com informações para realização dos trabalhos acadêmicos, o estudante $\mathrm{F}$ disse perceber que precisa entrar em contato com um universo de informações mais específico, evidenciando dificuldades para tanto:

Às vezes não sinto que estou adentrando tanto, mas que é um tema mais específico, que não vai jogar no Google e achar "de pronto" um texto que dá conta [do tema]. Uma coisa que eu achei diferente do ensino médio para a faculdade é que quando vou pesquisar no Google algum tema, em busca de um texto resumido em algum site [igual

\footnotetext{
${ }^{28}$ FREIRE, Paulo. Política e educação: ensaios. São Paulo: Cortez, 1993.
} 
encontrava no ensino médio] é muito raro encontrar, a maioria que eu encontro é só artigo acadêmico.

A fala revela que além de conteúdos intelectuais distintos, em outros meios e formatos o estudante se depara com um contexto que requer o domínio de novas formas de pesquisar informações, de novos métodos. Se anteriormente o estudante buscava uma síntese sobre um tema em buscadores online como o Google e era atendido de modo que considerava satisfatório, agora para obter resultados compatíveis com exigências na graduação, suas buscas demandam ampliação para outros circuitos assim como o emprego de estratégias que a princípio ignora. Nesse contexto, muitos irão entrar em contato pela primeira vez com informações constituídas e apresentadas em perspectiva diversa da qual estavam familiarizados na educação básica. Portanto, irão se deparar com contornos da ordem simbólica que lhes eram desconhecidos até então e que demandam determinados saberes à sua apropriação.

Por outro lado, a curiosidade epistemológica leva a considerar prováveis distinções no âmbito da mobilização para a pesquisa na educação básica e na superior. Em grande medida, na educação básica o estudante irá pesquisar a partir de temas estipulados pelo professor; sendo que na educação superior, porém, há certa liberdade para escolha dos temas de pesquisa que alguns nunca experimentaram. Assim, ao serem convidados a se interrogar sobre o que desejam (ou precisam) conhecer para elaborar os trabalhos das disciplinas, muitos irão experimentar uma situação totalmente nova que implica autonomia e curiosidade. Ou seja, "O que eu desejo ou considero que preciso conhecer face a isso?" é questionamento que, para muitos, não foi suficientemente desenvolvido no processo de formação, em grande parte, ainda pautado num modelo transmissivista de busca de respostas a questões postas e não de problematização e elaboração de perguntas. Por meio de práticas pautadas na curiosidade epistemológica, em que o sujeito interroga o mundo e seus fenômenos com rigor e método, abrem-se caminhos à (re)elaboração da ordem simbólica pelos sujeitos.

O processo do conhecimento implica, portanto, um sujeito desejante, que se mobiliza a partir das interações com o meio sígnico, construindo sua singularidade a partir de interesses que lhe são próprios. Há, todavia, situações e processos que impõem dificuldades ao reconhecimento e expressão do desejo de conhecer, indicando que, face a alguns quadros, são demandadas mediações voltadas à construção da percepção, pelo próprio sujeito, de seu desejo e necessidade de conhecimento. 
A perspectiva de conhecimento como construção de sujeitos desejantes e singulares implica dialogia como categoria operatória ao desenvolvimento de bibliotecas em quaisquer níveis de escolaridade, porque se trata de condição ao acolhimento da curiosidade epistemológica. É imperativo que a biblioteca universitária pressuponha um sujeito de palavra que dialoga com o patrimônio infodocumental, perscrutando-o, buscando apropriar-se dele, produzindo significados a partir de métodos rigorosos. A questão extrapola, evidentemente, a esfera das bibliotecas para alcançar a esfera da educação como um todo. Assim, o tema problematiza a maneira pela qual a educação superior e seus dispositivos comunicam a ordem simbólica aos estudantes: se convidam à assimilação do que está posto ou ao diálogo e ressignificação desse universo; questão que implica diretamente os sistemas de mediação existentes nesse circuito.

O termo epistemológico somado à curiosidade indica, portanto, a importância de modelos epistêmicos que coloquem o sujeito em relação com a pesquisa como constitutiva do processo do conhecimento, e também com os meios que viabilizem apropriar-se de métodos de formação científica e produção de conhecimento. Instrumentalizar o estudante desconsiderando sua dimensão simbólica, de alguém que interage com o mundo e o interroga a partir de seus desejos de conhecer, é desprezar o valioso princípio que tem por base a mobilização subjetiva como impulso aos atos de conhecimento. Sem considerar a esfera de significados do indivíduo, estará em causa prioritariamente a reprodução do patrimônio cultural e não sua (re)elaboração. Nesses termos, defender a pesquisa como prática de formação científica, forjada no desenvolvimento da autonomia, do rigor, da curiosidade epistemológica e da consciência crítica é alterar drasticamente sua perspectiva enquanto fórmula para se chegar a uma resposta a questões postas por outros.

Entretanto, a pesquisa é prática estranha a muitos estudantes, conforme indicativos coletados na bibliografia (ADACHI, 2017; BELLETATI, 2011; COULON, 2008), e nas atividades empíricas desta investigação. Por exemplo, de acordo com a Estudante G, seu interesse em participar das práticas propostas se deu pois "eu queria aprender sobre esse processo de pesquisar, porque eu acho que falta pra mim isso, eu não tenho uma base." A fala indica que embora houvesse desejos de aprender, além do acesso ao repertório disponibilizado pela biblioteca, por si só esses elementos eram insuficientes, na percepção da estudante, para que se relacionasse com o patrimônio infodocumental de forma consistente. 
O seu relato soma-se àqueles de estudantes que demonstram certo estranhamento em relação à biblioteca universitária, indicando uma experiência de nova ordem, mesmo para os que tiveram contato com bibliotecas em período de ensino anterior. De acordo com a Estudante D, "para mim essa biblioteca [da ECA-USP] foi uma experiência bem diferente". Enquanto a Estudante B, afirmou "eu acho que por mais que você já teve contato com outras bibliotecas, aqui é um espaço novo, meio que te intimida a se aproximar, a tentar entender como funcionam as coisas".

Os relatos evidenciam que para muitos o simples fato de ingressar numa biblioteca para tomar emprestado um livro não é um ato banal como ir a um supermercado comprar pão. Ingressar na biblioteca é adentrar num dispositivo que representa essa nova cultura, geradora de uma nova experiência para os estudantes. A sinalização do sentimento de intimidação experimentado em relação à biblioteca, indica uma possível barreira que se coloca entre estudante e essa estrutura que sintetiza uma determinada ordem simbólica e que, a depender das mediações que opera, poderá ser ultrapassada ou reforçada.

A abordagem da pesquisa como caminho essencial à elaboração rigorosa de questões face ao mundo e seus fenômenos, associada ao princípio da curiosidade epistemológica, sinaliza para a relevância do desenvolvimento de uma dimensão pedagógica da biblioteca universitária, aspecto que coloca em evidência a importância do diálogo, traduzido em dinâmicas de interação com a sala de aula. Sob esse enfoque, é possível considerar possibilidades de aproximação entre desejo de conhecer dos sujeitos e patrimônio infodocumental, a partir de processos dinâmicos da sala de aula em interrelações com a biblioteca universitária e práticas que lhe são próprias. Esse jogo contribuiria para o desenvolvimento da curiosidade epistemológica, por meio do encontro entre desejo de conhecer e rigor metódico.

\subsection{4 (Re)elaborar-se como leitor e como autor}

Os variados elementos que compõem o mundo, em suas dimensões material e imaterial, como o ecossistema, as diferentes espécies, os objetos, os signos, os valores, os ordenamentos sociais e culturais, etc. convidam o indivíduo a constituir-se enquanto sujeito a partir das relações que aí estabelece. Seja elaborando ou interrogando esses elementos, é nessa esfera relacional que o sujeito se constitui. Quando um físico 
interroga as partículas atômicas ou um estudante indaga sobre um conceito discutido em aula, ou ainda, um filósofo reflete acerca do conceito de verdade e um jovem questiona as instituições que conformam a sociedade desigual da qual faz parte, estão em interações inscritas no âmbito do sujeito (BECKER, 1999). Constituir-se enquanto tal, pressupõe ultrapassar a assimilação de repertórios e ingressar em dinâmicas de relações tendo em vista a apropriação simbólica.

A relação com o domínio da palavra escrita, em perspectiva crítica e afirmativa, constitui o processo de ser sujeito de um mundo em que as nomeações - as palavras, a linguagem - delineiam nosso pensamento e compõem contornos da simbolosfera. A palavra escrita, que rompe com tempo e espaço, é criadora de vínculos em nossa espécie, fundamental à partilha simbólica. Pensamos a partir delas e pensar, além de raciocinar, argumentar e calcular é, sobretudo, dar sentido àquilo que somos e àquilo que nos acontece, pois o modo como nos (re)elaboramos e agimos diante de nós, dos outros e do mundo vincula-se às palavras (LARROSA, 2015). A relação com a linguagem - e com a palavra escrita em específico - não corresponde apenas à relação com um conteúdo intelectual que se tem diante de si, mais que isso, é relação consigo, produtora de sentidos. Ser sujeito de palavra, implica alguém que constrói sentido, que se alimenta por meio de práticas culturais, de leitura e escrita, criadas como forma de participação na ordem simbólica.

Como vimos no capítulo 3, exames como o PISA, que avaliam conhecimentos e habilidades de estudantes brasileiros de 15 anos de idade no domínio da leitura, evidenciam que a elaboração do estudante enquanto leitor, não é alcançada de modo satisfatório em nosso sistema educacional (INEP/MEC, 2019b). Para muitos jovens, a relação com o texto se dá a partir de perguntas estabelecidas pelo professor, tendo em vista descobrir as ideias que o texto expressa. Essa relação deficiente que se estabelece com o sistema de signos, verbais ou icônicos (tabelas, imagens, gráficos, números, etc.), via de regra acompanha o sujeito quando do seu ingresso na educação superior, impactando nas relações que estabelece com a informação e o conhecimento, e reforçando um quadro de frágeis vínculos com o patrimônio simbólico. As dificuldades se acentuam nos extratos socioeconomicamente desfavorecidos da sociedade, que terão maiores dificuldades em se relacionar com o conhecimento acadêmico, mas não atingem somente esses segmentos.

Às dificuldades de relação com a palavra escrita somam-se àquelas implicadas na escolha do que ler. A Estudante A argumentou que "uma coisa é você ter esse monte 
de livro aqui na biblioteca para você consultar, outra coisa é você saber por onde começar. E muitas vezes eu acho que a gente não sabe por onde começar".

Em pesquisa sobre autodidatismo, realizada com estudantes universitários oriundos de classes socioeconomicamente desfavorecidas no contexto francês, Poliak (1993) expôs que muitos indicavam reconhecer a importância da leitura como condição para transformações em suas vidas. Entretanto, além da necessidade do desenvolvimento de certas formas de leitura para a compreensão do texto e produção de seu sentido, apontavam a dificuldade em escolher o que ler. Conforme um entrevistado indicou,

[...] me faltava coisas, eu não podia mais avançar (...). Num certo momento, eu falei: "Te falta ferramentas de análise, ferramentas para compreender bem certas coisas." Por exemplo, em sociologia, ou em filosofia, ou em psicologia por mais que você leia, eu acredito que você tem necessidade de certas pessoas que te expliquem certas coisas para que num certo momento você possa dominar o que você (lê...). É por causa disso que eu em inscrevi em Saint-Denis, para que alguém me forneça os meios de dominar melhor o que eu leio de um modo selvagem e para ter ferramentas para compreender direito o que eu leio, ferramentas de reflexão (POLIAK, 1993, não paginado, tradução nossa).

Para Poliak (1993), a pesquisa indicou que muitos estudantes encaravam a educação superior como possível instância de mediações que possibilitasse sua reelaboração como leitores. O autor indica que "dominar bem", "compreender a fundo", "classificar" e "selecionar" configuram expectativas expressas por alguns sujeitos que ingressaram na universidade.

De fato, o sujeito que lê um texto de ficção para fruição relaciona-se com ele de modo diverso daquele esperado para uma interação crítica com o texto acadêmico. São atos de ler que demandam posturas diversas, dada a distinção dos objetos que se tem diante de si. Ser um ávido leitor de obras literárias, de ficção, não corresponde à capacidade de leitura de textos acadêmicos, diretamente implicada no desenvolvimento do pensamento científico e crítico.

Nessa direção, Poliak (1993), indica que alguns estudantes procuram na educação superior um caminho para por fim, ou, ao menos minimizar, a desordem do pensamento e dos saberes. É como se procurassem na graduação bússolas cognitivas e sensíveis para se relacionarem com o patrimônio cultural. 
Em face disso, a educação superior demanda instâncias de mediação capazes de articular processos, práticas e produtos que favoreçam a relação do estudante com o universo simbólico, compreendendo justamente o domínio da leitura, ato produtor de sentidos. De um lado, há a questão das formas de ler, de outro, a necessidade de parâmetros para selecionar o que ler. Posto que as práticas de leitura são definidoras das relações dos estudantes com a ordem simbólica, da qual a biblioteca constitui categoria privilegiada, a problemática da leitura também concerne a ela.

Diante das afirmações, não está em causa problematizar a constituição de caminhos prontos a serem seguidos, de guias de leitura. A questão, de um lado, expõe a insuficiência de elementos para que os sujeitos, por si só, adentrem em relações afirmativas com a ordem simbólica. De outro, indica a importância de mediações que atuem nessa esfera, a partir do pressuposto de que o estudante é alguém que, ao se relacionar afirmativamente com o patrimônio cultural, constrói sua autonomia intelectual.

Nesse âmbito, a biblioteca universitária dispõe de elementos para atuar junto à esfera da produção de sentido e da constituição de parâmetros para seleção de repertórios informacionais, questão que, no tempo presente, marcado por enxurradas informacionais, mostra-se fundamental. Essas questões confirmam posições que entendem a lógica da difusão de informações como reforço aos hiatos entre sociedade e patrimônio simbólico, evidenciando que o modelo da mediação cultural na biblioteca universitária afeta a educação superior, no que tange à produção de sentidos e ao desenvolvimento de formas de ler.

A leitura modifica o objeto, portanto, o sistema de signos verbais ou icônicos configura formas que esperam do leitor o seu sentido. Nesses termos, o texto é também construção do leitor que, no ato de ler, não ocupa o lugar do autor tampouco um lugar de autor. O leitor é alguém que se relaciona com o texto, buscando construir - e não descobrir - a sua ideia central. (CERTEAU, 2003; KOPCKE FILHO, 1997). Problematizar a (re)elaboração do estudante como leitor a partir de sua relação com a cultura científico-acadêmica é condição essencial para que ele ingresse em interações com o conhecimento acadêmico, indispensáveis para se (re)elabore como autor, produtor de significados.

A leitura acadêmica demanda do sujeito a capacidade de compreender as operações da qual o texto é resultado e os conceitos inscritos no sistema de conhecimento apresentado em palavras. Implica relação com os significados que as 
palavras carregam, a apreensão do conhecimento vivo e não a busca por apreender esquemas verbais vazios (VIGOTSKY, 2001). O ato de ler é momento de encontro com significados que se conhece e também com aqueles ainda desconhecidos. O essencial é que o estudante pratique a leitura como atividade que não se baseia somente naquilo que aparece no texto, mas sim como ação que envolve buscar informações e construir significados para além do escrito no texto (KOPCKE FILHO, 1997).

O relato da Estudante A vai ao encontro da questão quando diz que "eu tinha muita mania de passar direto no texto para o que eu entendia, o que eu não entendia eu deixava quieto, mas hoje estou parando, eu consigo hoje em dia parar no meio do texto e ir pesquisar para entender o que está escrito". De um lado, a fala evidencia o não domínio da leitura como atividade que demanda a compreensão de um sistema de significados e, para tanto, implica estratégias específicas. Por outro, revela que a estudante buscou (re)elaborar-se como leitora, reconhecendo a necessidade de incluir outros elementos que lhe permitissem uma relação efetiva com o texto acadêmico, mesmo que o processo implique desvios, contornos, retrocessos aspectos que, de resto, escapam à leitura abrangente imposta pela velocidade dos fluxos informacionais. Entretanto, a transformação que relatou experimentar, após sua participação nas atividades empíricas deste estudo, não irá necessariamente levar a um caminho consistente de (re)elaboração de si como leitora numa cultura científico-acadêmica que não disponha de dispositivos que, na prática, acolham sua percepção de necessidade de transformação.

Muitos estudantes universitários consideram a leitura constante de textos acadêmicos essencial, relatando a necessidade de desenvolver uma relação autônoma com a produção científica escrita, por meio de práticas de leitura consistentes, conforme evidenciou pesquisa de Gomes (2008). Contudo, mesmo somado a essa percepção, o ingresso na educação superior não garante transformações espontâneas, as quais dependem de dispositivos e ações efetivas nessa direção, inseridas no próprio processo de formação.

Para Kopcke Filho (1997), são necessárias ações específicas dirigidas aos estudantes para que aprendam a ser leitores - "aprendam a ler" -, para que identifiquem quando sua compreensão está prejudicada e que estratégias adotar. Flippo e Caverly (1991 apud ${ }^{29}$ KOPCKE FILHO, 1997), a partir de estudos comparativos sobre a leitura,

\footnotetext{
${ }^{29}$ FLIPPO, R. F.; CAVERLY, D. C. (Org.) Teaching reading \& study strategies at the college level. Newark, Delaware: IRA, 1991.
} 
relatam que leitores menos hábeis, independentemente da idade, apesar de reconhecerem suas deficiências de compreensão, não sabem como saná-las. Além disso, constataram que alguns leitores acreditam ter compreendido a leitura, quando isso de fato não ocorreu.

Na pesquisa de Adachi (2017) sobressaíram relatos de estudantes sobre possuir conhecimentos, entendidos como conteúdos intelectuais, sem, no entanto, saber conectá-los. Segundo um entrevistado que se evadiu da graduação, "era muita informação, meio que tudo desconexo" (ADACHI, 2017, p. 255), fala que evidencia a dificuldade do sujeito em produzir o sentido daquilo que recebe, de estabelecer relações e conexões por si mesmo capazes de projetá-lo em direção a novas e efetivas vinculações com o patrimônio simbólico, fundamental à sua formação universitária. Práticas que tomem a leitura como construção de sentido e não como sobreposição de camadas de conteúdo na mente do estudante são essenciais à ampliação de sua esfera de presença no mundo e participação na linguagem escrita como um autor.

São demandados, contudo, referenciais para que o sujeito atribua sentido às informações, pois a leitura é ato de relação com signos produzidos por sujeitos em contexto. Portanto, não é simples técnica de decodificação que, quando bem executada, irá alçar o sujeito à condição de produtor de conhecimentos, assim, adentrar no mundo das ideias, comunicando-se por meio da leitura, demanda ações que extrapolem esse entendimento. De outro lado, a leitura em profundidade é construção do sujeito e exige que o mesmo exerça seu potencial de simbolizar, o que demanda paciência, tempo, reflexão.

Nesse sentido, a experiência particular do sujeito com os signos e a experiência da relação com outros leitores e contextos fazem da biblioteca universitária um locus essencial à formação do leitor. No entanto, conceber a biblioteca universitária sob a ótica da facilitação da oferta simbólica, viabilizando o acesso a respostas prontas, é abordagem que se interpõe a uma lógica que entende o patrimônio cultural como manancial à espera de leitores interessados em reconstruir significados, descobrir e tramar novas conexões, criar sentidos singulares e únicos. A leitura que toma o texto como sentido encerrado em si mesmo traz reflexos às relações com o patrimônio infodocumental das bibliotecas universitárias. Superar a incompreensão do texto como o ponto de uma trama, em alguma medida, ajudará o estudante em seus percursos pelas teias do conhecimento, aspecto sobre o qual a apropriação da biblioteca universitária tem muito a contribuir. 
A (re)elaboração da prática da leitura acadêmica tem reflexos sobre a formação do estudante-autor, alguém que comunica algo a partir de um desejo de dizer, dimensão que constitui grande dificuldade para muitos.

A escrita, por sua vez, não configura tradução da linguagem falada para signos escritos, e apreender a linguagem escrita não corresponde à apreensão da técnica da escrita. Para Vigotsky (2001), a escrita requer o desenvolvimento de um alto grau de abstração, é uma linguagem de pensamento, de representação, desprovida do aspecto sonoro da linguagem falada. Assim, ter vocabulário e ser capaz de entabular conversas sobre um assunto não corresponde à capacidade de escrita, que demanda operações de outra ordem. A própria situação da linguagem falada estabelece para o sujeito um caminho de possibilidades para desenvolvê-la. A pergunta seguida pela resposta, a incompreensão pela explicação, dentre outras possibilidades determinam o desenvolvimento da ideia expressa na linguagem falada, a qual é regulada por situações dinâmicas. Já na linguagem escrita, o sujeito precisa representar uma situação em seu pensamento, sendo requerido que elabore "um tratamento mais independente, mais arbitrário e mais livre dessa situação.” (VIGOTSKY, 2001, p. 315).

Conforme Belletati (2011), tanto a escrita acadêmica como a utilização de normas técnicas para redação inscrevem-se no rol das dificuldades apontadas por estudantes que abandonaram o curso de graduação. A constatação é a evidência de uma dificuldade não superada nesse domínio, em que a escrita obedece a determinadas regras discursivas, implicando introduzir um problema, desenvolver uma ideia, demonstrar, citar corretamente, elaborar referências. Certas regras e saberes escapam a muitos estudantes, inviabilizando sua participação nessa ordem simbólica enquanto autores/sujeitos em busca de expressão.

A estudante G, ao participar das atividades empíricas deste estudo e entrar em contato com a abordagem da escrita como prática a ser desenvolvida ao longo do processo formativo, afirmou que

Tranquilizou bastante [...] e tira um pouco dessa pressão de que você tem que escrever o texto perfeito e que tem que ser alguma coisa muito genial, porque o vídeo ${ }^{30}$ que você mostrou, ele fala que ninguém começou desse jeito, ninguém começou com texto bonito,

${ }^{30}$ A estudante refere-se ao seguinte recurso: FERRAZ, Marcus Sacrini. Introdução à escrita acadêmica (Aula 10, parte 2). Canal da USP. Disponível em: https://www.youtube.com/watch?v=fYoGkpYhcVE . Acesso em: 08 jul. 2020. 
não bonito, mas genial, entre aspas, então foi bem legal ver que tudo isso faz parte de um processo e que você vai evoluindo aos poucos.

É grande o número de estudantes que não compreende a elaboração do texto como um processo que implica a elaboração de diversos rascunhos antes de se chegar à obra final (BECKER, 2015). Ao entrar em contato com textos acadêmicos, os estudantes podem acabar tomando estes como modelo, focando mais na forma do que no conteúdo. Há o risco de que, em seus textos acadêmicos, se preocupem em empregar palavras belas em detrimento do conteúdo, de comunicar uma ideia que expressa um ponto de vista particular para potenciais interlocutores. Assim, há o risco de que a construção do significado do texto escrito pelo estudante fique em segundo plano, o que o distancia de sua participação no processo do conhecimento.

A falta de clareza do conhecimento como um processo está implicada nesse modo de relação do estudante universitário com a linguagem escrita. Muitos estudantes não constroem a imagem de si como potenciais autores, alguém com ideias para comunicar em linguagem escrita, dada a precariedade das práticas de escrita em seu percurso educacional (BECKER, 2015).

Não construir a imagem de si como um autor no universo acadêmico é inviabilizar possibilidades de se constituir como sujeito que (re)elabora o patrimônio cultural desse circuito. Há que se observar que a imagem que o estudante tem de si se dá a partir de dinâmicas com o meio. Nesse aspecto, a relação com a biblioteca universitária, presencial, com sua variabilidade de repertórios, seus modos de ordenação, suas práticas oportunizam a redefinição das representações que o estudante tem de si mesmo, aspecto essencial à articulação de três eixos dinâmicos da ordem do conhecimento: a educação superior, o estudante e a linguagem escrita.

O sociólogo estadunidense Howard Becker (2015), ao ministrar cursos de escrita para pós-graduandos e contar que normalmente reescreve de oito a dez vezes um manuscrito antes de sua publicação e que, antes disso, também o submete à leitura por amigos, afirma que a fala gera surpresa, pois muitos estudantes acreditam que pessoas como ele, tido como um "bom escritor", já conseguem redigir tudo adequadamente na primeira vez. Para o autor, essa incompreensão ainda prevalente na pós-graduação guarda relações com a prática da escrita na educação anterior do indivíduo, pois, na educação superior, de modo geral, os estudantes redigem suas monografias já como uma versão final, elaborando cópias de trechos de outros textos, não desenvolvendo suas próprias ideias. Na graduação muitos estudantes montam mentalmente a estrutura da 
monografia, às vezes elaboram um esboço geral e, então, escrevem tudo de uma única vez, prática que acaba sendo consolidada num contexto em que têm que entregar diversos trabalhos ao fim do semestre. Assim, a prática de reescrever, de elaborar rascunhos como algo constitutivo do processo de comunicação textual não é desenvolvida a contento, tampouco compreendida pelos estudantes. E, face a essas dificuldades, o estudante pode sentir-se incapaz de se comunicar nessa modalidade de linguagem.

A questão vai ao encontro da pesquisa de Adachi (2017), que evidencia que a elaboração da monografia de conclusão de curso configura momento de muita provação para estudantes de graduação, sendo que alguns chegam mesmo a desistir do curso, não conseguindo elaborá-la.

Para além do processo propriamente, conforme observado por Larrosa (2015), aquilo que fazemos com as palavras refere-se a como damos sentido ao que somos e aquilo que nos acontece, projetando-nos no mundo. Portanto, as relações com a linguagem escrita - seja enquanto leitor seja enquanto autor - são definidoras de nossas relações com o mundo e seus fenômenos. Segundo Paul Otlet (L’HOMME, 2002), escrever era a forma para colocar em ordem o seu pensamento, organizar as ideias. Daí a importância da escrita refletida - que desafia o pensamento e coloca em desafio outros pensamentos, mobilizando a memória cultural - contrapor-se à escrita rápida, superficial, mecânica, unicamente reativa a demandas imediatistas.

Práticas nessa direção são essenciais a uma perspectiva democrática na educação superior e nos processos do conhecimento acadêmico. Nesse sentido, vale lembrar das palavras de Manguel (ALBERTO..., 2015), quando considera que o espaço da palavra escrita cria espaços de pensamento sem fronteiras.

Muito embora o acesso à educação superior tenha sido bastante ampliado em nosso país, muitos estudantes permanecem às margens desse espaço da palavra escrita, por não disporem de repertórios e saberes indispensáveis à compreensão dessa ordem simbólica. Transformações na fratura entre sociedade e conhecimento implicariam rever hiatos entre a biblioteca e sala de aula na cultura científico-acadêmica, inserindo a biblioteca em práticas pedagógicas de produção de sentido pelo estudante. 


\section{3 (RE)ELABORAR ESTRUTURAS DE ACOLHIMENTO E SOCIALIZAÇÃO: O LUGAR DA BIBLIOTECA UNIVERSITÁRIA NA EDUCAÇÃO SUPERIOR}

Como discutido anteriormente, o conhecimento não é compreendido, por muitos estudantes, como um processo. Do mesmo modo, parcela considerável dos estudantes não dispõe de saberes e fazeres para se relacionar com o patrimônio infodocumental de forma crítica e criativa, seja por falta de experiência com os ambientes culturais, seja pelas lacunas estruturantes da educação básica. Em decorrência, as fragilidades se manifestam não somente na forma objetiva de dificuldades concretas à produção de conhecimento, mas também na dimensão simbólica, refletindo na imagem de si como alguém que não foi destinado a participar e contribuir para a constituição da ordem simbólica de seu tempo, alguém que não pode ou não tem direito à memória cultural.

Até este ponto da tese, as discussões trazem indícios de duas faces da questão, mutuamente relacionadas. De um lado, há uma ordem simbólica construída a partir de dinâmicas históricas e sociais, produtoras de hierarquizações e apagamentos na simbolosfera e que implicam em movimentos de homogeneização no circuito do conhecimento. Assim, para participar do processo do conhecimento acadêmico, é preciso curvar-se a certas regras, valores e princípios, na medida em que a cultura científico-acadêmica é forjada a partir desses elementos e não a partir da consideração de um sujeito de palavra em inter-relações com o mundo, com os outros e a simbolosfera. De outro lado, a discussão revela a problemática da participação do sujeito no processo de diálogo com o patrimônio infodocumental e de produção de conhecimento em meio à falta de repertórios e saberes, não considerados como objetos essenciais a serem tratados pelas esferas da educação superior. Como vimos, a curiosidade epistemológica, o rigor, a autonomia intelectual, a metacognição para a leitura, o elaborar-se como um autor, dentre outros elementos, são condições essenciais às negociações do sujeito com o patrimônio infodocumental. É nessa problemática que se encontra a biblioteca universitária. Na medida em que seu papel for encarado em perspectiva apenas procedimental - de fornecimento de informações e treinamento para acesso competente a elas -, deixar-se-á de lado sua dimensão educativa, prevalecendo um modelo comunicacional linear de envio de mensagens a um receptor, modelo alheio à esfera das significações e à participação daqueles a quem chamamos sujeitos de palavra. 
A atividade empírica trouxe indicativos de que ações promovidas a partir da biblioteca, buscando a interação dos estudantes com o patrimônio infodocumental, têm potencial para reelaboração das percepções que eles têm do conhecimento acadêmico e de si em relação ao meio, aspecto essencial ao desenvolvimento de uma cultura científica no país. Conforme relatou a Estudante A, ao avaliar sua participação na pesquisa empírica,

[...] para mim isso daqui [as atividades desenvolvidas na pesquisa empírica junto aos estudantes] foi muito importante, eu acho que se eu não tivesse isso eu, sei lá, provavelmente teria desistido depois, porque você leva um choque, no primeiro semestre é muita coisa que tem que fazer, tanta coisa que você nunca viu na sua vida. Eu lembro que nas primeiras semanas eu pensava... como que vou entregar tudo isso, como que vou fazer tudo isso.

Promover o acolhimento do estudante na cultura científico-acadêmica é algo essencial à sua participação no processo do conhecimento. Proporcionar aos estudantes meios de ingressar no processo de construção de significados, a partir de relações com informação científica e conhecimento acadêmico, irá implicar estruturas de acolhimento e socialização que articulem tanto dimensões materiais como simbólicas, que introduzam o sujeito nesse novo meio, conferindo-lhe condições de possibilidade para que dele pertença e participe (JESUS, 2018).

Nesse contexto, a Estudante $C$, que já havia cursado uma primeira graduação na USP, indicou seu desejo em participar das atividades empíricas, pois considerou que, mesmo terminando a graduação, esteve à margem do processo do conhecimento:

\footnotetext{
A maioria [dos estudantes] se sente deixado de lado...e eu acho que eu preciso disso, eu senti falta desse retorno, de acompanhar o processo da pesquisa em si...então eu saí de lá [da primeira graduação em Letras na Faculdade de Filosofia, Letras e Ciências Humanas/USP] insegura e como se estivesse faltando alguma coisa mesmo.
}

Se existe todo um movimento que visa introduzir o estudante em diferentes práticas com o intuito de incluí-lo na comunidade acadêmica, observa-se, contudo, que na esfera da formação científica e produção de conhecimento o processo é complexo e demanda tempo porque implica diferentes elementos da ordem simbólica. Reelaborar estruturas da cultura científico-acadêmica, dentre elas em especial a biblioteca universitária, constitui caminho para transformações da referida ordem simbólica. Conforme o Estudante F, “eu achei que [com] esses encontros [...] eu comecei a ver que 
eu pertenço mais ou menos a esse processo do conhecimento que a biblioteca fornece pra gente e isso foi bom porque dá mais vontade de procurar as coisas".

Não está em causa argumentar que a biblioteca tem potencial de transformação da educação superior e da ordem simbólica isoladamente. Uma experiência breve como a empreendida nesta tese não sustenta afirmações nesse sentido, tampouco se pode desconsiderar o paradigma que rege as lógicas do sistema educacional brasileiro, cuja abrangência extravasa a biblioteca universitária e a educação superior. Mas não podemos deixar de apontar que a experiência evidencia um problema na esfera das relações do estudante com o conhecimento e, também, traz indícios de possibilidades de transformações nesse domínio. Se o modelo de biblioteca universitária - articulado tanto a um modelo de educação superior como a um modelo de sociedade - for posto em questão, abre-se espaço à quebra de paradigmas e a possibilidades de construção de novos paradigmas que considerem exigências científico-acadêmicas contemporâneas.

É preciso problematizar em que medida o acesso ao patrimônio infodocumental inscreve a biblioteca universitária em dinâmicas propulsoras da democracia, da interculturalidade, do direito de participação no conhecimento acadêmico. Submeter a biblioteca aos modelos comunicacionais impostos pelas lógicas que regem a educação de massas é seguir por trilha que desconsidera as fraturas da ordem sociocultural atual. Ordem que inscreve os sujeitos em dinâmicas de consumo simbólico que pouco contribuem para compreensões do mundo que superem os referenciais de senso comum. Desconsiderar a significação e as formas de relação com o conhecimento é uma maneira de perpetuar uma ordem simbólica fixa e não aberta a transformações, na medida em que não são criados modos para que diferentes e desiguais entrem em negociações culturais com ela.

Quando a instituição de ensino dispõe de uma estrutura de acolhimento do estudante como membro afirmativo da cultura científico-acadêmica, assumindo que ele tem voz, propiciando o desenvolvimento de novas formas de se relacionar com o binômio informação e conhecimento, ela abre caminhos à manifestação do indeterminado, àquilo que advém do encontro afirmativo de um sujeito singular com a simbolosfera. Estudantes ingressantes que participaram da pesquisa empírica afirmam ter vivenciado novos modos de relação com a informação e o conhecimento, sinalizando para a importância de contextos especificamente constituídos para a relação com o patrimônio infodocumental. 
Conforme percepção da Estudante D, participar das atividades empíricas desta tese

Foi uma forma de realmente viver isso, não só de organizar o pensamento, mas também do porquê você precisa organizar, sabe? Também da importância de você organizar... existe um significado, não é uma coisa meramente técnica, não é só para você gerar um produto, é um processo, é uma coisa muito mais abstrata, subjetiva... é complexo... mudou a minha relação com a biblioteca e com o conhecimento.

Nessa linha, Gomes (2006) indica que atividades como leitura, pesquisa e debate demandam ambientes externos à sala de aula, promovendo-as como constitutivas do próprio processo de formação superior. Para tanto, estão em causa estruturas que acolham o sujeito, considerando-o como um ser de significados que, em diálogo com os significados do meio, reelabora a experiência de si como ser-sujeito - e não objeto - da cultura científico-acadêmica. A biblioteca universitária, na medida em que extrapola os conteúdos intelectuais dos cursos de graduação, é uma esfera que, integrada a dinâmicas pedagógicas, mostrou-se promissora nessa direção.

Entretanto, Gomes (2008) destacou que os dispositivos da cultura científicoacadêmica, que atuam na esfera da relação dos estudantes com o par informação/conhecimento, não dispõem de uma meta comum interligando suas ações. A afirmação leva a salientar a importância de que esses dispositivos (bibliotecas, salas de aula, laboratórios, centros esportivos, museus, teatros, etc.) interroguem os pontos de vista que lançam sobre e entre si mesmos. Ou seja, sobre suas especificidades, domínios e complementaridades, tendo em vista sua função na construção da cultura científicoacadêmica e na relação que estabelecem com os estudantes em dinâmicas que guardam relação com a (re)elaboração do próprio mundo.

Acolher o estudante no sistema de conhecimento compreende a noção de socialização, ou seja, implica a aprendizagem de atitudes e comportamentos realizada em contextos de interação com informação científica, conhecimento acadêmico e demais sujeitos que integram o meio. Na socialização está em causa a interiorização de valores, normas e esquemas de ação, assim como o acesso a múltiplos sistemas de interação como interlocução e cooperação, que se referem ao sujeito de palavra (MALEWSKA-PEYRE; TAP, 1991; SARABIA, 2000). Portanto, a socialização é 
essencial à sobrevivência e ressignificação da própria cultura científico-acadêmica, na medida em que possibilita que se abra à apropriação pelos estudantes.

A cultura científico-acadêmica de fato acolhe os sujeitos quando os reconhece em sua existência enquanto seres com desejos e necessidades - tanto latentes como explícitas (JESUS, 2018) -, rejeitando assim as dinâmicas de aprendizado por meio de fórmulas prontas para se relacionar com o patrimônio infodocumental. O conhecimento não é autônomo nem universal, mas uma construção contextualizada que implica diferenças culturais e também políticas. Indicar a importância de que a cultura científico-acadêmica disponha de dispositivos de fato comprometidos com a relação estabelecida pelo tripé estudante/informação/conhecimento, implica que o estudante seja considerado em sua dimensão cultural, sujeito de significados que entra em diálogo com os significados da cultura científico-acadêmica, culminando em reelaborações mútuas evitando riscos de empobrecimento do próprio patrimônio cultural. Assim como a biodiversidade, a diversidade cultural é garantidora de condições de preservação e continuidade da espécie, que se distingue pela capacidade singular de simbolizar, de criar significados a partir de outros significados.

Se ao adentrar na cultura científico-acadêmica muitos estudantes se sentem como a personagem Alice ao cair na toca do coelho, não sabendo mais quem são, dadas as diversas novas experiências que os convidam a se reelaborarem em suas relações com o mundo e consigo mesmos, entendemos que cabe aos organismos institucionais e seus dispositivos assumir, por assim dizer, sua parcela Alice, interrogando-se face ao presente e ao futuro. Embora a paisagem em que a IES se insere possa ser a mesma - o mesmo país, cidade, bairro -, os tempos e seus públicos são outros, exigindo indagações acerca de seu próprio papel e metodologias de atuar na sociedade, o que inclui especialmente, dada sua natureza, as relações entre sua comunidade e o patrimônio infodocumental. Nessa esfera, inscreve-se a biblioteca universitária, desafiada a ultrapassar patamares de oferta de recursos informacionais para atingir configurações intrinsecamente educativas, discutindo o lugar que lhe cabe na reversão da ordem fragmentada de ensino que desfavorece a participação dos não-iniciados na cultura científica; problema que, na contemporaneidade, parece acometer grandes contingentes das novas gerações.

Uma biblioteca universitária dialógica, tomada como um fórum de interações simbólicas com vistas à produção de sentidos, será pautada pelo reconhecimento de sujeitos e seus repertórios, em relações afirmativas com o patrimônio cultural em causa 
na educação superior. Nesse sentido, a dialogia configura categoria a uma biblioteca universitária pautada no acolhimento e socialização dos sujeitos de conhecimento, pressupondo reciprocidade e interdisciplinaridade de trocas simbólicas, valorizando a relação do Eu cultural com o Outro cultural, considerando o lugar do outro sem, entretanto, abdicar de sua especificidade (BUBER, 1982; PERROTTI, 2016; ZITKOSKI, 2008).

Tal perspectiva envolve a concepção de biblioteca universitária como um todo, pensada a partir de regras próprias, cujas lógicas dizem respeito à natureza da matéria com a qual lida e ao seu público. E coloca em causa o desafio do desenvolvimento de uma abordagem educativa da biblioteca universitária enquanto instância ocupada com processos de construção de saberes, flexível, aberta ao diálogo e ao compartilhamento do patrimônio cultural entre pessoas distintas - membros estáveis da comunidade acadêmica e novas gerações de estudantes -, mas inscritas numa mesma coletividade. 


\title{
5 OS SENTIDOS DA BIBLIOTECA UNIVERSITÁRIA
}

\begin{abstract}
Esta ordem não é tão firme como aparenta; nenhum objeto, nenhum eu, nenhuma forma, nenhum princípio é seguro; tudo sofre uma invisivel, porém incessante, transformação; no instável, o futuro tem mais possibilidades que no estável, e o presente nada mais é que uma hipótese ainda não superada. (MUSIL apud LARROSA, 2004, p. 33)
\end{abstract}

A biblioteca universitária é colocada em discussão nesse capítulo que se desenvolve a partir de dois eixos. Em um deles, apresentamos reflexões em torno da experiência empírica realizada neste estudo. No outro, realizamos a análise de discursos que trazem representações de biblioteca universitária no Brasil, por meio de textos publicados em anais dos eventos ENANCIB e SNBU.

Como já caracterizamos, a biblioteca universitária é um dispositivo de relações entre sujeitos de palavra e o patrimônio infodocumental, portanto de projeção do sujeito no mundo por meio de vinculações e diálogo com a memória cultural. A partir da análise dos discursos, consideramos que a biblioteca universitária é representada em meio a uma rede de sentidos que demanda rigorosa revisão teórica para que seja representada como dispositivo de inter-relações entre sujeitos, cultura e patrimônio infodocumental. Para tanto, o conceito de mediação cultural emerge como categoria articuladora dessas relações.

\section{1 (RE)PENSAR A BIBLIOTECA UNIVERSITÁRIA: INDÍCIOS DA EXPERIÊNCIA}

Face ao problema de pesquisa realizou-se atividade empírica ${ }^{31}$ a fim de contribuir para o adensamento de nossas discussões. Partimos do pressuposto de que possíveis dificuldades em termos de relação com o conhecimento acadêmico e a informação científica na educação superior não estão inscritas unicamente no estudante, mas sim nos próprios meios a partir dos quais a biblioteca e a universidade fomentam o conhecimento acadêmico.

\footnotetext{
${ }^{31}$ Esta seção traz reflexões sobre motivações e alguns achados da atividade empírica. Para informações descritivas, ver o item 1.1 Metodologia.
} 
Nesse sentido, assumimos que à discussão sobre biblioteca universitária no século XXI seria fundamental problematizar a relação do estudante universitário com o patrimônio infodocumental em causa na educação superior. Assim, as atividades empíricas, idealizadas em perspectiva dialógica, centraram-se no processo de relações do estudante ingressante com esse patrimônio implicado na educação superior, cujos contornos constitutivos escapam a muitos estudantes.

O ingresso na educação superior é momento marcante do processo de socialização do sujeito na cultura científico-acadêmica, pois configura o início do deslocamento do ser para um novo contexto que demanda a elaboração de novas formas de experiência de si. A questão é particularmente significativa na relação com o conhecimento na educação superior que, para muitos estudantes, se coloca de modo bastante diverso daquele experimentado na educação básica, demandando novos saberes, fazeres e atitudes. Foi nessa perspectiva que desenvolvemos as atividades empíricas com estudantes ingressantes, pois elas possibilitaram o contato com questões emergentes desse primeiro encontro do sujeito com a ordem simbólica constitutiva da educação superior. Com isso, buscamos abrir espaço ao surgimento de elementos que contribuiriam para incursões teóricas em torno da biblioteca universitária como dispositivo de socialização do sujeito na cultura científico-acadêmica. Para tanto, os conceitos de curiosidade epistemológica, consciência, rigor, criticidade e autonomia, tal qual abordados por Paulo Freire (STRECK; REDIN; ZITKOSKI, 2008), foram basilares às ações propostas.

As seis atividades, realizadas entre abril e junho de 2019, possibilitaram a observação da relação do estudante com a informação científica e o conhecimento acadêmico. Cabe frisar que o empírico não configurou busca por diagnósticos para prescrições. A experiência constituiu dimensão de valor ao buscar elementos de uma zona de interculturalidade - entre o científico e não científico - que está na base dos processos de apropriação de conhecimento e significação.

A ação desenvolvida com 12 participantes voluntários - de um total de 22 convidados a participar - é indicativa de que uma parcela de universitários sente necessidade de elaborar novos modos de relação com a informação e o conhecimento na educação superior. Se o interesse manifesto pelos estudantes que integraram a pesquisa nos leva a fazer tal afirmação, a não participação de outros estudantes também pode ser indício da ausência de necessidades e desejos nessa direção, ou ainda falta de tempo ou o não reconhecimento da questão. 


\section{a) Atividade 1: "O homem da cabeça de papelão" como recurso para refletir sobre a autonomia intelectual}

Nossa primeira atividade contou com 11 estudantes e, além de uma discussão sobre os encontros que teríamos, fizemos a leitura partilhada do conto "O homem da cabeça de papelão", de João do Rio ${ }^{32}$. A seguir apresentamos o resumo da obra e considerações sobre aquilo que nos mobilizou para escolhê-la como elemento do percurso empírico.

Resumo: Na obra somos apresentados a Antenor, personagem que vivia num país que era o "mais comum, o menos surpreendente em ideias e práticas" e no qual o povo “julgava-se, além de inteligente, possuidor de imenso bom senso.” Antenor era exceção malvista nesse país, pois agia em desacordo com a norma dos demais. Ele dizia a verdade, vestia-se, andava e se expressava de forma diferente. Mais que isso, o rapaz atrevia-se a pensar por conta própria. Diante dos infortúnios advindos da diferença, o jovem resolveu levar sua cabeça desarranjada para ser ajustada por um relojoeiro. Antenor ficou com uma cabeça de papelão, enquanto a sua estava no conserto. Passados dois meses de cabeça de papelão, o jovem tinha amigos, relações com pessoas influentes, aprendeu a mentir e a trapacear e, finalmente, parou de pensar por conta própria. Antenor agia como os outros, explorava e adulava. Foi eleito deputado! Assim, passaram-se anos até que se lembrou da cabeça deixada no relojoeiro e foi retirá-la. Chegando lá, o relojoeiro explicou que não consertou sua cabeça, pois ela é um aparelho sem igual, preciso e perfeito, jamais havia encontrado cabeça que regulasse tão bem quanto aquela, uma cabeça de sensibilidade e ideias. Entretanto, Antenor optou por não restituir sua cabeça escolhendo ficar com a de papelão, pois considerou que as cabeças devem ser reguladas "conforme o clima e a moral de cada terra". Para ele, "a verdade é a dos outros, que sempre julgaram [sua cabeça] desarranjada e não regulando bem". E assim, viveu Antenor como alguém que não conseguia ser nada com sua cabeça pensante e acabou tornando-se sujeito ilustre ao optar pela cabeça de papelão.

A atividade pretendeu mobilizar os participantes em discussões sobre o processo do conhecimento, que inclui querer e saber olhar para si mesmo, sem perder de vista a inserção num meio cultural mais amplo. O conto "O homem da cabeça de papelão" foi,

\footnotetext{
${ }^{32}$ Disponível em: https://novaescola.org.br/conteudo/3190/o-homem-de-cabeca-de-papelao. Acesso em: 24 out. 2020.
} 
assim, selecionado como recurso para leitura partilhada e mediada pela pesquisadora, tendo em vista consideração aos elementos implicados no capítulo 2 da tese, ou seja, a problemática das relações dos sujeitos com o binômio informação e conhecimento na contemporaneidade. Para Han (2017b), as relações com o universo simbólico são marcadas pelo apagamento das diferenças e fragmentação da atenção em meio ao volume de estímulos informacionais que marcam nossas vidas. No contexto das TIC, segundo ele, as interações se dão, sobretudo, a partir de representações do igual, o que afeta as possibilidades para a alteridade e o diálogo, que acabam à margem dos processos comunicacionais nesse circuito. A questão, em decorrência, sinalizou para a importância de abordarmos com os estudantes a autonomia intelectual como atitude que se desenvolve a partir de relações com a simbolosfera. Além de trazer à tona a importância de problematizarmos processos de hierarquização dos campos do conhecimento, fenômeno de natureza histórica com forte impacto sobre a ordem que valida determinados conhecimentos e seus respectivos portadores, conforme abordado por Boaventura de Sousa Santos (2009).

A partilha das impressões sobre o texto permitiu observar que as dinâmicas contemporâneas de relações com a informação e o conhecimento são problematizadas pelos estudantes em alguma medida. Muitos apontaram o consumo acrítico de informações nas bolhas das redes sociais como um problema de nosso tempo sem, entretanto, considerarem-se como integrantes desse meio. A partir do princípio de que interiorizamos o lado de fora, a pesquisadora convidou os estudantes a interrogarem suas relações com a informação e o conhecimento problematizando se, por vezes, vestem a cabeça de papelão. Nesse sentido, o processo mostrou que a cabeça de papelão pode estar em qualquer lugar: no senado, numa companhia de teatro, na administração de uma empresa, ocupando posições diversas na universidade. A questão foi posta para convidá-los a observar que a cultura científico-acadêmica não é imune às cabeças de papelão. Estar inserido no contexto acadêmico não corresponde necessariamente a ter ou desenvolver "uma cabeça de sensibilidade e ideias", como aquela do conto lido. Com isso, objetivou-se convidá-los a observarem suas relações com o par informação/conhecimento em diferentes circuitos, assim como evidenciar que elaborarse como sujeito autônomo intelectualmente demanda dinâmicas de inter-relações com a ordem simbólica, divergentes daquelas da constituição do sujeito de massas. O que demanda, por sua vez, dispositivos constituídos não apenas para fornecer mais 
informações, mas concebidos considerando entraves implícitos nos processos de autonomia e emancipação do pensamento em dada ordem simbólica.

Conforme relato do Estudante F,

\begin{abstract}
Achei muito interessante quando você mostrou esse texto porque achei um texto muito legal e que deu para refletir bastante, deu para usar ele bastante nos outros encontros. Na metade dos encontros às vezes falavam de 'ah tal coisa' e aí eu lembrava do texto. Durante o processo de pesquisa [para realização do trabalho final da disciplina], em vários momentos acabei lembrando desse texto.
\end{abstract}

Nesses termos, de um lado, a atividade evidenciou a autonomia intelectual como um princípio a ser considerado pelos estudantes, de outro, buscou mobilizá-los a observar que as instituições e suas práticas formam o pensamento. Assim, certas dificuldades que reconhecem em suas relações com a ordem simbólica não correspondem a uma suposta e preconceituosa incapacidade cognitiva inerente. Pelo contrário, foram forjadas a partir de determinado paradigma educativo-cultural ancorado em lógicas que, ao valorizar transmissão e reprodução do conhecimento, não incluem a construção do conhecimento como categoria central aos processos de formação cultural. Por sua vez, o próprio interesse dos estudantes em participar da pesquisa empírica e seu envolvimento nas atividades revelou o desejo de conhecer, de pensar autonomamente diante do reconhecimento da falta de ferramentas intelectuais para tanto.

As questões ressaltaram a importância de evidenciar que a IES e seus dispositivos têm implicações no desenvolvimento "de cabeças diversas daquelas de papelão". Se reconhecemos que a biblioteca é instituição que historicamente teve o papel de sistematizar e disponibilizar o patrimônio simbólico, cabe interrogarmos acerca de seu lugar na construção de esferas de intersecção cultural. Ou seja, em que medida atua no processo de formação de um pensamento acadêmico crítico e criador que compreenda os contextos dos diversos participantes do circuito universitário?

\title{
b) Atividade 2: a curiosidade epistemológica a partir do conto "There are more
} things"

A segunda atividade contou com a presença de 12 estudantes e problematizou o processo de pesquisa tendo a curiosidade epistemológica como ponto de partida. Além de apontamentos em torno do processo de pesquisa considerando, sobretudo, a 
formulação de questões, foi proposta a leitura compartilhada do conto "There are more things", de Jorge Luis Borges ${ }^{33}$. A proposta da leitura se deu com o intuito de sensibilizar os estudantes para certos aspectos do processo de conhecer, assim como para observarmos elementos que pudessem ampliar nossas discussões em torno das pulsões que mobilizam o desejo de conhecimento.

Resumo: O protagonista da história recebe a notícia da morte de seu tio, Edwin Arnett. Pouco depois, a casa de Arnett é comprada por um homem chamado Max Preetorius, que se desfaz imediatamente de todos os móveis e inicia uma série de modificações no imóvel. O protagonista, surpreendido por esses eventos, parte para investigá-los, mas não consegue obter nenhuma informação relevante das pessoas com quem conversa. Ele logo descobre que os habitantes da cidade evitam deliberadamente passar perto da casa. Numa noite chuvosa, o protagonista é pego pela tempestade e é forçado a entrar na misteriosa casa. Acendendo as luzes, descobre peças de mobília estranhas e incompreensíveis, sentindo-se em meio ao caos. Quando a chuva cessa e ele resolve sair da casa, percebe que, para sair, terá que passar pela criatura. Sua curiosidade supera seu medo e ele não fecha os olhos ao fazê-lo.

Todo conhecimento implica um ser desejante de saber das coisas, e em sua dimensão acadêmica, por princípio, o conhecimento articula-se à curiosidade epistemológica (FREITAS, 2008), dotada de rigor e método, uma vez que tal produção tem em mira a sociedade como um todo, extrapolando a esfera particular dos sujeitos. Optamos, então, por iniciar a discussão sobre o processo de pesquisa a partir da perspectiva da curiosidade. Assim, o desejo de conhecer - e seus reflexos sobre a relação afirmativa do estudante com o mundo e seus fenômenos - foi tomado como recurso mobilizador da interrogação da realidade de modo rigoroso. Para tanto, o conto intitulado em alusão à célebre frase "Há mais coisas entre o céu e a terra do que pode imaginar nossa vã filosofia" pareceu-nos ponto de partida pertinente às discussões.

De modo geral, os estudantes relataram dificuldades em construir o sentido do texto. Para a Estudante A,

o texto era uma coisa muito carregada de referências que eu nunca tinha visto na minha vida, e eu também não entendi, e acho que até hoje não entendo o que aquele texto tem a ver com pesquisa [...] é um

\footnotetext{
${ }^{33}$ Disponível em: http://varaldeleitura.blogspot.com/2014/06/conto-ulrica-de-jorge-luis-borges.html. Acesso em: 24 out. 2020.
} 
texto que não é para amadores, ele é mais difícil que, sei lá, ler Iracema.

No conto, Borges faz alusões a diferentes autores, cuja compreensão constitui o sentido do texto. As citações são espécie de recurso que estimula ramificações no pensamento do próprio leitor, assim como convida à apropriação de novos repertórios culturais. Este elemento abriu caminhos para discutir com os estudantes a leitura como um processo que, além de extrapolar a compreensão de palavras, implica o domínio de referenciais que estão na base da construção do sentido do texto. Além disso, contribuiu para discutirmos a ideia de texto, ou seja, um objeto cuja natureza é a trama simbólica da qual é dotado.

De outro lado, as referências que a obra faz ao tempo, "essa infinita urdidura do ontem, do hoje, do futuro, do sempre e do nunca", configuraram possibilidade de abordar a ampliação de repertórios simbólicos, que se dá em relação à experiência do sujeito, situado num tempo e espaço. Além de permitir explorar o fato de que essa experiência é permeada pelo próprio texto, que tanto estabelece limites visando à compreensão das ideias que carrega, como provocações ao alargamento dos contornos do conhecido, seja por meio de buscas ou da imaginação.

Conforme a Estudante D,

Eu achei que eu tinha pensado errado ou lido errado ou entendido errado e eu me senti mal, mas ao mesmo tempo eu tentei meio que ir me acalentando assim 'nossa esse autor que escreve de maneira mais complexa exige várias leituras para você entender, sabe?' Você tinha dito isso então eu acho que eu fui dizendo isso para ficar mais tranquila.

A fala é representativa de medos e dos recursos buscados para enfrentar as dificuldades do processo de conhecer. A estudante evidencia algo que extrapola a racionalidade e repousa na dimensão emocional, num sentimento de "inferioridade" intelectual.

A partir daí, discutimos sobre como o processo de construção de repertórios simbólicos implica um sujeito que se mobiliza a partir de sua curiosidade e, também, tempo e estruturas - nas quais os dispositivos estão visceralmente implicados - que acolham seu desejo de aprender e de apreender os textos. A questão nos levou a abordar a leitura, sinalizando para a importância de que uma obra seja tomada como ponto de abertura para outras obras. Ou seja, a construção do sentido de um texto implica uma 
trama articulada de sentidos, não se esgotando em si mesma, aspecto que coloca a biblioteca universitária em evidência.

A passagem a seguir, por sua vez, abriu espaço para explorarmos a questão da significação, ou seja, a construção de vínculos com o patrimônio simbólico a partir do processo do conhecimento:

[...] para ver uma coisa, é preciso compreendê-la. A poltrona pressupõe o corpo humano, suas articulações e partes; as tesouras, o ato de cortar. Que dizer de uma lâmpada ou de um veículo? O selvagem não pode perceber a Bíblia do missionário; o passageiro não vê o mesmo cordame que os homens de bordo. Se víssemos realmente o universo, talvez o entendêssemos (BORGES, s.d.).

A exploração desse trecho visava sensibilizar os estudantes para a compreensão do conhecimento como processo contextualizado. Já a afirmação "se víssemos realmente o universo, talvez o entendêssemos" levou a expormos as limitações de nosso olhar, assim como a pluralidade de perspectivas lançadas sobre o mundo e seus fenômenos.

Por sua vez, a leitura seguida de discussão suscitou a percepção do conhecimento como um processo coletivo no qual além de "conversar com os mortos"uma alusão ao diálogo com o patrimônio simbólico construído pela humanidade -, o sujeito estabelece inter-relações com os demais, as quais são essenciais à construção de diferentes dimensões produzidas pelos signos. Nesse sentido, a Estudante $G$ afirmou que

Depois que o pessoal começou a falar eu comecei a perceber as coisas que tinha e acho que o debate ajudou a entender o texto, porque lembro que cada um trouxe uma referência a alguma coisa que eu não tinha percebido e aí foi legal, a gente foi juntando as peças para poder entender o texto como um todo.

A experiência levou a estudante a constatar a importância das trocas simbólicas - com vivos e mortos. Além disso, é indicativa da importância de instituições de construção e preservação da memória cultural. Tais elementos reforçaram indagações acerca da biblioteca universitária como instância de inter-relações entre estudantes e a simbolosfera, tomadas como condição essencial ao processo do conhecimento. 
Reafirmando aspectos acerca da força da curiosidade na superação de limites à construção epistemológica, o trecho do conto "a curiosidade pôde mais que o medo, e não fechei os olhos" serviu de mote para a sensibilização dos participantes sobre o processo de elaboração da monografia final da disciplina. Assim, o objeto a ser trabalhado foi inscrito nas clássicas interrogações de pesquisa: O quê? Quem? Quando? Onde? Como? Por quê?, todavia, articuladas à esfera de desejos de conhecimento de cada um. Se há uma dimensão objetiva no processo do conhecimento, ela não está desvinculada da construção de convicções pelo desejo de conhecer, ao contrário, revela sua importância.

Em face disso, essa atividade ressaltou a curiosidade como um princípio essencial ao conhecer, mas, principalmente, levou-nos a interrogar sobre as condições das instituições educacionais e culturais para o acolhimento e estímulo à curiosidade dos sujeitos. Por sua vez, o adjetivo "epistemológica" somado à "curiosidade" indica que, ao processo do conhecimento é indispensável à aprendizagem de formas críticas e rigorosas de perscrutar o real, as quais compreendem ambientes, processos e práticas que viabilizem a liberdade de percursos e de expressão. Nessa perspectiva, a apropriação do patrimônio infodocumental implica a biblioteca universitária, uma vez que esse processo é dinâmico, diferenciado e não se dá de forma espontânea ou natural. Como todo ato cultural, implica aprendizagens específicas, contextualizadas, pautadas por princípios educacionais amplos, inscritos na esfera de formação dos sujeitos.

A experiência da leitura partilhada do conto, que exigia a compreensão de tantos outros repertórios, e as impressões dos participantes levaram-nos a interrogar sobre o lugar da biblioteca universitária na formação superior, considerado o quadro histórico dado, marcado por dificuldades ligadas à cultura letrada.

Se a sala de aula fornece uma bibliografia básica a ser trabalhada durante o curso, de caráter especializado e, portanto, fragmentário em relação à ordem do conhecimento como um todo, pensamos em que medida seria fundamental e pertinente interrogar sobre as possibilidades de a biblioteca universitária tornar-se instância de desenvolvimento de outros vínculos da comunidade acadêmica com o patrimônio infodocumental. Vinculações que extrapolem àquelas orientadas pelos contornos disciplinares, ultrapassando sua função de atendimento às demandas postas pela bibliografia básica dos cursos para colocar-se como dispositivo de comunicação cultural, capaz de responder ao desejo de conhecer de sujeitos dotados de curiosidade epistemológica. 


\section{c) Atividade 3: a busca significativa}

A terceira atividade contou com 8 participantes; 2 estudantes que não puderam comparecer agendaram outra data para realizarem a atividade. Nesse encontro abordamos processos de busca, algo solicitado pelos próprios estudantes. Foi discutida a definição do tema de pesquisa, em quais fontes costumam buscar informações e se perceberam necessidade de alteração em suas práticas de pesquisa face ao ingresso na graduação. Além disso, exploramos determinados recursos de pesquisa, apresentando estratégias de busca e evidenciando diferenças de resultados conforme a ferramenta utilizada. A discussão foi precedida pela leitura, feita pela pesquisadora, de um trecho da tese "A ordem informacional dialógica: estudo sobre a busca de informação em educação", o qual faz paralelo entre a busca informacional e a jornada do herói:

Contam as histórias que o herói se constitui sempre a partir de uma busca que ele empreende no intuito de encontrar a solução para algum problema, que não é seu somente, mas de seu grupo. Para enfrentar o desafio, ele é preparado recebendo instruções de pessoas experientes ou de entidades mágicas que o alertam e o orientam sobre os perigos de seu trabalho; de sua parte, o herói vasculha, dentre seus pares, buscando quem possa ensinar-lhe algo novo, uma habilidade especial; observa como se comportam os melhores, os mais hábeis $\mathrm{e}$ inteligentes de seu grupo; mantém guardado um segredo ou talismã para ajudá-lo em momento crítico; reflete muito; imagina saídas ou soluções mirabolantes; concentra-se; desconfia das possibilidades ilimitadas de suas faculdades/capacidades; treina e confere tudo o que sabe e que tem acumulado. Depois, sai e põe em prática o que aprendeu para enfrentar os perigos. Seu percurso é marcado por inúmeros percalços que vão sendo vencidos, ou parcialmente perdidos, até a conclusão de sua tarefa. Ao término da saga, retorna finalmente transformado pelo processo que o faz detentor de um conhecimento, um saber que tão somente ele é possuidor, mas que compartilha com os seus ao voltar. A luta com o desconhecido é tratada como um momento de intensa produção, quando os sentidos, a cognição, o raciocínio, a imaginação, os afetos, as destrezas físicas são postas em funcionamento para enfrentar e chegar ao alvo desejado. A busca é, portanto, um procedimento fundamental do conhecimento em todas as suas dimensões, propiciando a apropriação do mundo e seus segredos pelo herói, bem como a constituição do herói como sujeito único e singular. $\mathrm{O}$ eu e o mundo se integram na e pela busca. (PIERUCCINI, 2004).

A atividade confirmou a necessidade de aprender a pesquisar, de conhecer recursos, saber avaliá-los e se colocar diante deles tendo em vista obter informações consistentes, relevantes. Conforme a Estudante A, "Quem diria que umas aspas num 
sistema de busca fariam toda diferença, aquilo mudou minha vida, usar filtro de busca, sabe?”. Já o Estudante F relatou:

[...] as plataformas de busca, achei que ajudou muito, foi numa época de bastante trabalho, de bastante coisa para procurar e aí ajudou muito. Logo que você fez isso, depois que cheguei em casa eu também dei uma olhada meio que para explorar, sabe? Porque eu precisava buscar alguns materiais e já achei vários. Eu não sei se eu acharia se você não tivesse mostrado [...] foi bem produtivo para mim.

De outro lado, a atividade nos levou a observar uma dificuldade de escolhas em relação ao que desejam conhecer, aquilo que querem pesquisar quando o que está em causa não é um tema delimitado pelo próprio professor. Essa liberdade de escolha na graduação coloca alguns estudantes diante de uma prática nova: interrogar-se sobre o que se deseja conhecer no âmbito da educação formal. Ato que é propulsor da busca articulada à demanda interna, subjetiva, constitutiva de identidades.

Os estudantes destacaram certa alteração da percepção de si no processo de pesquisa, a partir da leitura do trecho anteriormente citado sobre a jornada do herói. Para a Estudante D "o texto [...] foi muito inspirador também, sabe? Não sei... deu uma vontade de fazer as coisas, de pesquisar...”. Já o Estudante J afirmou que a leitura fez “o processo de pesquisa ficar mais ilustrativo, faz você se entender participante de algo importante e não só 'ah estou fazendo uma atividade aqui e dane-se, sabe?'”.

As falas revelam a atribuição de importância à atitude comprometida com a construção do conhecimento, tomado como modo de constituição de um eu pesquisador, capaz de intervenção na ordem do conhecimento. Ou seja, a importância de que a pesquisa não seja tomada em termos individuais ou de obrigatoriedade, mas que tenha seu sentido construído a partir do reconhecimento do conhecimento como bem público e que, portanto, afeta uma ampla esfera social e compõe o patrimônio cultural existente, seja por meio de produção escrita, audiovisual, etc., seja por meio de ações no âmbito profissional.

Elaborar o significado da busca junto aos estudantes levou-os a outra esfera de percepção da pesquisa como ato de conhecer. Esse indício reforça a importância de superar perspectivas da busca competente, tomada como um fazer cujo fim nem sempre é delineado a partir do sujeito. Assim, além de se problematizar onde buscar, como buscar, como avaliar, como usar é essencial que as práticas em torno do processo de pesquisa compreendam por que desejo buscar? o que desejo conhecer?, 
questionamentos que levariam a considerar que há um sujeito inscrito no processo de busca, que seus sentidos fazem parte dele e mobilizam sua jornada do conhecimento.

Os estudantes manifestaram dúvidas e limitações quanto ao processo de busca que se referem ao uso de ferramentas, mas também evidenciaram dificuldades em delimitar e expressar desejos de conhecer face ao campo do conhecimento em que se inscrevem. Dúvidas em torno do que querem pesquisar e se conseguem pesquisar emergiram nesse processo. Tais questões nos levam a reforçar que práticas voltadas exclusivamente a ter competências informacionais para escolher a informação dita adequada, e assim usá-la, não comportam questionamentos acerca daquilo que o sujeito quer conhecer, daquilo que por vezes ele nem sabe ao certo que quer conhecer. $\mathrm{Na}$ perspectiva competente aborda-se um pesquisador pautado pela necessidade de informar-se, tendo em vista demandas por eficiência e eficácia como preconiza a ideia de competência. Nesses termos, é delicado falar-se em desejo genuíno de conhecer, isto é, quando a relação com o conhecimento está determinada pela vontade do outro. Contudo, em nossa concepção, se é preciso considerar a ideia de conhecimento incluindo a dimensão da necessidade, também é imperativo entendê-lo a partir do desejo e da curiosidade epistemológica. Esse viés é essencial ao desenvolvimento de uma biblioteca universitária que extrapole a ideia de formar um sujeito competente que sabe fazer, mas que perde de vista as mobilizações para esse fazer, as quais estão inscritas na singularidade do ser.

A experiência também ressaltou que o ato de pesquisar é um modo de relação com o patrimônio infodocumental bastante diverso daquele praticado em sala de aula. Assim, demanda do estudante uma postura a ser dinamicamente construída no processo de formação, envolvendo todas as esferas acadêmicas, em especial implicando articulações entre sala de aula e biblioteca. Nessa dimensão, há uma responsabilidade da biblioteca universitária na formação do estudante que precisa ser rigorosamente considerada. Para tanto, o diálogo com a sala de aula pode colocar-se como um caminho para a criação de possibilidades de ações que reelaborem tanto a perspectiva de conhecimento como transmissão, quanto da biblioteca como apoio ao professor e à sala de aula. 


\section{d) Atividade 4: a leitura como produção de sentidos}

$\mathrm{Na}$ quarta atividade estiveram presentes 5 estudantes. 3 outros participantes que não poderiam comparecer na data agendada solicitaram para realizarmos uma reposição. Assim, ocorreram 2 encontros, um com 5 participantes e o outro com 3. Nessa ação centramos nossas atenções em torno da prática de leitura, entendida como ato de produção de sentido a partir de diálogos com o texto. Além disso, abordamos a elaboração de fichamentos, esse recurso para reunir citações do texto lido, realizar uma análise crítica e resumir suas ideias principais organizando-as de modo que se consiga recuperá-las posteriormente. Também problematizamos o sujeito multitarefa indicando que ter foco não é prestar atenção em tudo, mas sim estar presente naquilo que se faz.

A atividade evidenciou que para os participantes o ato de leitura na educação básica era diretamente vinculado a um fim específico: ler para elaborar um trabalho pedido pelo professor, ler para estudar para a prova, ler para responder certas questões postas por outrem. Os estudantes também indicaram que o fichamento não era uma prática presente em seus processos de leitura. Portanto, guardar anotações para consultas posteriores, que extrapolassem as demandas imediatas da aula, não fez parte de suas aprendizagens e fazeres na educação básica. Contudo, alguns expuseram que a graduação demandava novas formas de leitura, sendo que após a atividade certos estudantes afirmaram terem passado a fazer fichamentos.

Essa dimensão mostrou-se ligada à incompreensão do processo de ler como ato de produção de sentidos, problema inscrito num contexto educacional que geralmente estimula a leitura para busca de informações a partir de uma demanda externa, e delineada, via de regra, pelo objetivo de reproduzir e memorizar informações. Ou seja, o ato de ler, nesse quadro, é reduzido à atividade de localização e memorização de informações, aspecto que deixa de lado o lugar do leitor na produção do sentido do texto, enquanto protagonista cultural. Observamos, também, que a leitura pode ser realizada de modo redutor caso não seja entendida e praticada como ato de ampliação de repertórios.

Ao abordar o processo de leitura a partir das questões trazidas no capítulo 2, que evidenciou a enxurrada de estímulos informacionais que marca nossas vidas, consideramos pertinente debater com os estudantes a questão do foco e da concentração. Não colocamos em causa o foco ansioso do sujeito imerso em atividades múltiplas, mas sim o foco do sujeito que se dispõe a estar presente em seus atos de conhecimento. A 
discussão que compreendeu a importância de tempo e espaço para os processos de significação foi bem recebida pelos estudantes, que se identificaram com a problemática do indivíduo multitarefa.

Assim, conforme o Estudante F,

\begin{abstract}
Acho que foi um dos melhores encontros, porque esse encontro me ajudou bastante a manter o foco e a estudar, e fazer as coisas que eu precisava fazer. Eu gostei bastante de uma coisa que não sei se foi você que falou, ou se foi o vídeo ${ }^{34}$, que foi: você prestar atenção numa coisa não é prestar atenção em duas ou mais coisas para você tentar captar tudo, não. Prestar atenção é prestar atenção em uma coisa, porque se tentar prestar atenção em várias, você não vai prestar atenção em nada.
\end{abstract}

Por sua vez, duas estudantes indicaram que, após a atividade, pararam de estudar escutando música. Além disso, houve estudante que afirmou ter reforçado para si a importância de distanciar-se do celular no momento de estudo.

A questão, além de expor o já sabido problema do sujeito multitarefa, indicou um desejo de mudança da parte dos estudantes. De outro lado, sinalizou que a relação com a informação, com o patrimônio infodocumental, implica instâncias que vão além da cognição, mas que a afetam diretamente. Além do contato com os signos, a produção de sentidos demanda instâncias educativas que efetivamente reeduquem os sujeitos no uso do tempo e do espaço face à apropriação dos objetos culturais, a partir de práticas concretas. Se estar inteiramente presente no que se faz não é algo estimulado pelas lógicas contemporâneas, a exposição e visibilidade de uma gestualidade que envolva o ato de ler pode contribuir para a construção de outras condutas públicas. Nesse aspecto, o coletivo - que funciona como espelho - pode exercer papel relevante no encorajamento ao diálogo mais profundo com os signos.

Em face disso, Giffard (apud GAUTIER, 2009 ${ }^{35}$ ) apresenta distinções entre a leitura de estudos e aquela mais amplamente realizada na World Wide Web, que nomeia como "pré-leitura". Essa leitura pode ser definida como uma espécie de escaneamento

\footnotetext{
${ }^{34} \mathrm{O}$ estudante faz referência ao seguinte recurso: CALABREZ, Pedro. Foco não é prestar atenção em tudo. Canal Casa do Saber. Disponível em: https://www.youtube.com/watch?v=yILOsgQXHjg. Acesso em: 24 out. 2020 .

${ }^{35}$ Gautier não especifica quais textos de Giffard dão base à citação. Expõe que Alain Giffard, publicou diversos artigos e ensaios sobre hipertexto, bibliotecas, leitura digital e práticas culturais da internet, sendo que alguns estão disponíveis no blog http://alaingiffard.blogs.com/.
} 
do texto, realizada num modo de atenção volátil e reativo condizente com o ambiente Web em sua dimensão instável, multidirecional e superficial. Assim, não comporta a internalização, a produção de sentidos. Para o pesquisador, há um risco de que as próximas gerações de universitários tenham essa prática de leitura como referência.

Nessa direção, Gautier (2009) contrapõe as lógicas da World Wide Web àquelas da biblioteca e dos livros, afirmando que a primeira se caracteriza como uma espécie de organismo indefinido, em reconfiguração incessante. Diante de um patrimônio líquido que desaparece sem deixar vestígios, muitos têm a percepção de que a Internet fornece "acesso a tudo" e, sob essa lógica, o que está fora da rede seria inexistente. Segundo o autor, em face dessa instabilidade, os usos da Web como instrumento de memória e, portanto, de aprendizagem a partir da memória, são dificultados.

Assim, se práticas que inscrevam o estudante em dinâmicas de ter tempo e espaço para pensar são essenciais à formação de sujeitos do conhecimento, afirmamos que a biblioteca universitária tem um papel a desempenhar, comprometendo-se com a criação de condições para os atos de significação, ultrapassando a dimensão da oferta informacional. Portanto, desenvolvida a partir de lógica diversa daquela da hiperaceleração, constituindo-se como dispositivo privilegiado da leitura tomada como ato de apropriação da memória cultural.

\section{e) Atividade 5: a síntese de informações}

Nesta atividade, que contou com 5 participantes, abordamos citações e referências de informações não textuais, em concordância com algo que todos afirmaram desejar aprender: elaborar referências conforme normas técnicas da Associação Brasileira de Normas Técnicas (ABNT). A atividade abordou o acesso e consulta às normas, mas focamos, sobretudo, na compreensão do sentido da elaboração de citações e referências, algo que escapava a uma parcela dos estudantes. Conforme a estudante D,

Quando fiz trabalho no ensino médio para mim era uma obrigação [fazer referências], aí agora ultimamente eu entendi o significado disso, que é você encontrar o autor, encontrar o texto, a referência é muito importante. Aí eu entendi a funcionalidade, você olha lá o sobrenome, o nome e vai lá no fim para ver quem falou. 
A fala, evidenciando a percepção tardia do conhecimento do sentido de citar e referenciar, sinaliza para seu impacto no processo de leitura dos textos, pois o estudante que não se apropriou dessa função está à margem de possibilidades de ampliar seus repertórios a partir da consulta às referências dos textos que lê. Além disso, indica incompreensão acerca do processo de desenvolvimento do texto acadêmico como dispositivo de comunicação científica, inscrito num sistema especializado que escapa aos não-iniciados. Para além dessa dimensão mais pragmática, a estes também escapa a percepção do conhecimento como trama construída que compreende ideias propostas por outros, a partir das quais o conhecimento se expande. Além do funcional, portanto, há uma dimensão do significado das linguagens, lógicas e protocolos de produção que são regidos por certos parâmetros, políticas e instituições. Ou seja, regidos por uma cultura que supera o aprender a empregar normas da ABNT, implicando o domínio de códigos (linguagens e idiomas) para penetrar num mundo de produção e circulação de ideias, sendo reconhecido como detentor dos cânones formais de comunicação científica.

Nesse encontro também elaboramos uma atividade em torno da síntese de informações orais para problematizar a relação do estudante com os conteúdos intelectuais apresentados e debatidos em aula. Após o convite para que assistissem a um vídeo $^{36}$ e anotassem aquilo que considerassem pertinente, discutimos o processo buscando ampliá-lo para percepções acerca da relação com os diferentes discursos em sala de aula. Assim, problematizamos aspectos em torno da tomada de notas e sua organização para recuperação posterior das informações; questão relevante na medida em que a prática de anotar a fala do professor, no ensino médio é de outra ordem: muitos estudantes fazem anotações a partir de demandas explicitadas pelo professor, como conteúdo exigido em provas, tema de trabalho final, etc.

As anotações feitas pelos estudantes evidenciaram suas dificuldades em extrair pontos essenciais abordados no vídeo exposto, além disso, alguns deixaram de anotar o que desconheciam para busca posterior. Assim, sobressaiu a importância de que as formas de relação com a informação exposta em aula sejam alvo de ações rigorosas que propiciem ao estudante condições concretas de desenvolver certos saberes e atitudes face à informação oral. Na medida em que a sala de aula é contexto privilegiado para

\footnotetext{
${ }^{36}$ DIÁlOGOS Biblioo \#5 - Briquet de Lemos. Canal Biblioo. Disponível em: https://www.youtube.com/watch?v=SdSCEU9W3KU\&feature=emb logo Acesso em: 03. dez. 2020.
} 
inter-relações com informações, observar modos pelos quais os estudantes desenvolvem meios de se relacionar com essa informação foi a base para o sentido desse encontro.

A tomada de notas, vista como processo de produção de informação, além de expor questões centrais da apropriação de ideias por meio da exposição a diferentes discursos, chama a atenção para a importância da biblioteca universitária como instância de estímulo ao diálogo com diferentes fontes informacionais. Fontes cujas estruturas e lógicas variam, implicando aprendizagens de escuta, de contemplação, de percepção e o domínio da natureza e dos modos de produção de diferentes informações. Tal preocupação se inscreve na esfera da curiosidade epistemológica, ou seja, na questão do rigor que exige saber identificar as referidas distinções. Em outros termos, aprender que as informações não são equivalentes, embora possam tratar de um mesmo tema ou objeto, faz parte da formação cultural do estudante universitário. Dinâmicas que ultrapassem aquelas de pesquisar, anotar e ler somente "o que o mestre mandou" inscrevem-se numa esfera de desenvolvimento de autonomia intelectual, que irá demandar estruturas que propiciem formação nessa direção, conferindo ao sujeito condições de elaborar relações críticas e criativas com a informação, a partir de diferentes contextos e formatos.

\section{f) Atividade 6: a (re)elaboração de si a partir da escrita}

A atividade, que contou com a presença de 7 estudantes, foi elaborada a partir do pressuposto de que a escrita é essencial à comunicação dos sujeitos nos circuitos acadêmicos de produção de conhecimento, articulando-se a sua inscrição afirmativa na ordem simbólica como alguém que significa, que dá sentido às informações. Assim, elaboramos a última atividade em torno do processo de escrita, além de aprofundarmos elementos sobre a elaboração de referências. O objetivo foi discutir com os estudantes a ordenação do pensamento diante das informações obtidas para sua comunicação, ou seja, a dinâmica entre processo subjetivo e a objetivação do conhecimento. Abordarmos a escrita como ato que se dá a partir de um ponto de partida, indicando que o autor tem uma intenção e, assim, imprime objetivos que o mobilizam nesse processo criativo. Colocar-se como sujeito a partir da linguagem escrita, seja no meio acadêmico como no próprio mundo, é ato que extrapola a escrita "a partir do que o mestre mandou", remetendo à esfera daquilo que se deseja conhecer e comunicar, da construção de identidades. 
Ao passo que a escrita é técnica fundamental para que o sujeito se relacione afirmativamente com a ordem simbólica, os resultados desse encontro nos mobilizaram para a importância de aprofundarmos a questão, o que foi feito na seção 4.2 .4 desta tese.

A Estudante A, acerca da elaboração dos trabalhos acadêmicos, relatou que

Foi muito bom ter um pontapé inicial, ter tido quem me ajudasse com meus trabalhos acadêmicos, não só você, mas bastante gente lá na sala de aula. Acho que de uma maneira geral esses encontros fizeram, não sei se só para mim, mas fizeram muita diferença, porque a gente entrou num mundo novo. Daí, sei lá, para mim foi muito gratificante saber que mesmo com tanta dificuldade eu tenho capacidade de fazer alguma coisa, tenho capacidade de estar aqui no ambiente acadêmico, tenho capacidade de me apropriar do conhecimento.

As afirmações da estudante ampliaram a compreensão em torno do fato de que o ingresso na educação superior coloca o sujeito diante de uma nova ordem de produção intelectual, na qual o domínio da linguagem escrita acadêmica é essencial ao (auto)reconhecimento do pertencimento ao meio. Quando a estudante afirma que ingressar na graduação correspondeu a adentrar num mundo novo, e que participar das seis atividades práticas possibilitou que reelaborasse a representação de si como alguém capaz de ocupar esse espaço simbólico que é a universidade, constatamos - talvez fosse mais adequado dizer que sentimos - o valor da mediação cultural como categoria articuladora de relações entre sujeitos (e seus contextos), a cultura (e suas dinâmicas) e o patrimônio infodocumental, objetivadas em passos que constituem o processo de pesquisa.

O fato de uma ação tão pontual como essa ter sido capaz de promover alguma alteração na percepção de si do estudante e, portanto, propulsioná-lo em uma nova experiência com a cultura científico-acadêmica, indica a importância de que a relação com o sistema universitário seja rigorosamente considerada na graduação, condição indispensável à formação dos sujeitos.

Assim, as atividades configuraram uma experiência que permitiu refletir criticamente sobre as relações entre socialização e participação do estudante nas esferas acadêmicas, especificamente no processo de diálogo com o patrimônio infodocumental e de produção de conhecimento. Embora tratando-se de experiência restrita, sem intuito de generalizações, ainda mais considerando as inúmeras diferenças e desigualdades que marcam o território nacional, seus indícios evidenciam que reelaborar o lugar da biblioteca universitária nos processos de relação do estudante com o patrimônio 
infodocumental implica ultrapassar barreiras procedimentais tanto no âmbito das práticas com estudantes, quanto em relação aos próprios saberes e fazeres que constituem e caracterizam esse dispositivo em sua materialidade, linguagens e processos de produção especializada.

As atividades, ao indicarem uma ordem de problemas na construção do sentido da aula, da leitura e da escrita, revelaram que a própria noção de usos do patrimônio infodocumental como base à produção de conhecimento demanda (re)elaborações junto aos estudantes, promovendo dinâmicas de construção do sentido de si como sujeito cultural. Se, de um lado, a experiência empírica comprovou a importância de aprendizagens do como fazer, de outro, reforçou que a constituição de sujeitos desejantes envolve dispositivos culturais que se coloquem como esferas de intersecção autônomas entre a cultura científico-acadêmica e a cultura dos estudantes.

Diante disso, cabe indagar em que medida um modelo social que, cada vez mais, propõe a valorização de um sujeito multitarefa em um mundo hiperacelerado em seus variados fluxos, sobretudo os informacionais, acaba reduzindo possibilidades de construção do sentido da leitura, da escrita e da escuta, do conhecimento como ato de vinculação com o mundo e com a nossa espécie, por meio de inter-relações com a simbolosfera a partir da linguagem, ou seja, da cultura? Ao que nos parece, em alguma medida esses atos vêm sendo desenvolvidos, ao longo da educação formal, em dinâmicas que perdem de vista a construção de seu sentido como essenciais à vinculação e atuação na ordem simbólica, à participação dos sujeitos na construção da memória cultural.

Quando afirmamos que lugares especialmente destinados ao desenvolvimento de relações críticas e criadoras com a memória cultural são essenciais, sinalizamos para a importância de discutir a biblioteca universitária nesses termos, considerando a especificidade que lhe é constitutiva, o patrimônio infodocumental. Assim, propor e desenvolver biblioteca na educação superior implica considerar seus públicos, a especificidade do patrimônio simbólico em causa na cultura científico-acadêmica, bem como as relações com esse patrimônio.

Essas questões demandam consideração rigorosa face ao quadro sociocultural brasileiro, com suas diferenças e desigualdades que impactam na esfera da apropriação simbólica. Se os quadros acadêmicos contemporâneos, em alguma medida, são compostos por jovens submetidos a modelos comunicacionais em que a relação com a informação é proposta de modo superficial, ao ingressarem na educação superior 
deparam-se, todavia, com uma ordem simbólica que requisita outros modos de relação, compreendendo profundidade (a especialização num campo) e amplitude (articulação de um conhecimento especializado ao todo social), como condição à ampliação da sua esfera de presença no mundo.

Nesse sentido, abordagens teóricas que caracterizam o público da biblioteca universitária a partir da noção de usuário, ou seja, como sujeito abstrato que se relaciona automaticamente com a informação, a partir de procedimentos de acesso, avaliação e uso, como se o ato de pesquisar pudesse ser, a priori, a execução de tarefa a partir de fórmula já pronta, não se sustentam num quadro em que a apropriação e renovação do conhecimento mostra-se central, como na contemporaneidade. Abordar os públicos da biblioteca universitária nesses termos é desconsiderar que o conhecimento é ato que implica sujeitos que, por sua vez, demandam processos para elaboração de sua autonomia intelectual, curiosidade epistemológica, rigor e criticidade. Atitudes essenciais ao cultivo da cultura e do conhecimento acadêmico e científico - para os quais estudantes, pesquisadores e a comunidade acadêmica como um todo são figuras centrais.

Vida e conhecimento não podem ser reduzidos a produtos, são processos. Por esta razão, essa parcela da vida do sujeito, especialmente na condição de estudante universitário, irá implicar relações com um patrimônio simbólico que ultrapassa a ordem do senso comum. Possui ordenamentos e modos de produção que demandam e permitem constituir uma cultura, com saberes e fazeres que, além de viabilizar a apropriação simbólica pelo estudante, possibilita a criação de elos com um conhecimento que permanece para além da sala de aula e da conclusão do ensino superior. Trata-se, assim, da possibilidade de desenvolver uma percepção da importância de uma outra natureza de conhecimento, cada vez mais indispensável ao agir na sociedade.

Em face disso, as atividades empíricas somam-se à literatura levantada (ADACHI, 2017; BELLETATI, 2011; COULON, 2008; TINTO, 1993) para indicar um vazio na educação superior a ser ocupado por instância especialmente concebida e metodologicamente desenvolvida para promover relações do sujeito com a informação científica e o conhecimento acadêmico. Assim, ao assumirmos a biblioteca universitária como dispositivo intrinsecamente educativo, além de suas funções como dispositivo informacional da educação superior, indicamos ser preciso avançar em proposições 
conceituais com vistas ao desenvolvimento de modelos epistêmicos que deem conta dessa complexidade.

\subsection{DISCURSOS SOBRE BIBLIOTECA UNIVERSITÁRIA: ANÁLISE DE SENTIDOS PRODUZIDOS NO BRASIL A PARTIR DE TEXTOS DO ENANCIB E DO SNBU}

A pergunta "Quais concepções pautam o desenvolvimento da biblioteca universitária no Brasil?" está na base da análise do discurso (AD) desenvolvida a partir da seleção de textos publicados nos anais do ENANCIB e do SNBU entre 2015 a 2019. A análise teve o intuito de observar efeitos de sentido que estão sendo construídos e atribuídos para a biblioteca universitária no Brasil e se dará em função de domínio científico que compreende a mediação cultural e a infoeducação.

A opção por analisar textos dos referidos eventos se deu em decorrência da representatividade de ambos no âmbito da Ciência da Informação e Biblioteconomia no país. A seleção de discursos de um evento nacional de cunho científico é pertinente à análise de concepções de biblioteca universitária, pois estabelece um painel de representações capazes de indicar modelos epistêmicos em circulação e que redundam na formação de quadros da área, potencialmente replicáveis. Por outro lado, a análise de trabalhos de um evento eminentemente profissional, voltado exclusivamente a discussões em torno da biblioteca universitária, constitui opção metodológica à apreensão de referenciais que estão na base de práticas profissionais desenvolvidas no território nacional. Nesse sentido, são reveladores das representações que animam a biblioteca universitária em contextos concretos. Tais representações são passíveis de questionamentos, face à problemática das relações entre biblioteca universitária, educação superior e patrimônio infodocumental.

“Como este texto significa?" é a questão central colocada pela análise do discurso. Logo, com ela não buscamos atravessar os textos na expectativa de encontrar um sentido no final de um percurso. Não nos interessam as marcas em si, mas seu funcionamento no discurso. Tomamos os textos não como documentos que apresentam ideias pré-concebidas, mas enquanto obras nas quais múltiplas possibilidades de leituras estão inscritas, na medida em que a AD é análise de efeito de sentidos entre locutores. Ou seja, o processo de significação é composto por emissor e receptor tomados como sujeitos linguístico-históricos, constituídos tanto pelo esquecimento como pela ideologia, esta última encarada como mecanismo estruturante do processo de 
significação. Em face disso, também buscamos escutar o não-dito nos discursos, pois mesmo aquilo que o sujeito não diz, e até mesmo desconhece, significa nas suas palavras (ORLANDI, 2012).

Nessa perspectiva, os discursos sobre biblioteca universitária não têm por função constituir a representação de sua realidade; quando muito, funcionam de modo a assegurar a permanência de certa representação. Analisamos os discursos em busca dessa representação, sem com isso pretender atingir a exaustividade em termos de extensão ou a completude de análise do objeto, aliás inviável, na medida em que os discursos não são fechados em si mesmos, mas se estabelecem em relações a outros (ORLANDI, 2012).

A delimitação do recorte de textos é constitutiva do processo da $\mathrm{AD}$, não se tratando de mera coleta, isto é, já implica posicionamentos de quem faz a análise. Em face disso, o corpus analítico, composto de 45 textos dos anais do ENANCIB e do SNBU, do período de 2015 a 2019, foi delimitado do seguinte modo:

- ENANCIB: Como não há um repositório em que seja possível efetuar buscas nos anais dos eventos a partir de palavras-chave, foi feita uma seleção de textos cujos títulos contivessem os termos biblioteca(s) universitária(s). A partir desse recorte inicial, identificamos, por meio dos resumos, textos que pudessem abordar o conceito de biblioteca universitária ou as mediações explícitas. Cabe ressaltar que, além dos textos que tratavam diretamente de práticas de mediações explícitas, foram considerados aqueles que interpretamos como capazes de contemplar essa dimensão, tanto em termo de ditos como de não-ditos. Nesse sentido, textos que discorriam sobre uso de mídias sociais, o papel do bibliotecário, processos de avaliação da biblioteca foram considerados, dentre outros. Com isso, chegamos ao total de 30 documentos. A busca foi realizada a partir das páginas on-line que abrigavam os textos dos anais ${ }^{37}$.

\footnotetext{
${ }^{37}$ ENANCIB 2015. Disponível em:

http://www.ufpb.br/evento/index.php/enancib2015/enancib2015/schedConf/presentations. Acesso em: 30 out. 2020.

ENANCIB 2016. Disponível em:

https://drive.google.com/file/d/0B7rxeg_cwHajMW9ZV0xFZHBhTnc/view. Acesso em: 30 out. 2020.

ENANCIB 2017. Disponível em:

http://enancib.marilia.unesp.br/index.php/XVIII_ENANCIB/ENANCIB/schedConf/presentations. Acesso em: 30 out. 2020.

ENANCIB 2018. Disponível em:

http://enancib.marilia.unesp.br/index.php/XIX_ENANCIB/xixenancib/schedConf/presentations Acesso em: 30 out. 2020.
} 
- SNBU: Na medida em que os trabalhos do evento se referem à biblioteca universitária, foram selecionados aqueles que traziam os termos "mediação" ou "conceito" no campo palavra-chave. Nossa pesquisa toma a biblioteca universitária como dispositivo de relações com o patrimônio infodocumental e assume as mediações explícitas como essenciais. A partir disso, fizemos o recorte pelo termo "mediação". Ao buscarmos conhecer discursos sobre a biblioteca universitária, em termos epistêmicos, filtramos pelo termo "conceito", opção feita em detrimento do termo "epistemologia" que não trouxe resultados. Com isso, chegamos ao total de 15 textos. A busca foi realizada no Repositório da Federação Brasileira de Associações de Bibliotecários, Cientistas de Informação e Instituições (FEBAB) ${ }^{38}$.

Adotamos como conduta metodológica analisar os discursos de modo não linear, a partir de fragmentos retirados de seu contexto de origem, mas preservando as respectivas redes de sentidos. A opção se justifica na medida em que consideramos ter atendido às condições básicas para tanto, como indicadas por Maingueneau:

Trata-se apenas de uma análise auxiliar, destinada a apoiar, de forma localizada, um estudo mais amplo; 2 os [...] termos-pivôs não [devem ser escolhidos] em função de um saber histórico anterior, mas definidos durante a análise. [...] preferentemente termos marcados ideologicamente; 3 . O corpus assim delimitado não pratica nenhuma violência à realidade linguística; efetivamente, não há neutralização da complexidade sintática e enunciativa, nem eliminação do contexto [...] (MAINGUENEAU, 1993, p. 135-13639 apud FREITAS, 2001, p. 72).

Assim, decidimos apresentar os fragmentos textuais indicando o título do documento, ano e evento de proveniência. Autores não foram nomeados junto aos fragmentos, pois não estava em causa analisar o discurso de um ou outro autor. Nosso objetivo foi buscar representações de biblioteca universitária nos discursos da Ciência da Informação e Biblioteconomia brasileiras no período referido. No Apêndice C,

ENANCIB 2019. Disponível em: https://conferencias.ufsc.br/index.php/enancib/2019/schedConf/presentations Acesso em: 30 out. 2020.

${ }^{38}$ Disponível em: http://repositorio.febab.org.br/items/search. Acesso em: 30 out. 2020.

${ }^{39}$ MAINGUENEAU, Dominique. Novas tendências em análise do discurso. $2^{\mathrm{a}}$. ed. Campinas: UNICAMP; São Paulo: Pontes, 1993. 
encontram-se as referências dos textos, organizadas por evento e ano. Posteriormente, trouxemos uma síntese analítica em que tramamos sentidos identificados nos distintos documentos.

Por fim, um lembrete ao leitor: esta é a nossa análise, portanto, nossa interpretação. Sempre haverá outras possíveis, na medida em que a AD implica tomada de posição de sujeitos linguístico-históricos.

\subsubsection{Os pontos da rede de sentidos}

Em suas estratégias discursivas os textos revelaram determinados termos-chave que configuram grande parte de suas redes de sentido. A partir destes sentidos, organizamos os fragmentos discursivos em seções para proceder à análise, na qual destacamos em itálico certas palavras tal qual ocorrem nos documentos selecionados.

\subsubsection{Biblioteca universitária sob perspectiva economicista}

Os três discursos selecionados defendem uma perspectiva de uso da biblioteca universitária assimilada às lógicas do modelo de capitalismo global. No primeiro fragmento "sustentabilidade, vantagem competitiva, capital intelectual são as principais características dos novos sistemas produtivos automatizados e de relação do trabalho, também entendido como a base da era da informação" (Modelagem e implantação de programa de competência em informação. 2016. SNBU).

É nesse sentido que o fragmento 2 afirma,

conhecimento e aprendizado são, respectivamente, recurso e processo estratégico no atual paradigma econômico. As rápidas e profundas transformações nas Tecnologias da Informação e da Comunicação (TIC) representam oportunidades para a abertura de novos mercados e geração de novos produtos e modelos de negócio, que se convertem em vantagem competitiva para aqueles países, empresas, instituições e indivíduos capazes de gerar, processar e usar informações para inovar, o que requer aprendizado, capacitação e acumulação contínua de conhecimentos (Ferramenta de gestão SWOT aplicada a biblioteca universitária da UFPI. 2019. ENANCIB).

Enquanto no terceiro, salienta-se que 
[...] a inovação está presente na maior parte dos produtos e serviços oferecidos no mercado. Sem a inovação, as organizações perdem espaço para a concorrência e muitas vezes a sua própria razão de ser/existir. Para inovar, a organização necessita conhecer seus clientes, suas necessidades e desejos, inclusive aqueles não revelados pelos métodos tradicionais (Design thinking: contribuições para o serviço de referência em bibliotecas universitárias. 2019. ENANCIB).

Os fragmentos revelam discursos construídos a partir de viés economicista evidenciado pelo emprego de termos como mercado, clientes, competitividade, concorrência, inovação.

Anunciando que a dita era da informação tem por base sistemas produtivos automatizados e relações de trabalho, esse espaço-tempo da biblioteca universitária aparece vinculando informação e vantagem competitiva a capital intelectual $e$ sustentabilidade, esta a palavra-mágica contra a qual não há interposições. Em igual perspectiva, o conhecimento é tratado como insumo, a ser acumulado continuamente tendo em vista objetivos de vantagem competitiva. A ideia de inovação presente nos fragmentos é outro carro-chefe das lógicas de mercado e do produtivismo e, conforme Fontenelle (2012, p. 100), encontra-se "no núcleo do processo produtivo e organizacional contemporâneo, remetendo à ideia de mudança como algo constante e permanente". A inovação tem seu sentido no âmago do processo de desenvolvimento econômico contemporâneo, sendo caracterizada como aplicação de procedimentos tecnológicos que possibilita que ideias sejam postas em funcionamento. De acordo com Fontenelle (2012), estamos diante de um momento do desenvolvimento capitalista que transformou o trabalho do conhecimento em principal força produtiva. É nesse contexto que se dá o sentido de inovação na atualidade e, como consequência, sua vinculação direta com a informação e o conhecimento, tomados como insumos a serviço da ordem econômica hegemônica.

O mundo-mercado da competitividade é também modo de ser e estar, alimentado pelos recursos simbólicos, vale dizer informação e conhecimento, postos a serviço dessa competição, isto é, tidos como bens de consumo que conferem vantagem àqueles que os possuem. Pressupõe-se uma noção de conhecimento como objeto passível de acúmulo e que confere distinção social, uma vez que o indivíduo que acumula conhecimentos é tido como superior aos que não o possuem. Nesse contexto, delineado a partir de paradigma econômico, as desigualdades são um princípio e um fim, cabendo aos sujeitos competir com os demais, distinguindo-se pela posse de conhecimentos. 
Os discursos construídos nessa lógica, revelam sua submissão à ética do capitalismo global, cuja tendência é representar o mundo, seus fenômenos e os seres como mercadorias. Ao aproximarem tal abordagem da caracterização da biblioteca universitária, tratam a relação dos sujeitos com a ordem simbólica de modo similar à relação de clientes-mercadorias. Conforme Davi Kopenawa (apud KRENAK), “o mundo acredita que tudo é mercadoria, a ponto de projetar nela tudo o que somos capazes de experimentar. A experiência das pessoas em diferentes lugares do mundo se projeta na mercadoria, significando que ela é tudo o que está fora de nós”. Nesse mundo-mercadoria tudo e todos são equiparados a valor a ser intercambiado por dinheiro, medida de equivalência para todas as coisas, e, portanto, a experiência do sujeito com a ordem simbólica tende a ser caracterizada e representada como ato de consumo.

Na medida em que a biblioteca universitária é tida como empresa, torna-se insustentável representá-la como dispositivo democrático que pressupõe inter-relações sociais e culturais entre sujeitos de palavra e patrimônio infodocumental. Ao se afirmar que informação e conhecimento conferem vantagem competitiva, estes são representados como poder do mesmo modo que o capital; bens a serem acumulados tendo em vista exercer pressão e supremacia sobre o todo social. Recusando a dimensão da partilha simbólica - inerente ao processo do conhecimento - e privilegiando a dimensão do acúmulo individual, não há como desconsiderar seus reflexos sobre pressupostos que se objetivam na ordem dos dispositivos de informação, educação e cultura.

Ao se representar o conhecimento como bem a ser consumido e acumulado, seus processos e práticas tendem a ser vistos como atividades isoladas, procedimentais, dado que a dimensão processual dos atos de conhecimento é subjugada ao princípio da oferta informacional. As insubstituíveis, singulares e essenciais relações do estudante com o patrimônio infodocumental e com outros sujeitos não conseguem ganhar centralidade no processo. Com isso, inviabilizam-se mobilizações tendo em vista o alargamento dos contornos que definem a biblioteca universitária como local de acesso à informação. 


\subsubsection{Biblioteca universitária sob o imperativo da sociedade da informação}

A influência da chamada sociedade da informação se manifesta de modo contundente sobre os destinos da biblioteca universitária, nos três fragmentos destacados. No primeiro fragmento,

A biblioteca do Século XXI deve se remodelar às exigências da sociedade da informação, adotando uma postura mais diferenciada quanto aos seus serviços e produtos, voltando-se cada vez mais para as demandas dos usuários, não importando o suporte ou localização física da informação (Biblioteca universitária e o hábito informacional dos usuários: possíveis contribuições do bibliotecário na inserção do livro eletrônico na área de saúde. 2016. ENANCIB).

As formas de adaptação da biblioteca universitária às condições da sociedade da informação são sinalizadas no fragmento seguinte, extraído de trabalho repertoriando publicações internacionais, que expõe que

Com a evolução da sociedade da informação, organizações como as Bibliotecas Universitárias (BU) tiveram que adotar um papel proativo dentro do contexto universitário, intensificando seu papel como espaços de geração de conhecimento, apoio à docência, à pesquisa, e a se envolverem no aproveitamento das vantagens das tecnologias da informação e comunicação, no uso, gestão, armazenamento e distribuição da informação (Cocriação de valor em bibliotecas universitárias: evidências nas publicações científicas internacionais. 2019. ENANCIB).

A ênfase nas mudanças no perfil da biblioteca universitária face à sociedade da informação repete-se no terceiro fragmento:

As características da sociedade atual mediada por intensa tecnologia global que, difunde de maneira rápida e abrangente novas possibilidades da informação e comunicação, através de redes determina um novo panorama nas organizações, como em nossa perspectiva, as bibliotecas universitárias (A mediação da informação e a aplicação das redes sociais pelas bibliotecas da Universidade Federal Fluminense. 2018. SNBU).

As representações destacadas colocam a biblioteca universitária como espaçotempo determinado pela informação, categoria definidora das sociedades e de seus dispositivos. A mencionada sociedade da informação é noção central aos discursos e seu emprego lança mão de referências. Ou seja, a perspectiva da sociedade da 
informação parece ter se naturalizado como questão da contemporaneidade, como fato que tão somente coloca as organizações no papel de se adequarem a uma ordem, por princípio abstrata, mas que comanda dinâmicas socioculturais concretas. Em decorrência disso, ao se marginalizar reflexões sobre bases epistemológicas que estruturam e embasam essa sociedade, observa-se uma ruptura com a regra fundamental do funcionamento do discurso científico, que pressupõe que a busca da verdade implica desvelar a autoridade do discurso. Nesse aspecto, Freitas (2001) interroga se o apagamento da autoria seria recurso para a criação de discursos fundadores, pautados em crenças assim como no discurso mítico.

Se a biblioteca universitária deve, tem que realizar adequações face ao imperativo informacional e tecnológico, via de regra vantajosas ao seu papel sociocultural, reconhecer seu caráter de dispositivo cultural torna-se parâmetro ao cumprimento de objetivos que a determinam. Os termos destacados avolumam um discurso que deixa de lado problematizações centrais, considerando-se a natureza educativa deste dispositivo. Natureza esta que se contrapõe a essa sociedade em que a tecnologia oferece vantagens para gerir e distribuir informações num circuito hiperacelerado, pautado por lógicas mercadológicas.

Para além das finalidades declaradas de atendimento à demanda dos usuários e de acesso irrestrito a informações, há que se introduzir o debate que tome a biblioteca universitária a partir de modelo comunicacional capaz de compreender a problemática da significação. Diante da aparente utopia, a crítica ao modelo adaptativo é um caminho a possibilidades de reversão da supremacia da ordem informacional orientada pelos interesses dessa sociedade da informação.

\subsubsection{Biblioteca universitária sob a perspectiva das funções técnico-especializadas}

As representações permitem identificar diversificada gama de funções essenciais compreendidas pela biblioteca universitária. O fragmento 1 expõe que "as bibliotecas universitárias apresentam-se como lugar de memória, de tradição e de práticas culturais. Assim, podemos entendê-la (sic) como espaço onde nosso patrimônio material e imaterial é captado, preservado e disseminado" (Biblioteca universitária: sua função social enquanto lugar de memória. 2016. SNBU). 
Na perspectiva do fragmento 2, “a biblioteca universitária é um instrumento fundamental de apoio à pesquisa, e a ela 'especificamente compete fornecer informações em níveis compatíveis com as necessidades dos usuários, como apoio imprescindível às atividades de ensino, pesquisa e extensão"” (O papel da biblioteca virtual na mediação do ensino à distância. 2018. SNBU).

Os trechos acima colocam em relação duas funções importantes, exercidas pela mesma natureza de dispositivo. Ao caracterizar a biblioteca a partir da memória cultural, o discurso afirma sua importância para nós, seres que simbolizam. No discurso a biblioteca universitária é lugar para relações com a produção simbólica de nossa espécie, tendo como função captá-la, preservá-la e disseminá-la. Assim, é enunciado que não há memória espontânea, sendo preciso criar dispositivos para sua construção, a partir de uma modalidade que exerça funções de conservação e difusão, que podem ser entendidas como essenciais às dinâmicas de produção da memória cultural. Ao indicar que a biblioteca capta, preserva e dissemina o patrimônio material e imaterial da nossa espécie, o discurso revela a memória como construção e a biblioteca como dispositivo afirmativo atuante nesse processo.

A biblioteca universitária é, no segundo fragmento, representada a partir da função de fornecer informações, conforme necessidades de seus usuários; a partir da oferta informacional, apoia pesquisa, ensino e extensão. Nessa perspectiva, o papel de apoio confere-lhe caráter acessório, de atendimento a necessidades definidas pelo projeto educativo. De modo complementar, na medida em que a biblioteca atende necessidades, demandas "de fora para dentro", cabe interrogar o próprio sentido da necessidade, em que contextos surge e se expressa. São as prerrogativas de uma formação voltada exclusivamente ao mercado de trabalho, ou de uma formação cultural e social mais ampla?

De qualquer forma, ambos os discursos enunciam a função da biblioteca a partir do objeto que a caracteriza e a distingue das demais instituições de memória e/ou informação no âmbito da cultura letrada. Se o objeto da biblioteca universitária é representado tanto pela memória cultural - como repositório simbólico da humanidade -, quanto pela informação, há aí uma questão que não se resolve conceitualmente, dado que a abordagem e constituição dessas matérias simbólicas demandam concepções e metodologias distintas e específicas. Contudo, a consideração a essas duas vertentes permite entrever um debate essencial aos rumos da própria biblioteca e de seu campo do conhecimento que, parece, mostra-se urgente na contemporaneidade. Trata-se de 
questão central uma vez que, tendo o paradigma informacional como eixo, a biblioteca atrela-se à disseminação e à aceleração dos fluxos e dos usos, como definido pela Biblioteconomia da modernidade e pela noção de sociedade da informação na atualidade. Por seu turno, ao afirmarmos que a memória cultural é um eixo central da biblioteca universitária, reconhecendo sua especificidade científica, indicamos a apropriação do patrimônio infodocumental, as dinâmicas de sua reconstrução e a inserção dos sujeitos nesse processo como aspectos que não se resolvem pelo distributivismo simbólico. Portanto, estabelecer a proposição de revisões, novos produtos, serviços e fazeres para a biblioteca universitária, desconsiderando uma nova episteme que a oriente, é reduzir possibilidades de (re)elaborar funções que impactem a própria relação patrimônio infodocumental e sociedade, em especial a comunidade acadêmica.

O terceiro fragmento indica uma outra função que ganha relevância, à medida que na atualidade o volume informacional aumenta significativamente:

[...] as bibliotecas produzem conhecimento sobre o conhecimento, informação sobre as informações, interdocumentos sobre todas as mediações e inscrições (documentos, artefatos e coleções; informações cadastrais e referenciais); participam das formas estabelecidas de validação e credenciamento da produção do conhecimento (Universidade e biblioteca universitária no Brasil: o caso da Biblioteca Central do Gragoatá da Universidade Federal Fluminense. 2017. ENANCIB).

A produção de meta-informação configura outro papel da biblioteca universitária face às funções de conservação da memória cultural e de disseminação de informação. Assim, é representada como instância de editoração, com responsabilidade sobre a validação e credenciamento da produção do conhecimento. O discurso representa a biblioteca universitária a partir do exercício de seu papel de construção do patrimônio infodocumental que, face à produção crescente, demanda instituições, processos e práticas consolidadas nesse sentido. A produção de meta-informação, ao implicar validação e credenciamento do conhecimento, revela que suas práticas não são neutras. Como dispositivo cultural, a biblioteca é marcada pela intencionalidade e, se inclui certos conteúdos intelectuais em seus repertórios, exclui outros a partir de determinados critérios que resultarão na memória cultural considerada.

No fragmento 4, o eixo se amplia, incluindo outra representação que considera que 


\begin{abstract}
A biblioteca universitária deve contribuir para que os estudantes sejam incluídos na universidade e na sociedade, bem como para estimular que eles sejam sujeitos críticos que também influenciem a definição de novas práticas de informação na Universidade [...]. O tradicional papel da biblioteca universitária deve, hoje, passar por uma revisão para atender a outras demandas que não as exclusivamente oficiais (Práticas documentárias em bibliotecas universitárias: questões para o debate sobre políticas de informação. 2018. ENANCIB.).
\end{abstract}

Sob essa perspectiva a função da biblioteca universitária é delimitada a partir dos sujeitos. Ela deve contribuir para a inclusão dos estudantes na universidade e na sociedade, em perspectiva crítica. Ao afirmar o papel da biblioteca na formação de um sujeito crítico que seja incluído na universidade e na sociedade, o discurso revela a biblioteca como instância que o propulsiona para dinâmicas sociais e culturais em outros contextos. $\mathrm{O}$ discurso indica o encontro dos estudantes com a biblioteca como uma relação de trocas mútuas, na medida em que estes são vistos como influenciadores das práticas de informação na universidade, indicando ao leitor a importância de que este encontro seja mote para revisão da própria biblioteca universitária.

Os fragmentos discursivos evidenciam diferentes pontos constitutivos dos sentidos de biblioteca universitária. Conforme apontado, as representações revelam amplitude na atribuição de suas funções, que englobam o patrimônio infodocumental. Assim, há abordagens de conservação, difusão, editoração e função educativa diretamente atreladas à problemática da apropriação cultural, que alteram, consequentemente, as perspectivas discursivas em torno da ideia de acesso à informação.

\title{
5.2.1.4 Biblioteca universitária sob perspectiva das TIC
}

A temática das tecnologias de informação e comunicação é encontrada no universo de representações acerca da biblioteca universitária, conferindo novas responsabilidades e desafios a esse organismo na contemporaneidade, assim como apresentado no fragmento 1 , ao indicar que "as tendências para o futuro das bibliotecas em geral relacionam-se intrinsecamente com o desenvolvimento das tecnologias digitais" (Tendências para o futuro da biblioteca universitária pública brasileira. 2019. ENANCIB). 
As TIC são representadas como categoria que interfere nos processos comunicacionais da biblioteca na contemporaneidade, com o chamado usuário exercendo papel presumido e desejado, conforme disposto no fragmento a seguir:

[...] o interesse das bibliotecas está se voltando para as tecnologias que podem melhorar o funcionamento interno e externo das unidades, tendo como pontos-chave para o seu desenvolvimento os usuários e como a informação é transmitida para eles. A inserção de tecnologias, como as disponibilizadas pela Web 2.0, pode tornar a biblioteca ativa aos olhos do público, uma vez que essas ferramentas tecnológicas podem conectar o usuário remoto aos serviços e produtos que a biblioteca disponibiliza a ele (Biblioteca universitária híbrida no contexto da web 2.0: integração de ferramentas para a promoção de produtos e serviços. 2016. ENANCIB).

Também no terceiro fragmento, as TIC aparecem como meio de aproximação da biblioteca com os públicos universitários:

[...] faz-se importante agir de acordo com esta nova era digital e de acordo com o novo perfil dos usuários das BUs, que estabelece uma maior interação social, gera e compartilha conhecimento, assim como uma inteligência coletiva. Isso porque, com essa nova era digital, fazse indispensável - e é muito bom para as bibliotecas - o uso das mídias e entretenimento dos seus serviços para chamar a atenção dos usuários e fazer destes espaços lugares mais atraentes, além de aportar conhecimento e cultura para a sociedade (Inovação no contexto das bibliotecas universitárias: uma análise da evolução cultural no processo de desenvolvimento de serviços informacionais. 2017. ENANCIB).

O emprego da palavra tendências, conforme disposto inicialmente, evidencia "disposição natural" da biblioteca "a seguir certo caminho" (TENDÊNCIAS, 2020) o qual, por sua vez, estaria determinado pelas tecnologias digitais, que condicionam sua existência no futuro. De acordo com a colocação, é possível afirmar que sem o uso das tecnologias digitais a biblioteca - universitária ou não - irá desaparecer. A afirmação contundente parece não distinguir biblioteca de sistemas de informação digitais, colocando nos mesmos termos a natureza e sentido do patrimônio infodocumental e os recursos e técnicas que veiculam registros de informação. Se as tecnologias de informação e comunicação são elementos centrais da ordem cultural contemporânea, sua aplicação no universo da produção do conhecimento mostra-se essencial, conforme já discutido. Todavia, é necessário colocá-las em perspectiva, sob o risco de considerável confusão epistêmica. 
As TIC, como no fragmento 2, são representadas como elementos-chave para a transmissão de informações pelas bibliotecas, condição para que estas sejam vistas como ativas pelo seu público, exercendo papel diverso daquelas não híbridas, percebidas como inativas, sem funções a desempenhar num tempo definido pelas tecnologias. A essas representações, agrega-se outra que confirma a percepção do imperativo tecnológico sobre as bibliotecas ao expor a era digital como o novo que se impõe a esses dispositivos, que devem agir conforme seus desígnios.

A consideração à nova era, prescindindo de referências e argumentações, torna certas compreensões absolutistas e dispensa problematizações fundamentais ao significado da biblioteca universitária, questão que ultrapassa sua dimensão tecnológica. De acordo com o disposto, a nova era digital está dada, simplesmente é. Os discursos a caracterizam como verdade absoluta, cabendo à biblioteca universitária seguir seus desígnios para que se integre ao novo tempo. Trata-se, no entanto, de discurso que, segundo Sievers (2007), inscreve-se numa lógica emergente a partir de insuficiências e falhas dos meios tradicionais de transformação organizacional e de maximização dos lucros no capitalismo, propagando a ideia de inovação como algo indispensável, atrelado a mudanças permanentes e constantes. Essa era digital é delimitada a partir de discurso tecnológico moderno, que sublima a lógica do modelo industrial, capitalista e seriado, que consome diferenças sob o pretexto de permitir entrar numa era de facilidades e de direitos iguais.

Daí a correlação e o alinhamento às lógicas das mídias digitais, que as elevam a categoria indispensável, recursos empregados para entreter e chamar a atenção de seus usuários. Delineada a partir das TIC, a função da biblioteca tem como base modelos que pautam dispositivos de comunicação desenvolvidos por empresas que tomam a relação do sujeito com a informação como consumo sígnico, incluindo o entretenimento; noção surpreendente neste contexto face a sua correspondência com as ideias de "distrair, fazer voltar a atenção, iludir, enganar com artimanhas" (ENTRETENIMENTO, 2020). A perspectiva ora em causa parece-nos revelar um fenômeno indicado por Han (2019, p. 202-203), para quem o entretenimento não é mais episódico, mas, por assim dizer, crônico. Ou seja, "ele parece não mais dizer respeito apenas ao tempo livre, mas também ao próprio tempo", como se estivesse sorrateiramente sendo totalizado como uma "nova experiência do mundo e do tempo", incluindo-se aí a experiência de relação com o patrimônio infodocumental na educação superior. As tecnologias parecem ter impactado não só o sentido do espaço, mas 
também do tempo, com a emergência de ritmos acelerados de vida, impostos pelas dinâmicas tecnológicas informacionais. O templo cíclico, ritualístico, renovável aparece sobreposto por um tempo linear, em que o mundo e seus fenômenos são sempre iguais. Assim, emerge a força do entretenimento num tempo em que a contemplação que implica o olhar, a escuta, o envolvimento (consigo e com o outro) acaba por se diluir num "eterno novo".

\subsubsection{Biblioteca universitária na perspectiva da comunicação midiática (as mídias sociais digitais)}

Assim como apontado anteriormente, em relação às TIC, as representações das relações entre bibliotecas universitárias e mídias sociais ganham relevância nos discursos da área. $\mathrm{O}$ fragmento a seguir mostra que

[...] acompanhando esse novo cenário, as bibliotecas universitárias podem usar as mídias sociais na divulgação de seus serviços (e algumas já o fazem), vindo a conhecer as necessidades de seus interagentes, fomentando o uso de seu acervo, serviços e produtos de informação (Competência em informação digital: o ponto de vista dos bibliotecários gestores das bibliotecas universitárias da associação catarinense das fundações educacionais. 2016. ENANCIB).

Na mesma direção, outro fragmento indica que

[...] faz-se necessário refletir acerca desses ambientes [mídias sociais digitais] como ferramentas que oferecem a oportunidade de ampliar a promoção dos serviços e produtos das unidades de informação, sobretudo das bibliotecas universitárias. Atreladas aos conceitos de marketing, essas mídias oferecem possibilidades de estreitamento dos laços entre a biblioteca e seus usuários, uma vez que se constituem como canais de comunicação mais direcionados e interativos $(\mathrm{O}$ uso do facebook para a divulgação dos serviços das bibliotecas universitárias federais do nordeste. 2016. ENANCIB).

Ainda de acordo com um terceiro discurso,

[...] um dos objetivos que impulsiona o gestor e demais bibliotecários a adotarem um dispositivo de comunicação da web social é contribuir com o desenvolvimento dos usuários, ampliando a recuperação, o acesso, o uso e a apropriação da informação. As atividades de mediação realizadas nos dispositivos que estão ligadas à informação podem ter como base a gestão da informação, o que faz com que o 
gestor e o agente se conscientizem de suas ações mediadoras, aspecto necessário para mediar a informação (Atividades de gestão nos dispositivos de comunicação da web social das bibliotecas universitárias brasileiras. 2016. ENANCIB).

Como se vê, tais discursos não escapam do imperativo da sociedade da informação, pois abordam o uso das mídias sociais digitais como recurso para melhoria dos processos comunicacionais da biblioteca universitária, evidenciando preocupações nessa direção. Nesse sentido, o uso das mídias sociais é representado como forma de acompanhar um novo cenário, estabelecendo, nesses termos, contraponto com um velho cenário "que existe há muito tempo" e "que está fora de moda; antiquado, obsoleto, ultrapassado" (VELHO, 2020). Por essa via, as mídias sociais são representadas como ferramentas que, por meio da divulgação e promoção de serviços e produtos, permitiriam a salvaguarda da biblioteca universitária.

Ainda que indicada a possibilidade de inserção dessas mídias - canais interativos - para estreitamento de laços entre biblioteca e seus públicos (fragmento 2), essa interação é proposta a partir da promoção de serviços e produtos, algo semelhante ao discurso de fidelização do consumidor, prática que toma a interatividade como categoria de modelo comunicacional de envio de informações a um receptor. A ferramenta é representada como nova forma de comunicar o já existente na biblioteca, não sendo proposta como caminho para o desenvolvimento de novas práticas.

Uma outra representação se agrega ao espectro relativo às mídias sociais digitais, indicando-se o seu uso como forma de contribuir com o desenvolvimento dos usuários, colocados como objeto. Contudo, ao se avançar na abordagem das reflexões sobre atividades, o discurso se volta à gestão da informação como base para ações de mediação nas mídias sociais. Ou seja, centra-se em informações a serem geridas e não tem como objeto, propriamente, as relações dos sujeitos com a informação e entre si. O discurso em causa representa a gestão de informações como atividade ligada à esfera de produção, não comportando a noção de relação dos sujeitos com o patrimônio simbólico. Assim, remete à ideia de que o emprego dessas ferramentas tecnológicas bastaria para caracterizar uma biblioteca universitária condizente com seu tempo, perspectiva redutora se entendemos a biblioteca como potencial meio propositivo de transformações da ordem cultural de seu contexto.

O emprego das mídias sociais digitais é proposto para o envio de informações sobre produtos e serviços já existentes, não são pensadas como condição de 
possibilidade para um serviço da biblioteca que tenha como base inter-relações entre sujeitos e ordem simbólica em perspectiva crítica e afirmativa. Portanto, a lógica que delineia o desenvolvimento de tais ferramentas - divulgar produtos e serviços de empresas, de pessoas -, mantém-se em discursos da Ciência da Informação. Tal aspecto equipara visões sobre organismos de natureza diversa, confundindo papéis e finalidades dessas mídias nas bibliotecas universitárias, ambientes eminentemente educativos, pautados por lógicas não comerciais.

\title{
5.2.1.6 Biblioteca universitária, informação e significação
}

Como não poderia deixar de ser, as representações sobre o patrimônio simbólico apresentam variações. Assim, no primeiro fragmento é colocado que

\begin{abstract}
A informação, no cenário atual, representa componente primordial para as organizações; sua aplicação possibilita que as empresas tenham vantagem competitiva e escolham a melhor estratégia, a fim de se manterem atuantes no mercado. [...] a informação adquiriu um papel econômico, pois se tornou insumo ao desenvolvimento de produtos, à captação de recursos, ao conhecimento de mercado e à própria sobrevivência das empresas (Competência em informação digital: o ponto de vista dos bibliotecários gestores das bibliotecas universitárias da associação catarinense das fundações educacionais. 2016. ENANCIB).
\end{abstract}

A perspectiva em questão representa a informação como insumo, servindo a um propósito delineado a partir de um viés economicista. Assim, com a informação é possível adquirir vantagem e manter-se atuante em um circuito representado a partir do termo mercado. Se, de um lado, o discurso evidencia a lógica do capital empregada para caracterizar a informação, em perspectiva alinhada com aquela que apresentamos anteriormente, na seção A biblioteca universitária sob perspectiva economicista, de outro, cabe reforçar que tais discursos se dão num texto de análise sobre a biblioteca universitária. Daí que no não-dito a biblioteca é caracterizada como instituição importante, ou com potencial de tornar-se importante, na medida em que é dispositivo privilegiado de sistematização e disseminação de informações, as quais possuem papel econômico. Ao valorizar a informação, o discurso busca delimitar o valor da biblioteca universitária, todavia, a partir de modelo em que o mundo, seus fenômenos e elementos são vistos como mercado. 
Entretanto, concorrem com essa outras representações divergentes, indicando o valor imanente do conhecimento e da cultura, conforme aponta o fragmento 2: "assumiu-se como perspectiva o reconhecimento da importância que deve ser dada nos estudos informacionais às experiências dos sujeitos, uma vez considerando a informação como construção social" ("A biblioteca deveria estar do nosso lado": com/sobre quilombolas e indígenas e suas relações com a biblioteca universitária. 2019. ENANCIB). Assim como o fragmento seguinte:

[...] as bibliotecas se mostram capazes de enunciar ou exibir uma série de construções culturais cujos referenciais expressam de maneira significativa as estruturas históricas, políticas, ideológicas e identitárias sobre as quais uma dada sociedade se constitui, nutre-se e se valoriza (Biblioteca universitária: sua função social enquanto lugar de memória. 2016. SNBU).

Representar a informação como construção social significa ampliar o debate sobre a natureza do signo e a dimensão política da informação, entendida como processo de transformação dos fenômenos em signos. A perspectiva ressalta a importância da experiência dos sujeitos nos estudos informacionais e, nesse contexto, a informação é representada como processo, implicando tanto a atuação das esferas de produção como as da recepção. O discurso considera as singularidades dos sujeitos, na medida em que os sentidos da informação são delineados a partir da experiência de cada um. Nesses termos, aqui a sistematização e disseminação do patrimônio infodocumental pelas bibliotecas universitárias se dá considerando as inter-relações dos sujeitos com essa ordem simbólica, a partir das singularidades e particularidades, na medida mesma em que considera a dimensão da experiência.

O terceiro fragmento aborda a relação patrimônio infodocumental-biblioteca, considerando que a matéria simbólica que esses dispositivos organizam expressa estruturas das sociedades em que se inserem em termos históricos, políticos, ideológicos e identitários. O discurso evidencia compreensões que incluem e avançam sobre a proposição anterior, ao explicitar a informação como construção que se dá a partir de dadas perspectivas, as quais afetam a composição dos acervos das bibliotecas que, por sua vez, nutrem e valorizam as sociedades. Esse modo de representação da informação abre espaço à dimensão de dispositivo dos acervos, indicando dinâmicas de memória e esquecimento implícitas na ordem social do conhecimento. 
Os fragmentos com perspectivas distintas remetem a problematizações acerca da noção de patrimônio simbólico inscrita na Ciência da Informação e Biblioteconomia brasileiras. Desta forma, é inescapável e imprescindível discutir e descrever as diferentes noções em concorrência na área, pois considerar informação como construção social, compreendendo a experiência do sujeito, ou como bem simbólico já acabado a ser acessado por alguém, tendo em vista a obtenção de vantagens, implica perspectivas divergentes, se não antagônicas. Definir a biblioteca universitária face ao século XXI, demanda interrogar qual a noção de patrimônio simbólico que perpassa as representações desse dispositivo, vinculado à educação superior e aos processos do conhecimento acadêmico, portanto, intrinsecamente educativo.

\subsubsection{O estudante}

Nos discursos da área, há representações sobre a biblioteca universitária que abordam a figura do estudante como categoria implicada em seus aspectos epistêmicos e procedimentais. Sobre isso, o fragmento 1 sinaliza que

[...] a biblioteca universitária passou a ser frequentada por outros públicos não familiarizados com as práticas culturais de uma biblioteca, tampouco com os hábitos de leitura de uma universidade. [...] Este público é formado, sobretudo, por jovens habituados com os usos das tecnologias de informação e comunicação, mas que não sabem aplicá-las nas bibliotecas, ou não têm competência crítica para utilizar esses recursos no contexto universitário (Práticas documentárias em bibliotecas universitárias: questões para o debate sobre políticas de informação. 2018. ENANCIB).

A essa representação, pode-se articular a abordagem seguinte, que afirma que

A deficiência do ensino no contexto social brasileiro faz com que o aluno entre na universidade sem o hábito de pesquisa, e na educação a distância não é diferente. A imagem do estudante auto-suficiente (sic), versátil, que tem habilidades de pesquisa é um mito (O papel da biblioteca virtual na mediação do ensino à distância. 2018. SNBU).

Os fragmentos salientam que o público da biblioteca universitária, sobretudo os estudantes ingressantes, encontra-se desprovido de formação adequada para participar das dinâmicas acadêmicas, apresentando lacunas que afetam relações com a ordem simbólica universitária. Assim, os estudantes não estão familiarizados com as práticas 
culturais de bibliotecas ou com hábitos de leitura na universidade, ingressando na educação superior sem que tenham desenvolvido práticas de pesquisa de modo consistente. Mesmo se habituados ao uso de TIC, os jovens que ingressam na graduação não sabem, necessariamente, fazer uso delas no contexto universitário, não sabem aplicá-las nas bibliotecas. Além de tratar de um novo circuito no qual o sujeito ingressa, o discurso afirma a insuficiência de saberes para que nele se relacione de modo afirmativo. Essa questão, conforme abordado (fragmento 2), caracteriza como mito a imagem do estudante autossuficiente que ingressa na educação superior, declarando, então, que não estão prontos para realizar pesquisas, algo diretamente atrelado à deficiência do ensino no contexto social brasileiro.

A autossuficiência e a habilidade de pesquisa na educação superior demandariam uma educação básica que abordasse a relação do estudante com a informação e o conhecimento, em seus diferentes dispositivos. De outro lado, também implicaria uma educação superior que rompesse com a imagem fantasiosa do estudante já pronto, buscando formá-lo para desenvolver novas formas de relação com a ordem simbólica. Portanto, mais que concepções ou a familiarização com uma nova cultura, a questão demanda o desenvolvimento de projetos educacionais amplos que tenham por base processos de produção de conhecimento e de apropriação simbólica os quais compreendam concepções de ensino, de conhecimento e de seus respectivos dispositivos, tais como a sala de aula e a biblioteca universitária.

Articulado à figura do estudante, há discursos que remetem ao papel do bibliotecário e seus respectivos serviços na biblioteca universitária. No fragmento a seguir, considera-se que "o papel do bibliotecário mediador é atender às necessidades informacionais dos usuários imediatos e potenciais de forma a estabelecer uma dinâmica entre os repositórios estáticos de conhecimento e as questões vividas pelos usuários na busca do conhecimento" (Bibliotecário e a mediação da informação: serviços de referência do presencial ao virtual. 2018. SNBU).

Em outro, salienta-se que o serviço de referência é "o setor responsável pela comunicação e compartilhamento do conhecimento institucional com seus usuários/clientes, que interage e percebe o mercado (demandas informacionais e científicas) como ele é" (Gestão do conhecimento e gestão do conhecimento científico em bibliotecas universitárias: uma revisão atual. 2016. SNBU).

Complementando os destaques discursivos, o fragmento a seguir considera que "a tarefa das bibliotecas e demais centros de informação não é apenas a de satisfazer as 
necessidades de informação momentâneas dos usuários, mas a de procurar inovar na oferta de produtos e serviços que sejam capazes de atender aos interesses da clientela no futuro" (Biblioteca universitária híbrida no contexto da web 2.0: integração de ferramentas para a promoção de produtos e serviços. 2016.ENANCIB).

As abordagens implícitas nos três discursos acima afirmam que o público das bibliotecas universitárias possui certas necessidades, demandas informacionais específicas que cabem à biblioteca suprir, destacando-se à vinculação que um deles faz entre essas necessidades e a busca do conhecimento. Ao representar um sujeito em busca do conhecimento, o discurso indica alguém que procura algo pronto; o estudante não é representado, portanto, como sujeito que produz conhecimento. Já as necessidades informacionais inscrevem-se num contexto que caracteriza o sujeito como usuário alguém que "utiliza algo; que tem o direito de uso, mas não a propriedade" (USUÁRIO, 2020). Assim, remete ao direito de uso da biblioteca e do patrimônio infodocumental que viabiliza, mas não à ideia de apropriação cultural, na medida em que a apropriação é transformar aquilo que se recebe em algo próprio, a partir de nossas experiências. (CHARTIER, 1999). Se a definição de usuário remete para relações com a informação em termos materiais de acesso e uso, o emprego deste termo para caracterizar a comunidade da biblioteca universitária é limitante para representar a relação do sujeito com o patrimônio infodocumental, compreendida como produção de sentidos.

Chama a atenção o fragmento seguinte, que se refere à autoimagem dos estudantes em relação à biblioteca universitária, sobretudo por se tratar de discurso inscrito em documento que indica tratar de revisão de literatura sobre biblioteca universitária. Conforme sintetiza, "os estudantes irão cada vez mais se ver como clientes e consumidores, que esperam por instalações e serviços de alta qualidade" (O futuro da biblioteca universitária: tendências da revisão de literatura. 2017. ENANCIB).

O discurso representa os estudantes como clientela, cliente, consumidor de um mercado de serviços para o qual apresentam demandas informacionais e científicas. Nesse fragmento presume-se que ao se (re)elaborar como cliente e consumidor da biblioteca universitária, o estudante demandará serviços e instalações de alta qualidade. Contudo, tais serviços e instalações não devem ser confundidos com práticas de facilitação ao consumo de informação, mas, ao contrário, podem implicar configurações nem sempre reconhecíveis pelo estudante, dado o fosso cultural que marca a relação biblioteca-sociedade no país. A análise do que não está dito, mas pressuposto, indica que para oferecer instalações e serviços de alta qualidade a biblioteca precisaria passar 
a caracterizar seu público como consumidores e clientes. Cabe destacar que o cliente é aquele que compõe a freguesia, "o conjunto de pessoas que frequentam habitualmente uma loja, para fazer suas compras, consumações, etc., que se utilizam dos serviços de um profissional" (NASCENTES, 2011, p.179). Nesses termos, os discursos caracterizam a relação do estudante com o patrimônio infodocumental a partir da perspectiva do consumo, incompatível com a noção de biblioteca no contexto de produção acadêmica.

Se o cliente remete à imagem da "biblioteca mercado", aquela que oferece o cru (a informação) para um indivíduo, o estudante remete à imagem da "biblioteca cozinha", compreendendo sua matéria como insumo ao processo do conhecimento, ao “cozimento" a ser realizado por sujeitos em inter-relações com os outros, o mundo e seus fenômenos, e o patrimônio infodocumental ${ }^{40}$. Para o desenvolvimento de uma biblioteca universitária que tenha sua função educativa de fato considerada, é primordial ultrapassar representações de seus públicos como clientes, tomando-os como estudantes, educadores e pesquisadores.

Nessa direção, não se pode desconsiderar que as IES prestam um serviço a um público específico e não a toda a sociedade. Assim, em alguma medida, a cultura de serviço faz parte da estrutura acadêmica e, via de regra, o comprometimento institucional não faz parte do gesto de ser estudante. Diante disso, elaborar-se e ser caracterizado pela própria IES como produtor de conhecimento na cultura científicoacadêmica, poderia ser um caminho à mudança desse viés institucional de prestação de serviço que se coloca sobre a educação superior e, em decorrência, sobre a biblioteca universitária.

\subsubsection{Biblioteca universitária e interculturalidade}

A questão da interculturalidade e do diálogo com a diferença, assim como as possibilidades de relação com amplo universo de ideias, a partir da biblioteca universitária, foi considerada dentre os discursos coletados. Sobre a problemática da interculturalidade, todavia, um único documento (fragmento 1) fez referência, elaborando o seguinte:

\footnotetext{
${ }^{40}$ Paralelo com a metáfora feita por Claude Lévi-Strauss e apresentada por Burke (2012, p. 14), segundo a qual "poderíamos pensar na informação como o cru, enquanto o conhecimento seria o cozido".
} 
[...] refletir sobre a presença indígena e quilombola na biblioteca e na universidade, mas evidenciando que eles não são o "foco do problema", e sim as relações de poder, como em todas as instituições mas, em especial, nesses espaços marcados pela cultura erudita, de culto à leitura e aos objetos escritos ("A biblioteca deveria estar do nosso lado": com/sobre quilombolas e indígenas e suas relações com a biblioteca universitária. 2019. ENANCIB).

O conceito de interculturalidade é apresentado em contexto que coloca a biblioteca universitária como pertencente e representativa da cultura erudita dominante no meio acadêmico, cujas formas e linguagens implicam domínio de referenciais não partilhados por todos os grupos culturais. Tais defasagens refletem e refletem-se em relações de poder e em formas de distinção entre grupos, caminhando em sentido contrário ao princípio da democracia cultural. $\mathrm{O}$ enunciador afirma existir uma distância entre biblioteca, indígenas e quilombolas delineada a partir da linguagem escrita, representativa dos acervos das bibliotecas. Confirma, assim, que o foco do problema não é o indígena ou o quilombola que usa a biblioteca, mas as perspectivas que caracterizam esses públicos como problema, um obstáculo ou desequilíbrio à ordem simbólica preconizada pela biblioteca universitária.

Logo, não é problematizado somente o diálogo do sujeito com uma ordem simbólica, mas a própria configuração dessa ordem e suas formas, representativas de relações de poder, sendo identificada uma tensão que implica dinâmicas de interações sociais e culturais. Apesar da complexidade e centralidade da questão, parece que a problemática ainda se mostra incipiente nas esferas que envolvem a biblioteca universitária no país, corroborando percepções de que a ordem histórica continua se sobrepondo a demandas da realidade contemporânea.

Entretanto, o problema das distâncias simbólicas - não apenas delimitadas por culturas diferentes, conforme visto acima - entre o universo cultural que orienta a biblioteca universitária e seus públicos diversificados, via de regra, é apresentado nos discursos da área como questão de gestão e aquisição de competências especiais e específicas, conforme o fragmento 2 :

Quando o usuário aprende a utilizar os serviços e os produtos de que a biblioteca dispõe, de maneira eficiente, poderá (sic) adquirir uma visão diferente do "mundo", analisar criticamente a realidade social e atuar como agente de mudanças sociais, ampliando seus conhecimentos culturais e profissionais $(\mathrm{O}$ uso do facebook para a 
divulgação dos serviços das bibliotecas universitárias federais do nordeste. 2016. ENANCIB).

A eficiência no uso dos recursos da biblioteca universitária é defendida como solução para as dificuldades de diálogo com o patrimônio infodocumental. Sendo eficiente, o usuário irá adquirir uma visão diferente e analisar a realidade social sendo capaz de atuar como agente de mudanças. A eficiência é conceito que, conforme Rothbard (2013, p. 584), "não tem significado independente da busca de resultados específicos". Assim, no discurso, o resultado a ser alcançado seria a transformação da forma de ver, analisar e atuar no mundo, o que pode se dar a partir da utilização de serviços e produtos da biblioteca. Para Rothbard (2013) o emprego do termo eficiência é errôneo seja para referir-se às instituições seja em referência a indivíduos. Segundo o autor, mesmo que um sujeito delimite fins individuais, e aja para alcançá-los, suas ações não serão eficientes, pois agir eficientemente implica um sujeito que possua um "conhecimento perfeito" tanto de tecnologias, ações, fenômenos e reações futuras, o que é inviável num mundo que tem a incerteza como condição de sua existência.

O discurso sobre a eficiência na esfera da biblioteca mostra, de certa forma, uma visão ingênua das implicações ligadas aos processos de significação, representando os referidos processos ligados ao protagonismo cultural (PERROTTI, 2017) como uma questão procedimental. Assim, deixa de lado o papel fundamental exercido pelos contextos culturais amplos e pelas experiências sígnicas, além da própria biblioteca, cuja natureza, processos e práticas culturais atuam sobre o diálogo entre sujeito e patrimônio infodocumental.

Nesses termos, a relação do sujeito com a biblioteca universitária e o patrimônio infodocumental que sistematiza não é passível de caracterização a partir do termo eficiente; é ação inscrita em processo de aprendizado, que se dá por meio de participação e prática significativas. É certo que o sujeito age tendo em vista determinados fins, ele aprende, torna-se mais proficiente em certos aspectos, contudo, em nossas relações com o mundo estamos em constantes possibilidades de aprendizado, nunca prontos, somos sempre seres inacabados. Com isso, a noção de resultados específicos inscrita no termo eficiência revela sua inadequação para problematizar a relação do sujeito com a biblioteca. Em se tratando de participação numa outra cultura científico-acadêmica - a métrica da eficiência é incapaz de contemplar apropriações e aprendizagens que se localizam na esfera de valores, resultantes de formação que 
extrapola o saber usar e aplicar convenientemente os recursos da biblioteca. Se o início de um processo pode ser delimitado por um objetivo os percursos nos transformam de modo não previamente fixado. Vale dizer que tomar o conceito de eficiência para discorrer sobre relações entre sujeitos e patrimônio infodocumental é incorrer em abordagens limitadas e limitantes de mecanização da vida. É recusar nossa característica humana, incerta e cambiante, assim como negar espaço a ações transformadoras a partir de reelaborações do patrimônio simbólico.

A ideia de eficiência no processo de construção de conhecimento é corroborada nas representações referentes à definição de competência em informação, como no fragmento 3:

\begin{abstract}
No que se refere à competência em informação, esta pode [ser] compreendida como um conjunto de conhecimentos, habilidades e conhecimentos acerca do universo informacional e seus processos, de forma a identificar suas necessidades informacionais, acessar, buscar, interpretar, utilizar e comunicar a informação de maneira ética. (Análise das práticas educacionais dos bibliotecários em bibliotecas universitárias com enfoque na educação de usuários e na competência em informação. 2016. ENANCIB).
\end{abstract}

Na perspectiva desse discurso, a relação do sujeito com o patrimônio simbólico é abordada a partir da noção de competência em informação, termo amplamente empregado na Ciência da Informação e Biblioteconomia no país, mas que, segundo Nascimento (2018), se dá sem a devida reflexão sobre seu sentido. Para o autor, há uma indefinição terminológica em torno da noção de competência em informação, a qual corresponde a um conjunto de habilidades técnicas, inscritas no domínio da localização e recuperação da informação, com vistas à adaptação dos sujeitos às lógicas da sociedade da informação.

Fondin (2005 ${ }^{41}$ apud NASCIMENTO, 2018) argumenta que a mecanização e automatização em torno do processamento de informações, com o aumento exponencial do desenvolvimento e emprego das TIC, contribui para intensificar abordagens mecanicistas sobre os atos informacionais, reduzindo-os a ações procedimentais, desconsiderando-se os processos de apropriação simbólica e de produção do conhecimento, que implicam questões individuais e contextuais. É nessa perspectiva que se inscreve a noção de competência em informação, conduzindo a representações

\footnotetext{
${ }^{41}$ FONDIN, H. La science de l'information ou le poids de l'histoire. Les enjeux de l'information et de la communication, Grenoble, v. 2005, n. 1, p. 35-54, 2005.
} 
em torno da relação do sujeito com a ordem simbólica que desconsideram a noção central que caracteriza o sujeito de palavra, sua experiência e singularidades quando do encontro com o patrimônio simbólico.

A estratégia discursiva vincula competência em informação a uma ética nas relações dos sujeitos com a informação, termo empregado para conferir poder ao discurso. A partir de Freitas (2001), com a palavra ética temos o emprego de um termo para situar o destinatário do discurso em um dado domínio de significação desejado que, nesse caso, seria algo bom, positivo e inquestionável: agir com ética.

No entanto, se compreendermos a ética como uma reflexão crítica destinada a tematizar critérios para o "viver juntos" num mundo partilhado por todos, as experiências de relação com o patrimônio infodocumental desenvolvidas a partir da perspectiva do puro treinamento "amesquinham o que há de fundamentalmente humano" no exercício dessa relação, comprometendo o caráter formador para viver no mundo (TROMBETTA; TROMBETTA, 2008). O princípio básico de formação que compreenda a ética não desconsidera a natureza do ser humano, suas singularidades e experiência, dimensões que não são efetivamente consideradas e operacionalizadas a partir do conceito de competência em informação. A competência é abordagem mecanicista, vinculada à eficiência, à medição de resultados a partir de padrões prédeterminados, aos quais escapam os processos de significação.

Em face das representações sinalizando perspectivas diversas, por vezes antagônicas, a exigência de parâmetros epistêmicos que ofereçam rumos à concepção de biblioteca universitária ganha maior relevância. Caracterizar a biblioteca universitária como dispositivo voltado à relação significativa dos sujeitos com o patrimônio infodocumental, privilegiando a ordem da produção de sentidos ou, por outro lado, como instância de gestão dedicada à promoção do uso competente da informação, tomada como bem de consumo, demonstra a existência de enfoques que não se equivalem.

A profundidade do problema implica definições que estão acima do exercício de práticas ou do puro emprego de terminologias. As palavras designam, representam, afetam o mundo, assim, não é indiferente denominar estudante ou cliente; competência ou saberes; memória ou informação. O debate engendra posições que definem e distinguem alguém que conhece e produz conhecimento e cultura de uma peça de engrenagem humana a alimentar uma entidade planetária produtora de bens de 
consumo, que parece possuir "vontade própria", independentemente dos seres humanos que a habitam.

\subsubsection{Mediação da informação}

Como temática, a relação mediação da informação e biblioteca universitária é recorrente e apresentada sob diferentes ângulos nos discursos da área. No fragmento a seguir, bibliotecas universitárias são caracterizadas como "espaços de mediação e produção de sentido, nos quais ocorre a articulação entre o produtor (autor) e o receptor (usuário)" (A biblioteca enquanto espaço-tempo de aprendizagens e de desenvolvimento de competências: o case de uma biblioteca do IFRS. 2016. SNBU).

Em outro, aparece o entendimento de mediação da informação como "a ligação entre o (enunciador) o prestador de um serviço ou seu agente e o destinatário ou usuário-alvo, objetivando que a comunicação entre eles gere novos saberes" (Atuação de bibliotecários em bibliotecas universitárias brasileiras e portuguesas: espaço de mediação custodial ou pós-custodial? 2015. ENANCIB).

No terceiro fragmento, está estabelecido que "no serviço de informação e referência, as bibliotecas universitárias efetivam a difusão do conhecimento através da mediação da informação" (Design thinking: contribuições para o serviço de referência em bibliotecas universitárias. 2019. ENANCIB).

E no quarto fragmento "o conceito de mediação da informação surge como fundamentação teórica de práticas já realizadas pelos bibliotecários" (Design thinking: contribuições para o serviço de referência em bibliotecas universitárias. 2019. ENANCIB).

$\mathrm{O}$ arco de abrangência de representações do termo mediação incorpora a diversidade conceitual e as contradições que marcam a noção e são apresentadas na literatura. A primeira abordagem ressalta a perspectiva da biblioteca universitária como espaço de mediação da informação e de produção de sentido, demarcando as figuras do produtor e do receptor (usuário). Este último, todavia, ocupa posição passiva nessa relação, um mero receptor. Assim, na dimensão discursiva não é representado como produtor de significados para a informação, pode vir a ocupar a posição de produtor, mas não a ocupa, não é tomado como tal, mas sim como alguém que recebe. Representação semelhante, que limita a ideia de mediação da informação às esferas 
individuais, está destacada no fragmento 2, que caracteriza a mediação como ligação entre enunciador e destinatário, sujeitos que ocupam posições determinadas por suas funções e papéis no processo comunicacional.

A questão, de um lado, vincula-se à problemática anteriormente abordada sobre o papel da biblioteca universitária ser definido a partir da transferência de sinais, inviabilizando a própria noção de relação, que implicaria contrapartidas de ambas as partes. De outro lado, se a recepção implica produção de sentidos, não compete ao domínio da Ciência da Informação perscrutar a subjetividade da recepção, portanto, da significação. A este campo do conhecimento competem interrogações sobre dispositivos de informação e cultura, discussões sobre em que medida são pensados e configurados para a expressão do desejo de conhecer dos sujeitos, dispondo de meios que o viabilizem. Portanto, diante de discursos da área como os acima apresentados centrados nos sujeitos -, indicamos ser preciso redirecionar enfoques para os dispositivos de informação e cultura, sobre os quais a área pode estabelecer proposições epistêmicas.

Estratégia discursiva semelhante aparece no fragmento 3 para evidenciar que a difusão do conhecimento se dá a partir da mediação, equiparando o significado das duas noções e remetendo à frágil compreensão de conhecimento, por não incluir sua dimensão processual.

A indicação, conforme fragmento 4 , que o conceito de mediação da informação surge como fundamentação teórica de práticas já realizadas pelos bibliotecários, coloca a noção em esfera nebulosa, face às diferentes nuances que implicam as práticas bibliotecárias, permitindo pressupor tratar-se de espécie de galvanização, tendo em vista conferir estatuto teórico a ações empíricas realizadas pela biblioteca universitária. Todavia, essa busca por dar sustentação e validação conceitual a práticas efetuadas no terreno, tende a retardar e minimizar esforços de compreensão de distinções centrais entre abordagens. Concepções que dizem respeito à participação afirmativa de sujeitos na cultura implicam não apenas nomeações novas, mas redefinição de paradigmas orientadores de práticas culturais. Sob essa ótica, nenhum dos discursos apresentados evidenciou tratamento da mediação enquanto episteme, mas somente como prática cultural. 


\subsubsection{O bibliotecário}

Os documentos analisados referem-se à temática da biblioteca universitária, sob o recorte profissional. No fragmento 1 a seguir, a ênfase refere-se a traços subjetivos:

[...] o profissional da informação deve possuir além de habilidades específicas, qualidades interpessoais (paciência, humildade, simpatia, criatividade, confiança entre outras) que deixem o usuário à vontade para expor suas dúvidas e questionamentos (Clube de leitura da BCE: relato de uma ação cultural na Biblioteca Central de Brasília (BCE/UnB). 2018. SNBU).

No fragmento 2 a ênfase está articulada a partir das TIC:

[...] o avanço acelerado das Tecnologias de Informação e Comunicação (TICs) continua exigindo mudanças constantes de comportamento do profissional da informação, para que seja possível acompanhar a evolução de um mundo interligado por apenas um clique (Relato da revitalização de uma biblioteca universitária. 2016. SNBU).

Aspecto também salientado no fragmento 3, ao indicar que o bibliotecário

ao longo do tempo foi se transformando de um profissional tecnicista em gerenciador da informação, mudando a ideia de um profissional preso a bibliotecas e a seus livros dando lugar a novos campos de atuação, a novas áreas de conhecimento (Bibliotecário e a mediação da informação: serviços de referência do presencial ao virtual.2018. SNBU).

O quarto fragmento acrescenta que

O contexto da sociedade conectada fez surgir novos modelos de atuação do bibliotecário como mediador da informação. [...]. Com essa nova realidade emerge um novo perfil profissional para atender as necessidades, tanto institucionais como as advindas do contexto externo; este profissional é encontrado na literatura com a denominação: o bibliotecário 2.0 (Competência em informação digital: o ponto de vista dos bibliotecários gestores das bibliotecas universitárias da associação catarinense das fundações educacionais. 2016. ENANCIB).

No fragmento 1, o perfil do bibliotecário, ali denominado profissional da informação, é caracterizado com base em atributos pessoais; representa alguém que 
dependerá de certos atributos (saberes e valores individuais) para o exercício de suas atividades. Além de travar relações com informações, é presumido que se relacione com outros indivíduos, devendo possuir habilidades para tanto. Essa representação do bibliotecário, a partir de um circuito marcado por inter-relações entre sujeitos e com a ordem simbólica destoa de grande parte dos discursos analisados, evidenciando um profissional que entra em dinâmicas de mediação cultural.

A representação da figura do bibliotecário - no fragmento 2 - se dá a partir das TIC, do acompanhamento e incorporação dessas ferramentas, tomadas como condição definidora da existência do profissional da informação, face às exigências de sintonia com a evolução de um mundo interligado e, portanto, para que ele mesmo evolua. Por meio de recurso que delimita dimensão cronológica - ao longo do tempo - o fragmento 3 apresenta uma evolução na profissão do bibliotecário, outrora profissional tecnicista, atualmente um gerenciador da informação, não mais preso a bibliotecas e livros, mas atuante em novos campos, embora não explicitados. O discurso representa o gerenciador da informação como um profissional inscrito no novo, contrapondo a imagem do profissional que atua com livros e bibliotecas como tecnicista situado, a partir da linha cronológica proposta, num tempo antigo.

$\mathrm{Na}$ mesma perspectiva discursiva, o fragmento 4 evidencia uma sociedade conectada que fez surgir novos modelos de atuação para o bibliotecário enquanto mediador da informação. A nova realidade é representada como categoria que exige um novo perfil profissional, caracterizado no discurso a partir do termo bibliotecário 2.0, em referência à Web 2.0. O profissional que atua como mediador da informação é definido em termos tecnológicos, seu fazer profissional é representado a partir da mediatização das relações entre sujeitos e universo simbólico, não havendo alusão às inter-relações entre sujeitos e o patrimônio infodocumental.

Num contexto discursivo em que as relações com o patrimônio infodocumental são, em grande medida, delimitadas por um viés instrumental, os discursos sobre o bibliotecário são desenvolvidos na mesma perspectiva. Em meio a textos que abordam diretamente um dispositivo inscrito no contexto educativo, o fazer do bibliotecário é caracterizado em função das TIC, numa abordagem tecnológica que desloca o foco das interações simbólicas com o patrimônio infodocumental. Num circuito em que a função sociocultural e educativa da biblioteca universitária não é de fato representada, a formação do bibliotecário não compreende o significado social e político de sua atuação. Sua função como mediador cultural é definida em termos do domínio de 
ferramentas para o envio de informações, em discursos aos quais escapa o significado e o papel do bibliotecário como figura central dos dispositivos, processos e práticas de mediação cultural.

\title{
5.2.1.11 Instituições de Ensino Superior
}

Os discursos tematizando as bibliotecas universitárias recobriram representações que tratam das IES, desde seu papel no âmbito educacional e social mais amplo até perspectivas ligadas a mercado e empregabilidade.

O primeiro fragmento considera que "além da qualificação profissional composta pelo 'domínio das ferramentas investigativas', é inerente ao ensino superior 'o desenvolvimento da formação cultural das novas gerações, que possa situá-las no contexto mais amplo da vida social"”. (Biblioteca universitária e formação cultural. 2019. ENANCIB).

Em perspectiva paralela, o fragmento 2 indica que:

\begin{abstract}
A universidade tem a missão não apenas de possibilitar aos alunos a obtenção de um diploma, um emprego ou remuneração satisfatória, ela é também capaz de produzir novos conhecimentos para serem aplicados à realidade social. Sua função se aplica a toda a sociedade, em todos os níveis sociais, para que haja inclusão exercendo tanto uma função social que realiza e exprime de modo determinado a sociedade de que faz parte. Ela não é uma realidade separada e, sim, uma expressão historicamente determinada de uma sociedade (Biblioteca universitária: sua função social enquanto lugar de memória. 2016. SNBU).
\end{abstract}

As abordagens acima destacam-se por compreenderem que a educação superior não se reduz ao atendimento de demandas do mercado de trabalho. Voltada a uma formação cultural, é representada como condição para que os sujeitos se situem num contexto mais amplo da vida social (fragmento 1), caracterizando-se como instância não limitada à formação voltada a uma cultura específica e especializada, restritamente vinculada a um campo de atuação profissional.

A estratégia discursiva assemelha-se a do fragmento 2, vinculando a universidade à produção de conhecimentos para serem aplicados à realidade social, e opondo-se, assim, à função exclusiva de formar o sujeito para que obtenha um emprego com remuneração satisfatória. O discurso representa a universidade como instituição 
social, uma "prática social fundada no reconhecimento público de sua legitimidade e de suas atribuições, num princípio de diferenciação, que lhe confere autonomia perante outras instituições sociais" (CHAUI, 2003).

Os demais discursos seguem em outra direção. O fragmento 3 enfatiza que:

As organizações na atualidade precisam investir em inovação, caso queiram permanecer fortemente ativas e influentes no segmento de mercado em que atuam, sendo que a inovação deve estar presente tanto em seus processos e estratégias quanto em seus serviços. Assim, considera-se a Universidade como uma organização cuja missão é, inclusive, a de propiciar a apreensão e geração de novos conhecimentos (Design thinking: contribuições para o serviço de referência em bibliotecas universitárias. 2019. ENANCIB).

Além disso, o fragmento 4 indica que:

[...] na virada do milênio, o padrão competitivo capitalista demanda das instituições de ensino superior a capacidade de se manterem constantemente atualizadas, principalmente em razão do caráter interativo e localizado do aprendizado e da inovação. Neste sentido, as universidades são convidadas a repensar, continuamente, suas políticas, ações e espaços, tendo em vista sua função de promover o desenvolvimento econômico e social, por meio de uma formação orientada para a inovação e o empreendedorismo (Ferramenta de gestão SWOT aplicada a biblioteca universitária da UFPI. 2019. ENANCIB).

A IES é caracterizada como organização, nos discursos que alinham a educação superior ao atendimento exclusivo a demandas do mercado. Assim, no fragmento 3, a universidade é uma organização que precisa investir em inovação para permanecer fortemente ativa e influente no segmento de mercado em que atua, enquanto no fragmento 4, é representada como promotora de formação orientada para a inovação e o empreendedorismo. Enquanto organização, a universidade é representada a partir da instrumentalidade, cujos princípios são regidos por referenciais e práticas com base em ideias de eficácia e sucesso no emprego de meios para alcançar objetivos particulares que a definem, sendo orientada pelos conceitos de planejamento, previsão e êxito (CHAUI, 2003). Nesses termos, não compete à universidade discussões ou questionamentos sobre sua função e existência, cabendo-lhe inovar para permanecer ativa no segmento de mercado que ocupa. 
Para Thrift (2005 42 apud FONTENELLE, 2012) a academia vem sendo desenvolvida sob a orientação dos negócios. Suas disciplinas sendo absorvidas pelo mercado e o capitalismo tornando-se, assim, mais "inteligente", por meio do emprego de mão de obra altamente qualificada. Com isso, o conhecimento produzido no mundo acadêmico vai se moldando à imagem e semelhança do mundo dos negócios, ou seja, de forma rápida, voltada ao atendimento de demandas de natureza prática do saber, tendo em vista promover o desenvolvimento econômico tal qual indicado no fragmento 4. Caracterizar as IES como organizações a serem geridas sob lógicas do mercado, definindo sua produção à imagem e semelhança deste, é conceber a formação de pessoas e a produção do conhecimento do mesmo modo que se concebe produção no sentido capitalista, subvertendo princípios que orientam a formação superior para o cuidado do mundo.

\subsubsection{O lugar da biblioteca universitária na educação à distância}

Os discursos enfatizam a importância da biblioteca universitária na educação à distância $(\mathrm{EaD})$, salientando seu papel de apoio ao estudo, conforme apresentado no primeiro fragmento:

[..] a biblioteca universitária é um instrumento fundamental de apoio à pesquisa, e a ela, especificamente compete fornecer informações em níveis compatíveis com as necessidades dos usuários como apoio imprescindível às atividades de ensino, pesquisa e extensão [...]. Não sendo diferente, portanto, seu papel no Ensino à distância (O papel da biblioteca virtual na mediação do ensino à distância. 2018. SNBU).

A segunda perspectiva considera que

Ao contrário do que acontece com os alunos dos cursos presenciais, os alunos da $\mathrm{EaD}$, na maioria das vezes, ainda não possuem acervos sistematicamente organizados, a eles disponibilizados, como também não contam com a presença de profissionais para atendimento no ambiente virtual ou mesmo nas Bibliotecas dos Polos (Bibliotecas universitárias e a gestão da informação para o usuário das bibliotecas dos polos da educação a distância. 2018. ENANCIB).

\footnotetext{
${ }^{42}$ THRIFT, N. Knowing capitalism. London: Sage, 2005.
} 
Os fragmentos assinalam, de um lado, a importância da biblioteca na EaD e, de outro, sua precariedade naquele contexto. Assim, se o fragmento 1 indica que a ela compete fornecer informações, o segundo argumenta que essa dimensão não é atendida a contento no contexto brasileiro ${ }^{43}$. Os discursos representam a biblioteca universitária, no contexto virtual, de modo semelhante à ótica prevalente no modelo de difusão informacional que orienta concepções vigentes, ou seja, instância complementar de distribuição de conteúdos de ensino. Não há evidências, pelos discursos apresentados, de problematizações indispensáveis acerca da constituição de bibliotecas virtuais, igualmente complexas, em se tratando da inserção dos estudantes na cultura científicoacadêmica.

O quadro é alarmante, considerando-se que a ênfase na educação a distância, como alternativa à precariedade de acesso ao ensino superior, tenderá a colocar as bibliotecas, como (grandes) repositórios remotos de oferta informacional. Suprir carências de informação, todavia, não equivale a suprir a carência da experiência cultural, questão a ser refletida por tratar-se de elemento-chave da formação de estudantes universitários. Nesse caso, de acordo com as representações coletadas, tais implicações não foram pautadas nem pela área acadêmica nem pelo campo profissional. Em síntese, o que ressalta é a visão de que a existência da biblioteca - enquanto espaço físico concreto - pode ser automaticamente assimilada pela biblioteca virtual, bastando, para isso, a manutenção de repositórios online. O debate da questão é central porque tange a esfera da formação de mentalidades, e a superação dessa abordagem, certamente, está ligada ao estabelecimento de novos referenciais conceituais e metodológicos, que atentem para a singularidade da biblioteca universitária virtual, e que explicitem o limite de concebê-la como coleção organizada.

Nessa perspectiva, a ênfase disposta no fragmento 2 em relação à ausência de profissionais para atendimento aos estudantes no ambiente virtual, é aspecto que, de um lado, traduz a constante necessidade de mediações explícitas, mas, por outro, somente desloca para o circuito virtual os mesmos elementos e lógicas da esfera presencial.

De fato, há um grande terreno a ser explorado nessa direção, sobretudo em nosso país, e os indicativos presentes nos discursos têm seu valor especialmente na denúncia

\footnotetext{
${ }^{43}$ Neste ponto é importante destacar que o fragmento 2 é de texto que constitui um recorte de pesquisa de doutorado e de mestrado, cujo objetivo foi descrever percepções e usos de bibliotecas por graduandos do ensino a distância.
} 
de uma situação a ser colocada, com urgência, na agenda científica da área, dadas as soluções exclusivamente adaptativas ora em causa.

\subsubsection{O espaço físico da biblioteca universitária}

A materialidade da biblioteca em contexto universitário é o aspecto privilegiado no fragmento 1, que salienta o valor do seu espaço aos atos de construção de conhecimento:

[...] as universidades estão gradualmente tornando-se conscientes da importância de instalações atraentes para a biblioteca. Este fato tem gerado constantes mudanças no que diz respeito às funções e atividades das bibliotecas universitárias ( $\mathrm{O}$ futuro da biblioteca universitária: tendências da revisão de literatura. 2017. ENANCIB).

O fragmento 2 afirma que "a professora Marisa Midori [...] reforça a teoria das bibliotecas como ambientes de sociabilidade, um local onde as pessoas se reúnem para trocar ideias e defende ainda a importância sobre a existência das bibliotecas físicas na atualidade" (Projeto biblioteca viva: revendo os conceitos e renovando os espaços. 2018. SNBU).

No terceiro fragmento indica-se que

Powell (2002) $)^{44}$ sinaliza a tendência dos designers em bibliotecas para o século XXI, no sentido de criar ambientes que facilitem a aprendizagem, considerando mais especificamente a aprendizagem centrada no aluno e não mais no ensino. Castro Filho $(2011)^{45}[\ldots]$ apresenta o modelo europeu dos Centros de Recursos para el Aprendizaje y la Investigación - CRAIs. [como] entidade física, que não só armazena documentos e equipamentos, mas se constitui como um espaço atrativo e de socialização, considerando que, com a grande expansão das bibliotecas virtuais, a biblioteca física se mantém como ponto focal e natural para a aprendizagem (Relato da revitalização de uma biblioteca universitária. 2016. SNBU).

\footnotetext{
${ }^{44}$ Referência citada, conforme consta no documento: POWELL, M. Designing library space to facilitate learning: a review of the UK higher education sector. Libri, v. 52, p. 110 - 120, 2002.

45 Referência citada, conforme consta no documento: CASTRO FILHO, C. M.; VERGUEIRO, W. Convergências e divergências do modelo europeu do Centro de Recursos para el Aprendizaje y la Investigacion (CRAI) em relação às bibliotecas universitárias brasileiras. Bibl. Univ., Belo Horizonte, v.1, n.1, p. 31- 40, jan./jun. 2011.
} 
Os discursos são unânimes na indicação da importância da qualidade do espaço físico da biblioteca universitária. Instalações atraentes são preconizadas como essenciais e viabilizadoras de novas funções e atividades da biblioteca, assim como ambiente de sociabilidade, lugar para troca de ideias. Nessa perspectiva, o fragmento 3, sugere que a biblioteca seja tomada como um centro de recursos para aprendizagem e pesquisa e um local de socialização, ultrapassando perspectivas restritas ao armazenamento de documentos e equipamentos. É indicado que o termo centro de recursos para aprendizagem e pesquisa está alinhado às perspectivas do século XXI, ultrapassando modelos de ambientes físicos que têm como função só armazenar documentos e equipamentos, o que leva o leitor a vincular essa função à noção de biblioteca. A sigla CRAIs busca conferir um novo ambiente e sentido à biblioteca universitária, comportando as dimensões da aprendizagem e da socialização dos sujeitos.

O fragmento 3 foi extraído de texto que discorre sobre a experiência de remodelagem de uma biblioteca universitária e afirma que nesse processo se deu a "readequação do espaço físico" e a criação de "sala multiuso". Essa biblioteca universitária, reformulada em perspectiva alinhada com a de um centro de recursos para aprendizagem e pesquisa, realizou as seguintes atividades, conforme apresentado no texto: "artesanato solidário", "exposição de trabalhos e atividades lúdicas [disponibilizando] a área de exposições para as crianças que frequentam a creche e préescola", "workshop [para a graduação] a fim de capacitá-los para a participação de processos seletivos [de emprego]".

Desta forma, embora os discursos argumentem que o espaço da biblioteca é de aprendizagem e socialização, ao não descreverem mais claramente o significado desses conceitos no âmbito da biblioteca universitária, eles permitem a alimentação de práticas culturais nem sempre pertinentes, ou mesmo descontextualizadas, ao ambiente da biblioteca no ensino superior.

Assim, as relações entre sujeitos, articuladas a partir do patrimônio infodocumental - pressuposto do princípio que orienta os dispositivos de mediação cultural - não são efetivamente consideradas, como apontado no terceiro fragmento. Pelo contrário, ele nos informa que essa biblioteca universitária, cujo ambiente foi remodelado como centro para aprendizagem e pesquisa, ao invés das atividades que lhe seriam inerentes e apropriadas, conforme suas novas configurações, acaba realizando 
atividades de artesanato e workshops para que estudantes se insiram no mercado de trabalho.

Como espaço de socialização, faltou, segundo o que se apreende dos discursos, clareza sobre a especificidade da biblioteca universitária enquanto dispositivo de socialização do patrimônio infodocumental e de educação dos estudantes para participação na cultura científico-acadêmica, mais especificamente, na cultura do pensamento acadêmico.

Nesse sentido, a relação com o conhecimento e o lugar do patrimônio infodocumental na formação do estudante não são evidenciados nesses discursos sobre o espaço físico da biblioteca. Por meio da sua materialidade, a biblioteca universitária viabiliza socialização, trocas culturais, aprendizagens e processos de produção do conhecimento, já que a dimensão física engendra possibilidades que tangenciam esferas da imaterialidade, as quais envolvem informação, conhecimento e cultura científicoacadêmica.

\subsubsection{Tramando os pontos da rede de sentidos: síntese das representações de biblioteca universitária}

Nesta seção apresentamos a rede de sentidos em torno da biblioteca universitária que emerge dos 45 documentos tratados, referentes aos últimos 5 anos de publicações do ENANCIB e SNBU, incluindo aqueles cujos fragmentos não constam nas seções anteriores.

O dito e o pressuposto (não-dito) revelam como a biblioteca universitária vem sendo desenvolvida no Brasil em suas dimensões técnica, semiológica e pragmática. Buscamos, a seguir, expor pontos centrais que, em nossa compreensão, constituem grande parte da rede de sentidos articulada pelos distintos textos, objeto da pesquisa. Nessa perspectiva, optamos por destacar em itálico algumas palavras, evidenciando como aparecem nos textos analisados. Com isso, esperamos conferir ao leitor certa condição de acesso aos sentidos dos textos para além da análise da pesquisadora.

Identificamos ser recorrente em diferentes discursos o emprego de termos advindos de outros campos do conhecimento para indicar objetos de natureza distinta, o que parece configurar uma assimilação acrítica. Assim, a universidade foi exposta como empresa, na qual a biblioteca se inscreve e é voltada às mediações da informação. A mediação da informação também surge como recurso à adaptação aos fluxos 
informacionais, assim como os processos dialógicos foram apontados como importantes junto aos clientes das bibliotecas.

Não raro, em sua linearidade alguns textos revelaram certa dissonância entre seus conteúdos, o que traz como indício terem sido elaborados a partir de referenciais que não foram efetivamente refletidos e considerados face ao objeto biblioteca universitária.

Depreendemos a partir de parcela considerável dos textos que a relação do estudante com a informação científica e o conhecimento acadêmico não é objeto de problematização na área. Além disso, a biblioteca universitária - que na perspectiva da presente pesquisa é abordada enquanto categoria essencial dos processos em torno da apropriação do patrimônio infodocumental -, é alvo de discussões voltadas à sua adaptação à hiperaceleração dos fluxos informacionais, assim como à sua transposição para o digital. Contudo, isso se dá sem problematizações da própria noção de biblioteca - em especial na modalidade universitária, portanto educativa. Identificamos ser recorrente a busca por atribuir um sentido à biblioteca universitária na atualidade, mas isso ocorre em concordância com lógicas sociais que não colocam em questão o valor da informação, exceto como insumo (mercadoria), desconsiderando sua dimensão simbólica intrínseca aos atos de significação e, portanto, inerente às complexas dinâmicas do conhecimento.

Certos discursos apresentam um cenário marcado por profundas transformações dos fluxos informacionais com o advento das novas $T I C$, no contexto da Internet. É indicado um quadro irreversível no qual a biblioteca universitária estaria inscrita: o da sociedade da informação, justificando, portanto, ter que se adaptar para responder às demandas de um mercado informacional e tecnológico cada vez mais exigente.

Há problematizações em torno da importância de que a biblioteca esteja também presente na World Wide Web, seja em termos de trocas com os públicos, seja em termos de sistematização e disponibilização de informações. Nessa perspectiva, os sentidos de grande parte dos textos revelam a biblioteca universitária como dispositivo com função eminentemente informacional, voltada à sistematização e disponibilização de dados indispensáveis ao atendimento dos quadros universitários. Ao abordarem as TIC, muitos trazem a imagem de uma biblioteca universitária a reboque das tecnologias, construindo representações da sua função em diálogo com os fluxos informacionais contemporâneos tal como vêm sendo consolidados. 
É consideravelmente presente a preocupação com o papel da biblioteca universitária na atualidade e transformações são apresentadas como essenciais à sua manutenção e desenvolvimento. Entretanto, a discussão se dá em termos de como incorporar em seus fazeres o uso de certas TIC que melhorem a qualidade dos serviços e produtos informacionais oferecidos. As falas, em grande medida, revelam uma lógica que pressupõe acompanhar e incorporar o desenvolvimento dessas tecnologias, desconsiderando problematizações face às relações dos estudantes com o patrimônio infodocumental e à função educativa que integra o princípio da biblioteca universitária.

Nesses termos, vimos indícios de uma preocupação em refletir sobre o uso de mídias sociais digitais. Um dos textos abordou as mídias sociais como ferramentas para promover socialização e compartilhamento de conhecimentos, indicando a pertinência de que o bibliotecário atue mediando informações nesse circuito. Além disso, outro texto questionou o uso exclusivo de mídias sociais para divulgação de produtos e serviços, apresentando a importância de que possibilidades de interação, práticas de leitura e escrita fossem exploradas. Contudo, discussões que tomam esse circuito como espaço de inter-relações são exceção no corpus analítico, pois a grande maioria dos textos explora o uso das mídias sociais exclusivamente para comunicação de produtos e serviços oferecidos pelas bibliotecas universitárias. Ferramentas como Facebook, Blog, Twitter, etc. foram abordadas como formas de enviar informações ao público. O foco de grande parte das discussões foram as postagens, exclusivamente o envio de informações pela biblioteca, e não as inter-relações, o que nos leva a indicar que, em grande medida, tais ferramentas estão sendo pensadas no contexto das bibliotecas universitárias sob um modelo comunicacional linear, de envio de informações a um receptor, engrossando a cadeia do distributivismo informacional.

Por sua vez, cabe destacar que se fez inexistente qualquer tipo de abordagem que considerasse tais ferramentas como propriedade de empresas que atuam na configuração de fluxos informacionais contemporâneos sob as lógicas do capitalismo global. Com isso, queremos destacar a ausência de problematização ou de reflexão crítica sobre as próprias ferramentas digitais, tomadas como objeto de significação. A constatação permite considerar a existência de uma abordagem que toma os estudantes, na esfera das bibliotecas, como consumidores de informação; ideia compatível com noções em uso nas mídias sociais, já que grande parte deses dispositivos comunicacionais é forjado a partir da perspectiva do consumo. Nesse contexto, face à ausência de distinção, prevalecem dinâmicas acríticas. 
Não vimos nos textos considerações sobre necessidades latentes ou desejos dos sujeitos em termos de informações. $\mathrm{O}$ uso predominante do termo necessidade leva a indicarmos que a perspectiva lançada sobre a informação é, sobremaneira, a da utilidade; trata-se, assim, de um produto que serve para algo que já está claramente delimitado desde o princípio. Grande parte dos discursos não considera que muitos não sabem o que querem ou precisam saber e, da mesma forma, deixam à margem a esfera do desejo de conhecer. Apenas um texto trouxe essa problemática, ao indicar que estudantes em início de curso de pós-graduação têm certa dificuldade em delimitar e expor suas necessidades de informação face ao próprio campo de estudo. Nessa perspectiva predominante, a informação é abordada a partir de discursos que desconsideram desejos, curiosidades e necessidades latentes dos estudantes, e que, por sua vez, estão diretamente implicados em processos de inter-relação de sujeitos epistêmicos com a ordem simbólica.

O recorte proposto buscou incorporar textos que trouxessem diretamente abordagens sobre a biblioteca universitária em relação ao seu público, eminentemente composto por estudantes. Vimos que, via de regra, estes são tomados a partir do termo usuário; poucos foram os discursos pautados na noção de estudante, sendo que em alguns sobressaíram os termos cliente e consumidor, remetendo a biblioteca à esfera de consumo simbólico, noções que se identificam de imediato ao modelo de mercado. Torna-se forçoso atentar para o uso recorrente do termo usuário em detrimento da denominação estudante, acabando por reforçar representações utilitaristas tanto da informação como da biblioteca universitária. Esse aspecto contribui para confirmar a prevalência de abordagem que não inclui o processo de formação implicado na educação superior, o qual demanda aprendizagens não só de conteúdos intelectuais, mas também de formas de se relacionar com estes, enquanto questão que afeta o modelo de biblioteca em todos os níveis e contextos educativos.

Em face disso, se a figura do usuário assume importância nos discursos que indicam como função da biblioteca atendê-lo em suas necessidades explícitas, sobressai, no entanto, um paradigma difusionista que desconsidera o sujeito de palavra que, em relações com a ordem simbólica, produz significados.

São recorrentes os discursos sobre a competência informacional, sinalizando para a importância de que esses usuários consigam utilizar a biblioteca e seus recursos informacionais, que saibam acessar, buscar, selecionar, usar e comunicar informações de modo competente e ético. Assim, a discussão se inscreve na problematização de 
grandes fluxos informacionais e a consequente necessidade de que os usuários tenham de se situar frente a eles, contudo, via de regra, deixando de lado a esfera da significação. Assim, os discursos sobre biblioteca universitária, embora apontem a relação de um sujeito, o usuário, com a ordem simbólica, a informação, desconsideram o conhecimento acadêmico, bem como a noção de que o estudante é um sujeito de conhecimento. Prepondera, então, um modelo comunicacional linear de envio de informações - como transmissão de sinais - de um polo emissor a um receptor.

A importância da cultura na formação dos sujeitos foi discutida nos textos $\operatorname{lidos}^{46}$ : dois deles apontam ser fundamental que o estudante tenha contato com referências culturais mais abrangentes, que extrapolem as demandas do curso de graduação, e um terceiro indica a noção de formação cultural para refletir sobre o papel da biblioteca universitária. Além disso, um dos textos abordou a biblioteca universitária a partir de perspectiva histórica, considerando a educação superior e salientando que esse dispositivo passou a se voltar à formação de mão de obra qualificada, deixando de lado a formação cultural e social mais ampla. A baixa representatividade da discussão é indicativa de que a biblioteca universitária é majoritariamente representada na área como um dispositivo voltado, exclusivamente, ao atendimento das demandas informacionais diretamente atreladas aos cursos.

O patrimônio infodocumental que a biblioteca universitária disponibiliza foi problematizado por um único texto que, ao discutir políticas de informação, indicou a importância de que a transformação de perfis da comunidade acadêmica, assim como a falta de cultura de biblioteca que marca nosso país, sejam consideradas em abordagens que busquem revisar o seu papel na educação superior, o que inclui rever a natureza e o caráter de seus acervos.

De outro lado, o conceito de interculturalidade consta em um dos textos lidos, que discutiu a relação de estudantes indígenas e quilombolas com a biblioteca universitária, afirmando a importância de que a universidade incorpore a noção de alteridade em suas esferas de abrangência. Portanto, um único texto trouxe o conceito de interculturalidade para discutir não só as diferenças, mas também como estas inscrevem-se num cenário de desigualdades que cria barreiras a relações desses sujeitos

\footnotetext{
${ }^{46}$ Além dos textos mencionados, identificamos mais um, entretanto, tivemos acesso somente ao seu resumo e, por isso, o mesmo não foi considerado em nossa análise. Segue a referência do texto que, embora pertinente, não foi objeto de AD: FERNANDES, Patrícia Verônica N. Dias; SUELY, Santana; RIBEIRO, Rejane Maria Rosa. Ação cultural em bibliotecas universitárias: diálogo entre educação formal e não formal. In: SEMINÁRIO NACIONAL DE BIBLIOTECAS UNIVERSITÁRIAS, 20., 2018, Salvador. Anais... Salvador: UFBA, 2018.
} 
com a informação científica e o conhecimento acadêmico em perspectiva de trocas mútuas, de apropriação simbólica. A escassez de discursos nessa direção, considerando aspectos socioculturais do meio, leva a entender que a área, em grande medida, delineia representações homogeneizantes "abstratas" dos públicos da educação superior e, consequentemente, da biblioteca universitária mesmo num contexto como o nosso, marcado por diferenças e desigualdades, e pela ampliação do acesso à educação superior, tomada como ponto de chegada e não como o início de um novo e complexo processo de formação.

Cabe ainda indicar a existência de discussões em torno da garantia do acesso à informação a pessoas com deficiências físicas, evidenciando o aumento desse público na educação superior assim como a importância de que a biblioteca universitária lhes garanta o direito de acesso à informação.

O conceito de mediação é apresentado como questão que ultrapassa o ato de transferir informação. Em alguns textos surge vinculado ao conceito de apropriação. Todavia, grande parcela dos textos não dispensa à noção o aprofundamento devido, empregando-a apenas como um recurso para qualificar ações de transferência de informação. Assim, no mesmo texto em que a mediação é abordada como ação que propicia a apropriação da informação, temos a figura do usuário, alguém que não é considerado em suas singularidades e que precisa ser competente para conseguir acessar e usar a ordem simbólica que lhe é externa.

A figura do bibliotecário está presente em alguns discursos. O profissional é apresentado seja para indicar seu papel como mediador, gestor da informação e do conhecimento, seja problematizando a urgência de que desenvolva competências informacionais face ao contexto contemporâneo, indicando a pertinência da formação continuada. A tônica de muitos discursos em torno do bibliotecário inscreve-se na importância do domínio de ferramentas tecnológicas, tendo em vista o desenvolvimento de capacidades para acompanhar as transformações dos fluxos informacionais e ter relevância garantida na atualidade.

Embora certos textos representem o bibliotecário como um mediador, a ação de mediar não é alvo de interrogações em relação ao seu significado na ordem cultural. Apenas constata-se a importância dessa ação que se diz já ser efetuada - ou que pode ser efetuada - por esse profissional, mas esse fazer não é efetivamente problematizado. Quando se discorre sobre mediação a formação do bibliotecário não surge como questão, contudo, quando as TIC são discutidas a formação desse profissional é 
interrogada. Temos, então, um indício da naturalização de saberes e fazeres em torno da mediação cultural, assim como da simplificação desta noção teórica essencial ao desenvolvimento de metodologias concretas que, no âmbito da Ciência da Informação e Biblioteconomia, mostram-se centrais, tendo em vista a necessidade de abordagens e ações que não se limitem à distribuição qualificada de informações.

O espaço da biblioteca também foi problematizado em discursos que indicam sua relevância a partir de perspectivas diversas, alinhadas à noção de biblioteca como terceiro lugar (SERVET, 2010), que preconiza ações de sociabilidade dentre as funções a serem assumidas por esse dispositivo na contemporaneidade. Contudo, em meio aos novos papéis propostos para a biblioteca universitária perde-se de vista o principal motivo de sua existência, ou seja, a relação dos sujeitos com o patrimônio infodocumental implicado na educação superior.

As discussões em torno da educação superior remetem a distintas formas de representar o estudante: alguém sendo formado exclusivamente para o mercado de trabalho, um cliente dessa empresa que é a IES, mas também, um cidadão, sujeito que irá atuar no mundo. Essas representações indicam perspectivas muito diversificadas sobre os públicos da biblioteca universitária, podendo impactar nas ações desenvolvidas junto a eles.

Foram poucas as discussões que abordaram relações da biblioteca com a sala de aula, indício de uma ideia de biblioteca universitária com função exclusivamente informativa, assim como da fratura na relação biblioteca e educação em nossa sociedade. Ao assumirmos a existência de um problema no âmbito das relações do estudante com a ordem simbólica implicada na educação superior, consideramos pertinente interrogar qual o lugar da biblioteca universitária na formação dos sujeitos, buscando ultrapassar a perspectiva da exclusiva oferta de informações para atendimento das demandas dos cursos. Na medida em que o acesso, por si só, não garante relações críticas e criativas com a ordem simbólica, abordar questões implicadas nas dinâmicas entre biblioteca e sala de aula - numa perspectiva que ultrapasse a simples aquisição de bibliografia indicada pelos cursos -, parece-nos essencial.

Uma parcela considerável das discussões revela que a Biblioteconomia e a Ciência da Informação brasileiras priorizam o debate da biblioteca universitária em dimensão instrumental e procedimental, sem interrogações sobre seu caráter essencial, tema próprio da área. 
A questão sobre o que é uma biblioteca universitária no contexto do século XXI vem sendo tratada, de modo mais amplo pela área, em termos técnicos de incorporação de TIC, seja para sua adequação a fluxos informacionais mais amplos, ou para o exercício, no meio virtual, de práticas que a biblioteca já exerce tradicionalmente no âmbito físico presencial.

Grande parcela dos textos revela que a biblioteca universitária vem sendo representada a reboque dos fluxos informacionais inscritos nas lógicas do capitalismo global, o que se constata a partir do que não é dito sobre: o estudante; a biblioteca como instância de diálogo com o patrimônio infodocumental e de inter-relação entre sujeitos; o conhecimento; a inserção dos estudantes em paradigma informacional e cultural novo e suas recorrências no processo de constituição da memória cultural. Nesse contexto, a biblioteca não aparece como objeto da formação universitária e, assim, seus profissionais não dispõem de referências para pensar sua problemática históricocultural.

Em face disso, a biblioteca universitária mantém-se sob um paradigma difusionista, tal qual ocorrera na modernidade. Em grande medida as representações delineiam, de um lado, um dispositivo orientado e organizado para distribuição eficaz e eficiente de signos; de outro, para aprendizagens que visam o acesso e o uso competente das informações pelos seus públicos. Portanto, como pressuposto (o não-dito), o processo do conhecimento é tomado como a assimilação de informações e o saber usálas com competência a partir de lógicas previamente determinadas.

No entanto, as alterações operadas na contemporaneidade nos quadros da informação em específico, e na ordem sociocultural de modo geral, reclamam por novos paradigmas que permitam pensar e desenvolver a biblioteca universitária enquanto dispositivo capaz de contribuir para a democracia cultural, por meio da formação dos sujeitos como criadores de conhecimento e cultura. É fundamental que às discussões sobre a biblioteca universitária somem-se discussões de cunho teórico sobre seus públicos, objetos e funções como caminho à emergência de outras representações de estudante, de patrimônio simbólico, de bibliotecário, de educação superior, de relação com a ordem simbólica e de IES, essenciais ao estabelecimento de proposições epistêmicas para a representação de uma biblioteca universitária efetivamente contemporânea.

Enfim, um conceito de biblioteca universitária que contribua para a formação de sujeitos capazes de captarem a densidade do momento histórico em que se situam, a 
partir de relações críticas e afirmativas com o patrimônio infodocumental, organizado e disponibilizado por uma biblioteca que seja um lugar de conhecimento. Portanto, um dispositivo que promova relações de significação entre sujeitos e patrimônio simbólico. Nesse sentido, mediação cultural é conceito-chave e paradigmático para a biblioteca universitária, tendo em vista seu valor como episteme que permite a abordagem do processo comunicacional enquanto produção de sentidos, envolvendo sujeitos, seus contextos, culturas - referências que internalizamos - e patrimônio infodocumental. 


\title{
6 BIBLIOTECA UNIVERSITÁRIA NO BRASIL: PELA (RE)ELABORAÇÃO DE MODELOS EPISTÊMICOS NO CONTEXTO DO SÉCULO XXI
}

\author{
O trabalho teórico, estou cada dia mais convencido, \\ tem maior incidência no mundo que o prático; se se \\ revoluciona primeiramente o reino das representações, \\ a realidade não permanece a mesma. (HEGEL apud
}

NICOLAU, 2019)

A contraposição entre documentos analisados, pesquisa empírica e literatura abordada ao longo da tese permite identificar que a Ciência da informação e a Biblioteconomia brasileiras, em grande medida, vêm priorizando discussões sobre a biblioteca universitária por um viés instrumental, a partir de abordagens que não incorporam criticamente a realidade social, educacional e cultural do país.

De modo geral, a biblioteca universitária ainda é conceitualmente delimitada a partir dos desígnios da Biblioteconomia moderna, aos quais são somados aspectos da sociedade da informação (MATTELART, 2002). Assim, à lógica da difusão de informações como forma de inserção dos sujeitos num modelo sociocultural homogêneo e homogeneizante, soma-se a representação da biblioteca universitária como dispositivo a ser reelaborado face a uma sociedade da informação singular; indicativo da desconsideração de desigualdades e diferenças contextuais, locais e globais. Desenvolvida em convergência com a noção de sociedade da informação, essa biblioteca está submetida a uma lógica discursiva em que a produção de informações é tratada como conjunto de relações que articulam de modo correspondente distribuição e acumulação. Caracteriza-se, então, a biblioteca universitária como dispositivo estritamente técnico, apolítico, instância cultural homogeneizante.

As lógicas desse modelo epistêmico de relação entre sujeito e patrimônio simbólico, todavia, conflitam com aquela do conhecimento. Assim, questões em torno das dinâmicas da informação científica, do conhecimento acadêmico e da apropriação cultural são, eventualmente, residuais. As fraturas que marcam a relação do estudante universitário com o patrimônio infodocumental e sua inserção na cultura científicoacadêmica seguem, via de regra, à margem dessas abordagens teóricas, afastando, desse modo, o debate que colocaria a biblioteca universitária como objeto de representações efetivamente democráticas. 
Para o desenvolvimento de uma biblioteca universitária comprometida com a democracia cultural, vinculada ao conhecimento compreendido como processo de trocas sociais e culturais, de contextualização, reunião e globalização de informações e saberes (MORIN, 2010), há que se reconhecer a complexa ordem de elementos implicados na relação do estudante brasileiro com o conhecimento. Tal questão demanda a proposição de caminhos ao enfrentamento de problemática que é indicativa de dificuldades de diálogo entre sistemas culturais distintos: o do estudante universitário (com seus contextos) e o da cultura científico-acadêmica (com seu patrimônio infodocumental).

O ingresso na graduação é o momento em que o sujeito entra em contato com um território simbólico novo, delimitado por um sistema cultural do qual o patrimônio infodocumental, sistematizado pela biblioteca universitária, é categoria privilegiada. Nesse contexto, está em causa o contato com repertórios representativos e lógicas constitutivas do conhecimento acadêmico; que escapam a muitos estudantes. Tanto a literatura como a pesquisa empírica (sobretudo os itens 4 e 5.1 da tese) revelaram que há um problema na relação do estudante universitário com o patrimônio infodocumental que não é da ordem do acúmulo. Muitos deles, provavelmente pela primeira vez, irão se deparar com autores, conteúdos, métodos e níveis de complexidade relativamente novos, ou mesmo desconhecidos. Assim, o sujeito que aprendeu apenas a reproduzir ideias encontrará dificuldades em se relacionar afirmativamente com o universo simbólico implicado na cultura científico-acadêmica. Trouxemos o indicativo de que, dentre os próprios estudantes, há aqueles que percebem necessidades e desejos de se redefinirem como sujeitos do conhecimento na esfera acadêmica sem, contudo, disporem de referenciais e condições concretas oferecidas pelo meio para tanto.

Nesse sentido, abordagens da questão sob viés difusionista ou da sociedade da informação, algo recorrente nos discursos analisados, não encaram essa ordem de problemas que é concreta, real e impacta sujeitos, sociedade, campos do conhecimento e, consequentemente, atuação profissional. Em grande medida, o estudante foi abordado pelos documentos analisados de modo abstrato, como uma figura sem contextos e singularidades.

$\mathrm{Na}$ medida em que esse encontro entre sistemas culturais diversos (o do estudante e o da cultura científico-acadêmica) não é percebido como questão fundante de hiatos culturais, a biblioteca universitária acaba contribuindo para a manutenção de distâncias simbólicas, restringindo-se à oferta de bens simbólicos e treinamento para acesso competente, dinâmica que privilegia a lógica do consumo de informação 
científica. O patrimônio que a biblioteca universitária disponibiliza não é simplesmente “texto", é também "contexto". Ou seja, é instância simbólica aberta aos processos de significação, demandando mediações culturais. Nesses termos, uma relação significativa com o patrimônio infodocumental extrapola tal repertório, bem como a própria biblioteca, pois é caminho à projeção do sujeito em dinâmicas de relações afirmativas com a ordem do conhecimento acadêmico. Com isso, não está em causa a relação do estudante com a biblioteca universitária e o patrimônio que disponibiliza como um fim em si mesmo, mas como condição à compreensão e intervenção simbólica do sujeito no mundo. Dito de outro modo, como condição à produção de conhecimento, esse modo de intervenção no real.

A importância da biblioteca universitária é assim compreendida como dispositivo cultural que ultrapassa lógicas do modelo transmissivista de conhecimento, por possibilitar o diálogo interdisciplinar, o olhar para além das especializações, as interfaces transdisciplinares responsáveis por alargar abordagens sobre o patrimônio infodocumental. Contudo, ressaltamos também a dimensão processual da relação sujeito-conhecimento, sem a qual esse patrimônio corre o risco de se tornar área sedimentada de signos, distante de possibilidades de sua atualização e ressignificação pelas novas gerações de estudantes e pesquisadores. Portanto, ao desenvolvimento de modelos epistêmicos que reconheçam o encontro entre estudante e patrimônio infodocumental é necessário considerar as representações de públicos da biblioteca universitária e de formação superior, pois são indicativas de concepções que lhe são atribuídas. Representações dos dispositivos da educação superior que não compreendam seus públicos, com suas diferenças e desigualdades, desconsiderando o multifário contexto nacional, limitam as condições para o reconhecimento e enfrentamento de problemas que marcam a realidade brasileira.

Nessa perspectiva, a biblioteca que projeta a imagem de seu público enquanto cliente tem por função a prestação de um serviço demandado por ele, tendo por objetivo sua satisfação, como vimos em certos discursos analisados. Em contraponto, a noção pressuporia também sujeitos com clareza e já iniciados nos meandros da cultura científico-acadêmica. A figura do cliente associada à biblioteca universitária e projetada na educação superior permite pressupor uma ação voltada ao consumo de bens simbólicos, e, como todo consumo, pautada por práticas facilitadoras de acesso e de escoamento de bens. A perspectiva da apropriação do patrimônio infodocumental, ao contrário, trata de estabelecer modos de relação com esse patrimônio, o que exige 
esforços visando à comunicação entre universos separados por distâncias culturais que se interpõem nos processos de significação. Nessa medida, a função educativa da biblioteca universitária não se rende, tampouco se limita, a processos de simples oferta informacional, o que equivaleria a abandonar o sujeito à própria sorte, mergulhado num contexto que lhe é estranho, mas do qual depende para construir sua identidade de estudante universitário, pesquisador, produtor de conhecimento e cultura. Assim, reconhecer o estudante é reconhecer também contextos que extrapolam aquele intramuros. Daí, a evidência e o sentido de compreender a mediação cultural como ato de criação, distinto da ideia de canal de facilitação.

Por sua vez, a concepção de conhecimento implicada na educação superior, e objetivada em modelos de formação, permite interrogar acerca das concepções de biblioteca universitária quando delineada a partir do apoio ao ensino. Ao se considerar a biblioteca universitária como instância de apoio a um ensino orientado por princípios e lógicas transmissivistas, no qual o conhecimento se constitui como objeto a ser distribuído, suas funções trarão marcas da disseminação informacional. Assim, pode ser categorizada a partir do modelo epistêmico da "biblioteca emporium" (PERROTTI, 2016), equiparada à ideia de entreposto de signos, aspecto que a fragiliza, considerandose o fosso cultural existente entre as esferas de produção e de recepção que caracterizam o sistema universitário brasileiro. De outro lado, a educação superior enquanto instância a serviço exclusivo do mercado de trabalho limita as possibilidades de proposição e desenvolvimento da biblioteca universitária enquanto dispositivo educativo e de caráter cultural.

Se tomamos a educação como caminho para a multiplicação da cultura (HOUAISS, 1992) - seja pela transmissão de conteúdos, valores e princípios, seja pelo ensino do pensar e do agir -, é preciso interrogar essa noção no âmbito da formação superior.

Vinculada a uma noção de cultura dotada de finalidade utilitária, a educação superior destina-se à formação com ênfase no campo da produção "material". Para Nietzsche (2003), sob esta tendência a cultura e, portanto, a educação superior, corresponderiam à criação de caminhos para obtenção de lucros, de vantagens econômicas. Nesse sentido, o propósito das IES seria delimitado quanto a fazer o sujeito progredir para se tornar apto a concorrer num mundo competitivo, para que, de seu conhecimento e saber, extraia formas de obter dividendos materiais pessoais. Sob tal viés, a educação superior é configurada unicamente como formação profissional, 
lidando somente com valores "aplicados", ou seja, o pensar é voltado a um fazer imediato, apartando-se os sujeitos de princípios axiológicos e de referências culturais mais amplas.

Contudo, para um mundo que supere a perspectiva da linearidade do produtivismo, esse aspecto precisa ser superado pela ideia do pensar e do agir como instâncias mutuamente articuladas, vinculadas a relações afirmativas com universos culturais abrangentes, que balizem a atuação do sujeito no mundo numa perspectiva democrática. Desse modo, propor a educação superior em termos de uma formação social e cultural como construção de si e do mundo implicaria reconhecer os contextos complexos que marcam o país e, em face deles, interrogar o significado dos dispositivos da educação, assumindo-se que eles refletem a ordem histórica. Nesses termos, transformações no terreno demandam repensar as estruturas existentes - dentre elas, a própria biblioteca universitária - sob a ótica de paradigma diverso do atual, com conhecimento e cultura sendo tomados como bens simbólicos implicados na noção de "viver juntos" (MORIN, 2000) e não como produtos, a serem geridos por um viés capitalista.

De outro lado, é preciso considerar o grau de autonomia de que a biblioteca universitária dispõe em relação à ordem disciplinar que orienta o ensino superior, já que defini-la a partir desse parâmetro significaria propô-la em termos adaptativos. Em nossa abordagem, a biblioteca universitária vincula-se ao processo do conhecimento, tal qual Burke (2012) indicou, por meio da imagem de um tripé que tem o conhecimento como eixo e na base as bibliotecas universitárias, as universidades e as disciplinas. Portanto, para o desenvolvimento de um modelo epistêmico à biblioteca universitária, é fundamental interrogar o conceito de conhecimento considerado e, também, a relação a ser estabelecida entre os diferentes sistemas implicados na formação. Assim, evidenciase a interdependência - e não a hierarquização - entre as diferentes esferas constitutivas da educação superior.

Vinculada ao conhecimento entendido como modo de intervenção no real, que pressupõe processos de contextualização, reunião e globalização de informações e saberes (MORIN, 2010; SANTOS, 2009), a biblioteca universitária é caracterizada como dispositivo educativo que lida com matéria simbólica aberta à produção de significados pelos estudantes. A abordagem, por seu lado, implica tomar o estudante como sujeito de palavra, assumindo o desenvolvimento de ações e tendo em vista saberes e fazeres constitutivos das dinâmicas de participação na cultura científico- 
acadêmica e de produção de conhecimento. Essa questão é imperiosa, dado que a especificidade do conhecimento acadêmico não é apenas da ordem de conteúdos intelectuais, mas implica métodos, fontes, formas de apreensão, apropriação e comunicação específicos. Nessa perspectiva, está em causa a biblioteca universitária como dispositivo de apropriação do patrimônio infodocumental, dimensão essencial à constituição do pensamento científico pelos universitários.

Por essas razões, à biblioteca universitária, considerada a ótica educativa, é demandada uma redefinição do modelo epistêmico que a alimenta, e, que tanto a Ciência da informação como a Biblioteconomia brasileiras não têm salientado em seus discursos, mas que certamente impacta não somente esse dispositivo, mas a própria relação entre sociedade e conhecimento acadêmico.

É forçoso reconhecer que, em grande medida, a biblioteca universitária vem sendo definida a partir das TIC, seguindo tendências para se fazer presente num contexto determinado por melhores e mais eficientes formas de disponibilizar informações. Sua função educativa é desconsiderada em abordagens que deixam de lado ideais de desenvolvimento de autonomia intelectual, de uma educação pautada por princípios de emancipação intelectual dos sujeitos.

No entanto, o alinhamento servil da biblioteca universitária às tecnologias corresponde à sua submissão não só a um ambiente técnico, mas também psíquico, no qual os sujeitos se desenvolvem. De fato, as TIC não são meros aparatos técnicos, dissociados dos processos de produção de sentidos. Da mesma forma que um livro ou um recurso audiovisual, os aparatos tecnológicos presentes no contexto da World Wide Web são tecnologias intelectuais. Dada sua natureza, seu papel não é secundário na formação dos sujeitos, caracterizando-se como ambiente que reúne técnicas, linguagens e relações, participando dos processos de formação do pensamento. Nesse contexto, as próprias fronteiras das noções de informação e conhecimento vêm sendo delineadas pela nova configuração tecnológica do mundo (GAUTIER, 2009). No domínio das bibliotecas universitárias, tal configuração demanda abordagens teóricas que compreendam a não neutralidade desses aparatos psicotécnicos que atuam na constituição do patrimônio sistematizado pelas bibliotecas e, também, na formação dos sujeitos.

$\mathrm{Na}$ esfera da constituição do patrimônio infodocumental, atrelar a biblioteca universitária às TIC abre espaço para problematizarmos as representações da matéria com que lida, reconhecendo o risco da redução de seu objeto - a memória cultural - à 
condição de memória das máquinas. Considerar essa distinção é fundamental, pois, conforme Lucas (1996), os processos de construção e estabilização da memória coletiva da humanidade se dão de modo diverso daquele da estabilização da memória das engrenagens técnicas. São construções distintas, permeadas por elementos sociais, culturais, políticos, dentre outros que precisam ser rigorosamente considerados no desenvolvimento da biblioteca universitária, sendo a memória coletiva uma construção humana que, portanto, inclui e implica os quadros da educação superior, assim como todos os demais.

Nessa perspectiva, a informação é uma construção social, produção de sujeitos imbuídos de seus repertórios, tendo como uma de suas dimensões a partilha simbólica, intrínseca ao "viver junto". Ainda segundo Lucas (1996), o patrimônio sistematizado pelas bibliotecas universitárias é dotado de sentidos que legitimam e organizam o imaginário coletivo, e assim constitui sentidos e também identidades. A partir de suas dimensões técnica, semiológica e pragmática, a biblioteca comunica, narra, conta uma história do conhecimento que ela guarda. Contribui, nesse sentido, tanto para o alargamento do patrimônio cultural como para encorajar sua comunidade a percorrer esse universo, implicado tanto nela como em dispositivos afins.

Em face dessas questões cabe, então, assumir o conceito de mediação cultural como categoria teórica para abordar a constituição do patrimônio infodocumental, na medida em que permite observar o funcionamento simbólico das sociedades sem reduzir os referidos aparatos - sejam as novas TIC, seja a própria biblioteca - a técnicas de transmissão.

Por sua vez, considerar que as TIC atuam na formação dos sujeitos, já que são também tecnologias intelectuais, permite indicar a insuficiência da abordagem competente da relação sujeito-informação. Ações reduzidas ao domínio de aparatos técnicos para acesso e uso minimizam a complexidade inerente à relação afirmativa com o patrimônio infodocumental, reduzindo o cerne da apropriação simbólica ao uso de ferramentas. Para Gautier (2009) é razoável a hipótese de que em breve praticamente será desnecessário ensinar aos estudantes o uso dessas ferramentas, com as quais estão cada vez mais habituados. A questão da educação não é adaptar o estudante ao uso de TIC; pelo contrário, está em causa um conhecimento técnico de aparelhos e sistemas, a compreensão de modos de funcionamento e alicerces desses aparatos psicotécnicos, assim como o desenvolvimento de saberes para se relacionar nessa esfera enquanto sujeito epistêmico. Portanto, para a cultura científico-acadêmica está em causa 
ultrapassar a esfera do saber usar a informação para atingir o conhecer, apropriando-se da ordem que engendra a produção da matéria simbólica que alimenta o pensamento científico.

Essa discussão compreende as dimensões cognitiva, metacognitiva, educacionais e culturais, e diz respeito ao desenvolvimento de ações institucionais concretas que extrapolem uma abordagem instrumental do uso de signos. Portanto, é definidora de condições à proposição de uma biblioteca universitária que participe dos processos de relação do estudante com o patrimônio infodocumental, tendo a mediação cultural como categoria que sintetiza o reconhecimento de uma dificuldade de relação sujeitouniversidade, face à existência de uma fratura entre os respectivos universos.

Nesse quadro, a interculturalidade coloca-se como noção teórica ao seu desenvolvimento, na medida em que diversidade, diferença, polifonia e polissemia constituem elementos-chave da lógica universitária, ou seja, do universitas, da universalidade, da totalidade. Desse modo, a interculturalidade é um conceito que possibilita romper com tendências que venham a valorizar a hierarquização de saberes. Contudo, sem deixar de lado as singularidades e especificidades que caracterizam o patrimônio cultural que fornece as bases da educação superior, cujos princípios e ordenamentos não são da ordem do conhecimento de senso comum, e coloca questões epistêmicas a serem enfrentadas face o hiato constatado entre estudantes, cultura e conhecimento acadêmico.

As discussões nos levam a tomar a biblioteca universitária como lugar de conhecimento, partindo-se da noção antropológica de lugar como identitário, relacional e histórico, portanto, simbolizado. Desse modo, há que considerar a biblioteca universitária a partir das possibilidades de percursos simbólicos que nela se realizam, dos discursos que ali se pronunciam e da linguagem que a caracteriza (AUGÉ, 2012), quando vinculada à noção de conhecimento como processo que pressupõe negociações culturais. Nessa perspectiva, em diálogo com Santaella (2007, p. $175^{47}$ apud REIS, 2013), a biblioteca universitária enquanto lugar de conhecimento se concretiza "pela interlocução das narrativas constituídas, pelas experiências individuais e coletivas dos

\footnotetext{
${ }^{47}$ SANTAELLA, Lúcia. Linguagens líquidas na era da mobilidade. São Paulo: Paulus, 2007.
} 
sujeitos em meio aos usos, pelo compartilhamento de significados acerca do lugar e dos próprios sujeitos que ali inscrevem suas marcas".

Nesses termos, afirmações sobre a importância da biblioteca enquanto espaço físico compreendido em perspectiva apenas funcional, pragmática - desconsiderando sua dimensão relacional, humana, cultural -, recusam seu caráter de lugar de conhecimento. Reconhecer essa dimensão implica considerar os sujeitos em suas singularidades e diferenças, redefinindo a ideia de público da biblioteca universitária. A pesquisadora Isabel Taukane, indígena da etnia Bakairi, ao ser questionada sobre como pensa a biblioteca, afirmou que "a biblioteca tem que se reinventar nesse tempo que está vivendo, eu como indígena vejo como muito fria a estrutura da biblioteca, pra mim eu colocaria umas redes, umas redes para ficar lendo ali" (ABERTURA..., 2020, 82 min). A indicação de que a biblioteca deveria dispor de redes, aproximando seus sentidos de sentidos do contexto indígena, reforça a ideia de lugar identitário, de relações entre sujeitos e com o patrimônio cultural, chamando a atenção para a importância do espaço na definição de proposições e configurações desse dispositivo. Assim, quando se pensa e propõe o espaço físico da biblioteca universitária, é indispensável considerar a dimensão cultural, axiológica, atribuída pelos sujeitos à materialidade dos ambientes, uma vez que o espaço é categoria que atua nos processos culturais, viabilizando-os ou dificultando-os. As diferenças, portanto, são entendidas como constitutivas da experiência do sujeito que, ao ingressar no universo da cultura científico-acadêmica, é levado a estabelecer novas interações de trocas mútuas com esse novo meio que amplia sua presença no mundo sem, contudo, abandonar o ser que é.

O outro lado da questão da biblioteca universitária enquanto espaço físico refere-se à importância do reconhecimento das desigualdades socioculturais, educacionais e econômicas que impactam na relação do estudante com a ordem simbólica acadêmica, podendo configurar barreiras aos processos que definem o estudante como sujeito do conhecimento, sobre os quais as relações presenciais favorecidas pelo compartilhamento de um espaço físico comum - exercem influência. A educação é um processo de interação que depende muito do vínculo humano, social, emocional tanto com os professores, como com os demais estudantes. Para Nicolelis (2020), a educação é uma experiência que moldou nosso cérebro, adaptado para o aprendizado social, implicando "a troca de experiências individuais que passam a ser parte do coletivo", para as quais lugares constituídos com tais fins são fundamentais. 
Essa discussão é essencial, sobretudo face ao contexto atual, em que a educação superior tende a ser profundamente impactada pela modalidade EaD no futuro próximo, na medida em que a pandemia da Covid-19 afetou amplamente a educação presencial no ano de 2020, colocando o ensino à distância como única alternativa possível em diferentes países. Dessa experiência coletiva podem advir profundas transformações, desde o ensino superior híbrido ou totalmente a distância emergindo como possibilidades que ganharão cada vez mais espaço no mundo atual. Nesse sentido, de um lado, há que se interrogar que referenciais devem pautar o lugar da biblioteca universitária nesse ensino. Em que medida a biblioteca participa da formação superior, tanto em termos de garantia de condições para uma relação significativa com o patrimônio infodocumental, como de aprendizagens e diálogos interculturais, e, sobretudo, de constituição da identidade do estudante como sujeito do conhecimento. Torna-se central evidenciar que a educação é um processo social, assim, observar as distinções entre virtual e presencial, analógico e digital mostra-se fundamental às bibliotecas universitárias numa modalidade de educação que pressuponha a EaD. Dado que o cérebro humano não é uma máquina tecnológica, desconsiderar a dimensão social e emocional nos processos do conhecimento é desconsiderar a própria condição humana, para a qual as relações presenciais são essenciais às aprendizagens. A biblioteca universitária, no contexto virtual, não deve ser traduzida como informação matéria entendida como repertório de sinais a serem enviados - sob o risco de ser tomada numa perspectiva em que interações sociais e culturais constituam mero acessório à formação do estudante. Se a esfera da biblioteca universitária tem necessariamente que compreender o ensino na modalidade à distância como nova realidade, essa questão afeta igualmente os campos de conhecimento responsáveis por produzir referências ao seu desenvolvimento (Biblioteconomia e a Ciência da informação brasileiras). Sobretudo porque no país a relação entre biblioteca e sociedade ainda mostra-se como um fenômeno sociocultural em debate, pressionado pela problemática do dispositivo imaterial como lugar de acesso à informação e lugar de conhecimento.

Neste contexto, ao estabelecimento de representações de biblioteca universitária, que compreendam sua função sociocultural e educativa, são demandadas referências conceituais, metodológicas e axiológicas capazes de orientar quadros funcionais, especialmente bibliotecários na construção de meios à relação dos sujeitos com o patrimônio infodocumental. Trata-se de ação criativa que, portanto, não se reduz ao 
conhecimento técnico da área, ou a uma lógica digital que desconsidere atributos humanos que não são digitais, "sim" ou "não", "um" e zero". Nessa perspectiva, tanto os atributos humanos do profissional - os quais concorrem à mediação cultural -, como o contexto de sua atuação - que implica seres humanos - integram formação profissional capaz de contribuir para o processo do conhecimento para além da oferta informacional, seja em termos da constituição de dispositivos, seja ainda no âmbito das interações diretas do bibliotecário com os públicos da biblioteca universitária.

Sob o risco da repetição, voltamos a afirmar que, sobretudo num contexto como o brasileiro, marcado por profundas fraturas nas relações entre sociedade e conhecimento, tais questões são prementes. Há que se propor a biblioteca universitária compreendendo o desenvolvimento de ações e metodologias que contribuam para o desenvolvimento de um pensamento científico em nossa sociedade. Portanto, um pensamento abstrato, conceitual, complexo e objetivo para o qual a relação crítica, criativa e rigorosa com o patrimônio infodocumental é essencial. Se não está em causa propor, de modo generalizado, a formação de cientistas, por outro lado, no âmbito do ensino superior há que se considerar sujeitos que interajam com o mundo e seus fenômenos com curiosidade epistemológica, capazes de diferenciar crenças, opiniões e conhecimento acadêmico. Sujeitos aptos a se relacionar com seu campo de conhecimento e de atuação profissional de forma crítica, criteriosa e autônoma. Tal abordagem implica que os sujeitos disponham de referenciais culturais que balizem suas ações e que possuam saberes e fazeres para se relacionar com o universo simbólico afirmativamente, desafio que coloca a biblioteca universitária em patamares distintos daqueles que por ora ocupa. Está em causa firmar a biblioteca universitária como dispositivo de mediação cultural que implica sujeitos - e seus contextos - e cultura científico-acadêmica - e seu patrimônio infodocumental -; dispositivo alinhado à noção de processo comunicacional como produção de sentidos. Assim, a consideração do adjetivo cultural é central ao conceito mediação cultural, porque estabelece e clarifica o objeto da mediação, no contexto da biblioteca universitária. Nesse quadro, primeiramente, a mediação cultural refere-se ao plano dos signos, à dimensão simbólica que integra a materialidade dos objetos culturais, não se restringindo, portanto, à ordem do texto, do documento, do conteúdo informacional. Entretanto, a referida dimensão simbólica e os complexos processos que envolvem sua apropriação extrapolam a esfera dos sujeitos. Em nossa sociedade, sobretudo, implica o universo dos dispositivos culturais: instâncias materiais, concretas, historicamente constituídas para a 
conservação, difusão e mediação cultural, replicadas em modelos conceituais essencialmente distintos, mas nem sempre bem resolvidos na prática e na teoria, sendo referidos, por vezes, de modo indistinto, como se observou em muitos discursos da área. Mediação cultural como episteme refere-se à abordagem que permite compreender a biblioteca universitária como dispositivo cultural de participação e construção de elos com a cultura e o patrimônio infodocumental, como meio intencionalmente preparado de educação de sujeitos do conhecimento.

No quadro da biblioteca universitária, a abordagem da mediação cultural embasa concepções e metodologias indispensáveis à geração de zonas de diálogo cultural, fragilizadas por múltiplas rupturas entre os sistemas nos quais a sociedade se insere e, no entanto, com as quais esse dispositivo tem que lidar se quiser assumir efetivamente seus objetivos educativos. Isto é, contribuir com o desenvolvimento de um pensamento científico a partir de referenciais, saberes e fazeres que possibilitem ao sujeito o diálogo com o patrimônio científico, artístico, literário e filosófico da humanidade, na medida em que a biblioteca universitária é categoria que se constitui pela seleção, reunião e permanência do patrimônio simbólico da humanidade.

Essa dimensão, com a qual a biblioteca universitária tem compromisso, afeta diretamente a ordem universitária e a ordem do conhecimento de um modo geral. Contudo, em nosso estudo depreendemos que, na atualidade, a biblioteca universitária vem sendo pautada pela pressão exercida pelos mecanismos informacionais tecnológicos baseados no imediatismo do consumo informacional. Frente a isso, em nosso país são demandadas revisões conceituais em torno desse dispositivo, com vistas ao desenvolvimento de outros modelos epistêmicos, caso se assuma como uma de suas funções atuar afirmativamente face às fraturas entre estudante universitário e conhecimento acadêmico. 


\section{CONSIDERAÇÕES FINAIS}

O estudo foi desenvolvido a partir do pressuposto de que atualmente a biblioteca universitária brasileira assenta-se sobre referenciais difusionistas, que nasceram com a Biblioteconomia moderna, sob certos ideais de democratização do conhecimento e da cultura.

O modelo, que tem por base a relação disseminação/assimilação simbólica, foi colocado em questão, tendo em vista perspectivas que consideram a centralidade da biblioteca universitária como dispositivo intrinsecamente educativo, e cujo projeto, para além de apoio ao ensino e da oferta informacional, inscreve-se no compromisso de atuar nos processos de participação afirmativa dos estudantes na cultura científico-acadêmica, como produtores de conhecimento. Em decorrência, propusemos como tese que redefinir o conceito de biblioteca universitária, voltado a processos de formação e socialização na cultura científico-acadêmica, implica inscrevê-la como dispositivo de apropriação do patrimônio infodocumental.

Em grande medida foi possível constatar que a biblioteca universitária vem sendo proposta a partir de abordagens que assumem conhecimento, cultura e formação superior a partir de um viés utilitário. Assim, a aquisição de conteúdos é questão de maior relevância, remetendo à noção de estudante como sujeito da informação, um ente abstrato - até mesmo idealizado -, bastando-lhe acessar e fazer uso da informação de modo competente. Nesse quadro, a biblioteca universitária é caracterizada, sobretudo, como provedora de conteúdos, sem cogitações acerca de problema fundante em sua esfera de ação, e que diz respeito à relação do estudante, principalmente o ingressante, com o patrimônio infodocumental e o papel desse dispositivo na contribuição à formação de um pensamento científico no país.

A crítica à biblioteca universitária representada a partir de modelo comunicacional linear de envio de informações a um receptor foi sustentada, visando evidenciar que o caráter central da produção de sentidos - como elemento do processo comunicacional -, demanda revisões conceituais que contribuam para seu desenvolvimento enquanto lugar de conhecimento, locus privilegiado dos atos de significação.

A questão da participação do estudante na cultura científico-acadêmica e no processo do conhecimento extrapola, nessa abordagem, a ordem do acúmulo sígnico, 
compreendendo-se que a apropriação do patrimônio infodocumental salienta dificuldades de diálogo entre sistemas culturais distintos: de um lado, o estudante universitário (com as complexidades de um contexto sócio-histórico marcado por descompassos diversos); de outro, os dispositivos que integram a cultura científicoacadêmica (com as resistências da matéria que constitui seu patrimônio infodocumental). A visão cristalizada de biblioteca universitária como entreposto informacional - "biblioteca emporium" -, privilegiando a lógica da oferta/consumo da informação científica, acaba contribuindo para a manutenção de fossos simbólicos assim como para o distanciamento dos não-iniciados nessa cultura, no que diz respeito aos processos de construção e participação no universo do conhecimento acadêmico.

Quando acesso e uso da informação pelos sujeitos (entendidos como usuários/ clientes) são enfatizados em abordagens difusionistas, que deixam de lado perspectivas de relações afirmativas com o patrimônio cultural, a biblioteca universitária, quando muito, participa da formação de um sujeito apto para integrar um mundo pronto e imóvel. Nesse sentido, são desconsideradas possibilidades de representação da biblioteca universitária como instância que contribui para a formação de sujeitos que intervêm no mundo, que o reelaboram a partir de relações afirmativas com o patrimônio cultural produzido e acumulado pela espécie humana.

Ao assumirmos que ciência e cultura são direitos inatos a todos os seres humanos, de fato patrimônio da humanidade, também afirmamos a importância do desenvolvimento de condições de possibilidade para que os estudantes participem de seus processos, redefinindo sua ordem a partir de suas especificidades e de seus valores. Desenvolver a biblioteca universitária considerando tal pressuposto, implica a elaboração de modelo epistêmico que compreenda a complexa ordem de questões, que buscamos abordar nesta tese, e que estão envolvidas no processo de apropriação do patrimônio infodocumental e dinâmicas correlatas, essencial ao desenvolvimento de uma cultura científica, como também à ressignificação do mundo em todas as esferas e dimensões.

Nessa direção, destacamos tratar-se de uma abordagem ancorada na compreensão da mediação cultural como modelo epistêmico, que considera a interculturalidade como categoria fundante ao desenvolvimento da biblioteca universitária enquanto dispositivo de comunicação sociocultural.

De modo orgânico, tendo a interculturalidade como princípio articulador de processos constitutivos do "viver junto" e, nesse âmbito, a mediação cultural como 
modelo epistêmico, um novo conceito de biblioteca universitária permitirá representála enquanto zona de intersecção entre culturas - a científico-acadêmica e as diversificadas culturas dos estudantes - , contribuindo para a comunicação entre universos separados por distâncias culturais que se interpõem à participação e significação do ser e estar universitários. Tal perspectiva altera, assim, as representações cristalizadas do conceito de biblioteca universitária - fundamentadas no fornecimento de meios de acesso ao conhecimento acadêmico -, e propõe que a biblioteca seja um dispositivo educativo, com papel na formação científica dos universitários.

A expectativa, nesses termos, é que a experiência desses sujeitos seja capaz de contribuir para o desenvolvimento das sociedades, a partir da ampliação do patrimônio acadêmico pelo reconhecimento da diversidade cultural e epistemológica do mundo como aspectos a serem integrados à sua ordem simbólica.

A mediação cultural como episteme, contudo, implicará ultrapassar discussões de caráter prático em torno da transmissão de informações pela biblioteca universitária, colocando como objeto central o desenvolvimento das suas dimensões técnica, semiológica e pragmática enquanto lugar de criação e construção de vínculos com o conhecimento.

A biblioteca universitária que contribua para dinâmicas de construção da democracia cultural no contexto acadêmico do século XXI, configura-se como dispositivo cada vez mais necessário, pois as relações dos sujeitos com o patrimônio simbólico estão sendo delineadas, em grande medida, sob a lógica do consumo informacional.

Conceber a biblioteca universitária a partir de modelo epistêmico diverso do atual, é fazer frente à trama de sentidos historicamente reiterada por discursos de acesso competente, consumo de informações, usuário, conhecimento útil, tecnicismo, dentre outros aspectos observados em nosso estudo. Foucault (1998) alertou-nos que existem momentos na vida em que "a questão de saber se se pode pensar diferentemente do que se pensa, e perceber diferentemente do que se vê, é indispensável para continuar a olhar ou a refletir". Para nós, a afirmação é um convite à revisão das bases conceituais que vêm forjando as representações da biblioteca universitária, o que irá demandar a desconstrução de determinadas estruturas arraigadas nos campos da Ciência da informação e Biblioteconomia brasileiras. 


\section{REFERÊNCIAS}

ADACHI, Ana Amélia C. T. Evasão de estudantes de cursos de graduação da USP ingressantes nos anos de 2002, 2003 e 2004. 2017. Tese (Doutorado em Educação) Faculdade de Educação, Universidade de São Paulo, São Paulo, 2017. Disponível em: http://www.teses.usp.br/teses/disponiveis/48/48134/tde-13092017-152310/pt-br.php . Acesso em 01 out. 2018.

AGAMBEN, Giorgio. O que é o contemporâneo? E outros ensaios. Tradução de Vinícius Nicastro Honesko. Chapecó: Argos, 2010.

ALBERTO Manguel. Direção: Daniel Augusto. In: INCERTEZAS críticas. [S.l.]: [S.n.], 2015, 1 vídeo (26 min), color. Episódio de série disponibilizada pelo Canal Curta.tv.br. Disponível em: https://canalcurta.tv.br/filme/?name=alberto_manguel. Acesso em: 03 fev. 2021.

ALBIERI, Sara. O conhecimento como questão: o papel da epistemologia na formação superior. Revista de Graduação USP, São Paulo, v. 1, n. 2, p. 13-20, 2016. Disponível em: https://doi.org/10.11606/issn.2525-376X.v1i2p13-20. Acesso em: 13 maio 2020.

ALMEIDA, George Ewerton Santos de. Ciência e cultura: os desafios e as possibilidades de (re)aproximação entre diferentes modos de conhecimento. 2019. Dissertação (Mestrado em Educação) - Faculdade de Educação, Universidade de São Paulo, São Paulo, 2019. Disponível em: https://doi.org/10.11606/D.48.2020.tde11122019-161446. Acesso em 13 maio 2020.

ALMEIDA JÚNIOR, Oswaldo Francisco de. Mediação da informação e múltiplas linguagens. Pesquisa brasileira em Ciência da Informação, Brasília, v. 2, n. 1, p. 89103, jan./dez. 2009. Disponível em:

https://revistas.ancib.org/index.php/tpbci/article/view/170/170 . Acesso em: 14 set. 2020.

APOSTLE, Richard; RAYMOND, Richard. Le paradigme de l'information. Bulletin des Bibliothèques de France, Paris, v. 32, n. 4, p. 290-299, 1987.

ARASZKIEWIEZ, Jacques; COULBAUT-LAZZARINI, Amélie; COUSTON, Frédéric. Médiation. In: PUBLICTIONNAIRE: dictionnaire encyclopédique et critique des publics. [S.1] : Université de Lorraine, 2019. Disponível em:

http://publictionnaire.huma-num.fr/notice/mediation. Acesso em: 14 set. 2020.

ARENDT, Hannah. Entre o passado e o futuro. $8^{\text {a }}$. ed. Tradução de Mauro W. Barbosa. São Paulo: Perspectiva, 2016. (Debates). E-book.

ARAÚJO, Cláudio Márcio; OLIVEIRA, Maria Claudia Santos Lopes de. Contribuições de Bourdieu ao tema do desenvolvimento adolescente em contexto institucional socioeducativo. Pesquisas e Práticas Psicossociais, v. 8, n. 2, p. 216-225, jul./dez. 2014. Disponível em: https://www.ufsj.edu.br/portal2repositorio/File/revistalapip/Volume8\%20n2/PPP\%208 2\%20Art \%209.pdf. Acesso em: 09 jul. 2020. 
BACHELARD, Gaston. Conhecimento comum e conhecimento científico. Revista Tempo Brasileiro, n. 28, 1972. [Excerto da obra Le Matérialisme rationnel, de 1953, publicado na referida revista]. Disponível em:

http://www.epistemologia.ufrj.br/index.php?option=com_content\&view=article\&id=3:c onhecimento-comum-e-conhecimento-cientifico .Acesso em: 30 nov. 2020.

BACHELARD, Gaston. La poétique de l'espace. 3e. ed. Paris: Les Presses universitaires de France, 1961 (Bibliothèque de philosophie contemporaine). Disponível em: https://gastonbachelard.org/wp-content/uploads/2015/07/BACHELARD-GastonLa-poetique-de-1-espace.pdf . Acesso em: 09 jul. 2020.

BARNETT, Ronald. The very idea of academic culture: what academy? What culture? Human affairs, v. 24, p.7-14, 2014. DOI: 10.2478/s13374-014-0202-4.

BARROS, Renata C B de. O ensino de leitura e a formação do sujeito do conhecimento. Domínios de Lingu@gem, v. 11, n. 4, p. 1152-1174, 7 nov. 2017. Disponível em:

http://www.seer.ufu.br/index.php/dominiosdelinguagem/article/view/38027. Acesso em 28 jan. 2021.

BATISTA, Carmem Lúcia. Mediação e apropriação da informação pública: a educação fiscal. 2014. Tese (Doutorado em Ciência da Informação) - Escola de Comunicações e Artes, Universidade de São Paulo, São Paulo, 2014. DOI:

10.11606/T.27.2015.tde-18052015-160609. Disponível em:

https://www.teses.usp.br/teses/disponiveis/27/27151/tde-18052015-160609/pt-br.php . Acesso em:14 set. 2020.

BECKER, Fernando. O sujeito do conhecimento: contribuições da epistemologia genética. Educação \& realidade, v. 24, n. 1, p. 73-89, jan./jun. 1999. Disponível em: https://seer.ufrgs.br/educacaoerealidade/article/view/55807 . Acesso em 09 jul. 2020.

BECKER, Howard. Truques da escrita: para começar e terminar teses, livros e artigos. Tradução de Denise Bottmann. Rio de Janeiro: Zahar, 2015.

BELLETATI, Valéria C. F. Dificuldades de alunos ingressantes na universidade pública: alguns indicadores para reflexões sobre a docência universitária. 2011. Tese (Doutorado em Educação) - Faculdade de Educação, Universidade de São Paulo, São Paulo, 2011. Disponível em: http://www.teses.usp.br/teses/disponiveis/48/48134/tde04082011-115006/pt-br.php. Acesso em 08 jul. 2020.

BETTELHEIM, Bruno. A psicanálise dos contos de fadas. $21^{\mathrm{a}}$. ed. Tradução de Arlene Caetano. Rio de Janeiro: Paz e Terra, 2010.

BORGES, Jorge Luis. A biblioteca de Babel. In: CAFÉ literário. Vale do Jequitinhonha: S.n., s.d. Disponível em: http://site.ufvjm.edu.br/cafeliterario/abiblioteca-de-babel-jorge-luis-borges/ . Acesso em: 08 dez. 2020.

BORGES, Jorge Luis. There are more things. S.d. Disponível em: http://varaldeleitura.blogspot.com/2014/06/conto-ulrica-de-jorge-luis-borges.html. Acesso em: 24 out. 2020. 
BOURDIEU, Pierre. A economia das trocas simbólicas. $5^{\text {a }}$. ed. São Paulo: Perspectiva, 2007.

BRUNER, Jerome. Acts of meaning: four lectures on mind and culture. Cambridge: Harvard University Press. 1990.

BUBER, Martin. Do diálogo e do dialógico. Tradução de Marta E. de S. Queiroz e Regina Weinberg. São Paulo: Perspectiva, 1982.

BURKE, Peter. Uma história social do conhecimento: de Gutenberg a Diderot. Tradução de Plínio Dentzien. Rio de Janeiro: Zahar, 2003.

BURKE, Peter. Uma história social do conhecimento II: da Enciclopédia a Wikipédia. Tradução de Denise Bottmann. Rio de Janeiro: Zahar, 2012.

CARROLL, Lewis. Aventuras de Alice no país das Maravilhas \& Através do espelho e o que Alice encontrou por lá. Tradução de Maria Luiza X. de A. Borges. Rio de Janeiro, Zahar, 2010. E-book.

CAUNE, Jean. Culture et communication: convergences théoriques et lieux de mediation. $2^{\mathrm{e}}$. ed. Grenoble: Presses universitaires de Grenoble, 2006.

CAUNE, Jean La médiation culturelle: une construction du lien social. Les enjeux de l'information et de la communication, $n$. 1, 2000. Disponível em:

https://lesenjeux.univ-grenoble-alpes.fr/2000/varia/04-la-mediation-culturelle-uneconstruction-du-lien-social. Acesso em:14 set. 2020.

CERTEAU, Michel de. A invenção do cotidiano: artes de fazer. $9^{\text {a }}$. ed. Tradução de Ephraim Ferreira Alves. Petrópolis: Vozes, 2003.

CHARLOT, Bernard. Da relação com o saber: elementos para uma teoria. Tradução de Bruno Magne. Porto Alegre: Artmed, 2008.

CHARTIER, Roger. A aventura do livro: do leitor ao navegador: conversações com Jean Lebrun. Tradução de Reginaldo C. C. de Moraes. São Paulo: UNESP: Imprensa Oficial, 1999.

CHAUI, Marilena. A universidade pública sob nova perspectiva. Revista Brasileira de Educação, Rio de Janeiro, n. 24, p. 5-15, set./dez. 2003. Disponível em: https://doi.org/10.1590/S1413-24782003000300002. Acesso em: 23 nov. 2020.

CHAUI, Marilena. Escritos sobre a universidade. São Paulo: UNESP, 2000.

COULON, Alain. A condição de estudante: a entrada na vida universitária. Tradução de Georgina G. dos Santos e Sônia Maria R. Sampaio. Salvador: EDUFBA, 2008.

CUNHA, Murilo B. da. A trajetória da biblioteca universitária no Brasil no período de 1901 a 2010. Encontros Bibli: revista eletrônica de biblioteconomia e ciência da informação, v. 21, n. 47, p.100-123, set./dez., 2016. Disponível em: 
https://periodicos.ufsc.br/index.php/eb/article/view/1518-2924.2016v21n47p100/32344 . Acesso em: 13 maio 2020.

DARRAS, Bernard. Étude des conceptions de la culture et de la médiation. MEI: médiation et information, Paris, n.19, p. 62-85, 2003. Disponível em: http://www.meiinfo.com/wp-content/uploads/revue19/ilovepdf.com_split_4.pdf. Acesso em:14 set. 2020.

DAVAllon, Jean. A mediação: a comunicação em processo? Prisma.com: revista de ciências e tecnologias de informação e comunicação, Porto, n. 4, p. 4-37, 2007. Disponível em: http://ojs.letras.up.pt/index.php/prismacom/article/view/2100 . Acesso em: 14 set. 2020.

DELEUZE, Gilles; GUATTARI, Félix. O que é a filosofia? Tradução de Bento Prado Jr. e Alberto Alonso Muñoz. São Paulo: Ed. 34, 2000. (Coleção Trans).

DOURADO, Ivan Penteado. Mediação didática no ensino superior: inventividade, níveis de abstração e o uso da metáfora como recurso didático no ensino de Sociologia. REBES - Rev. Brasileira de Ensino Superior, v. 2, n. 4, p. 34-45, out./dez. 2016. Disponível em: https://seer.imed.edu.br/index.php/REBES/article/view/1436/1068 . Acesso em: 27 jan. 2021.

DUBET, François. Faits d'école. Paris: Éditions de l'École des hautes études en sciences sociales, 2008.

DUFRÊNE, Bernardette; GELLEREAU, Michèle. La médiation culturelle: enjeux professionels et politiques. Hermès, n. 38, p. 199-206, 2004. Disponível em: https://www.cairn.info/revue-hermes-la-revue-2004-1-page-199.htm\# . Acesso em: 14 set. 2020.

ÉLÈVE. In: LITTRÉ, E. Dictionnaire Litré. s.d. Disponível em:

https://www.littre.org/definition/élève . Acesso em: 12 dez. 2018.

ENTRETENIMENTO. In: MICHAELIS. São Paulo: Melhoramentos, 2020.

ÉTUDIANT. In: CENTRE National de Ressources Textuelles et Lexicales. s.d. Disponível em: http://www.cnrtl.fr/etymologie/étudier. Acesso em 12 dez. 2018.

FERNANDES, Elisângela. O sujeito epistêmico de Piaget. In: NOVA Escola, 01 dez. 2010. Disponível em: https://novaescola.org.br/conteudo/1922/o-sujeito-epistemico-depiaget . Acesso em: 12 fev. 2019.

FREITAS, Ana Lúcia Souza de. Curiosidade epistemológica. In: STRECK, Danilo R.; REDIN, Euclides; ZITKOSKI, Jaime José (Org.). Dicionário Paulo Freire. Belo Horizonte: Autêntica, 2008. p. 107-109.

FREITAS, Lídia Silva. Na teia dos sentidos: análise do discurso da Ciência da Informação sobre a atual condição da informação. 2001. Tese (Doutorado em Ciências da Comunicação) - Escola de Comunicações e Artes, Universidade de São Paulo, São 
Paulo, 2001. Disponível em: https://teses.usp.br/teses/disponiveis/27/27143/tde19072005-165907/pt-br.php. Acesso em: 03 nov. 2020.

FONTENELLE, Isleide A. Para uma crítica ao discurso da inovação: saber e controle no capitalismo do conhecimento. Revista de Administração de Empresas, São Paulo, v. 52, n. 1, p. 100-108 jan/fev. 2012. Disponível em: http://dx.doi.org/10.1590/S003475902012000100008. Acesso em: 23 nov. 2020.

FOUCAULT, Michel. História da sexualidade 2: o uso dos prazeres. $8^{\mathrm{a}}$. ed. Tradução de Maria Thereza da Costa Albuquerque. Rio de Janeiro: Graal, 1998. (Biblioteca de Filosofia e História das Ciências; n. 15). E-book.

GARCÍA CANCLINI, Nestor. Diferentes, desiguais e desconectados: mapas da interculturalidade. Tradução de Luiz Sérgio Henriques. Rio de Janeiro: UFRJ, 2019.

GAUTIER, Julien. Vers une culture numérique lettrée ? Revue Skhole.fr: penser et repenser l'école. 2009. Disponível em: http://skhole.fr/vers-une-culture-numériquelettrée. Acesso em: 21 dez. 2020.

GEERTZ, Clifford. A interpretação das culturas. Rio de Janeiro: Livros Técnicos e Científicos, 1989.

GINZBURG, Carlo. Sinais: raízes de um paradigma indiciário. In: GINZBURG, Carlo. Mitos, emblemas e sinais. Tradução de Frederico Carotti. São Paulo: Companhia das Letras, 1989.

GIROUX, Henry. A esperança da educação radical: uma entrevista com Henry Giroux. In: GIROUX, Henry. Cruzando as fronteiras do discurso educacional: novas políticas em educação. Tradução de Magda França Lopes. Porto Alegre: Artmed, 1999. p. 19-30.

GOERGEN, Pedro. A crise de identidade da universidade moderna. In: PEREIRA, Elisabete Monteiro de A. et al... Escola e universidade na pós-modernidade. Campinas: Mercado das Letras; São Paulo: FAPESP, 2000. p. 101-161.

GOHARD-RADENKOVIC, Aline. La culture universitaire comme culture en soi. Travaux neuchâtelois de linguistique, v. 36, p. 9-24, 2002.

GOMES, Henriette Ferreira. Mediações para a leitura na universidade: ações docentes e da biblioteca. In: ENCONTRO NACIONAL DE PESQUISA EM CIÊNCIA DA INFORMAÇÃO, 9., 2008, São Paulo. Anais...São Paulo: ANCIB, 2008. Disponível em: http://enancib.ibict.br/index.php/enancib/ixenancib/paper/view/3033/2159 . Acesso em 09 jul. 2020.

GOMES, Henriette Ferreira. Práticas pedagógicas e espaços informacionais da universidade: possibilidades de integração na construção do espaço crítico. 2006. Tese (Doutorado em Educação) - Faculdade de Educação, Universidade Federal da Bahia, Salvador, 2006. Disponível em: https://repositorio.ufba.br/ri/bitstream/ri/11748/5/HenrietteFerreiraGomesTESE- 
PRÁTICAS-PEDAGÓGICAS-E-ESPAÇOS-INFORMACIONAIS-2006.pdf Acesso em: 09 jul. 2020.

GUMBRECHT, Hans. Ulrich. Produção de presença: o que o sentido não consegue transmitir. Tradução de Ana Isabel Soares. Rio de Janeiro: Contraponto, Ed. PUC-Rio, 2010.

HACKING, Ian. Ontologia histórica. Tradução de Leila Mendes. São Leopoldo: Unisinos, 2009. (Coleção Filosofia e ciência).

HAN, Byung-Chul. Bom entretenimento: uma desconstrução da história da paixão ocidental. Tradução de Lucas Machado. Petrópolis: Vozes, 2019.

HAN, Byung-Chul. No enxame: perspectivas do digital. Tradução de Lucas Machado. Petrópolis: Vozes, 2018.

HAN, Byung-Chul. Sociedade da transparência. Tradução de Enio Paulo Giachini. Petrópolis: Vozes, 2017a.

HAN, Byung-Chul. Sociedade do cansaço. Tradução de Enio Paulo Giachini. Petrópolis: Vozes, $2017 \mathrm{~b}$.

HOGGART, Richard. Molas deslassadas: uma nota sobre as desenraizadas e os ansiosos. In: HOGGART, Richard. As utilizações da cultura: aspectos da vida cultural da classe trabalhadora. Lisboa: Editorial Presença, 1973. (v. 2).

HOUAISS, Antonio. Educação e cultura. In: UNIVERSIDADE e educação. Campinas: Papirus, [1992]. (Coletânea CBE). p.227-237.

INEP/MEC. Resumo técnico do Censo da educação superior 2017. Brasília: INEP/MEC, 2019a. Disponível em:

http://download.inep.gov.br/educacao superior/censo superior/resumo tecnico/resumo _tecnico_censo_da_educacao_superior_2017.pdf. Acesso em: 08 maio 2020.

INEP/MEC. Pisa 2018 revela baixo desempenho escolar em leitura, matemática e ciências no Brasil. In: INEP/MEC[Brasília], 03 dez. 2019b. Disponível em: http://portal.inep.gov.br/artigo/-/asset_publisher/B4AQV9zFY7Bv/content/pisa-2018revela-baixo-desempenho-escolar-em-leitura-matematica-e-ciencias-no-brasil/21206 Acesso em: 13 maio 2020.

JACOB, Christian. Le cercle et la lignée. In: JACOB, Christian (Dir.). Lieux de savoir. Paris: Albin Michel, 2007. v. 1 Espaces et communautés. p.125-133.

JACOB, Christian. Lieux de savoir: a comparative approach to the tools and techniques of scholarly work. 2009. Conférence donnée à la Bibliothèque royale, Copenhague, 24 sept. 2009. Disponível em: http://www.asia-europe.uniheidelberg.de/fileadmin/Documents/Summer_School/Summer_School_2013/Christian Jacob_text_II.pdf . Acesso em: 19 dez. 2018.

JEANNERET, Yves. Médiation. In: LA SOCIETÉ de l'information: glossaire critique. Paris: La documentation française, 2005. p. 105-107. Disponível em: 
http://www.diplomatie.gouv.fr/fr/IMG/pdf/Glossaire_Critique.pdf . Acesso em: 14 set. 2020.

JESUS, Thaisa Alves Dias de. Biblioteca e Educação: um estudo sobre acolhimento em dispositivos culturais para crianças. 2018. Dissertação (Mestrado em Ciência da Informação) - Escola de Comunicações e Artes, Universidade de São Paulo, São Paulo, 2018. DOI: 10.11606/D.27.2018.tde-26122018-113757 . Disponível em: https://www.teses.usp.br/teses/disponiveis/27/27151/tde-26122018113757/publico/ThaisaAlvesDiasdeJesusVC.pdf. Acesso em: 09 jul. 2020.

KOPCKE FILHO, Henrique. Estratégias para desenvolver a metacognição e a compreensão de textos teóricos na Universidade. Psicologia Escolar e Educacional, v. 1, n. 2-3, 1997. DOI: 10.1590/S1413-85571997000100007 Disponível em: https://www.scielo.br/scielo.php?script=sci arttext\&pid=S141385571997000100007\&lng=pt\&tlng=pt. Acesso em: 09 jul. 2020.

KRENAK, Ailton. Ideias para adiar o fim do mundo. São Paulo: Companhia das Letras, 2019. E-book.

KRONBAUER, Luiz Gilberto. Consciência. In: STRECK, Danilo R.; REDIN, Euclides; ZITKOSKI, Jaime José (Org.). Dicionário Paulo Freire. Belo Horizonte: Autêntica, 2008. p. 86-88.

LALANDE, André. Vocabulário técnico e crítico da filosofia. São Paulo: Martins Fontes, 1993.

LARROSA Jorge. A operação ensaio: sobre o ensaiar e o ensaiar-se no pensamento, na escrita e na vida. Educação \& realidade, v. 29, n. 1, p. 27-43, jan./jun. 2004.

Disponível em: https://seer.ufrgs.br/educacaoerealidade/article/view/25417. Acesso em: 25 nov. 2020.

LARROSA Jorge. Notas sobre a experiência e o saber de experiência. Revista Brasileira de Educação, n. 19, p.20-28, jan./abr. 2002. Disponível em: http://www.scielo.br/pdf/rbedu/n19/n19a02.pdf. Acesso em: 3 ago. 2020.

LARROSA, Jorge. Tecnologias do eu e educação. In: SILVA, Tomaz Tadeu da (Org.). O sujeito da educação: estudos foucaultianos. Petrópolis: Vozes, 1994, p. 35-86.

LARROSA, Jorge. Tremores: escritos sobre experiência. Tradução de Cristina Antunes, João Wanderley Geraldi. Belo Horizonte: Autêntica, 2015. (Educação: experiência e sentido).

LATOUR, Bruno. Redes que a razão desconhece: laboratórios, bibliotecas, coleções. In: BARATIN, Marc; JACOB, Christian (Org.). O poder das bibliotecas: a memória dos livros no Ocidente. Tradução de Marcela Mortara. $3^{\mathrm{a}}$. ed. Rio de Janeiro: UFRJ, 2008. p. 21-44.

L'HOMME qui voulait classer le monde. Direção: Françoise Levie. [S.1.]: Sofidoc; Wild Heart; Memento; RTBF Télévision Belge, 2002. 1 DVD (60 min), NTSC, color. 
LOGAN, Robert K. Que é informação?: a propagação da organização na biosfera, na simbolosfera, na tecnosfera e na econosfera. Tradução de Adriana Braga. Rio de Janeiro: Contraponto : Ed. PUC-Rio, 2012.

LUCAS, Clarinda Rodrigues. Indexação: gesto de leitura do bibliotecário. 1996. Tese (Doutorado em Linguística) - Instituto de Estudos da Linguagem, Universidade Estadual de Campinas, Campinas, 1996. Disponível em: http://repositorio.unicamp.br/jspui/bitstream/REPOSIP/270726/1/Lucas_ClarindaRodri gues_D.pdf. Acesso em: $21 \mathrm{dez} .2020$.

LURIA, Alexander Romanovich. Diferenças culturais de pensamento. In: VIGOTSKII, L. S.; LURIA, A. R.; LEONTIEV, A. N. Linguagem, desenvolvimento e aprendizagem. São Paulo: Ícone, 1988. p. 39-58.

LUZ, Sueli Petry da; PERIM, Giana Lepre. Educação geral ou educação especializada: desafios da formação universitária In: PEREIRA, Elisabete M. de A. (org.).

Universidade e educação geral: para além da especialização. Campinas: Alínea, 2007. (Educação em debate). p. 171-197.

MACHADO, Rita de Cássia de Fraga. Autonomia. In: STRECK, Danilo R.; REDIN, Euclides; ZITKOSKI, Jaime José (Org.). Dicionário Paulo Freire. Belo Horizonte: Autêntica, 2008. p. 56-57.

MALEWSKA-PEYRE, Hanna; TAP, Pierre. Introduction: les enjeux de la socialisation. In: MALEWSKA-PEYRE, Hanna; TAP, Pierre (Org.). La socialisation de l'enfance a l'adolescence. Paris: Presses universitaires de France, 1991 (Psychologie d'aujourd'hui). p. 7-17.

MALINGRE, Marie-Laure; SERRES, Alexandre. Une culture informationnelle commune aux doctorants? In: DENECKER, Claire; DURAND-BARTHEZ, Manuel. La formation des doctorants à l'information scientifique et technique. Villeurbanne: Presses de 1'Enssib, 2011. p. 53-67. DOI: 10.4000/books.pressesenssib.932.

MANGUEL, Alberto. O poder da escrita. [S.l., s.n.], 2015. 1 vídeo (3 min 42 s). Canal Fronteiras do pensamento. Disponível em: https://www.youtube.com/watch?v=xPeBgtH6wfM. Acesso em: 03 ago. 2020.

MATTELART, Armand. História da sociedade da informação. Tradução de Nicolás Nyimi Campanário. São Paulo: Loyola, 2002.

MARTÍN-BARBERO, Jesús. De los medios a las mediaciones: comunicacion, cultura y hegemonia. Barcelona: Gustavo Gili, 1987.

MARTINS, Guilherme de Oliveira. Que complexidade hoje. In: MORIN, Edgar; LE MOIGNE, Jean-Louis. Inteligência da complexidade: epistemologia e pragmática. Lisboa: Instituto Piaget, 2007. (Coleção Epistemologia e sociedade, 260). p. 495-500.

MONTESQUIEU, Charles de Secondat. O gosto. Tradução de Teixeira Coelho. São Paulo: Iluminuras, 2009. 
MORIN, Edgar. Educar na era planetária: o pensamento complexo como método de aprendizagem pelo erro e incerteza humana. Tradução de Sandra T. Valenzuela. São Paulo: Cortez; Brasília: UNESCO, 2003.

MORIN, Edgar. Complexidade restrita, complexidade geral. In: MORIN, Edgar; LE MOIGNE, Jean-Louis. Inteligência da complexidade: epistemologia e pragmática. Lisboa: Instituto Piaget, 2007. (Coleção Epistemologia e sociedade, 260). p. 36-78.

MORIN, Edgar. Os desafios da complexidade. In: MORIN, Edgar (dir.). A religação dos saberes: o desafio do século XXI. 9a. ed. Tradução e notas de Flávia Nascimento. Rio de Janeiro: Bertrand Brasil, 2010. p. 559-567.

MORIN, Edgar. Os setes saberes necessários à educação do futuro. Tradução de Catarina E. F. da Silva e Jeanne Sawaya. Brasília: UNESCO, 2000.

NASCENTES, Antenor. Clientela, clínica, freguesia. In: NASCENTES, Antenor. Dicionário de sinônimos. $4^{\text {a }}$. ed. rev. e atual. Rio de Janeiro: Lexikon, 2011. (Obras de referência). p.179.

NASCIMENTO, Leandro dos Santos. Informação e educação: origens da Information Literacy - um estudo do relatório "The Information Service Environment Relationships and Priorities", de Paul Zurkowski. 2018. Dissertação (Mestrado em Ciência da Informação) - Escola de Comunicações e Artes, Universidade de São Paulo, São Paulo, 2018. Disponível em: https://teses.usp.br/teses/disponiveis/27/27151/tde-03122018153225/en.php . Acesso em: 23 nov. 2020. DOI: 10.11606/D.27.2018.tde-03122018153225 .

NEVES, Clarissa Eckert Baeta. Funções sociais do ensino superior hoje In: UNIVERSIDADE e educação. Campinas: Papirus, [1992]. (Coletânea CBE). p. 79-86.

NICOLAU, Marcos Fábio Alexandre. O conceito de Bilgung em Hegel. Sobral: Sertãocult; Edições UVA, 2019.

NICOLELIS, Miguel. Máquina de criar universos [Entrevista e matéria realizadas por Giuliana Bergamo]. In: ECOA, 29 nov. 2020. Disponível em: https://www.uol.com.br/ecoa/reportagens-especiais/miguel-nicolelis-nossa-forma-deaprender-e-por-meio-do-contato-social/ . Acesso em: 27 jan. 2021.

NIETZSCHE, Friedrich. Escritos sobre educação. Tradução de Noéli C. M. Sobrinho. $7^{\text {a }}$. ed. São Paulo: Loyola, 2003.

NUNES, Jefferson Veras; CAVALCANTE, Lídia Eugênia. Por uma epistéme mediacional na Ciência da Informação. Tendências da pesquisa brasileira em Ciência da Informação, v. 10, n. 2, 2017. Disponível em: https://revistas.ancib.org/index.php/tpbci/article/view/413 . Acesso em: 14 set. 2020.

NUNES, Martha Suzana Cabral; CARVALHO, Kátia de. As bibliotecas universitárias em perspectiva histórica: a caminho do desenvolvimento durável. Perspectivas em Ciência da Informação, v.21, n.1, p.173-193, jan./mar. 2016. Disponível em: 
http://portaldeperiodicos.eci.ufmg.br/index.php/pci/article/view/2572 . Acesso em: 13 maio 2020.

OLIVEIRA, Amanda Leal de. A negociação cultural: um novo paradigma para a mediação e a apropriação da cultura escrita. 2014. Tese (Doutorado em Ciência da Informação) - Escola de Comunicações e Artes, Universidade de São Paulo, São Paulo, 2004.

DOI: 10.16309/j.cnki.issn.1007-1776.2003.03.004.

OLIVEIRA, Lúcia Maciel Barbosa de. A cidade tecida pela cultura; a cultura tecida pela cidade, Ponto Urbe, n. 9, p.1-9, 2011. DOI : 10.4000/pontourbe.1806. Disponível em: http://journals.openedition.org/pontourbe/1806 . Acesso em: 03 fev. 2021.

ORDINE, Nuccio. A utilidade do inútil: um manifesto. Tradução de Luiz Carlos Bombassaro. Rio de Janeiro: Zahar, 2016.

ORLANDI, Eni P. Análise do discurso: princípios \& procedimentos. $10^{\text {a }}$. ed. Campinas: Pontes, 2012.

ORTEGA Y GASSET, José. Ideas y creencias (y otros ensayos de filosofia). Madrid : Revista de Occidente en Alianza Editorial, 2005.

ORTEGA Y GASSET, José. Missão da universidade. Versão portuguesa de Sant'anna Dionisio. [S.1]: Seara nova, 1946.

PEREIRA, Elisabete Monteiro de Aguiar. Educação geral: com qual propósito? In: PEREIRA, Elisabete M. de A. (org.). Universidade e educação geral: para além da especialização. Campinas: Alínea, 2007. (Educação em debate). p.65-91.

PERROTTI, Edmir. Confinamento cultural, infância e leitura. São Paulo: Summus, 1990. (Novas buscas em educação, v. 38).

PERROTTI, Edmir. Infoeducação: um passo além científico-profissional. Informação@Profissões, Londrina, v. 5, n. 2, p. 4 - 31, jul./dez. 2016. DOI: 10.5433/2317-4390. 2016v5n2p04. Disponível em: http:www.uel.br/revistas/infoprof/. Acesso em: 30 nov. 2020.

PERROTTI, Edmir. Sobre informação e protagonismo cultural. In: GOMES, Henriette F.; NOVO, Hildenise F. (Org). Informação e protagonismo social. Salvador: EDUFBA, 2017. p.11-26.

PERROTTI, Edmir; PIERUCCINI, Ivete. A mediação cultural como categoria autônoma. Informação \& informação, v. 19, n. 2, p. 1-22, 2014. DOI: 10.5433/19818920.2014v19n2p1. Disponível em: http://www.uel.br/revistas/uel/index.php/informacao/article/view/19992 . Acesso em: 14 set. 2020.

PERROTTI, Edmir; PIERUCCINI, Ivete; SÈRRES, Alexandre. Éducations aux medias, à l'information et au numérique au Brésil et en France: chemins croisés. Éducation 
comparée: revue de recherche international et comparative en education - nouvelle série. Bourdeaux, v.19, p.73-100, 2018.

PIERUCCINI, Ivete. A ordem informacional dialógica: estudo sobre a busca de informação em educação. 2004. Tese (Doutorado em Ciência da Informação) - Escola de Comunicações e Artes, Universidade de São Paulo, São Paulo, 2004. Disponível em: https://teses.usp.br/teses/disponiveis/27/27143/tde-14032005-144512/pt-br.php . Acesso em: 24 out. 2020.

POLIAK, Claude. La fureur de lire: des autodidactes. In : CHAUDRON, Martine; SINGLY, François de. Identité, lécture, Eécriture. Paris: Centre Georges Pompidou, Bibliothèque Publique d'Information, 1993. p. 59-75.

QUÉAU, Phillipe. Cibercultura e info-ética. In: MORIN, Edgar (dir.). A religação dos saberes: o desafio do século XXI. $9^{a}$. ed. Tradução e notas de Flávia Nascimento. Rio de Janeiro: Bertrand Brasil, 2010. p. 460-480.

RAMBALDI, Enrico. Mediação. In: ENCICLOPÉDIA Einaudi, v. 10, Dialéctica. Lisboa: Imprensa Nacional; Casa da Moeda, 1989, p. 143-174.

REIS, Breno Maciel de Souza. Pensando o espaço, o lugar e o não lugar em Certeau e Augé: perspectivas de análise a partir da interação simbólico no Foursquare.

Contemporânea, v. 11, n. 1, p. 136-148, 2013. Disponível em: https://www.epublicacoes.uerj.br/index.php/contemporanea/article/view/6969 Acesso em: 27 jan. 2021.

RÉMOND, Martine. La métacognition: une composante de la compréhension. Argos, n. 48, jul. 2011. Disponível em: http://www.educrevues.fr/ARGOS/AffichageDocument.aspx?iddoc=39721 . Acesso em: 09 jul. 2020.

RIBEIRO, Renato Janine. A universidade e a vida atual: Fellini não via filmes. $2^{\mathrm{a}}$. ed. São Paulo: Edusp, 2014.

RIBEIRO, Renato Janine. Entrevista com o Professor Renato Janine Ribeiro. Entrevistadores: Bruna Coelho, João Alex Costa Carneiro, Luana Fúncia, Talita Rosolen. Humanidades em diálogo, v. 1, n. 1, nov. 2007. DOI: 10.11606/issn.19827547.hd.2007.106093. Disponível em:

https://www.revistas.usp.br/humanidades/article/view/106093. Acesso em: 29 jan. 2021.

ROTHBARD, Murray N. O mito da eficiência. MISES: revista interdisciplinar de filosofia, direito e economia. v. 1, n. 2, p. 583-588 jul./dez. 2013. Disponível em: https://doi.org/10.30800/mises.2013.v1.517. Acesso em: 23 nov. 2020.

SABER-FAZER. In: WIKIPÉDIA: a enciclopédia livre. [S.1.: s.n.]: [s.d.]. Disponível em: https://pt.wikipedia.org/wiki/Saber-fazer. Acesso em: 08 jul. 2020.

SANTOS, Boaventura de Sousa. Para além do pensamento abissal: das linhas globais a uma ecologia de saberes. In: SANTOS, Boaventura de Sousa; MENESES, Maria Paula (org.). Epistemologias do Sul. Coimbra: Almedina, 2009. 
SANTOS, Bruna Bomfim Lessa dos; GOMES, Henriette Ferreira. Bibliotecas públicas do Brasil e o uso de dispositivos de comunicação da web social: o Facebook como espaço de mediação da informação. In: ENCONTRO NACIONAL DE PESQUISA EM CIÊNCIA DA INFORMAÇÃO, 16, 2015, João Pessoa. Anais.... João Pessoa: UFPB, 2015. Disponível em:

http://repositorios.questoesemrede.uff.br/repositorios/handle/123456789/2845 . Acesso em: 14 set. 2020 .

SANTOS JUNIOR, Roberto. L.; PINHEIRO, Lena Vania R. A abordagem teórica de A. I. Mikhailov sobre o termo informação científica. Revista digital de biblioteconomia e ciência da informação, v. 8, n. 1, p. 27-45, 2010. Disponível em: https://doi.org/10.20396/rdbci.v7i2.1955. Acesso em: 13 maio 2020.

SANTOS FILHO, José Camilo dos. Educação geral na universidade como instrumento de preservação da herança cultural, religação dos saberes e diálogos de culturas. In: PEREIRA, Elisabete M. de A. (org.). Universidade e educação geral: para além da especialização. Campinas: Alínea, 2007. (Educação em debate). p.17-64.

SANTOS NETO, João Arlindo dos. O estado da arte da mediação da informação: uma análise histórica da constituição e desenvolvimento dos conceitos. 2019. Tese (Doutorado em Ciência da Informação) - Faculdade de Filosofia e Ciências, Universidade Estadual Paulista "Júlio de Mesquita Filho", Marília, 2019. Disponível em: https://repositorio.unesp.br/handle/11449/181525 . Acesso em:14 set. 2020.

SARABIA, Bernabé. A aprendizagem e o ensino das atitudes. In: COLL, César et al. Os conteúdos na reforma: ensino e aprendizagem de conceitos, procedimentos e atitudes. Porto Alegre: Artmed, 2000. p. 119-178.

SCHOPFEL, Joachim. Les mutations du paysage de l'information scientifique. In: DENECKER, Claire; DURAND-BARTHEZ, Manuel. La formation des doctorants à l'information scientifique et technique. Villeurbanne: Presses de l'Enssib, 2017. p.1737. DOI: 10.4000/books.pressesenssib.932.

SERVET, Mathilde. Les bibliothèques troisième lieu: une nouvelle génération d'établissements culturels, Bulletin des bibliothèques de France (BBF), 2010, n. 4, p. 57-63. Disponível em: https://bbf.enssib.fr/consulter/bbf-2010-04-0057-001. Acesso em: 21 dez. 2020.

SIEVERS, Burkard. 'It is new, and it has to be done!': socio-analytic thoughts on betrayal and cynicism in organizational transformation. Culture and Organization, v. 13, n. 1, 2007. Disponível em: https://doi.org/10.1080/14759550601167222. Acesso em: 23 nov. 2020.

SIGNATES, Luiz. Estudo sobre o conceito de mediação. Novos olhares, n. 2, p. 37-49, 1998 1998. Disponível em: http://www.revistas.usp.br/novosolhares/article/view/51315/55382.

Acesso em:14 set. 2020.

SNOW, Charles Percy. As duas culturas e uma segunda leitura. Tradução de Geraldo de Souza e Renato de Azevedo. São Paulo: EDUSP, 2015. 
STRECK, Danilo R.; REDIN, Euclides; ZITKOSKI, Jaime José (Org.). Dicionário Paulo Freire. Belo Horizonte: Autêntica, 2008.

STRECK, Danilo R. Rigor/rigorosidade. In: STRECK, Danilo R.; REDIN, Euclides; ZITKOSKI, Jaime José (Org.). Dicionário Paulo Freire. Belo Horizonte: Autêntica, 2008. p. 362-363.

TEIXEIRA, Anísio. A universidade e a liberdade humana. Rio de Janeiro: Ministério da Educação e Cultura, 1954. (Os cadernos de cultura, 68).

TEIXEIRA COELHO, José. A cultura como experiência. In: RIBEIRO, Renato Janine (Org.). Humanidades: um novo curso na USP. São Paulo: Edusp, 2001. p. 65-101.

TENDÊNCIAS. In: MICHAELIS. São Paulo: Melhoramentos, 2020.

TINTO, Vincent. Leaving college: rethinking the causes and cures of student attrition. $2^{\text {nd }}$ ed. Chicago: the university of Chicago press, 1993.

TROMBETTA, Sérgio; TROMBETTA, Luis Carlos. Ética. In: STRECK, Danilo R.; REDIN, Euclides; ZITKOSKI, Jaime José (Org.). Dicionário Paulo Freire. Belo Horizonte: Autêntica, 2008. p. 166-168.

USUÁRIO. In: MICHAELIS. São Paulo: Melhoramentos, 2020.

VASCONCELLOS, Celso dos S.. Planejamento: projeto de ensino-aprendizagem e projeto político pedagógico. São Paulo: Libertad editora, 2007

VAZ FILHO, Florêncio Almeida. A rebelião indígena na UFOPA e os desafios da interculturalidade no ensino superior. Novos Olhares Sociais: Revista do PPGCSUFRB, v. 2, n. 1, p. 79-98. 2019. Disponível em:

https://www3.ufrb.edu.br/ojs/index.php/novosolharessociais/article/view/465. Acesso em: 30 nov. 2020.

VELHO. In: MICHAELIS. São Paulo: Melhoramentos, 2020.

VIGOTSKY, Lev Semenovich. A construção do pensamento e da linguagem.

Tradução de Paulo Bezerra. São Paulo: Martins Fontes, 2001.

VYGOTSKY, Lev Semenovich. A formação social da mente. Tradução de José Cipolla Neto, Luis S. Menna, Solange C. Afeche. $3^{a}$. ed. São Paulo: Martins Fontes, 1989.

VOGT, Carlos. A espiral da cultura científica. In: COMCIÊNCIA. [S.1.], 2003.

Disponível em:

https://www.comciencia.br/dossies-1-72/reportagens/cultura/cultura01.shtml . Acesso em: 03 fev. 2021.

ZITKOSKI, Jaime José. Diálogo/dialogicidade. In: STRECK, Danilo R.; REDIN, Euclides; ZITKOSKI, Jaime José (Org.). Dicionário Paulo Freire. Belo Horizonte: Autêntica, 2008. p.117-118. 


\section{APÊNDICES}

\section{APÊNCIDE A - ROTEIRO DA PESQUISA EMPÍRICA}

\section{Atividade 1 - Apresentação da proposta; diálogo sobre interesses}

Data: 25.03.2019, das $14 \mathrm{~h}$ às $16 \mathrm{~h}$

Local: Sala de áudio da biblioteca da ECA-USP

\section{Roteiro:}

Apresentação: indicar que o foco das ações a serem desenvolvidas são as relações do estudante universitário com o patrimônio simbólico implicado na educação superior.

Discutir o nosso processo colaborativo de construção de conhecimento: os estudantes realizarão o trabalho da disciplina e a pesquisadora realizará estudo empírico. Destacar que o trabalho final será sobre temática escolhida por eles, conforme seus desejos/interesses, a partir de diálogo com a docente responsável pela disciplina.

Expor que a participação é opcional, e que podem interrompê-la quando desejarem.

Propor duas atividades mensais, a serem agendadas conforme disponibilidades ${ }^{48}$. Investigar o que os mobilizou a participar das ações (explorar seus desejos, intenções, necessidades).

Após esse momento de reconhecimento, propor a leitura do conto $\mathrm{O}$ homem da cabeça de papelão, de João do Rio. Verificar se preferem fazer leitura compartilhada ou

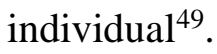

A partir do conto, promover o diálogo/partilha de impressões tendo como fios condutores: desenvolvimento de atitudes, o sujeito do conhecimento, a autonomia intelectual, o estabelecimento de relações com o patrimônio simbólico, consigo e com o mundo em perspectiva crítica e afirmativa.

Após, estimular que conheçam a biblioteca da ECA. Indagar se desejam realizar uma visita acompanhados pela pesquisadora, se há curiosidades, dar abertura para trazerem dúvidas posteriormente, etc. ${ }^{50}$

\footnotetext{
${ }^{48}$ A partir disso, foi definido que faríamos encontros quinzenais reunindo todos os participantes.

${ }^{49}$ Após a proposta, optaram por realizar leitura partilhada.

${ }^{50}$ Os estudantes não manifestaram interesse em realizar a atividade. Afirmaram que já haviam realizado uma visita guiada a partir de demanda de docente do curso.
} 
Estimular que comecem a refletir sobre aquilo desejam pesquisar para o trabalho final da disciplina.

\section{Atividade 2 - $O$ processo de pesquisa: o desejo de conhecer}

Data: 22.04.2019, das 14h às $16 \mathrm{~h}$

Local: Sala de áudio da Biblioteca da ECA-USP

\section{Roteiro:}

Expor a pesquisa como um processo; indicar a partir de quais elementos sugiro que realizemos as atividades ${ }^{51}$. Para chegarmos a uma configuração de roteiro, perguntar novamente por inquietações, dúvidas, o que esperam, o que desejam que exploremos nos encontros.

Perguntar se tiveram ideias sobre tema de pesquisa, investigar as motivações para as escolhas e se chegaram a realizar buscas por informações referentes ao tema.

Propor a leitura do conto There are more things, de Jorge Luis Borges ${ }^{52}$. Após a leitura, promover um debate observando tempo implicado no processo de conhecer, curiosidade epistemológica, interrogar o mundo, estabelecer perguntas para si.

Posteriormente, explorar a formulação de questões de pesquisa: $O$ quê? Quem? Quando? Onde? Como? Por quê? Há perguntas sobre as quais você já tem alguma ideia/O que já sabe sobre o tema?, inscrevendo-as na mobilização/desejo de conhecer.

Abordar a transformação do tema de pesquisa em conceitos e destes em palavras-chave para a realização de buscas.

\section{Atividade 3 - Pesquisar é investigar: a busca significativa}

Data: 08.05.2019, das $14 \mathrm{~h}$ às $16 \mathrm{~h}$

Local: Sala de áudio da biblioteca da ECA-USP

\section{Roteiro:}

\footnotetext{
${ }^{51}$ Sugestão de realização das atividades a partir dos seguintes passos da pesquisa: contato com a questão inicialmente proposta: estabelecimento de perguntas para si mesmo e formulação de questões de pesquisa; busca por informações em meios diversificados; leitura e registro de informações com reformulação de questões (construção de novas indagações a partir das informações que foram obtidas e apropriadas); busca por informações explorando fontes de informações não-convencionais; ordenação do pensamento para comunicação das informações obtidas.

${ }^{52}$ Os estudantes optaram por realizar leitura partilhada.
} 
1) Entabular uma conversa a partir desses pontos:

- Como está a definição do tema da pesquisa.

- Pensaram em termos (palavras-chave) pra iniciar a busca.

- Onde costumavam buscar informações.

- O que sentem em relação às pesquisas, aos trabalhos solicitados agora que estão na universidade (sentem alguma diferença? Começaram a buscar em outros locais? Mudaram o modo de buscar informações?).

- Se precisarem realizar um trabalho para alguma disciplina: como pensam em buscar, em quais recursos? Há algo de diferente entre como veem a pesquisa atualmente e antes de entrar na universidade e por quê?

2) Explorar a ideia de caminhos no processo de conhecer, a partir da leitura do trecho:

"Contam as histórias que o herói se constitui sempre a partir de uma busca que ele empreende no intuito de encontrar a solução para algum problema, que não é seu somente, mas de seu grupo. Para enfrentar o desafio, ele é preparado recebendo instruções de pessoas experientes ou de entidades mágicas que o alertam e o orientam sobre os perigos de seu trabalho; de sua parte, o herói vasculha, dentre seus pares, buscando quem possa ensinar-lhe algo novo, uma habilidade especial; observa como se comportam os melhores, os mais hábeis e inteligentes de seu grupo; mantém guardado um segredo ou talismã para ajudá-lo em momento crítico; reflete muito; imagina saídas ou soluções mirabolantes; concentra-se; desconfia das possibilidades ilimitadas de suas faculdades/capacidades; treina e confere tudo o que sabe e que tem acumulado. Depois, sai e põe em prática o que aprendeu para enfrentar os perigos. Seu percurso é marcado por inúmeros percalços que vão sendo vencidos, ou parcialmente perdidos, até a conclusão de sua tarefa. Ao término da saga, retorna finalmente transformado pelo processo que o faz detentor de um conhecimento, um saber que tão somente ele é possuidor, mas que compartilha com os seus ao voltar. A luta com o desconhecido é tratada como um momento de intensa produção, quando os sentidos, a cognição, o raciocínio, a imaginação, os afetos, as destrezas físicas são postas em funcionamento para enfrentar e chegar ao alvo desejado. A busca é, portanto, um procedimento fundamental do conhecimento em todas as suas dimensões, propiciando a apropriação do mundo e seus segredos pelo herói, bem como a constituição do herói como sujeito único e singular. O eu e o mundo se integram na e pela busca ${ }^{53}$ ".

Explorar a percepção de que diferentes caminhos podem levar a um mesmo lugar, mas também a lugares muitos distintos. Portanto, não somente o caminho enquanto porção entre duas coisas, mas, sim, o caminho vivido como percurso é o que irá definir o que

\footnotetext{
${ }^{53}$ Retirado de PIERUCCINI, Ivete. A ordem informacional dialógica: estudo sobre a busca de informação em educação. 2004. Tese (Doutorado em Ciência da Informação) - Escola de Comunicações e Artes, Universidade de São Paulo, São Paulo, 2004. Disponível em: https://teses.usp.br/teses/disponiveis/27/27143/tde-14032005-144512/pt-br.php . Acesso em: 24 out. 2020
} 
está no fim (o próprio sujeito com atitudes construídas, com uma nova experiência de si). A proposta é estimular que se interroguem sobre os caminhos da pesquisa.

Observar que a informação é um processo que inclui diferentes modalidades e naturezas de matéria sígnica. Logo podemos obtê-la por caminhos diversos (oralidade, anais de congresso, artigos, livros). Além disso, há o tempo implicado na produção do conhecimento.

Apresentar o quadro "Comparativo entre bases de dados especializadas e buscadores de acesso aberto" e então explorar: Google, Google Acadêmico e Portal de Busca integrada da USP:

- Apresentar os distintos recursos, observando suas especificidades e diferenças. Elaborar a mesma pesquisa nos três recursos para observarem as diferenças nos resultados obtidos.

Tabela 4 - Comparativo entre bases de dados especializadas e buscadores de acesso aberto

\begin{tabular}{|c|c|c|}
\hline \multicolumn{3}{|c|}{ Comparativo entre bases de dados especializadas e buscadores de acesso aberto } \\
\hline Critério & Bases de dados especializadas & Buscadores de acesso aberto \\
\hline Qualidade da informação & $\begin{array}{c}\text { Informação que passou por critérios de } \\
\text { seleção editorial, revisão por pares. } \\
\text { Fontes confiáveis. }\end{array}$ & $\begin{array}{c}\text { Dá acesso a um universo amplo que não implica } \\
\text { controle de qualidade da informação, veracidade, } \\
\text { fidedignidade. O leitor/pesquisador precisa saber } \\
\text { fazer um controle rigoroso da qualidade das } \\
\text { fontes. }\end{array}$ \\
\hline Recursos de pesquisa & $\begin{array}{c}\text { Recursos que permitem refinar a } \\
\text { pesquisa, o que tem reflexos na } \\
\text { pertinência das informações } \\
\text { recuperadas. Recursos para obter } \\
\text { métricas, analisar e gerenciar os } \\
\text { resultados. }\end{array}$ & $\begin{array}{c}\text { Recursos pouco desenvolvidos, poucos recursos } \\
\text { para trabalhar com os resultados recuperados. }\end{array}$ \\
\hline Organização da informação & $\begin{array}{c}\text { A informação é estruturada em campos } \\
\text { pesquisáveis: autor, título, assunto } \\
\text { dentre outros. }\end{array}$ & $\begin{array}{c}\text { A informação é pouco estruturada o que tem } \\
\text { reflexos nas possibilidades de refinamento da } \\
\text { pesquisa, que é mais limitada. }\end{array}$ \\
\hline
\end{tabular}

Fonte: Elaborado pela autora. 


\section{Atividade 4 - Leitura e registro de informações}

Data: 22.05.2019, das $14 \mathrm{~h}$ às $16 \mathrm{~h}$

Local: Sala de áudio da Biblioteca da ECA-USP

\section{Roteiro:}

Eixo: Ler é dialogar - a leitura como produção de sentidos. Ler e registrar informações são atos que demandam rigor e criticidade.

- Conteúdos que embasam a ação ${ }^{54}$ :

HASHIMOTO, Lica. Práticas de leitura e escrita acadêmicas: métodos de leitura (Aula 2, parte 1). Canal USP. Disponível em: https://www.youtube.com/watch?v=joRJ1PhqZiU . Acesso em: 03 dez. 2020. PELLEGRINO, Gabriela. Práticas de leitura e escrita acadêmicas: fichamento de texto (aula 8, parte 1). Canal USP. Disponível em: https://www.youtube.com/watch?v=R4Sag80pQ5Y . Acesso em: 03 dez. 2020.

Resgatar o encontro anterior para verificar se realizaram pesquisas, se utilizaram algo que vimos e, em caso positivo, se observaram alguma diferença.

Perguntar se definiram o tema da pesquisa e se a partir do que vimos surgiram necessidades e/ou desejos de algo para trabalharmos.

Entabular uma conversa em torno dos tópicos:

- Prática de leitura literária.

- Prática de leitura acadêmica. Entender como leem, o que fazem com o que leem. Quais os processos de anotação e construção a partir do lido.

- Como sentem/percebem a questão da leitura agora na universidade (sentem dificuldade em dialogar com os textos, conseguem ler todos os textos, falta tempo ou falta concentração, etc.).

- Elaboram fichamento, anotações, sínteses?

- Tendo por base os conteúdos do primeiro vídeo acima indicado, abordar alguns problemas no processo de leitura e como avançar: leitura fragmentada, tomar posição valorativa, ler sem considerar o todo, importância de desenvolver autonomia intelectual e de estruturas que fomentem a formação nessa direção.

Observar a importância da abertura ao uso de novos métodos. Experimentar-se desenvolvendo uma nova relação com o saber implica tempo e novos fazeres. A experiência de si na educação superior é outra, demanda novas formas de lidar com o conhecimento e, portanto, consigo mesmo.

Abordar concentração e foco a partir da exibição dos vídeos:

\footnotetext{
${ }^{54}$ Os vídeos não foram exibidos, mas forneceram bases à atuação da pesquisadora nessa atividade.
} 
CALABREZ, Pedro. Foco não é prestar atenção em tudo. Canal Casa do Saber. Disponível em: https://www.youtube.com/watch?v=fYoGkpYhcVE. Acesso em: 04 dez. 2020.

OAKLEY, Barbara. Método Pomodoro ${ }^{55}$. Disponível em:

https://www.youtube.com/watch?v=bDz7bUor51c . Acesso em: 08 jul. 2019.

\section{Fichamento:}

A partir do conteúdo do vídeo PELLEGRINO, Gabriela. Práticas de leitura e escrita acadêmicas: fichamento de texto (aula 8, parte 1). Canal USP, abordar métodos de fichamento, evidenciando a importância de utilizarem um método que funcione para eles. É rigoroso, não rígido.

Sugerir que façam o fichamento de um texto.

\section{Atividade 5 - Sínteses de aulas, informação oral, função das referências e citações,} referências de recursos audiovisuais

Data: 05.06.2019, das 14h às $16 \mathrm{~h}$

Local: Sala de vídeo da Biblioteca da ECA-USP

\section{Roteiro:}

Apresentar a proposta: assistir ao vídeo, tomar notas, compartilhar com o grupo, aprender sobre elaboração de sínteses, tipos de informação (oralidade), elaborar referência de recursos audiovisuais e citar informação obtida verbalmente (entrevista, sala de aula).

\section{$1^{\circ}$ momento:}

- Assistir ao seguinte vídeo e tomar notas:

DIÁLOGOS Biblioo \#5 - Briquet de Lemos. Canal Biblioo. Disponível em: https://www.youtube.com/watch?v=SdSCEU9W3KU\&feature=emb_logo Acesso em: 03. dez. 2020.

- Os participantes socializam suas anotações.

- Pesquisadora realiza mediações a partir dos pontos que trouxerem.

- Verificar impressões sobre a atividade: complexidade, concentração, distinção entre as anotações feitas pelos participantes, as ideias centrais do vídeo. Fazer

\footnotetext{
${ }^{55}$ No momento da organização da tese este vídeo não se encontrava mais disponível para visualização. O vídeo expunha a técnica Pomodoro, método de gerenciamento de tempo em que um cronômetro é utilizado para dividir a atividade em intervalos de 25 minutos de duração, separados por pequenos intervalos para pausa.
} 
um paralelo com a postura que têm quando estão em sala de aula, instigar que reflitam sobre como se relacionam com os conteúdos em aula.

- Apresentar possibilidades de elaboração de sínteses: marcações, destaques, anotações, método Cornell para anotações e recuperação posterior de informações.

\section{$2^{\circ}$ momento:}

- Discorrer sobre informação audiovisual, observar que qualidade e confiabilidade não estão no formato. Abordar informações orais, entrevistas, os próprios sujeitos como fontes de informação.

- Apresentar a função de referência/citação: remeter o leitor para a informação consultada pelo autor.

- Elaborar citação direta e indireta de entrevista publicada e não publicada.

- Fazer referência de vídeo online e em DVD, tanto de entrevista como de filme.

\section{Atividade 6 - Ordenação do pensamento e a escrita para se comunicar}

Data: 19.06.2019, das 14h às $16 \mathrm{~h}$

Local: Sala de vídeo da Biblioteca da ECA-USP

\section{Roteiro:}

\section{$1^{\circ}$ momento:}

- Apresentar a proposta do encontro: "Ordenação do pensamento diante das informações obtidas para sua comunicação". Trabalharemos com a ideia de que a escrita é um processo de comunicação, escrever é dialogar.

- Contextualizar e, em seguida, exibir o vídeo o vídeo:

FERRAZ, Marcus Sacrini. Práticas de leitura e escrita acadêmicas: introdução à escrita acadêmica (aula 10, parte 2). Canal USP. Disponível em: https://www.youtube.com/watch?v=fYoGkpYhcVE . Acesso em: 03 dez. 2020.

- Compartilhamento de impressões.

- Apresentar citação direta e indireta.

- Evidenciar a normalização bibliográfica como elemento constitutivo da comunicação acadêmica. Importância da apropriação dessas normas para que o estudante se comunique nessa linguagem.

- Indicar onde podem localizar as normas, apresentar sua estrutura e como consultá-las.

- Abrir espaço para perguntas. 
- Entregar cópia de trecho de livro em que o autor expõe modalidades dos trabalhos científicos:

SEVERINO, Antonio Joaquim. As modalidades do trabalho científico. In: SEVERINO, Antonio Joaquim. Metodologia do trabalho científico. 24 ed. rev. atual. São Paulo: Cortez, 2016. p. 199-210.

- Conversar sobre possibilidades para realizarmos uma atividade de avaliação do processo em data a ser agendada.

\section{Roteiro para avaliação das atividades pelos participantes ${ }^{56}$}

Identificação do respondente:

O campo identificação é de preenchimento opcional. Dada a natureza da pesquisa, o perfil do participante é um elemento importante, mas, caso prefira não se identificar, sinta-se à vontade para não preenchê-lo.

1) Caso tenha iniciado a participação no Programa e optado por não prosseguir, o que levou a essa escolha?

2) Avalie sua experiência no/com o programa de formação a partir dos seguintes eixos:

- Como passou a perceber/sentir a biblioteca da ECA depois da participação no programa?

- Como percebe agora o patrimônio cultural implicado na universidade?

- Você percebeu mudanças no seu interesse e no seu modo de estudar e pesquisar?

- Como sua participação no Programa refletiu no desenvolvimento do trabalho final da disciplina Fundamentos em Biblioteconomia, Documentação e Ciência da Informação?

3) Foram realizadas as seguintes atividades ao longo dos 6 encontros:

- Atividade 1 - Objetivo: Sensibilizar para a importância da apropriação social da informação e do protagonismo.

Ação: Leitura compartilhada do conto O homem da cabeça de papelão, de João do Rio.

- Atividade 2 - Objetivo: Discutir o processo de delimitação do tema da pesquisa. Ação: leitura compartilhada do conto There are more things, de Jorge Luis Borges, discussão sobre delimitação do tema de pesquisa e seleção de conceitos.

- Atividade 3 - Compreender a busca informacional como um processo.

Ação: leitura do trecho Caminhos, da tese da profa. Ivete Pieruccini. Pesquisa em distintos recursos informacionais (Google, Google Acadêmico e Portal de Busca Integrada da USP).

- Atividade 4-Compreender a leitura e o registro de informações como diálogos com o conhecimento.

\footnotetext{
${ }^{56}$ Esse roteiro conduziu à avaliação realizada presencialmente com os participantes. Para aqueles que não compareceram foi elaborado um formulário online com essas mesmas questões.
} 
Ação: Apresentação de estratégias de leitura e fichamento, exibição do vídeo "Foco não é prestar atenção em tudo", e de vídeo sobre o método Pomodoro.

- Atividade 5 - Sensibilizar para a importância da presença de si em sala de aula e das sínteses do conhecimento compartilhado em aula.

Ação: Visualização de entrevista com Antônio Agenor Briquet de Lemos, discussão sobre sínteses de aulas, exposição de método para tomada de notas, elaborar referências de recursos audiovisuais e entrevistas.

- Atividade 6 - Compreender o processo de escrita como ato comunicativo. Ação: apresentação de vídeo sobre escrita acadêmica, apresentação de normas da ABNT para trabalhos acadêmicos.

Sobre as atividades acima descritas:

- Qual a contribuição de cada atividade para a percepção da questão (objetivo) trabalhada no respectivo encontro?

- O que acharam dos conteúdos de cada atividade?

4) O que foi bom/ruim em relação ao formato dos encontros (dialógico)?

5) O que foi bom/ruim na atitude da pesquisadora?

6) O que o programa de formação propiciou a vocês que queiram comentar?

7) O que mais querem observar sobre o processo vivenciado? 


\section{APÊNDICE B - DELIMITAÇÃO DO PERFIL DOS PARTICIPANTES DA PESQUISA EMPÍRICA ${ }^{57}$}

\begin{tabular}{|c|c|}
\hline \multicolumn{2}{|c|}{ PARTICIPANTE: ESTUDANTE A } \\
\hline QUESTÃO & RESPOSTA \\
\hline Idade & 21 \\
\hline $\begin{array}{l}\text { Conte como é sua relação com o circuito cultural da cidade } \\
\text { (shows, espetáculos, teatro, cinema, museus, etc.) }\end{array}$ & $\begin{array}{l}\text { Eu as vezes vou ao cinema, tipo uma vez por mês. Os } \\
\text { outros meios culturais eu não possuo tanto contato. }\end{array}$ \\
\hline $\begin{array}{l}\text { Conte como é a sua relação, especificamente, com } \\
\text { bibliotecas (biblioteca escolar, pública, etc.) }\end{array}$ & $\begin{array}{l}\text { Só tive contato com bibliotecas das minhas escolas e a } \\
\text { universitária da FMU e da ECA. }\end{array}$ \\
\hline Conte sobre sua relação com a prática da leitura & $\begin{array}{l}\text { Eu lia bastante livros de ficção, terror e filosofia, mas de } \\
\text { uns anos para cá, eu estava focada em literatura para o } \\
\text { vestibular. }\end{array}$ \\
\hline Estado civil & Solteiro(a) \\
\hline Em que tipo de escola você estudou no ensino fundamental? & Todo em escola pública \\
\hline Em que tipo de escola você estudou no ensino médio? & Todo em escola pública \\
\hline $\begin{array}{l}\text { Você já cursou outra graduação anteriormente? } \\
\text { Caso tenha cursado outra graduação anteriormente e } \\
\text { concluído: Qual o curso e a instituição. Em que ano } \\
\text { concluiu? } \\
\text { Caso tenha cursado outra graduação anteriormente e não } \\
\text { concluído: Qual o curso e a instituição. Em que ano? Por } \\
\text { que não concluiu? }\end{array}$ & Não \\
\hline $\begin{array}{l}\text { Quantas pessoas da sua família moram com você? Considere } \\
\text { seus pais, irmãos, cônjuge, filhos e outros parentes que } \\
\text { moram na mesma casa com você. }\end{array}$ & 4 \\
\hline Qual o grau de escolarização dos seus pais? & $\begin{array}{l}\text { mãe (ensino médio- técnico); pai (fundamental } \\
\text { incompleto) }\end{array}$ \\
\hline $\begin{array}{l}\text { Você exerce alguma atividade remunerada? } \\
\text { Em caso positivo, por quantas horas semanais? } \\
\text { Caso não exerça atividade remunerada, pretende começar a } \\
\text { exercer ainda este ano? Em caso positivo, quais seus planos } \\
\text { em termos de horas/modalidade (estágio, trabalho fixo, } \\
\text { trabalho eventual, etc. }\end{array}$ & $\begin{array}{l}\text { Não / } \\
\text { Não respondeu }\end{array}$ \\
\hline Qual é, aproximadamente, a renda familiar mensal & Até 1,5 salário mínimo (até $\mathrm{R} \$ 1.497$ ) \\
\hline
\end{tabular}

57 As perguntas para delimitar o perfil socioeconômico do participante foram elaboradas a partir do Questionário do Estudante realizado pelo INEP, em 2017. Disponível em: http://inep.gov.br/questionario-do-estudante. Acesso em: 09 fev. 2019.

O participante designado como "Estudante J" não respondeu ao questionário. 


\begin{tabular}{|c|c|}
\hline \multicolumn{2}{|c|}{ PARTICIPANTE: ESTUDANTE B } \\
\hline QUESTÃO & RESPOSTA \\
\hline Idade & 18 \\
\hline $\begin{array}{l}\text { Conte como é sua relação com o circuito cultural da cidade } \\
\text { (shows, espetáculos, teatro, cinema, museus, etc.) }\end{array}$ & $\begin{array}{l}\text { Já tive muito mais contato com o circuito cultural, na } \\
\text { minha infância principalmente ia muito ao cinema, assisti } \\
\text { muitas peças de teatro e era levada a exposições. } \\
\text { Conforme fui crescendo, meu interesse por museus cresceu } \\
\text { e por isso já pude visitar muitos. Atualmente procuro } \\
\text { programações gratuitas (porque existem muitas na cidade e } \\
\text { porque minha situação financeira não permite muitos } \\
\text { gastos com lazer). }\end{array}$ \\
\hline $\begin{array}{l}\text { Conte como é a sua relação, especificamente, com } \\
\text { bibliotecas (biblioteca escolar, pública, etc.) }\end{array}$ & $\begin{array}{l}\text { Nunca tive grandes relações com bibliotecas escolares, } \\
\text { pois não possuía esse espaço nas escolas que frequentei. Já } \\
\text { com a Pública, tive muito contato desde pequena, porque } \\
\text { minha mãe trabalhava em uma delas como bibliotecária. }\end{array}$ \\
\hline Conte sobre sua relação com a prática da leitura & $\begin{array}{l}\text { Minha família sempre me influenciou a ler, desde a minha } \\
\text { alfabetização. Portanto, criei o hábito da leitura desde } \\
\text { cedo, e sempre o mantive. }\end{array}$ \\
\hline Estado civil & Solteiro(a) \\
\hline Em que tipo de escola você estudou no ensino fundamental? & Todo em escola privada (particular) \\
\hline Em que tipo de escola você estudou no ensino médio? & Parte no Brasil e parte no exterior \\
\hline $\begin{array}{l}\text { Você já cursou outra graduação anteriormente? } \\
\text { Caso tenha cursado outra graduação anteriormente e } \\
\text { concluído: Qual o curso e a instituição. Em que ano } \\
\text { concluiu? } \\
\text { Caso tenha cursado outra graduação anteriormente e não } \\
\text { concluído: Qual o curso e a instituição. Em que ano? Por } \\
\text { que não concluiu? }\end{array}$ & Não \\
\hline $\begin{array}{l}\text { Quantas pessoas da sua família moram com você? Considere } \\
\text { seus pais, irmãos, cônjuge, filhos e outros parentes que } \\
\text { moram na mesma casa com você. }\end{array}$ & 3 \\
\hline Qual o grau de escolarização dos seus pais? & Ambos possuem Ensino Superior completo. \\
\hline $\begin{array}{l}\text { Você exerce alguma atividade remunerada? } \\
\text { Em caso positivo, por quantas horas semanais? } \\
\text { Caso não exerça atividade remunerada, pretende começar a } \\
\text { exercer ainda este ano? Em caso positivo, quais seus planos } \\
\text { em termos de horas/modalidade (estágio, trabalho fixo, } \\
\text { trabalho eventual, etc. }\end{array}$ & $\begin{array}{l}\text { Não / } \\
\text { Sim, planejo começar um estágio assim que possível. }\end{array}$ \\
\hline
\end{tabular}




\begin{tabular}{|c|c|}
\hline \multicolumn{2}{|c|}{ PARTICIPANTE: ESTUDANTE C } \\
\hline QUESTÃO & RESPOSTA \\
\hline Idade & 38 \\
\hline $\begin{array}{l}\text { Conte como é sua relação com o circuito cultural da cidade } \\
\text { (shows, espetáculos, teatro, cinema, museus, etc.) }\end{array}$ & $\begin{array}{l}\text { Ultimamente, não tenho aproveitado muito as atrações } \\
\text { culturais oferecidas na cidade, por falta de tempo. }\end{array}$ \\
\hline $\begin{array}{l}\text { Conte como é a sua relação, especificamente, com } \\
\text { bibliotecas (biblioteca escolar, pública, etc.) }\end{array}$ & $\begin{array}{l}\text { Tenho por costume frequentar as bibliotecas da própria } \\
\text { Universidade, às vezes para estudar e pesquisar, outras } \\
\text { para emprestar algum livro. }\end{array}$ \\
\hline Conte sobre sua relação com a prática da leitura & $\begin{array}{l}\text { Leio diariamente, não apenas o que se pede na graduação, } \\
\text { ou seja, as leituras obrigatórias, mas, também, algum } \\
\text { cânone da literatura, já que tive pouco contato com as } \\
\text { obras mais consagradas, na minha infância e adolescência. }\end{array}$ \\
\hline Estado civil & Separado(a) judicialmente/divorciado(a) \\
\hline Em que tipo de escola você estudou no ensino fundamental? & Todo em escola pública \\
\hline Em que tipo de escola você estudou no ensino médio? & Todo em escola pública \\
\hline $\begin{array}{l}\text { Você já cursou outra graduação anteriormente? } \\
\text { Caso tenha cursado outra graduação anteriormente e } \\
\text { concluído: Qual o curso e a instituição. Em que ano } \\
\text { concluiu? } \\
\text { Caso tenha cursado outra graduação anteriormente e não } \\
\text { concluído: Qual o curso e a instituição. Em que ano? Por } \\
\text { que não concluiu? }\end{array}$ & $\begin{array}{l}\text { Sim e conclui / } \\
\text { Sou graduada em Letras com habilitação em Português e } \\
\text { Linguística pela Universidade de São Paulo. Ano de } \\
\text { conclusão em } 2016 .\end{array}$ \\
\hline $\begin{array}{l}\text { Quantas pessoas da sua família moram com você? Considere } \\
\text { seus pais, irmãos, cônjuge, filhos e outros parentes que } \\
\text { moram na mesma casa com você. }\end{array}$ & 3 \\
\hline Qual o grau de escolarização dos seus pais? & $\begin{array}{l}\text { Pai com ensino fundamental completo e mãe com segundo } \\
\text { grau incompleto. }\end{array}$ \\
\hline
\end{tabular}




\begin{tabular}{|c|c|}
\hline $\begin{array}{l}\text { Você exerce alguma atividade remunerada? } \\
\text { Em caso positivo, por quantas horas semanais? } \\
\text { Caso não exerça atividade remunerada, pretende começar a } \\
\text { exercer ainda este ano? Em caso positivo, quais seus planos } \\
\text { em termos de horas/modalidade (estágio, trabalho fixo, } \\
\text { trabalho eventual, etc. }\end{array}$ & $\begin{array}{l}\text { Não / } \\
\text { Não }\end{array}$ \\
\hline Qual é, aproximadamente, a renda familiar mensal & De 3 a 4,5 salários mínimos ( $\mathrm{R} \$ 2.994,01$ a $\mathrm{R} \$ 4.441,00)$ \\
\hline
\end{tabular}

\begin{tabular}{|c|c|}
\hline \multicolumn{2}{|c|}{ PARTICIPANTE: ESTUDANTE D } \\
\hline QUESTÃO & RESPOSTA \\
\hline Idade & 18 \\
\hline $\begin{array}{l}\text { Conte como é sua relação com o circuito cultural da } \\
\text { cidade (shows, espetáculos, teatro, cinema, museus, } \\
\text { etc.) }\end{array}$ & $\begin{array}{l}\text { Após minha mudança para São Paulo, poucas foram as vezes em que fiz algum } \\
\text { passeio cultural. Mas quando vinha a passeio, sempre fui em cinemas e em } \\
\text { museus; raras foram as vezes em que fui em teatros e shows. Mas de qualquer } \\
\text { forma, gostaria de ter uma relação mais atenuada com o circuito cultural da } \\
\text { cidade. }\end{array}$ \\
\hline $\begin{array}{l}\text { Conte como é a sua relação, especificamente, com } \\
\text { bibliotecas (biblioteca escolar, pública, etc.) }\end{array}$ & $\begin{array}{l}\text { Não sei dizer muito a respeito do presente, pois, ainda não desenvolvi uma rotina } \\
\text { dentro de bibliotecas em São Paulo. Mas penso que minha relação com } \\
\text { bibliotecas foi gradativa e ao mesmo tempo oscilante. Quando era menor, minha } \\
\text { mãe sempre me levava na Biblioteca Municipal em Águas de Santa Bárbara } \\
\text { (cidade onde morava), pois era a única biblioteca da cidade (fora as bibliotecas } \\
\text { escolares). Com o passar dos anos esse lugar não foi mais tão valorizado, se } \\
\text { tornando apenas um espaço para guardar livros antigos. } \\
\text { Porém, no meu ensino fundamental, tinha um contato muito forte com a } \\
\text { biblioteca da escola, pois toda semana tínhamos que pegar algum livro para levar } \\
\text { para casa, (fora as contações de história feitas pela bibliotecária da época, algo } \\
\text { que me marcou bastante). Entretanto, no ensino fundamental II, mudei de escola } \\
\text { e a relação com esse espaço mudou. Existia uma sala com livros, mas era tudo } \\
\text { muito bagunçado, sinto que seria um pouco errado chamar aquele lugar de } \\
\text { biblioteca. } \\
\text { No Ensino Médio, minha relação com a biblioteca foi muito boa. Mesmo que } \\
\text { fosse minúscula, já era um espaço diferenciado, passei muito tempo lá. } \\
\text { Hoje penso que meu envolvimento com o espaço mudou. Principalmente por } \\
\text { meu irmão ter se tornado um bibliotecário, minha visão sobre o assunto } \\
\text { amplificou bastante. E posso dizer que, nos últimos meses, isso aumentou ainda } \\
\text { mais. }\end{array}$ \\
\hline Conte sobre sua relação com a prática da leitura & $\begin{array}{l}\text { Minha relação com a leitura é um tanto quanto inconstante. Tenho o hábito de } \\
\text { começar a ler e de repente parar. Mas isso depende muito das circunstâncias, do }\end{array}$ \\
\hline
\end{tabular}




\begin{tabular}{|c|c|}
\hline & livro ou até mesmo da motivação. Acho que falta certo tipo de disciplina. \\
\hline Estado civil & Solteiro(a) \\
\hline $\begin{array}{l}\text { Em que tipo de escola você estudou no ensino } \\
\text { fundamental? }\end{array}$ & Todo em escola pública \\
\hline $\begin{array}{l}\text { Em que tipo de escola você estudou no ensino } \\
\text { médio? }\end{array}$ & Todo em escola técnica pública \\
\hline $\begin{array}{l}\text { Você já cursou outra graduação anteriormente? } \\
\text { Caso tenha cursado outra graduação anteriormente } \\
\text { e concluído: Qual o curso e a instituição. Em que } \\
\text { ano concluiu? } \\
\text { Caso tenha cursado outra graduação anteriormente } \\
\text { e não concluído: Qual o curso e a instituição. Em } \\
\text { que ano? Por que não concluiu? }\end{array}$ & Não \\
\hline $\begin{array}{l}\text { Quantas pessoas da sua família moram com você? } \\
\text { Considere seus pais, irmãos, cônjuge, filhos e } \\
\text { outros parentes que moram na mesma casa com } \\
\text { você. }\end{array}$ & 3 \\
\hline Qual o grau de escolarização dos seus pais? & Pós graduação e graduação. \\
\hline $\begin{array}{l}\text { Você exerce alguma atividade remunerada? } \\
\text { Em caso positivo, por quantas horas semanais? } \\
\text { Caso não exerça atividade remunerada, pretende } \\
\text { começar a exercer ainda este ano? Em caso } \\
\text { positivo, quais seus planos em termos de } \\
\text { horas/modalidade (estágio, trabalho fixo, trabalho } \\
\text { eventual, etc. }\end{array}$ & $\begin{array}{l}\text { Não / } \\
\text { Sim, pretendo começar esse ano, em um estágio preferivelmente, com } 6 \text { horas } \\
\text { diárias no máximo. }\end{array}$ \\
\hline Qual é, aproximadamente, a renda familiar mensal & De 3 a 4,5 salários mínimos ( $\mathrm{R} \$ 2.994,01$ a $\mathrm{R} \$ 4.441,00)$ \\
\hline
\end{tabular}

\begin{tabular}{|l|l|}
\hline \multicolumn{2}{|c|}{ PARTICIPANTE: ESTUDANTE E } \\
\hline QUESTÃO & RESPOSTA \\
\hline Idade & 26 \\
\hline $\begin{array}{l}\text { Conte como é sua relação com o circuito cultural da cidade } \\
\text { (shows, espetáculos, teatro, cinema, museus, etc.) }\end{array}$ & $\begin{array}{l}\text { Esporadicamente vou ao cinema, tanto pra filmes mais } \\
\text { populares como em algumas mostras de cinema. Não } \\
\text { tenho o hábito de ir a shows, espetáculos de teatro ou } \\
\text { museus }\end{array}$ \\
\hline $\begin{array}{l}\text { Conte como é a sua relação, especificamente, com } \\
\text { bibliotecas (biblioteca escolar, pública, etc.) }\end{array}$ & $\begin{array}{l}\text { Tive uma relação mais com a biblioteca universitária em } \\
\text { minha primeira graduação, para os estudos das matérias }\end{array}$ \\
\hline Conte sobre sua relação com a prática da leitura & Leio todos os dias \\
\hline
\end{tabular}




\begin{tabular}{|c|c|}
\hline Estado civil & Solteiro(a) \\
\hline Em que tipo de escola você estudou no ensino fundamental? & Todo em escola privada (particular) \\
\hline Em que tipo de escola você estudou no ensino médio? & Todo em escola privada (particular) \\
\hline $\begin{array}{l}\text { Você já cursou outra graduação anteriormente? } \\
\text { Caso tenha cursado outra graduação anteriormente e } \\
\text { concluído: Qual o curso e a instituição. Em que ano } \\
\text { concluiu? } \\
\text { Caso tenha cursado outra graduação anteriormente e não } \\
\text { concluído: Qual o curso e a instituição. Em que ano? Por } \\
\text { que não concluiu? }\end{array}$ & $\begin{array}{l}\text { Sim e conclui / } \\
\text { Meteorologia - IAG - USP. No início de } 2016\end{array}$ \\
\hline $\begin{array}{l}\text { Quantas pessoas da sua família moram com você? Considere } \\
\text { seus pais, irmãos, cônjuge, filhos e outros parentes que } \\
\text { moram na mesma casa com você. }\end{array}$ & Nenhuma \\
\hline Qual o grau de escolarização dos seus pais? & Superior completo \\
\hline $\begin{array}{l}\text { Você exerce alguma atividade remunerada? } \\
\text { Em caso positivo, por quantas horas semanais? } \\
\text { Caso não exerça atividade remunerada, pretende começar a } \\
\text { exercer ainda este ano? Em caso positivo, quais seus planos } \\
\text { em termos de horas/modalidade (estágio, trabalho fixo, } \\
\text { trabalho eventual, etc. }\end{array}$ & $\mathrm{Sim} / 40 \mathrm{~h}$ \\
\hline Qual é, aproximadamente, a renda familiar mensal & De 6 a 10 salários mínimos ( $\mathrm{R} \$ 5.988,01$ a $\mathrm{R} \$ 9.980,00)$ \\
\hline
\end{tabular}




\begin{tabular}{|c|c|}
\hline \multicolumn{2}{|c|}{ PARTICIPANTE: ESTUDANTE F } \\
\hline QUESTÃO & RESPOSTA \\
\hline Idade & 19 \\
\hline $\begin{array}{l}\text { Conte como é sua relação com o circuito cultural da cidade } \\
\text { (shows, espetáculos, teatro, cinema, museus, etc.) }\end{array}$ & $\begin{array}{l}\text { Não frequento esses espaços o tanto que gostaria, mas } \\
\text { sempre que posso vou ao cinema, vejo peças de teatro e } \\
\text { vou a shows. }\end{array}$ \\
\hline $\begin{array}{l}\text { Conte como é a sua relação, especificamente, com } \\
\text { bibliotecas (biblioteca escolar, pública, etc.) }\end{array}$ & $\begin{array}{l}\text { Nao frequento e nunca frequentei bibliotecas fora do } \\
\text { ambiente escolar/acadêmico }\end{array}$ \\
\hline Conte sobre sua relação com a prática da leitura & $\begin{array}{l}\text { Adoro ler e leio sempre que posso. Geralmente literatura } \\
\text { adolescente, não gosto muito de leituras densas. }\end{array}$ \\
\hline Estado civil & Solteiro(a) \\
\hline Em que tipo de escola você estudou no ensino fundamental? & Todo em escola privada (particular) \\
\hline Em que tipo de escola você estudou no ensino médio? & Todo em escola pública \\
\hline $\begin{array}{l}\text { Você já cursou outra graduação anteriormente? } \\
\text { Caso tenha cursado outra graduação anteriormente e } \\
\text { concluído: Qual o curso e a instituição. Em que ano } \\
\text { concluiu? } \\
\text { Caso tenha cursado outra graduação anteriormente e não } \\
\text { concluído: Qual o curso e a instituição. Em que ano? Por } \\
\text { que não concluiu? }\end{array}$ & Não \\
\hline $\begin{array}{l}\text { Quantas pessoas da sua família moram com você? Considere } \\
\text { seus pais, irmãos, cônjuge, filhos e outros parentes que } \\
\text { moram na mesma casa com você. }\end{array}$ & 1 \\
\hline Qual o grau de escolarização dos seus pais? & Superior completo \\
\hline $\begin{array}{l}\text { Você exerce alguma atividade remunerada? } \\
\text { Em caso positivo, por quantas horas semanais? } \\
\text { Caso não exerça atividade remunerada, pretende começar a } \\
\text { exercer ainda este ano? Em caso positivo, quais seus planos } \\
\text { em termos de horas/modalidade (estágio, trabalho fixo, } \\
\text { trabalho eventual, etc. }\end{array}$ & $\begin{array}{l}\text { Não/ } \\
\text { Não respondeu }\end{array}$ \\
\hline Qual é, aproximadamente, a renda familiar mensal & De 4,5 a 6 salários mínimos ( $\mathrm{R} \$ 4.441,01$ a $\mathrm{R} \$ 5.988,00)$ \\
\hline
\end{tabular}




\begin{tabular}{|c|c|}
\hline \multicolumn{2}{|c|}{ PARTICIPANTE: ESTUDANTE G } \\
\hline QUESTÃO & RESPOSTA \\
\hline Idade & 18 \\
\hline $\begin{array}{l}\text { Conte como é sua relação com o circuito cultural da cidade } \\
\text { (shows, espetáculos, teatro, cinema, museus, etc.) }\end{array}$ & Frequento cinemas e bibliotecas. \\
\hline $\begin{array}{l}\text { Conte como é a sua relação, especificamente, com } \\
\text { bibliotecas (biblioteca escolar, pública, etc.) }\end{array}$ & $\begin{array}{l}\text { Tenho contato com a biblioteca universitária, mas gostaria } \\
\text { de saber mais sobre seus recursos. }\end{array}$ \\
\hline Conte sobre sua relação com a prática da leitura & $\begin{array}{l}\text { Comecei a ler aos } 4 \text { anos e não parei desde então. Livros } \\
\text { sempre foram parte da minha rotina, leio com prazer tanto } \\
\text { os textos para a faculdade quanto os livros para lazer. }\end{array}$ \\
\hline Estado civil & Solteiro(a) \\
\hline Em que tipo de escola você estudou no ensino fundamental? & Todo em escola privada (particular) \\
\hline Em que tipo de escola você estudou no ensino médio? & Todo em escola privada (particular) \\
\hline $\begin{array}{l}\text { Você já cursou outra graduação anteriormente? } \\
\text { Caso tenha cursado outra graduação anteriormente e } \\
\text { concluído: Qual o curso e a instituição. Em que ano } \\
\text { concluiu? } \\
\text { Caso tenha cursado outra graduação anteriormente e não } \\
\text { concluído: Qual o curso e a instituição. Em que ano? Por } \\
\text { que não concluiu? }\end{array}$ & Não \\
\hline $\begin{array}{l}\text { Quantas pessoas da sua família moram com você? Considere } \\
\text { seus pais, irmãos, cônjuge, filhos e outros parentes que } \\
\text { moram na mesma casa com você. }\end{array}$ & 4 \\
\hline Qual o grau de escolarização dos seus pais? & Superior completo \\
\hline $\begin{array}{l}\text { Você exerce alguma atividade remunerada? } \\
\text { Em caso positivo, por quantas horas semanais? } \\
\text { Caso não exerça atividade remunerada, pretende começar a } \\
\text { exercer ainda este ano? Em caso positivo, quais seus planos } \\
\text { em termos de horas/modalidade (estágio, trabalho fixo, } \\
\text { trabalho eventual, etc. }\end{array}$ & $\begin{array}{l}\text { Não/ } \\
\text { Sim, pretendo fazer um estágio no segundo semestre. }\end{array}$ \\
\hline Qual é, aproximadamente, a renda familiar mensal & De 10 a 30 salários mínimos $(\mathrm{R} \$ 9.980,01$ a $\mathrm{R} \$ 29.940,00)$ \\
\hline
\end{tabular}




\begin{tabular}{|c|c|}
\hline \multicolumn{2}{|c|}{ PARTICIPANTE: ESTUDANTE H } \\
\hline QUESTÃO & RESPOSTA \\
\hline Idade & 21 \\
\hline $\begin{array}{l}\text { Conte como é sua relação com o circuito cultural da cidade } \\
\text { (shows, espetáculos, teatro, cinema, museus, etc.) }\end{array}$ & $\begin{array}{l}\text { Eu consumo muitos filmes(já vi 1250) e séries, por } \\
\text { streaming e por downloads. Amo muito teatro, cinema e } \\
\text { museus, mas vergonhosamente não os frequento muito. } \\
\text { Algo como } 3 \text { ou } 4 \text { vezes por ano cada um. Esses três me } \\
\text { interessam inclusive a nível de querer me graduar em } \\
\text { algum. }\end{array}$ \\
\hline $\begin{array}{l}\text { Conte como é a sua relação, especificamente, com } \\
\text { bibliotecas (biblioteca escolar, pública, etc.) }\end{array}$ & $\begin{array}{l}\text { Eu consumo muitos filmes(já vi 1250) e séries, por } \\
\text { streaming e por downloads. Amo muito teatro, cinema e } \\
\text { museus, mas vergonhosamente não os frequento muito. } \\
\text { Algo como } 3 \text { ou } 4 \text { vezes por ano cada um. Esses três me } \\
\text { interessam inclusive a nível de querer me graduar em } \\
\text { algum. }\end{array}$ \\
\hline Conte sobre sua relação com a prática da leitura & $\begin{array}{l}\text { Comecei a gostar de ler quando fui pela primeira vez a } \\
\text { uma biblioteca, eu tinha uns } 11 \text { anos. Desde então leio } \\
\text { bastante e compro muitos livros. Confesso que a chegada } \\
\text { de um notebook na minha vida diminui minha frequência } \\
\text { de livros lidos ao ano. }\end{array}$ \\
\hline Estado civil & Solteiro(a) \\
\hline Em que tipo de escola você estudou no ensino fundamental? & A maior parte em escola privada (particular) \\
\hline Em que tipo de escola você estudou no ensino médio? & Todo em escola privada (particular) \\
\hline $\begin{array}{l}\text { Você já cursou outra graduação anteriormente? } \\
\text { Caso tenha cursado outra graduação anteriormente e } \\
\text { concluído: Qual o curso e a instituição. Em que ano } \\
\text { concluiu? } \\
\text { Caso tenha cursado outra graduação anteriormente e não } \\
\text { concluído: Qual o curso e a instituição. Em que ano? Por } \\
\text { que não concluiu? }\end{array}$ & Não \\
\hline $\begin{array}{l}\text { Quantas pessoas da sua família moram com você? Considere } \\
\text { seus pais, irmãos, cônjuge, filhos e outros parentes que } \\
\text { moram na mesma casa com você. }\end{array}$ & 2 \\
\hline Qual o grau de escolarização dos seus pais? & Superior completo (mãe) Médio incompleto (pai) \\
\hline $\begin{array}{l}\text { Você exerce alguma atividade remunerada? } \\
\text { Em caso positivo, por quantas horas semanais? } \\
\text { Caso não exerça atividade remunerada, pretende começar a } \\
\text { exercer ainda este ano? Em caso positivo, quais seus planos } \\
\text { em termos de horas/modalidade (estágio, trabalho fixo, } \\
\text { trabalho eventual, etc. }\end{array}$ & $\begin{array}{l}\text { Não/ } \\
\text { Não pretendo }\end{array}$ \\
\hline
\end{tabular}




\begin{tabular}{|c|c|}
\hline \multicolumn{2}{|c|}{ PARTICIPANTE: ESTUDANTE I } \\
\hline QUESTÃO & RESPOSTA \\
\hline Idade & 18 \\
\hline $\begin{array}{l}\text { Conte como é sua relação com o circuito cultural da cidade } \\
\text { (shows, espetáculos, teatro, cinema, museus, etc.) }\end{array}$ & $\begin{array}{l}\text { Apesar de não ser algo constante, eu vou de vez em } \\
\text { quando ao Centro Cultural de São Paulo para shows, } \\
\text { exibições de filmes, visitar exposições e a biblioteca. Ao } \\
\text { cinema eu costumo ir de acordo com meu interesse em } \\
\text { algum filme específico. Apesar da baixa frequência, vou } \\
\text { em alguns musicais também. }\end{array}$ \\
\hline $\begin{array}{l}\text { Conte como é a sua relação, especificamente, com bibliotecas } \\
\text { (biblioteca escolar, pública, etc.) }\end{array}$ & $\begin{array}{l}\text { Durante minha formação escolar, não houve incentivo ao } \\
\text { uso da biblioteca - muitas vezes foi associada a um local } \\
\text { de acesso restrito (não podia ser usada durante o } \\
\text { intervalo e não era costumário frequenta-la após a aula) } \\
\text { ou de punição (alguns professores mandavam alunos que } \\
\text { não traziam o material pedido irem à biblioteca, para } \\
\text { fazer alguma pesquisa relativa a aula nos computadores). } \\
\text { Nunca foi associada a um local de pesquisa também - } \\
\text { isto é, ao pedirem certa leitura, os professores enviariam } \\
\text { o PDF do arquivo por e-mail ou indicariam páginas do } \\
\text { livro didático adquirido pelos alunos. } \\
\text { Quanto à biblioteca universitária, eu utilizo - a da ECA } \\
\text { principalmente - como local de leitura. Gosto de visitar } \\
\text { outras bibliotecas da USP para conhecê-las. O maior } \\
\text { proveito que eu tiro destas bibliotecas, no entanto, é o } \\
\text { SIBiUsp, para pesquisa e acesso a materiais digitais. } \\
\text { Não costumo frequentar bibliotecas públicas, com } \\
\text { exceção à biblioteca do Centro Cultural de São Paulo, } \\
\text { onde gosto de ver as exposições de arte, e eventualmente } \\
\text { utilizo para leitura de lazer. }\end{array}$ \\
\hline Conte sobre sua relação com a prática da leitura & $\begin{array}{l}\text { Além das leituras para as aulas, quando possível eu tento } \\
\text { ler algum livro por prazer/estudo pessoal. }\end{array}$ \\
\hline Estado civil & Solteiro(a) \\
\hline Em que tipo de escola você estudou no ensino fundamental? & Todo em escola privada (particular) \\
\hline Em que tipo de escola você estudou no ensino médio? & Parte no Brasil e parte no exterior \\
\hline
\end{tabular}




\begin{tabular}{|l|l|}
\hline $\begin{array}{l}\text { Você já cursou outra graduação anteriormente? } \\
\text { Caso tenha cursado outra graduação anteriormente e } \\
\text { concluído: Qual o curso e a instituição. Em que ano concluiu? } \\
\begin{array}{l}\text { Caso tenha cursado outra graduação anteriormente e não } \\
\text { concluído: Qual o curso e a instituição. Em que ano? Por que } \\
\text { não concluiu? }\end{array}\end{array}$ & \\
\hline $\begin{array}{l}\text { Quantas pessoas da sua família moram com você? Considere } \\
\text { seus pais, irmãos, cônjuge, filhos e outros parentes que moram } \\
\text { na mesma casa com você. }\end{array}$ & 2 \\
\hline \begin{tabular}{l} 
Qual o grau de escolarização dos seus pais? \\
\hline $\begin{array}{l}\text { Você exerce alguma atividade remunerada? } \\
\text { Em caso positivo, por quantas horas semanais? } \\
\text { Caso não exerça atividade remunerada, pretende começar a } \\
\text { exercer ainda este ano? Em caso positivo, quais seus planos } \\
\text { em termos de horas/modalidade (estágio, trabalho fixo, } \\
\text { trabalho eventual, etc. }\end{array}$
\end{tabular} & Não pretendo \\
\hline \begin{tabular}{l} 
Qual é, aproximadamente, a renda familiar mensal \\
\hline
\end{tabular} & Acima de 30 salários mínimos (mais de R\$29.940,01) \\
\hline
\end{tabular}




\begin{tabular}{|c|c|}
\hline \multicolumn{2}{|c|}{ PARTICIPANTE: ESTUDANTE K } \\
\hline QUESTÃO & RESPOSTA \\
\hline Idade & 19 \\
\hline $\begin{array}{l}\text { Conte como é sua relação com o circuito cultural da cidade } \\
\text { (shows, espetáculos, teatro, cinema, museus, etc.) }\end{array}$ & $\begin{array}{l}\text { Ocasionalmente vou ao cinema, com frequencia } \\
\text { aproximada de uma a três vezes a cada dois meses e não } \\
\text { tenho contato com outros espaços culturais por questões de } \\
\text { disponibilidade e financeira. }\end{array}$ \\
\hline $\begin{array}{l}\text { Conte como é a sua relação, especificamente, com } \\
\text { bibliotecas (biblioteca escolar, pública, etc.) }\end{array}$ & $\begin{array}{l}\text { No ensino fundamental e médio costumava frequentar as } \\
\text { bibliotecas escolares, porém somente neste ano tive } \\
\text { contato com bibliotecas públicas e } \\
\text { atualmente utilizo principalmente as da faculdade. }\end{array}$ \\
\hline Conte sobre sua relação com a prática da leitura & $\begin{array}{l}\text { Quando criança fui muito incentivada a praticar a leitura, } \\
\text { com isso fui desenvolvendo cada vez mais a vontade ler } \\
\text { livros diversos e isso se mantem até atualmente. }\end{array}$ \\
\hline Estado civil & Solteiro(a) \\
\hline Em que tipo de escola você estudou no ensino fundamental? & Todo em escola pública \\
\hline Em que tipo de escola você estudou no ensino médio? & Todo em escola pública \\
\hline $\begin{array}{l}\text { Você já cursou outra graduação anteriormente? } \\
\text { Caso tenha cursado outra graduação anteriormente e } \\
\text { concluído: Qual o curso e a instituição. Em que ano } \\
\text { concluiu? } \\
\text { Caso tenha cursado outra graduação anteriormente e não } \\
\text { concluído: Qual o curso e a instituição. Em que ano? Por } \\
\text { que não concluiu? }\end{array}$ & Não \\
\hline $\begin{array}{l}\text { Quantas pessoas da sua família moram com você? Considere } \\
\text { seus pais, irmãos, cônjuge, filhos e outros parentes que } \\
\text { moram na mesma casa com você. }\end{array}$ & 3 \\
\hline Qual o grau de escolarização dos seus pais? & Superior completo \\
\hline $\begin{array}{l}\text { Você exerce alguma atividade remunerada? } \\
\text { Em caso positivo, por quantas horas semanais? } \\
\text { Caso não exerça atividade remunerada, pretende começar a } \\
\text { exercer ainda este ano? Em caso positivo, quais seus planos } \\
\text { em termos de horas/modalidade (estágio, trabalho fixo, } \\
\text { trabalho eventual, etc. }\end{array}$ & $\begin{array}{l}\text { Não/ } \\
\text { Sim, estou em busca de um estágio. }\end{array}$ \\
\hline Qual é, aproximadamente, a renda familiar mensal & De 3 a 4,5 salários mínimos ( $\mathrm{R} \$ 2.994,01$ a $\mathrm{R} \$ 4.441,00)$ \\
\hline
\end{tabular}




\begin{tabular}{|c|c|}
\hline \multicolumn{2}{|c|}{ PARTICIPANTE: ESTUDANTE L } \\
\hline QUESTÃO & RESPOSTA \\
\hline Idade & 23 \\
\hline $\begin{array}{l}\text { Conte como é sua relação com o circuito cultural da cidade } \\
\text { (shows, espetáculos, teatro, cinema, museus, etc.) }\end{array}$ & $\begin{array}{l}\text { Minha relação com circuito cultural da cidade é estável. } \\
\text { Costumo frequentar cinemas no geral, e museus também. }\end{array}$ \\
\hline $\begin{array}{l}\text { Conte como é a sua relação, especificamente, com } \\
\text { bibliotecas (biblioteca escolar, pública, etc.) }\end{array}$ & $\begin{array}{l}\text { Minha relação com as bibliotecas sempre foi para o estudo, } \\
\text { um local no qual eu podia me concentrar e buscar as fontes } \\
\text { de pesquisa. }\end{array}$ \\
\hline Conte sobre sua relação com a prática da leitura & $\begin{array}{l}\text { Minha relação com a leitura sempre foi boa. Desde } \\
\text { pequeno esse é um hábito que procuro sempre estar } \\
\text { mantendo. }\end{array}$ \\
\hline Estado civil & Solteiro(a) \\
\hline Em que tipo de escola você estudou no ensino fundamental? & Todo em escola privada (particular) \\
\hline Em que tipo de escola você estudou no ensino médio? & Todo em escola privada (particular) \\
\hline $\begin{array}{l}\text { Você já cursou outra graduação anteriormente? } \\
\text { Caso tenha cursado outra graduação anteriormente e } \\
\text { concluído: Qual o curso e a instituição. Em que ano } \\
\text { concluiu? } \\
\text { Caso tenha cursado outra graduação anteriormente e não } \\
\text { concluído: Qual o curso e a instituição. Em que ano? Por } \\
\text { que não concluiu? }\end{array}$ & $\begin{array}{l}\text { Sim, mas não conclui / } \\
\text { Sistemas de Informação, FIAP em 2014. Não concluí o } \\
\text { curso pois não senti que combinava comigo e decidi } \\
\text { procurar algo mais interessante. }\end{array}$ \\
\hline $\begin{array}{l}\text { Quantas pessoas da sua família moram com você? Considere } \\
\text { seus pais, irmãos, cônjuge, filhos e outros parentes que } \\
\text { moram na mesma casa com você. }\end{array}$ & 1 \\
\hline Qual o grau de escolarização dos seus pais? & Superior completo \\
\hline $\begin{array}{l}\text { Você exerce alguma atividade remunerada? } \\
\text { Em caso positivo, por quantas horas semanais? } \\
\text { Caso não exerça atividade remunerada, pretende começar a } \\
\text { exercer ainda este ano? Em caso positivo, quais seus planos } \\
\text { em termos de horas/modalidade (estágio, trabalho fixo, } \\
\text { trabalho eventual, etc. }\end{array}$ & $\begin{array}{l}\text { Não/ } \\
\text { Para este ano, pretendo fazer iniciação científica, e, se } \\
\text { possível, começar um estágio. }\end{array}$ \\
\hline Qual é, aproximadamente, a renda familiar mensal & De 3 a 4,5 salários mínimos ( $\mathrm{R} \$ 2.994,01$ a $\mathrm{R} \$ 4.441,00)$ \\
\hline
\end{tabular}




\section{APÊNDICE C - REFERÊNCIAS DE ARTIGOS DO ENANCIB E DO SNBU, DE 2015 A 2019, QUE COMPUSERAM O CORPUS ANALÍTICO}

\section{ENANCIB}

2015

FRANÇA, Maira Nani; CARVALHO, Angela Maria Grossi de. Sociedade da informação e biblioteca universitária: contribuições para a democratização do acesso ao conhecimento. In: ENCONTRO NACIONAL DE PESQUISA EM CIÊNCIA DA INFORMAÇÃO, 16., 2015, João Pessoa. Anais... João Pessoa: UFPE, 2015.

MOREIRA, Luciana. Atuação de bibliotecários em bibliotecas universitárias brasileiras e portuguesas: espaço de mediação custodial ou pós-custodial? In: ENCONTRO NACIONAL DE PESQUISA EM CIÊNCIA DA INFORMAÇÃO, 16., 2015, João Pessoa. Anais... João Pessoa: UFPE, 2015.

2016

FREITAS, Livia Santos de; GOMES,Henriette Ferreira; SANTOS, Raquel do Rosário. Biblioteca universitária e o hábito informacional dos usuários: possíveis contribuições do bibliotecário na inserção do livro eletrônico na área de saúde. 2016. In: ENCONTRO NACIONAL DE PESQUISA EM CIÊNCIA DA INFORMAÇÃO, 17. 2016, Salvador. Anais... Salvador: UFBA, 2016. p. 2928-2949.

MATA, Marta Leandro da; ALCARÁ, Adriana Rosecler. Análise das práticas educacionais dos bibliotecários em bibliotecas universitárias com enfoque na educação de usuários e na competência em informação. 2016. In: ENCONTRO NACIONAL DE PESQUISA EM CIÊNCIA DA INFORMAÇÃO, 17., 2016, Salvador. Anais... Salvador: UFBA, 2016.

MAYRINCK, Marina; SOUZA, Elisabete Gonçalves de. Bibliotecas universitárias e ensino superior no Brasil (1980-1990). In: ENCONTRO NACIONAL DE PESQUISA EM CIÊNCIA DA INFORMAÇÃO, 17., 2016, Salvador. Anais... Salvador: UFBA, 2016.

PIZZORNO, Ana Claudia Philippi; DELFI, Elisa. Competência em informação digital: o ponto de vista dos bibliotecários gestores das bibliotecas universitárias da associação catarinense das fundações educacionais. In: ENCONTRO NACIONAL DE PESQUISA EM CIÊNCIA DA INFORMAÇÃO, 17., 2016, Salvador. Anais... Salvador: UFBA, 2016. 
SANTOS, Raquel Rosário; DUARTE, Emeide Nóbrega. Atividades de gestão nos dispositivos de comunicação da web social das bibliotecas universitárias brasileiras. In: ENCONTRO NACIONAL DE PESQUISA EM CIÊNCIA DA INFORMAÇÃO, 17., 2016, Salvador. Anais... Salvador: UFBA, 2016.

SATUR, Roberto Vilmar; SANTOS, Raquel do Rosário; SILVA, Alzira Karla Araújo da; DUARTE, Noadya Tamillys de Oliveira. O uso do facebook para a divulgação dos serviços das bibliotecas universitárias federais do nordeste. In: ENCONTRO NACIONAL DE PESQUISA EM CIÊNCIA DA INFORMAÇÃO, 17., 2016, Salvador. Anais... Salvador: UFBA, 2016.

SILVA FILHO, Rubens da Costa; MANGAN, Patrícia Kayser Vargas. Biblioteca universitária híbrida no contexto da web 2.0: integração de ferramentas para a promoção de produtos e serviços. In: ENCONTRO NACIONAL DE PESQUISA EM CIÊNCIA DA INFORMAÇÃO, 17., 2016, Salvador. Anais... Salvador: UFBA, 2016.

CAPELLO, Soraia Santana; CALIL JUNIOR, Alberto. Boas práticas no uso de mídias sociais em bibliotecas universitárias. In: ENCONTRO NACIONAL DE PESQUISA EM CIÊNCIA DA INFORMAÇÃO, 18., 2017, Marília. Anais... Marília: UNESP, 2017.

FRANÇA, Maira Nani; CARVALHO, Angela Maria Grossi de. Monitoramento de mídias sociais: um estudo exploratório em bibliotecas universitárias públicas federais. In: ENCONTRO NACIONAL DE PESQUISA EM CIÊNCIA DA INFORMAÇÃO, 18., 2017, Marília. Anais... Marília: UNESP, 2017.

MAYRINCK, Marina; SOUZA, Elisabete Gonçalves de. Universidade e biblioteca universitária no Brasil: o caso da biblioteca central do gragoatá da universidade federal fluminense. In: ENCONTRO NACIONAL DE PESQUISA EM CIÊNCIA DA INFORMAÇÃO, 18., 2017, Marília. Anais... Marília: UNESP, 2017.

PASSOS, Ketry Gorete Farias dos; VARVAKIS, Gregório Jean. O futuro da biblioteca universitária: tendências da revisão de literatura. In: ENCONTRO NACIONAL DE PESQUISA EM CIÊNCIA DA INFORMAÇÃO, 18., 2017, Marília. Anais... Marília: UNESP, 2017.

ZANINELLI, Thais. Inovação no contexto das bibliotecas universitárias: uma análise da evolução cultural no processo de desenvolvimento de serviços informacionais. In: ENCONTRO NACIONAL DE PESQUISA EM CIÊNCIA DA INFORMAÇÃO, 18., 2017, Marília. Anais... Marília: UNESP, 2017. 
COSTA, Maria Elizabeth de Oliveira; SANTA ANNA, Jorge; CENDÓN, Beatriz Valadares. Bibliotecas universitárias e a gestão da informação para o usuário das bibliotecas dos polos da educação a distância. In: ENCONTRO NACIONAL DE PESQUISA EM CIÊNCIA DA INFORMAÇÃO, 19., 2018, Londrina. Anais...Londrina: UEL, 2018.

GOMES, Thulio Pereira Dias; LARA, Marilda Lopes Ginez de. Práticas documentárias em bibliotecas universitárias: questões para o debate sobre políticas de informação. In: ENCONTRO NACIONAL DE PESQUISA EM CIÊNCIA DA INFORMAÇÃO, 19., 2018, Londrina. Anais...Londrina: UEL, 2018.

PINHEIRO, Alexandre Lobo; OLIVEIRA, Hamilton Vieira de. Tecnologia assistiva no processo de mediação da informação aos usuários com deficiência visual em biblioteca universitária. In: ENCONTRO NACIONAL DE PESQUISA EM CIÊNCIA DA INFORMAÇÃO, 19., 2018, Londrina. Anais...Londrina: UEL, 2018.

SILVA, Giordana Nascimento de Freitas e; COSTA,Maria de Fátima Oliveira. Estudos de usuários da informação na perspectiva de gestão: em foco a biblioteca universitária. In: ENCONTRO NACIONAL DE PESQUISA EM CIÊNCIA DA INFORMAÇÃO, 19., 2018, Londrina. Anais...Londrina: UEL, 2018.

SILVA, Sueli Alves; CAVALCANTE, Luciane de Fátima Beckman.Ações relacionadas à mediação explícita em biblioteca universitária. 2018. In: ENCONTRO NACIONAL DE PESQUISA EM CIÊNCIA DA INFORMAÇÃO, 19., 2018, Londrina. Anais...Londrina: UEL, 2018.

VIANA, Lilian; PIERUCCINI, Ivete. Informação e educação no ensino superior: a biblioteca universitária como espaço formativo. In: ENCONTRO NACIONAL DE PESQUISA EM CIÊNCIA DA INFORMAÇÃO, 19., 2018, Londrina.

Anais...Londrina: UEL, 2018.

ASCOLI, Arabelly; GALINDO, Marcos. Tendências para o futuro da biblioteca universitária pública brasileira. In: ENCONTRO NACIONAL DE PESQUISA EM CIÊNCIA DA INFORMAÇÃO, 20., 2019, Florianópolis. Anais...Florianópolis: UFSC, 2019.

BRESSANE, Julia Miranda; PINTO, Marli Dias de Souza. Gestão por competências na perspectiva da política nacional de desenvolvimento de pessoal: um estudo na biblioteca universitária da UFSC. In: ENCONTRO NACIONAL DE PESQUISA EM CIÊNCIA DA INFORMAÇÃO, 20., 2019, Florianópolis. Anais...Florianópolis: UFSC, 2019. 
CASSIAVILANI, Camila; OLIVEIRA, Maísa Maryelli de; AMARAL, Roniberto Morato do. Espaço coworking na biblioteca universitária: contribuições para a constituição da universidade empreendedora. In: ENCONTRO NACIONAL DE PESQUISA EM CIÊNCIA DA INFORMAÇÃO, 20., 2019, Florianópolis.

Anais...Florianópolis: UFSC, 2019.

Castro, Maria José Rodrigues de; VIEIRA, David Vernon. Ferramenta de gestão SWOT aplicada a biblioteca universitária da UFPI. In: ENCONTRO NACIONAL DE PESQUISA EM CIÊNCIA DA INFORMAÇÃO, 20., 2019, Florianópolis.

Anais...Florianópolis: UFSC, 2019.

CHAVES, Mayco Ferreira; FREITAS, Lídia Silva de. "A biblioteca deveria estar do nosso lado": com/sobre quilombolas e indígenas e suas relações com a biblioteca universitária. In: ENCONTRO NACIONAL DE PESQUISA EM CIÊNCIA DA INFORMAÇÃO, 20., 2019, Florianópolis. Anais...Florianópolis: UFSC, 2019.

DUTRA, Adlareg A. da C.; CARVALHO. Andréa V. de; SILVA, Antônia A. da; ALVES, Fernando Antonny Guerra; SILVA, Valéria Maria Lima da. Encontrabilidade da informação em biblioteca universitária: relato de auditoria na biblioteca central Zila Mamede. In: ENCONTRO NACIONAL DE PESQUISA EM CIÊNCIA DA INFORMAÇÃO, 20., 2019, Florianópolis. Anais...Florianópolis: UFSC, 2019.

KUSHNIR,Maria Rosa Carnicelli; PIERUCCINI, Ivete. Biblioteca universitária e formação cultural. In: ENCONTRO NACIONAL DE PESQUISA EM CIÊNCIA DA INFORMAÇÃO, 20., 2019, Florianópolis. Anais...Florianópolis: UFSC, 2019.

LEAL, Larissa Valeska do N.; NUNES, Martha Suzana Cabral. Design thinking: contribuições para o serviço de referência em bibliotecas universitárias. In:

ENCONTRO NACIONAL DE PESQUISA EM CIÊNCIA DA INFORMAÇÃO, 20., 2019, Florianópolis. Anais...Florianópolis: UFSC, 2019.

LIRA, Raquel Alexandre de; VARVAKIS, Gregório. Cocriação de valor em bibliotecas universitárias: evidências nas publicações científicas internacionais. In: ENCONTRO NACIONAL DE PESQUISA EM CIÊNCIA DA INFORMAÇÃO, 20. 2019, Florianópolis. Anais...Florianópolis: UFSC, 2019.

VIANA, Lilian; PIERUCCINI, Ivete. Biblioteca universitária e formação de produtores do conhecimento: mediações do patrimônio científico. In: ENCONTRO NACIONAL DE PESQUISA EM CIÊNCIA DA INFORMAÇÃO, 20., 2019, Florianópolis. Anais...Florianópolis: UFSC, 2019. 


\section{SNBU}

2016

DIMÁRIO, Clélia J. K.; FIGUEIREDO FILHO, Bernadete de L. da C. B.; BALDAN, Cibele C. D. et al. Relato da revitalização de uma biblioteca universitária. In: SEMINÁRIO NACIONAL DE BIBLIOTECAS UNIVERSITÁRIAS, 19., 2016, Manaus. Anais...Manaus: UFPA, 2016.

FRANÇA, Maira Nani; PORTELA, Patricia de Oliveira. Gestão compartilhada: avaliação e organização do trabalho pedagógico da biblioteca com base nos indicadores do MEC. In: SEMINÁRIO NACIONAL DE BIBLIOTECAS UNIVERSITÁRIAS, 19., 2016, Manaus. Anais...Manaus: UFPA, 2016.

PINHEIRO, Alejandro de Campos. Estudo dos usuários dos serviços de referência da Biblioteca Central da Universidade Federal do Triângulo Mineiro. In: SEMINÁRIO NACIONAL DE BIBLIOTECAS UNIVERSITÁRIAS, 19., 2016, Manaus. Anais...Manaus: UFPA, 2016.

RODRIGUES, Marcello M. Gestão do conhecimento e gestão do conhecimento científico em bibliotecas universitárias: uma revisão atual. In: SEMINÁRIO NACIONAL DE BIBLIOTECAS UNIVERSITÁRIAS, 19., 2016, Manaus. Anais...Manaus: UFPA, 2016.

SANTINI, Luciane A.; CASAGRANDE, Cledes A. A biblioteca enquanto espaçotempo de aprendizagens e de desenvolvimento de competências: o case de uma biblioteca do IFRS. In: SEMINÁRIO NACIONAL DE BIBLIOTECAS UNIVERSITÁRIAS, 19., 2016, Manaus. Anais...Manaus: UFPA, 2016.

SEGNORELLI, Maria Helena; Martins, Valéria S. G.; BRACCHI, Regiane A. Modelagem e implantação de programa de competência em informação. In: SEMINÁRIO NACIONAL DE BIBLIOTECAS UNIVERSITÁRIAS, 19., 2016, Manaus. Anais...Manaus: UFPA, 2016.

SOUTO, Clivea F. Biblioteca universitária: sua função social enquanto lugar de memória. In: SEMINÁRIO NACIONAL DE BIBLIOTECAS UNIVERSITÁRIAS, 19., 2016, Manaus. Anais...Manaus: UFPA, 2016.

2018

BAZILIO, Ana Paula; GOMES, Verônica de Souza. A mediação da informação e a aplicação das redes sociais pelas bibliotecas da Universidade Federal Fluminense. In: 
SEMINÁRIO NACIONAL DE BIBLIOTECAS UNIVERSITÁRIAS, 20., 2018, Salvador. Anais...Salvador: UFBA, 2018.

CARVALHO, Maria Gracilene de; LIMA, Gracirlei Maria de Carvalho.

Bibliotecário e a mediação da informação: serviços de referência do presencial ao virtual. In: SEMINÁRIO NACIONAL DE BIBLIOTECAS UNIVERSITÁRIAS, 20., 2018, Salvador. Anais...Salvador: UFBA, 2018.

FERREIRA, Kauane Lysien Costa. O papel da biblioteca virtual na mediação do ensino à distância. In: SEMINÁRIO NACIONAL DE BIBLIOTECAS UNIVERSITÁRIAS, 20., 2018, Salvador. Anais...Salvador: UFBA, 2018.

KAMA, Ana Flavia L. de F. ; SILVA, Fernando; SANTOS, Fabiana Camargo dos; CARMO, Rhuama Barbosa do. Clube de leitura da BCE: relato de uma ação cultural na Biblioteca Central de Brasília (BCE/UnB). In: SEMINÁRIO NACIONAL DE BIBLIOTECAS UNIVERSITÁRIAS, 20., 2018, Salvador. Anais...Salvador: UFBA, 2018.

Moraes, Juliana de Souza; CRISTIANINI, Glaucia Maria S.; MEDEIROS, Regina Célia V. Projeto biblioteca Viva: revendo os conceitos e renovando os espaços. In: SEMINÁRIO NACIONAL DE BIBLIOTECAS UNIVERSITÁRIAS, 20., 2018, Salvador. Anais...Salvador: UFBA, 2018.

RENAULT, Leonardo Vasconcelos; SANTOS, Fabiana Pereira dos. Biblioteca 24 horas: algumas reflexões e prospectos. In: SEMINÁRIO NACIONAL DE BIBLIOTECAS UNIVERSITÁRIAS, 20., 2018, Salvador. Anais...Salvador: UFBA, 2018.

SANTOS, Raquel Rosário dos; AMARAL, Louise A. F. de Oliveira do; Freitas, Livia Santos de. O uso dos dispositivos de comunicação da Web Social para a mediação da informação nos arquivos e nas bibliotecas. In: SEMINÁRIO NACIONAL DE BIBLIOTECAS UNIVERSITÁRIAS, 20., 2018, Salvador. Anais...Salvador: UFBA, 2018.

VIANA, Francisca das Chagas; DIAS, Neuda Fernandes. Inovação no sertão: a mediação cultural na biblioteca do Instituto Federal de Educação, Ciência e Tecnologia do Piauí - Campus Paulistana. In: SEMINÁRIO NACIONAL DE BIBLIOTECAS UNIVERSITÁRIAS, 20., 2018, Salvador. Anais...Salvador: UFBA, 2018. 